ENOTURISMO COLONIAL: ESTUDO DE CASO DAS PERSPECTIVAS DOS VITIVINICULTORES COLONIAIS DA REGIÃO DO VALE DOS VINHEDOS SOBRE A LEI DOS VINHOS COLONIAIS (LEI N ${ }^{\circ}$ 12.959/2014)

\author{
Universidade de Brasília -Centro de Excelência em Turismo \\ Mestrado Profissional em Turismo
}

Orientador: Prof. Dr. Mário Carlos Beni

Co-orientadora: Prof ${ }^{a}$. Dr ${ }^{\mathrm{a}}$. Marutschka Martini Moesch

Brasília - DF 
ENOTURISMO COLONIAL: ESTUDO DE CASO DAS PERSPECTIVAS DOS VITIVINICULTORES COLONIAIS DA REGIÃO DO VALE DOS VINHEDOS SOBRE A LEI DOS VINHOS COLONIAIS (LEI N ${ }^{\circ} 12.959 / 2014$ )

Trabalho apresentado junto ao Centro de Excelência em Turismo CET-UnB sob a área de concentração de desenvolvimento, políticas públicas e gestão no turismo, como requisito parcial para a obtenção do título de Mestre.

Orientador: Prof. Dr. Mario Carlos Beni

Co-orientadora: Profa. Dra. Marutschka Martini Moesch

Brasília 
Ficha catalográfica elaborada automaticamente, com os dados fornecidos pelo(a) autor(a)

BARBOSA RIBEIRO CECILIO DAHER, THIAGO GABRIEL ENOTURISMO COLONIAL: ESTUDO DE CASO DAS PERSPECTIVAS DOS VITIVINICULTORES COLONIAIS DA REGIÃO DO VALE DOS VINHEDOS SOBRE A LEI DOS VINHOS COLONIAIS (LEI N ${ }^{\circ} 12.959 / 2014$ ) / THIAGO GABRIEL BARBOSA RIBEIRO CECILIO DAHER; orientador MARIO BENI; co-orientador Marutschka Moesch. -- Brasilia, 2015 . $133 \mathrm{p}$.

Dissertação (Mestrado - Mestrado Profissional em Turismo) -- Universidade de Brasilia, 2015.

1. ENOTURISMO. 2. VINHOS COLONIAIS. 3. VALE DOS VINHEDOS. 4. PRODUÇÃO INFORMAL. I. BENI, MARIO, orient. II. Moesch, Marutschka, co-orient. III. Titulo. 
THIAGO GABRIEL BARBOSA RIBEIRO CECILIO DAHER

\title{
ENOTURISMO COLONIAL: ESTUDO DE CASO DAS PERSPECTIVAS DOS VITIVINICULTORES COLONIAIS DA REGIÃO DO VALE DOS VINHEDOS SOBRE A LEI DOS VINHOS COLONIAIS (LEI N $^{\circ}$ 12.959/2014)
}

\author{
Trabalho apresentado junto ao Centro de Excelência em \\ Turismo CET-UnB sob a área de concentração de \\ desenvolvimento, políticas públicas e gestão no turismo, como \\ requisito parcial para a obtenção do título de Mestre. \\ Orientador: Prof. Dr. Mario Carlos Beni \\ Co-orientadora: Profa. Dra. Marutschka Martini Moesch
}

BANCA EXAMINADORA

Professora Dra. Lana Magaly Pires

Professora Dra. Janaína Deane de Abreu Sá Diniz

Professor Dr. Mario Carlos Beni

Professor Dr. Luiz Carlos Spiller Pena

Brasília, 28 de julho de 2015 


\section{RESUMO}

A produção de suco de uva e vinho colonial na região do Vale dos Vinhedos é uma realidade não só dos tempos atuais, mas desde os tempos remotos de seus colonizadores. O vinho colonial sempre esteve presente na mesa e na história daquela população, até que no ano de 2014 uma lei federal foi elaborada com o intuito de regulamentar a produção e comercialização desse produto tradicional. A lei $\mathrm{n}^{\circ}$ 12.959/2014 ou lei dos vinhos coloniais, como é mais conhecida, foi aprovada com alguns vetos que culminaram na desaprovação por parte dos tradicionais vitivinicultores. O “enoturista-pesquisador” foi conhecer melhor quais são as opiniões e críticas dos produtores de vinhos coloniais sobre a lei que os "legalizam"; sobre o Vale dos Vinhedos e a relação que o enoturismo tem entre esses fatores. Houve a participação no " $2{ }^{\circ}$ Festival de Vinho Colonial - Vale dos Vinhedos" e foram feitas visitas e entrevistas a todos os vitivinicultores que estavam expondo no festival. As questões de pesquisa foram facilmente respondidas, uma vez que nenhum produtor da região aderiu ou tem intenção de aderir à lei, preferindo permanecer na condição de produção e comercialização informal. No entanto, com as visitas e conversas com os produtores foi possível vivenciar e analisar de uma maneira um pouco mais profunda do que realmente é o Vale dos Vinhedos sob a ótica diversa e única de cada produtor visitado.

Palavras-chave: enoturismo, vinhos coloniais, Vale dos Vinhedos, produção informal. 


\begin{abstract}
The production of grape juice and colonial wine in the region of Vale dos Vinhedos is not only a reality currently but it dates back all the way to the time of its colonizers. The colonial wine has always been present in the table and in the history of that populace, until the year of 2014 when a federal law was elaborated with the intent to regulate the production and commercialization of said traditional product. The law $n^{\circ} 12.595 / 2014$, or the colonial wine law, as it is most known, was implemented with some vetoes which resulted in the disapproval of traditional winemakers. The "researcher enotourist" went to take a better understanding of the opinions and critics from the colonial wine producers about the law that makes them legalized, about the Vale dos Vinhedos and the relation between the enotourism and these factors. There was in locale participation at the "Second Colonial Wine Festival - Vale dos Vinhedos" where interviews and visits were made to all winemakers that were exposing in the festival. The research questions were easily answered, one way that no region's producer join or intend to join the law, preferring to remain in an informal condition of production and marketing. However, it was during the visits and conversations with the makers that it was possible to deeply experience and analyze what really is the Vale dos Vinhedos under the unique scope of each maker visited.
\end{abstract}

Keywords: enotourism, colonial wines, Vale dos Vinhedos, informal production. 
SUMÁRIO

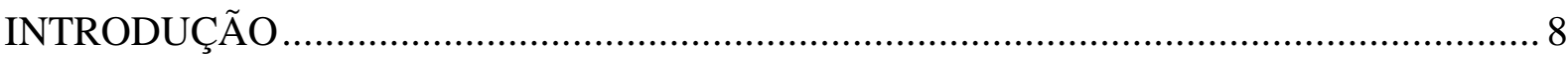

CAPITULO 1: FUNDAMENTAÇÃO TEÓRICA SOBRE O VINHO, O ENOTURISMO E O

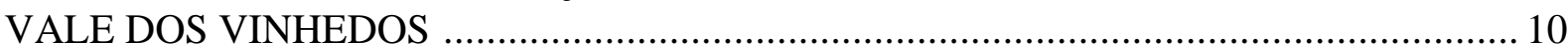

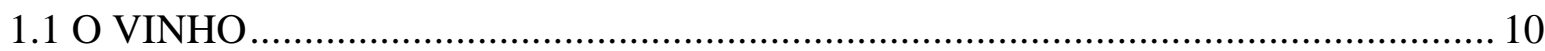

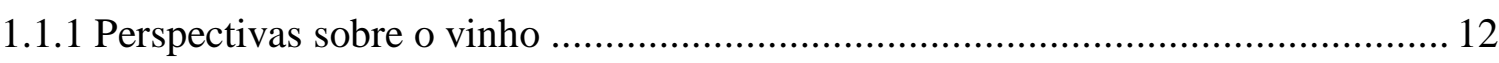

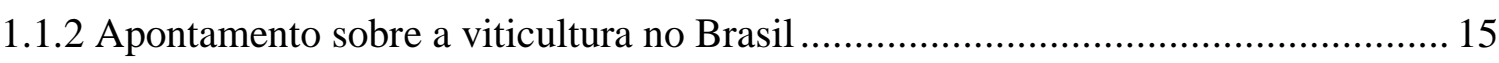

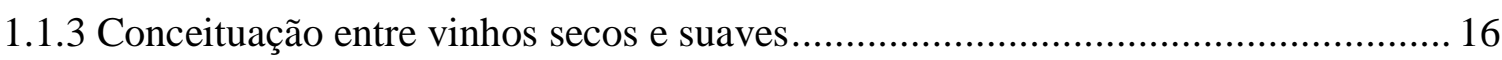

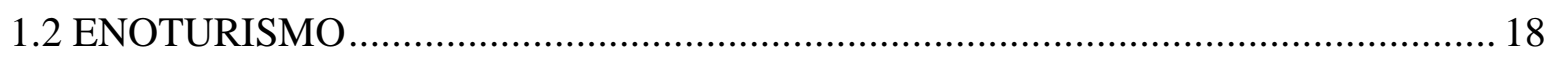

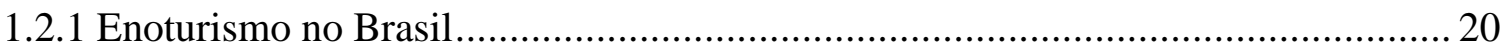

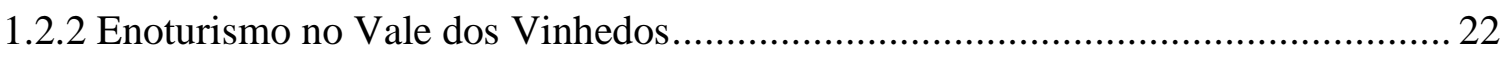

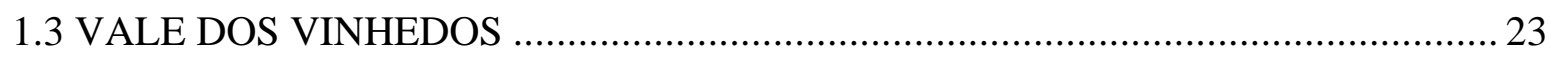

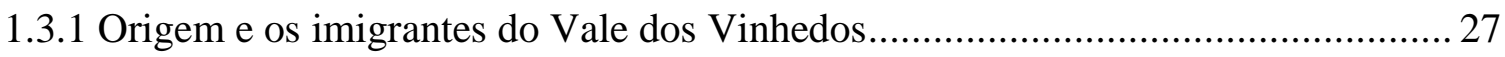

1.3.2 Terroir e indicação geográfica no Vale dos Vinhedos............................................ 31

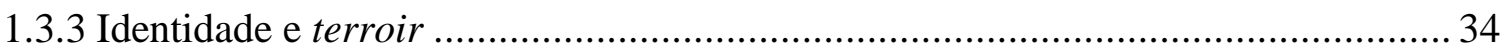

1.3.4 Festival Nacional do Vinho Colonial no Vale dos Vinhedos .................................... 41

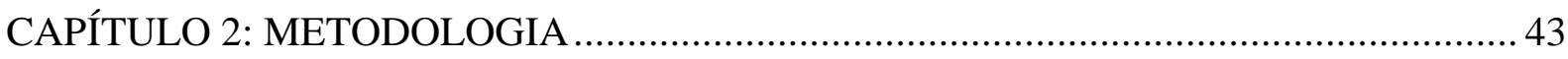

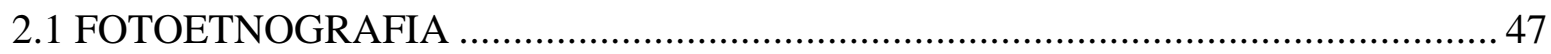

CAPÍTULO 3: ANÁLISE DO ESTUDO DE CASO OBSERVADO ................................... 49

3.1 FOTOETNOGRAFIA NO FESTIVAL NACIONAL DO VINHO COLONIAL .......... 49

3.2 DESCRIÇÃO DO $2^{\circ}$ FESTIVAL NACIONAL DO VINHO COLONIAL..................... 68

3.3 LEI DOS VINHOS ARTESANAIS: ANÁLISE DAS DIFERENÇAS ENTRE A PROPOSTA DE LEI E A LEI APROVADA, ANALISE DAS NOTAS DE VETOS DO

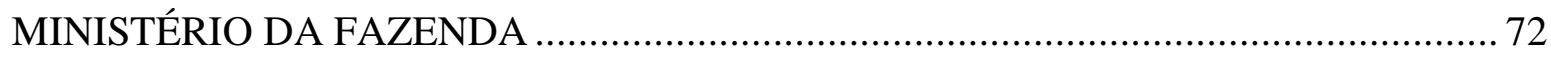

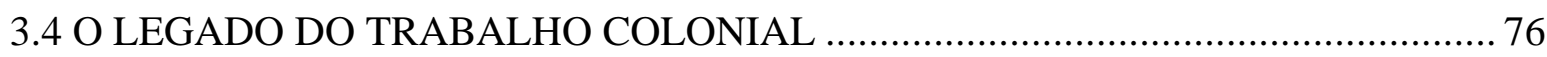

3.5 O TRABALHO DO COLONO COMO FORMA DE RESISTÊNCIA …………..........93

3.6 A LEI DOS VINHOS COLONIAIS, O ENOTURISMO E O VALE DOS VINHEDOS SOB A ÓTICA DOS PRODUTORES COLONIAIS ………..................................... 97

3.7 PARALELO ENTRE O LIVRO “COLONOS DO VINHO” DE JOSÉ VICENTE TAVARES DOS SANTOS E O OBSERVADO NAS VISITAS AOS PRODUTORES DE VINHO COLONIAL DA REGIÃO DO VALE DOS VINHEDOS ................................ 111

CAPÍTULO 4: CONSIDERAÇÕES FINAIS SOBRE A PESQUISA …………………….... 122

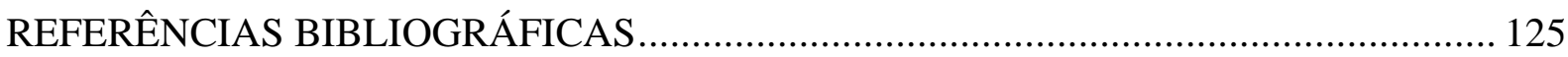

ANEXO A: LEI DO VINHO COLONIAL (LEI No 12.959 /2014)....................................... 130

ANEXO B: MENSAGEM DE VETO DADA À LEI .......................................................... 132 


\section{INTRODUÇÃO}

O Vale dos Vinhedos já é conhecido nacionalmente e internacionalmente pela produção de vinhos, ostentando a primeira indicação geográfica do Brasil. Sabe-se que a maior parte dos habitantes daquela região é de descendentes de imigrantes do norte da Itália, mais especificamente da região do Trento e Vêneto, que formaram colônias de imigrantes. A imigração italiana fez com que a região se tornasse uma pequena Itália, como afirmou a pesquisadora italiana Ornella Maiutto, fazendo com que muitas tradições e aspectos culturais italianos fossem replicados e preservados, com destaque para a produção de vinho.

O vinho para a população do Vale dos Vinhedos assume múltiplos signos e significações, desde o símbolo do sangue de Cristo, passando pela afirmação cultural dos imigrantes até como fator gerador de identidade local. Desta forma, cabe o questionamento sobre qual o tipo de vinho que os habitantes locais identificam como pertencente àquela cultura.

É possível identificar dois grandes grupos de vinhos na região. De um lado os vinhos finos produzidos a partir de uvas europeias pelas indústrias vinícolas, com selos de indicação geográfica e honrosos méritos do mundo enológico. Do outro lado, os vinhos coloniais, produzidos de maneira artesanal pelos agricultores e comercializados de maneira informal.

No ano de 2014 foi elaborada a Lei $n^{\circ}$ 12.959/14, mais conhecida como a lei dos vinhos coloniais, a qual conceitua e estabelece limites de produção e comercialização desses produtos e que já é uma realidade. No entanto, a lei foi aprovada com alguns vetos que a tornaram completamente desinteressante aos olhos dos agricultores, obrigando-os a permanecerem com sua produção e comercialização informal, da mesma forma que é feita há mais de 100 anos.

A produção do vinho colonial é realizada a priori para o consumo próprio, mas parte desse vinho é trocada, presenteada ou comercializada. A elaboração da lei do vinho colonial foi bastante oportuna para legalizar essas comercializações que já são realizadas de forma informal, onde o produtor vende diretamente para o consumidor final, sem nota fiscal, sem cobrança ou arrecadação de impostos e consequentemente ficando à margem da legislação tributária do país.

Coube ao pesquisador descobrir a opinião dos produtores tradicionais sobre as perspectivas de melhorias advindas da lei do vinho colonial na inclusão dos produtores coloniais na rota do turística do Vale dos Vinhedos; quais são os interesses dos produtores para a construção do enoturismo colonial na região e buscou conhecer também, quais seriam as 
expectativas referente ao vinho colonial, a região do Vale dos Vinhedos e o enoturismo na região. Tudo isso para analisar como a lei dos vinhos coloniais pode favorecer o enoturismo colonial e os pequenos produtores da região.

Atualmente o enoturismo é explorado na região principalmente pelas grandes indústrias vinícolas e pouco é feito pelo turismo realizado pelos produtores de vinhos coloniais. Algumas questões são pertinentes quando se conhece o Vale dos Vinhedos de uma forma um pouco mais profunda, que vai além dos castelos turísticos e visitas guiadas nas grandes indústrias vitivinícolas.

É intrigante conhecer como é a vida e os costumes daquela população, em sua maioria de viticultores, que moram ao lado das vinícolas. Como é a relação entre esses pequenos agricultores e as vinícolas? Qual é o vinho que está presente em suas mesas e que os habitantes do Vale dos Vinhedos se identificam? Qual a representação que o vinho colonial tem para eles? Quais as mudanças sentidas com a aprovação da lei do vinho Colonial? O fato de serem em sua maioria descendentes de italianos, qual a cultura que se identificam? Em suma, é inquietante a vontade de conhecer mais profundamente como os produtores e habitantes da região enxergam a realidade do Vale dos Vinhedos.

Além do interesse em conhecer melhor a região e a comunidade do Vale dos Vinhedos, a inquietação do autor sobre o tema foi fundamental para a escolha e delimitação da pesquisa, uma vez que trata-se de um assunto que transita por temas presentes no cenário brasileiro e que por muitas vezes, apresentam opiniões controversas como a intervenção do estado na produção de bens e serviços, incentivos à atenuação do êxodo rural, questões de ordem tributária e latifundiária, manutenção das tradições e formas alternativas de remuneração. Chegando até ao ponto de uma possível forma de produção de desobediência civil por parte dos agricultores. 


\section{CAPITULO 1: FUNDAMENTAÇÃO TEÓRICA SOBRE O VINHO, O ENOTURISMO E O VALE DOS VINHEDOS}

\subsection{O VINHO}

Antes de tratar sobre o histórico do vinho, é importante para uma compreensão de maneira complexa sobre o assunto que conhecermos alguns passos que precederam não só a produção de vinhos como a produção de uvas.

O cultivo da videira é de fato a base para a produção do vinho, mas muito antes do homem começar a lavrar e cultivar culturas agrícolas, as espécies vegetais já dominavam a face da terra com suas respectivas caraterísticas. Philips (2005) e Carraro (2008) citam que existe uma diferença de milhões de anos entre a existência das videiras e o seu cultivo agrícola.

Carlos Miguel Carraro (2008) descreve detalhadamente como acredita-se que ocorreu a formação da crosta terrestre e seus primeiros colonizadores, bactérias, fungos e posteriormente espécies vegetais. Segundo o autor, o ser humano surgiu no período Quaternário da Era Cenozoica, um período após a existência das plantas e incluído nesse grupo as videiras. Estudos arqueológicos indicam que já nesse período o homem consumia os frutos da videira. Esse fato é comprovado por estudos arqueológicos das populações pré-históricas, onde foram encontradas sementes de uvas juntamente com vestígios dessas populações.

Inicialmente as videiras se alastravam por toda a crosta terrestres com suas múltiplas variedades. No entanto, com o passar do período Glacial, quando a terra foi coberta por gelo quase totalmente, só houve três focos de resistência às intempéries que sobreviveram ao frio. Os focos de resistência foram encontrados na América, Europa e Ásia ocidental (Carraro, 2008). O foco americano originou as atuais espécies Vitis labrusca, Vitis rupestris, Vitis berlandieri, entre outras. O foco europeu, compreendendo as áreas mediterrâneas francesas e italianas, até a península balcânica, originou uma única espécie: a Vitis vinifera silvestris. O foco asiático-ocidental, localizado entre o mar Cáspio e o mar Negro, deu origem à Vitis vinifera Caucásicas. Essa região corresponde exatamente à região citada na Bíblia onde Noé, após o dilúvio, plantou e cultivou a primeira videira. (CARRARO, 2008, p. 23).

Passados alguns milhares de anos sob a dinâmica das videiras selvagens e do ser humano como coletor de frutas, infere-se que o homem começou a ter um papel mais dominante na relação de coleta e produção de alimentos quando iniciou o cultivo de algumas espécies vegetais. Souza (2005) cita que o homem primitivo era nômade e não era agricultor. Com o passar dos anos o homem passou a ter uma vida mais sedentária e o cultivo se fez necessário, 
estima-se que a agricultura surgiu na idade neolítica por volta de 6.000 a 4.000 a.C., já o cultivo da uva é mais recente, segundo o mesmo autor, estima-se que os primeiros ensaios com parreirais datam de 3.500 a 3.000 a.C.

Uma vez dominada a viticultura (cultura da vinha), o próximo passo para a produção de vinhos vem com os processos de vinicultura. Mesmo que de forma rudimentar, o processo de vinificação do sumo da uva é algo que tende a ocorrer naturalmente, uma vez que na própria uva já existem os insumos necessários para que o processo ocorra.

É muito difícil precisar quando e como foi o início da produção de vinhos, no entanto é possível inferir que a interação do homem com o vinho é uma relação de longa data. Existem indícios que estimam que a produção de vinho acompanha a humanidade desde a data de 4.000 a.C., quando existia a produção de uma suposta bebida alcóolica oriunda da fermentação de uvas (CEREJA, 2010).

No livro "Uma breve história do vinho" o autor Rod Phillips trata sobre as várias hipóteses dos primórdios da vitivinicultura no mundo. Consonantemente com a referência de Cereja (2010), Phillips (2005) cita que há indícios arqueológicos encontrados nas montanhas Zargos que datam de 5.400 a.C., onde foram achados jarros de barro que eram usados para armazenar líquidos tintos que seriam supostamente os primórdios dos vinhos.

No entanto, todas as afirmações sobre esse tema são apenas hipóteses. Duas hipóteses não muito consensuais sobre início da vitivinicultura, porém não menos interessantes é a "hipótese Noé" e a "hipótese do rei Jamsheed da Pérsia".

A hipótese de Noé como foi citada pelo autor Rod Phillips (2005) trata que segundo passagens do Antigo Testamento Noé foi o primeiro vitivinicultor, ao passo que cultivou a primeira parreira após o dilúvio, colheu seus frutos, produziu e bebeu vinho e ao final dançou nu dentro de sua tenda. Phillips (2005) cita indícios que essa primeira parreira plantada por Noé foi cultivada em Ararat, onde a arca atracou e segundo o autor, existe um elemento curioso nesta história, pois o monte Ararat fica próximo às montanhas Tauros do Leste da Turquia, onde crescem videiras silvestres e certamente o vinho era produzido naquela localidade nos tempos antigos.

Já a hipótese do rei Jamsheed da Pérsia apresenta de maneira casual, porém não menos possível que as demais hipóteses. Phillips (2005) explana que o rei Jamsheed da Pérsia apreciava comer uvas e as condicionava em potes de barro para mantê-las sadias por mais tempo. Ao abrir um dos potes de barros foi identificado que as uvas amadureceram antes do 
tempo e se liquefizeram, imediatamente colocaram aquele pote de lado e orientaram a todos que não consumissem aquele líquido pois poderia ser venenoso. Uma das mulheres do rei estava com fortes dores de cabeça e preferia morrer a continuar com aquelas dores e bebeu todo o líquido do pote. Dizem que ela adormeceu e quando acordou para surpresa de todos estava viva, sem dor de cabeça e muito alegre.

No entanto, independentemente de qual hipótese adotarmos como preferida, é sabido que o processo de transformação das uvas em vinho foi sendo desenvolvido por muitos anos até chegar as atuais técnicas enológicas e processos de vinificação.

Da mesma forma que os romanos foram os responsáveis pela disseminação da cultura da parreira por boa parte de seus territórios conquistados, foram eles que, segundo pesquisadores do assunto, desenvolveram as primeiras técnicas enológicas como a colheita tardia, onde a colheita era postergada ao máximo para que os frutos ficassem expostos ao sol por mais tempo, gerando a desidratação dos frutos e consequentemente maior concentração de açucares e vinhos mais alcoólicos. Foram os Romanos que desenvolveram alguns equipamentos de vinificação como a prensa e os toneis de madeira para melhor acondicionar as bebidas (CARRARO, 2008).

Já na idade moderna o vinho passou a influenciar vários artistas e estudiosos, e estes por sua vez passaram a influenciar nas formas de produção dos vinhos. Segundo Carraro (2008), as técnicas e materiais foram desenvolvidos cada vez mais para melhor beneficiar e prolongar a qualidade do vinho, e foi na idade moderna que a produção de vinho mais se aproximou das técnicas usadas na vinicultura atual com os estudos do cientista Luís Pasteur que, dentre outros títulos, recebeu o título de pai da enologia e nesta mesma época surgiu o uso de garrafas e rolhas de cortiça para acomodar os vinhos.

\subsubsection{Perspectivas sobre o vinho}

Não é objetivo deste trabalho exaurir as hipóteses ou precisar com exatidão onde e quando começou a relação do homem com o vinho. Sabe-se que o vinho é uma realidade da nossa sociedade e que os homens o produzem e bebem por diversos motivos. Transpondo a parte turva das definições de origens, trataremos um pouco não sobre o berço do vinho e da vitivinicultura, mas sim das perspectivas sobre esses temas.

Que o vinho pode ser encarado sob múltiplas respectivas isso é bastante razoável e aceitável pela maioria das pessoas. Fatores como educação, cultura, religião, hábitos 
alimentares, costumes, classe social, aptidão agrícola; todos esses fatores, e certamente seria possível elencar outros elementos que poderiam ter uma perspectiva diferente sobre o vinho e a viticultura, mas para isso ser feito, faz-se necessário um breve conhecimento sobre os caminhos oficiais e trilhas tortuosas que o vinho percorreu até chegar ao ponto que conhecemos hoje.

Uma visão bastante integradora é dada pelo autor Rod Phillips (2005) quando trata que o vinho é uma join venture entre o homem e a natureza, demostrando que cada participante desta associação é interdependente, onde os papeis são claros, no entanto, frequentemente um participante acaba por influenciar no trabalho do outro.

Para os religiosos cristãos o vinho representa o sangue de Cristo. A bebida que Jesus produziu a partir de água para animar uma festa de casamento, a bebida que Noé elaborou, bebeu e dançou. Para um religioso Islâmico o vinho alcoólico é proibido na vida terrena, mas é prometido em fartura na sua vida pós morte. Segundo Carraro (2008) foi durante a Idade Média que os padres desenvolveram os vinhedos e aperfeiçoaram técnicas enológicas. E foi a partir de então que a bebida foi incorporada ao simbolismo litúrgico e considerada sagrada para os cristãos.

Os vinhedos e as técnicas enológicas foram sendo desenvolvidas de tal forma nos ambientes religiosos que, segundo Soares (2004), alguns mosteiros ficaram famosos pelos vinhos que produziam. A autora cita que na região da Champagne e na região da Borgonha, foram os principais mosteiros conhecidos por seus vinhos. O pesquisador Vander Valduga (2007) confirma a citação da autora pontuando o mosteiro de Cluny na Borgonha que ainda é referência na atualidade.

Existia ainda uma relação de prioridade entre o consumo dos vinhos e os usos pelos religiosos. Os vinhos eram classificados em três categorias: os melhores vinhos eram reservados para o consumo dos próprios monges, já os vinhos de qualidade intermediária eram oferecidos aos nobres quando estavam hospedados nos mosteiros e os vinhos de qualidade inferior eram oferecidos aos peregrinos quando buscavam por abrigo. A autora cita que a bebida que era amplamente oferecida aos peregrinos era a cerveja, que também era produzida no mosteiro, mas o fato de oferecer vinhos aos peregrinos ocorria por uma questão de evitar maldisseres sobre a hospitalidade do mosteiro e para não se sentirem com dívida com o Divino, ao negar comida e bebida a um cristão. 
Uma outra perspectiva possível é quanto ao diferencial da questão de classe social ou cultural. É interessante observar que essa imagem vem sendo construída desde os tempos de ascensão do império romano.

Estudos indicam que o consumo do vinho era uma entre várias distinções estabelecidas entre os diferentes povos durante o Império Romano. Se por um lado os romanos acreditavam ser uma sociedade civilmente mais desenvolvida que os povos bárbaros, por seus costumes, hábitos alimentícios e religiosos e serem regidos sob o regime do império que durante algum tempo oferecia segurança contra as invasões bárbaras, os povos bárbaros tinham hábitos e dinâmica bastante distinta dos romanos. Juntamente com a expansão do Império Romano, os costumes e a produção de vinho foram desenvolvendo e expandindo. Segundo Phillips (2005), os romanos também tornaram o vinho uma forma de impor seus costumes e sua cultura. Expandiram o hábito de cultivar e beber vinho em todo o seu vasto império. Transformaram o vinho no principal produto do Império Romano e foram responsáveis pela fundação de grandes regiões vinícolas no mundo, até hoje famosas, principalmente na Itália, França e Alemanha.

No entanto, com a decadência do Império, os romanos começaram a conviver com outros povos e culturas. Alguns hábitos de consumo permaneceram evidentes e a produção e consumo de bebidas alcoólicas foi uma dessas diferenças, pois se por um lado os antigos pertencentes ao Império Romano estavam mais acostumados a cultura da videira, produção e consumo de vinhos; os povos bárbaros estavam mais acostumados a produção de grãos de inverno e produção de cervejas. Sendo assim, é possível inferir que a cerveja acabava por ser estigmatizada como uma bebida menos valorizada que o vinho naquela época.

Um outro fator que leva o vinho a ser caraterizado como uma bebida menos acessível é ao fato de a produção vinícola estar associada à colonização. A literatura sobre o tema cita que nos tempos do império Romano a cultura da videira foi distribuída por todos os territórios conquistados (CARRARO, 2008; PHILLIPS, 2005). Acrescentando ainda ao fragmento anterior, Miguel Carraro (2008) cita de a produção de uvas e vinhos estar intimamente ligada à colonização. $\mathrm{O}$ autor cita que os gregos desenvolveram a viticultura já existente no Egito e introduziram a cultura da uva no sul da Itália em 300 a.C.. No entanto, podemos notar que essa lógica do país colonizado replicar as culturas dos países colonizadores é bastante corriqueira.

É possível encontrar vários países que foram colonizados por países europeus e que acabaram replicando a cultura do vinho, desde que tenham as condições climáticas favoráveis, como é o caso do Uruguai, Argentina, Peru e Chile (colonização espanhola), África do Sul e Austrália (colonização britânica) e o próprio Brasil com sua colonização portuguesa que logo nos primeiros anos pós colonização já foram feitas tentativas de cultivo de vinhas no Brasil. 
Foi a partir da dinâmica das colonizações que o cultivo das videiras expandiu pelo continente Americano. A cultura do vinho foi desenvolvida principalmente entre os países latino americanos onde houve colonização espanhola como Peru, Chile e Argentina (PHILLIPS, 2003).

\subsubsection{Apontamento sobre a viticultura no Brasil}

Ao contrário do que muitos possam imaginar, a cultura da videira não teve seu início com os imigrantes italianos ou alemães. Inicialmente as primeiras videiras europeias a chegarem ao continente americano foram as vinhas trazidas por Cristovão Colombo em $1493 \mathrm{e}$ foram disseminadas principalmente pelo México e sul dos Estados Unidos (VALDUGA, 2007).

Alguns anos depois da chegada das videiras ao continente americano que os portugueses chegaram ao Brasil em 1500, mas as primeiras cepas cultivadas só foram plantadas em 1532. A expedição de Martin Afonso de Souza foi responsável por trazer agricultores da Ilha da Madeira e dos Açores, regiões de tradições vinícolas em Portugal para o território brasileiro.

Inicialmente, o primeiro produtor de uvas no Brasil foi Brás Cubas, que era proprietário de terras agrícolas e chegou a trazer seu pai e irmãos da região de Porto em Portugal para desenvolver o cultivo das videiras, que ocorreu primeiro no litoral paulista e posteriormente em na região de Tatuapé (VALDUGA, 2007; CARRARO, 2008).

Em 1551 a produção vinícola brasileira já conseguia suprir as demandas por vinhos brancos, que até então eram trazidos de Portugal. Os vinhos produzidos no Brasil eram oriundos principalmente das uvas brancas Malvasia e Verdelho, que eram tradicionalmente cultivadas em Portugal (CARRARO, 2008).

Muitos anos após a chegada das cepas portuguesas, a partir do ano de 1820, iniciou a imigração de italianos ao Brasil. Inicialmente parte dos primeiros imigrantes italianos permaneceram em São Paulo, de forma que já faziam alguns plantios de variedades italianas. No entanto, a vitivinicultura foi ganhando volume a partir do momento que houveram as posteriores imigrações italianas para os estados do sul e com a chegada de cem vitivinicultores franceses em 1865 no estado do Paraná (CARRARO, 2008).

Pesquisas indicam que o cultivo da uva no Estado do Rio Grande do Sul só foi ocorrer em 1626, com o Padre Argentino Beneditino Roque Gonçalves que trouxe mudas de videiras espanholas. No entanto, essa primeira tentativa no estado não foi exitosa. Novamente os portugueses trouxeram variedades portuguesas para o Brasil, só que no período de 1732 a 1773 
fizeram experimentos desde o litoral gaúcho até Porto Alegre. Algumas pesquisas citam que o clima litorâneo não favoreceu o desenvolvimento das videiras portuguesas pelo fato de não se acostumarem com as condições de baixa altitude e alta umidade. Já outros estudos apontam que não houveram incentivos nem técnicas adequadas para a produção das vinhas (DALCIN, 2008; VALDUGA, 2007).

Mesmo com várias tentativas frustradas da cultura da uva no Brasil, no ano de 1875 houve uma grande mudança. Essa data é marcada pelo início das grandes imigrações de italianos, em sua maioria do norte da Itália, para a região das colônias agrícolas, recém criadas, Dona Isabel e Conde $\mathrm{D}^{\prime} \mathrm{Eu}$, que posteriormente se tornaria a região das cidades de Bento Gonçalves, Garibaldi e Monte Belo do Sul. Segundo Maria Dalcin (2008), o berço da região do Vale dos Vinhedos ocorreu na colônia agrícola Dona Isabel. Com a imigração dos agricultores italianos para a atual região do Vale dos Vinhedos, a cultura da uva e do vinho se perpetua até hoje.

\subsubsection{Conceituação entre vinhos secos e suaves}

Para melhor compreender sobre a diferença entre os vinhos é importante esclarecer alguns pontos sobre a sua produção. Existe uma relação inversa entre a produtividade e concentração de açúcares e minerais na produção vitícola. Quanto mais uma videira produz, menos concentrado seus frutos estão com relação a carboidratos e minerais, ao passo que uma videira que tem sua produção conduzida a uma menor produção produz frutos com alta concentração de açucares e minerais. Desta forma, frutos com maior concentração de carboidratos e minerais tendem a gerar vinhos mais alcóolicos e complexos. Sabe-se que a conversão de açucares em álcool é uma reação que tende a ocorrer naturalmente, mesmo sem intervenção humana.

A diferença básica entre os vinhos secos ou suaves é com relação aos frutos que são oriundos e as técnicas enológicas aplicadas. Os vinhos secos são oriundos de frutos com alta concentração de açucares e minerais que permitem que a transformação de açúcar em álcool seja possível, denomina-se essa reação de "fermentação alcóolica". Estima-se que são necessários 17 gramas de açúcar para que haja a conversão em um grau alcoólico no vinho (ADEGABRASIL, 2011). Já os vinhos suaves, que são oriundos de frutas com baixa concentração de açúcares e minerais não possuem concentrações suficientes de carboidratos 
para fazer a fermentação alcóolica completa, necessitando de um adicional de carboidrato para concluir a reação satisfatoriamente.

Outro ponto que contribui para fortalecer a ideia sobre os vinhos coloniais serem oriundos de videiras américas, é o fato da videira americana produzir mais do que a videira europeia e assim ser possível fazer usos múltiplos das uvas como suco, consumo dos frutos, geleias e vinhos. Lembrando que quando os colonos chegaram no Brasil, eles enfrentaram uma situação de insegurança alimentar e por questões bastante compreensíveis davam atenção para a produção em quantidade.

Contribuindo com às informações apresentadas, Valduga (2008) afirma que a produção de vinhos simples pode ser até sete vezes maior que a produção de vinhos finos de maior valor agregado. $\mathrm{O}$ autor afirma ainda que as mudas plantadas pelos italianos foram obtidas pelos imigrantes alemães, pois parte das estacas trazidas secaram durante a viagem e outra parte não se adaptaram por serem estacas de mudas europeias (DE BONI; COSTA, 1979 apudVALDUGA, 2007). Sendo assim exposto, é possível inferir que tais mudas mais resistentes que os alemães trouxeram e se adaptaram com mais facilidade eram de videiras americanas, e foi com elas que os colonos produziam seus alimentos típicos.

É importante aferir alguns conceitos que serão adotados nesse trabalho. Usualmente adotamos o termo "viticultura" e suas variações, como a produção da cultura da vinha. "vitivinicultura" e suas variações, como a produção da cultura da uva para fins de produção de vinhos e o termo "vinicultura" e suas variações, como a produção de vinhos.

No entanto, o termo "enocultura", não muito usual, pode ser adotado como a relação entre o vinho e a cultura. O jornalista Renato Machado trata em seu livro "Em volta do vinho" que a importância atribuída ao vinho não é fruto da bebida em si, mas sim pela relação complexa e interdependente entre o vinho e tudo que o rodeia, sendo assim, o vinho acaba influenciando tudo que o rodeia e é igualmente influenciado por aquele todo.

Em conversa com o supervisor de varejo da Peter Longo, João Ferreira, na visita realizada no dia 15/04/2014, João afirma que "uma pessoa que consome vinho, bebe igualmente história". Já Roberto Rabachino afirma que "todos os vinhos merecem respeito, porque são fruto do trabalho dos humanos, punto!" (CONAVINHO, 2014).

Diante dessas três afirmações pode-se inferir que ainda assim é possível beber o vinho só por beber, ou com o objetivo de embriagar-se como é usualmente feito com outras bebidas. 
Mas se for feito desde modo, o "bebedor" não irá reconhecer e desfrutar das múltiplas faces e relações que o vinho carrega e pode oferecer, usufruindo somente de uma ou duas características do vinho, caracterizando assim, ao menos parcialmente, um desperdício do vinho.

\subsection{ENOTURISMO}

Inicialmente a palavra enoturismo nada mais é do que a junção do termo eno, do grego referente ao vinho, com o pós-fixo turismo. O estudo do enoturismo se mostra de forma bastante contraditória, pois como já foi abordado por vários autores da atualidade, trata-se de uma área de pesquisa e conhecimento muito recente, mesmo sendo a fusão de elementos com os quais o homem se relaciona desde longa data.

Por ser a fusão de dois elementos tão inconstantes e dinâmicos, é bastante compreensível que essa coalizão seja ainda mais dinâmica e mutante. Definir tal fenômeno é ao mesmo tempo trabalhoso e incerto pois o enoturismo, assim como todas as outras formas de turismo, é uma atividade que está intimamente relacionada com a experiência e sensibilidade individual.

Outro fator que demonstra como é difícil e incerto definir o fenômeno do enoturismo é embasado na citação das autoras Dallanhol e Tonini (20012) que afirmam que apesar dos estudos existentes, não se sabe com exatidão quando houve o início do enoturismo, o que é bastante razoável quando pensamos em atividades humanas que ocorrem naturalmente, sem marcos iniciais e finais, simplesmente acontecem.

No entanto para iniciar um trabalho científico, é usual fazer algumas definições sobre o assunto. É interessante observar que as definições já elaboradas seguem o mesmo princípio das diferentes sensibilidades individuais.

Algumas definições pautam a questão do vinho como ponto inicial, como é a definição de Falcade (2001) apud Valduga (2012), que define o enoturismo como "o deslocamento de pessoas, cuja motivação está relacionada ao mundo da uva e do vinho” (p. 128), já Valduga (2012) aponta outros agentes motivacionais para o enoturismo " $\mathrm{O}$ vinho e as pessoas que o produzem são os agentes motivacionais do enoturismo, visto que cada safra de uvas é diferente e não se podem ter vinhos iguais, pois ele possui as características de seu terroir" (p.128).

Por outro lado, existem também estudiosos que apontam que o enoturismo está igualmente relacionado com a experiência vivida. Segundo Hall (2004) apud Valduga (2012), 
“o enoturismo pode ser definido como visitações a vinhedos, vinícolas, festivais de vinhos e vivenciar na prática as características de uma região de uvas e vinhos”. Já Dallanhol e Tonini (2012) apostam numa visão mais ligada a sensibilidade do enoturismo caracterizando como "uma prática que une a degustação de vinhos ao conhecimento, à estada junto a belas paisagens e uma rica cultura que impulsiona muitas regiões do mundo" (p. 40). Charters e Ali-Knight (2002) apud Dallanhol (2012) acreditam que o enoturismo pode se relacionar com várias outras formas de turismo, como o turismo rural, cultural ou de aventura, dependendo dos paradigmas culturais e expectativas dos envolvidos.

No entanto, podemos ter algumas definições sobre o mesmo objeto, sob a égide econômica, como Dallanhol (2012) cita a caracterização dada pelo site departamento of state development de Queensland (2010):

Se o turismo é apenas a provisão de bens e serviços que atraem o turista, o turismo de vinhos é a mesma coisa, sofrendo influência do vinho. O enoturismo não está associado apenas com as vinícolas, mas também com todos os negócios envolvidos com o vinho, com o turismo e com as indústrias existentes na região vinícola. Isto inclui meios de hospedagem, guias, lojas de presentes, parques nacionais e etc. (QUEENSLAND, 2010 apud DALLANHOL, 2012, p. 44)

É possível observar que as definições sobre o enoturismo podem ser diversas dependendo do ponto de vista abordado. Cientes disso, uma delimitação sobre o objeto que aborda vários pontos de vistas é a definição elaborado pelo professor Vander Valduga onde afirma que:

Pode-se definir o enoturismo como um segmento do fenômeno turístico, que pressupõe deslocamento de pessoas, motivadas pelas propriedades organolépticas e por todo o contexto da degustação e elaboração de vinhos, bem como a apreciação das tradições, de cultura, gastronomia, das paisagens e tipicidades das regiões produtoras. É um fenômeno dotado de subjetividade, em que a principal substância é o encontro com quem produz uvas e vinhos. (VALDUGA, 2012, p. 130). 


\subsubsection{Enoturismo no Brasil}

É possível notar que o enoturismo está relacionado com regiões produtoras de vinho, o que podemos inferir que o enoturismo no Brasil é ainda mais recente. O pesquisador Jorge Tonietto (2005) identificou quatro períodos do vinho no Brasil. O primeiro período seria da implantação da viticultura e produção de vinhos de variedades americanas no período de 1870 até 1920. O segundo período, de 1930 até 1960, foi caracterizado pela introdução e produção de vinhos híbridos e de variedades europeias. Já o terceiro período, dos anos 70 até os 90, foi marcado pela necessidade que aumentar a qualidade e produção dos vinhos nacionais, já o quarto período que começa dos anos 2000 e vai até a atualidade, é demarcado pela busca por indicações geográficas para o fortalecimento da identidade dos vinhos brasileiros, tanto nacionalmente como internacionalmente.

Como a vitivinicultura brasileira apresenta-se em fase de desenvolvimento o enoturismo brasileiro apresenta-se igualmente em processo de estruturação e desenvolvimento se comparado com outros países de tradição vitivinícola. A produção de vinhos brasileiros se restringe a duas regiões, nordeste e sul.

A região nordeste brasileira, mais especificamente na região de Petrolina e Juazeiro nos estados de Pernambuco e Bahia, vem apresentando altas taxas crescimentos na fruticultura nacional. A vitivinicultura nordestina se desenvolve e apresenta crescente participação na produção de vinhos nacionais. A região destaca-se na produção de espumantes e apresenta a vantagem de ser a única região no mundo onde existe a possibilidade de produzir de duas a três safras por ano (DALLANHOL \& TONINI, 2012), ao passo que nas outras regiões do mundo só existe uma safra por ano. A produção vitivinícola no Nordeste apresenta outros fatores que favorecem o cultivo das videiras, uma vez que é uma região com altos índice de insolação, baixa pluviosidade, dias quentes e noites frias, solos arenosos e baixa ocorrência doenças de plantas.

Mesmo a região nordeste apresentando várias vantagens na produção de vinhos em relação a outras localidades no mundo, o enoturismo nordestino ainda está em desenvolvimento. Pelo fato da região nordeste não ter tradição vinícola, o enoturismo realizado na Rota do Vinho do Vale São Francisco aproxima-se da dinâmica do turismo realizado em países do novo mundo, como Austrália, Chile e Estados Unidos, onde as visitações tem maior ênfase para questões de produção e qualidade dos processos de vinificação e menor atenção para questões tradicionais. 
No entanto, o enoturismo no Brasil apresenta-se melhor estruturado nos estados do sul do pais, onde é possível encontrar diversas rotas turísticas de vinho como a rota do Vale dos Vinhedos; Vinhos de Montanha; Rota dos Espumantes; Vinhos dos Altos Montes; Rota do Vinho e Longevidade, no Rio Grande do Sul e já existe a Rota da Amizade e dos vinhos de Altitude em Santa Catarina (DALLANHOL \& TONINI, 2012).

O Estado do Rio Grande do Sul apresenta a vinicultura mais representativa no país por diversos fatores, principalmente pelas condições climáticas favoráveis ao cultivo de videiras para produção de vinhos, assim como pela forte influência dos imigrantes de países europeus, onde a vitivinicultura é tradicionalmente feita. Na rota do Vale dos Vinhedos é possível notar esses fatores se relacionando sinergicamente, onde o clima temperado da região montanhosa do nordeste gaúcho juntamente com seus habitantes, a maioria descendes de italianos, justificam o título informal de "mini Itália".

De forma análoga às fases da viticultura nacional apontado por Tonietto, o professor Vander Valduga descreveu as fases do desenvolvimento do enoturismo gaúcho da seguinte forma:

A FASE EMBRIONÁRIA, no período de 1930 a 1970, seria marcada pela $1^{\circ}$ Festa da Uva, em Caxias do Sul e a Festa Nacional do Vinho, em Bento Gonçalves e outros eventos onde seria possível dar notoriedade aos vinhos, como exposições agrícolas e pequenas feiras locais. Na FASE DE CRESCIMENTO consiste no aumento de exposições agroindustriais e festas regionais (Festa da Uva, Fenavinho e Festa Nacional do Champanhe) e organizações de jantares típicos nas cantinas familiares, além da criação da Associação de Produtores de Vinhos Finos do Vale dos Vinhedos (APROVALE), no período de 1970 a 1995. Já a FASE DE CONSOLIDAÇÃO, de 1995 até a atualidade, é o período onde são organizadas festas regionais tradicionais, as vinícolas passam a dar atenção ao atendimento turístico, surge a necessidade de capacitação profissional e desenvolvimento de certificações e identificação de produtos típicos das regiões vinícolas. É a partir dessa fase que surgem os primeiros estudos e pesquisas na área do turismo do vinho (VALDUGA,2012).

É oportuno observar que a fase de consolidação do enoturismo descrita por Valduga coincide com a quarta fase da vitivinicultura apontada por Tonietto (2005). É possível notar que ambas as fases almejam pela identificação regional. 


\subsubsection{Enoturismo no Vale dos Vinhedos}

A região do Vale dos Vinhedos atualmente é conhecida internacionalmente pela produção de vinhos e nacionalmente por ser o principal destino enoturístico em território brasileiro. No entanto, essas atividades são bastante recentes, conforme descrição de Valduga:

Os primeiros indícios do enoturismo na região surgiram nas décadas de 70 e 80 , quando algumas empresas familiares investiram na produção de vinhos finos. Esses vinhos finos eram comercializados nas próprias vinícolas, atraindo consumidores regionais, além de turistas que, nesse período, visitavam a vinícola Aurora, em Bento Gonçalves. A década de 90, no Vale dos Vinhedos, foi marcada pelo fortalecimento de vinícolas familiares. Muitas famílias produtoras de uvas deixaram de vender a produção para as grandes vinícolas e passaram a para fazer seu próprio vinho e comercializá-lo (VALDUGA, 2012, p. 134).

Conforme apontado por Valduga, a organização dos produtores foi fundamental para desenvolver o caráter enoturístico da região do Vale dos Vinhedos, desta forma a fundação da Associação dos Produtores de Vinhos Finos do Vale dos Vinhedos- Aprovale foi um marco na transição da fase de crescimento para a fase de consolidação.

A Associação dos Produtores de Vinhos Finos do Vale dos Vinhedos (Aprovale) foi formada em 1995, inicialmente por seis vinícolas com o intuito de atender as exigências legais para obter a Indicação Geográfica. Atualmente a Aprovale conta com 26 vinícolas e 43 empreendimentos de apoio associados (APROVALE, 2015).

Durante o período de atuação da Aprovale, o Vale dos Vinhedos obteve o registro de Indicação Geográfica, em 2002, e em 2012 foi aprovado o reconhecimento de Denominação de Origem. É importante atentar que tanto a registro de Indicação Geográfica, quanto a Denominação de Origem, foram registrados e reconhecidos pelo INPI- Instituto Nacional de Propriedade Industrial e esses registros foram obtidos através de uma ação conjunta entre a Embrapa, Ibravin- Instituto Brasileiro do Vinho, Universidade Caxias do Sul, Universidade Federal do Rio Grande do Sul, , ABE- Associação Brasileira de Enologia, SEBRAE- Serviço Brasileiro de Apoio às Micro e Pequenas Empresas, Aprovale, FINEP- Financiadora de Estudos e Projetos, INPI e todos os produtores envolvidos (EMBRAPA, 2015; APROVALE, 2015).

Os produtores do Vale dos Vinhedos tem o honroso mérito de ser a primeira região no Brasil a ter o registro de Denominação de Origem e posteriormente o registro mais restrito de Indicação de Procedência. No entanto, se por um lado esses títulos dão notoriedade, 
exclusividade e identificação aos seus produtos, por outro lado, a adoção desses registros restringem ou padronizam as formas de produção, como é o caso da Denominação de Origem do Vale dos Vinhedos que faz restrições de cultivares que são autorizadas, não constando nenhuma variedade das cultivares mais simples, que são amplamente cultivadas pelos agricultores coloniais.

\subsection{VALE DOS VINHEDOS}

Para que não haja confusão ao tratar sobre a região do Vale dos Vinhedos, é importante ressaltar que a denominação "Vale dos Vinhedos" possui duas especificações: a primeira e mais restrita, é adotada de forma político-administrativa ao distrito do Vale dos Vinhedos pertencente ao município de Bento Gonçalves. Já a outra denominação é atribuída à região do Vale dos Vinhedos, dotada de Indicações Geográfica e de Procedência, que é uma região pertencente a três municípios: Bento Gonçalves em sua maior parte, Garibaldi e Monte Belo do Sul (STEFANI, 2008).

A região do Vale dos Vinhedos está localizada na Serra Gaúcha, na porção da região denominada Encosta Superior do Nordeste do Rio Grande do Sul, entre as latitudes $29^{\circ} 08^{\prime} 15^{\prime}$ 'S e $29^{\circ} 14^{\prime} 26^{\prime \prime} \mathrm{S}$ e as longitudes $51^{\circ} 29^{\prime} 48^{\prime \prime} \mathrm{W}$ e $51^{\circ} 37^{\prime} 55^{\prime \prime} \mathrm{W}$, como mostra a figura 01 . Trata-se de uma região com clima classificado como subtropical com verão ameno. A estação climática de Bento Gonçalves aponta que as condições climáticas normais da região são de temperatura média anual de $17,2^{\circ} \mathrm{C}$. Janeiro é o mês mais quente, alcançando temperatura média de $21,8^{\circ} \mathrm{C}$, e junho o mais frio, com temperatura média de $12,8^{\circ} \mathrm{C}$. A precipitação total anual é de 1.736 mm, sendo maio o mês com menor precipitação acumulada (FLORES, 2012). 


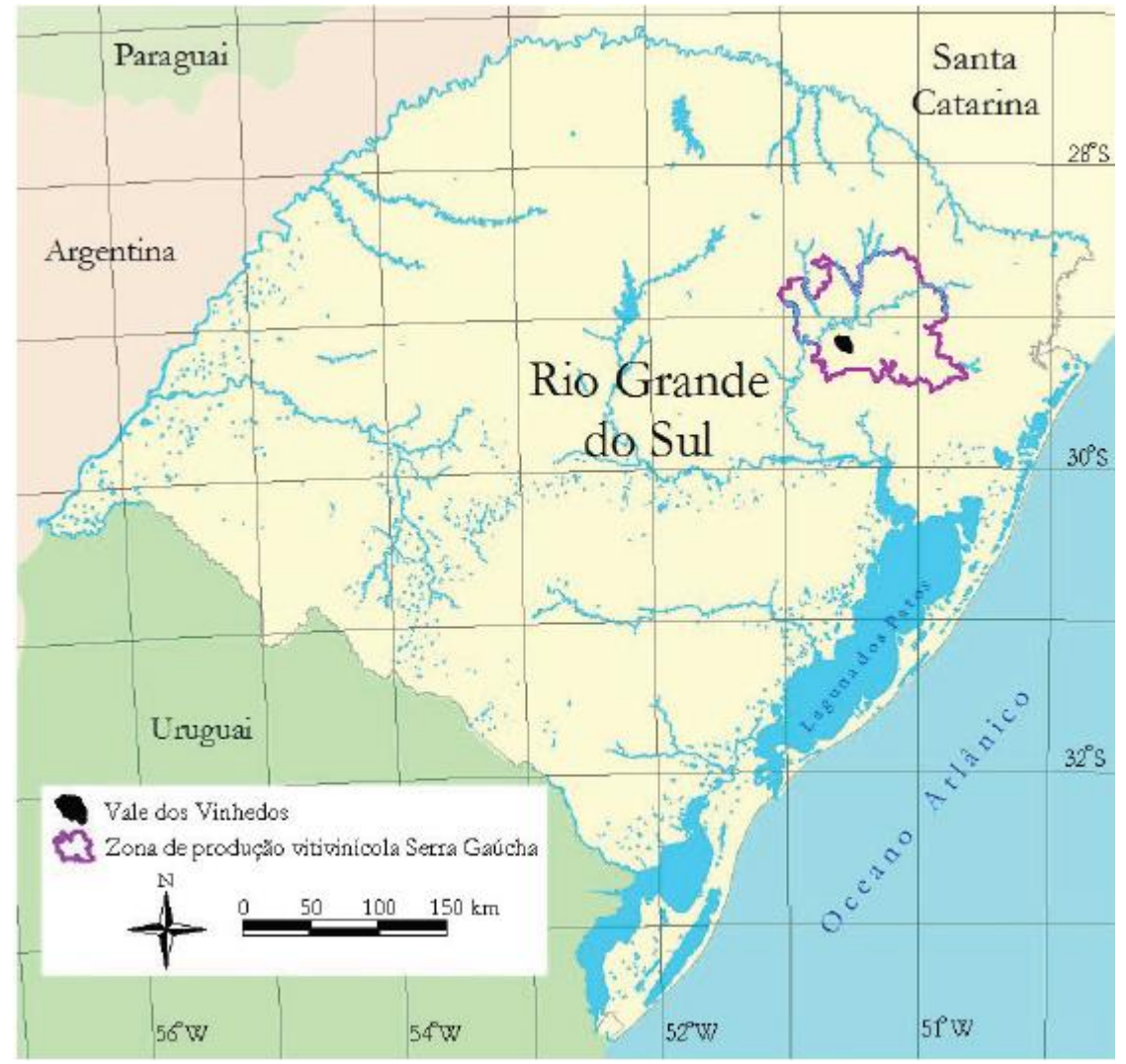

Figura 01: localização do Vale dos Vinhedos

Fonte: Os solos do Vale dos Vinhedos (FLORES, 2012, p. 20).

A topografia da região é ondulada no topo e as bordas são escarpada e recortada devido ao grande número de pequenos cursos d’água e intenso processo de drenagem. A região do Vale dos Vinhedos apresenta relevo complexo, com grandes variações de altitude, de declividade e de exposição solar (SARMENTO et al., 2006 apud FLORES, 2012).

Os solos de uma localidade são influenciados por vários fatores, principalmente pelas rochas de origem, relevo, temperatura e presença de água. No Vale dos Vinhedos não existe uma uniformidade dos solos devido às grandes variações de rochas de origem e relevo. Flores (2012) aponta que os solos das regiões vitivinícolas da Serra Gaúcha tendem a ser rasos e pedregosos, fato este que o autor pondera não ser um problema, pois mesmo com solos com pouca profundidade, estes apresentam fertilidade natural elevada e geralmente são cultivados com culturas diversificadas.

A vegetação original da região do Vale dos Vinhedos é caraterizada pela Floresta Estacional Decidual nas áreas escarpadas e Floresta Ombrófila mista, com bosques de araucárias intercalados com campos nos topos mais suaves. No entanto esses ecossistemas sofreram grandes mudanças antrópicas. Flores (2012) descreve que as mudanças causadas pelo 
homem ocorreram principalmente após o assentamento de imigrantes italianos que desmataram e queimaram as matas nativas para dar início à policultura tradicional e construir habitações.

Atualmente a região do Vale dos Vinhedos é caraterizada majoritariamente como área rural, com poucas áreas ainda florestadas e ainda com poucas áreas com transição urbana ou outros empreendimentos de caráter urbano.

Da mesma forma que as rochas originais se intemperizaram para formar os solos do Vale dos Vinhedos, a cultura italiana trazida pelos imigrantes foi lapidada e transformada para a atual cultura presente no Vale dos Vinhedos.

É notório como não só na área rural do Vale dos Vinhedos, mas como na área urbana de Bento Gonçalves, a cultura da produção vinícola, trazida pelos imigrantes, é um dos signos de identificação local. A foto 01 mostra uma parada de ônibus da área urbana de Bento Gonçalves, com o símbolo de um cacho de uva que aparenta representar um dos símbolos das raízes e cultura trazidas pelos imigrantes.

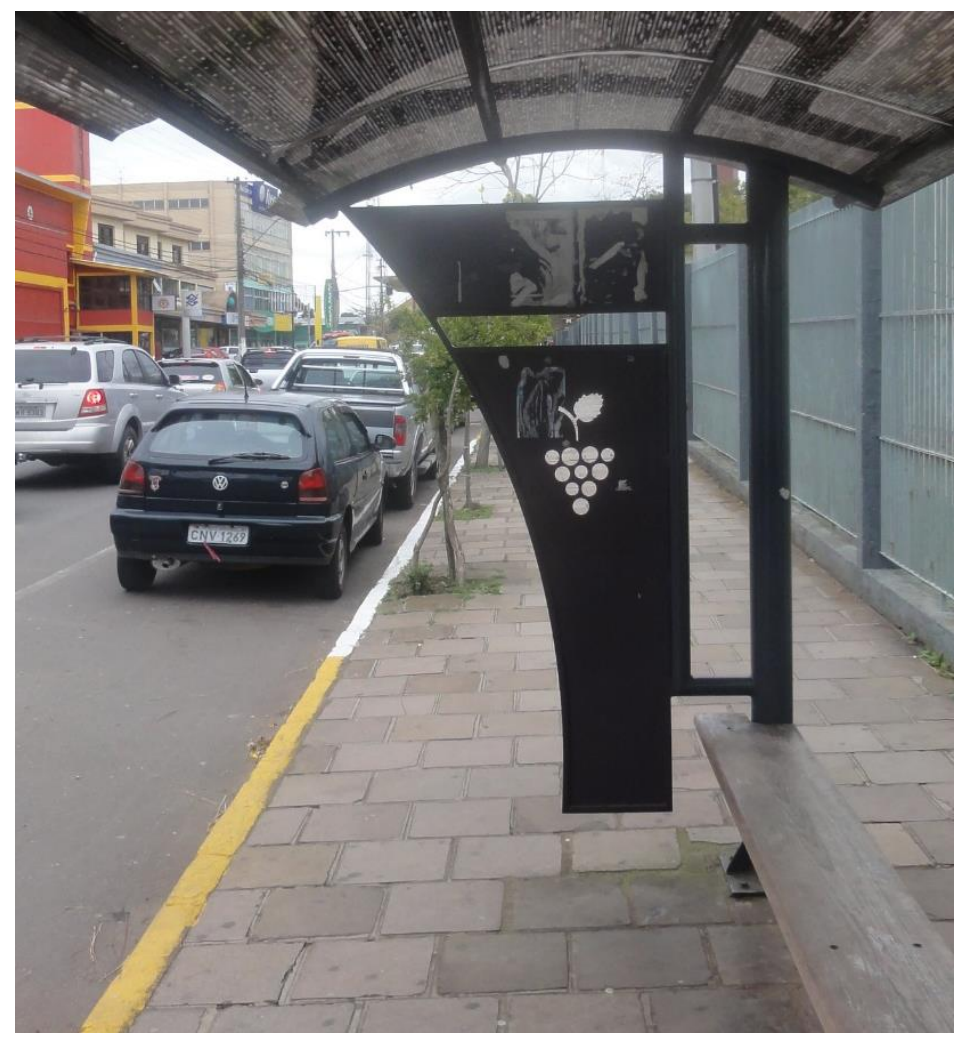

Foto 01: parada de ónibus com símbolo de uva.

Fonte: acervo do autor (2014)

Uma outra forma que seria possível encontrar o uso de signos de identificação da comunidade local é demonstrada claramente na constante ornamentação de vinícolas e casas com as bandeiras do Brasil e da Itália, como mostra a foto 02 no interior da vinícola Torcello. 


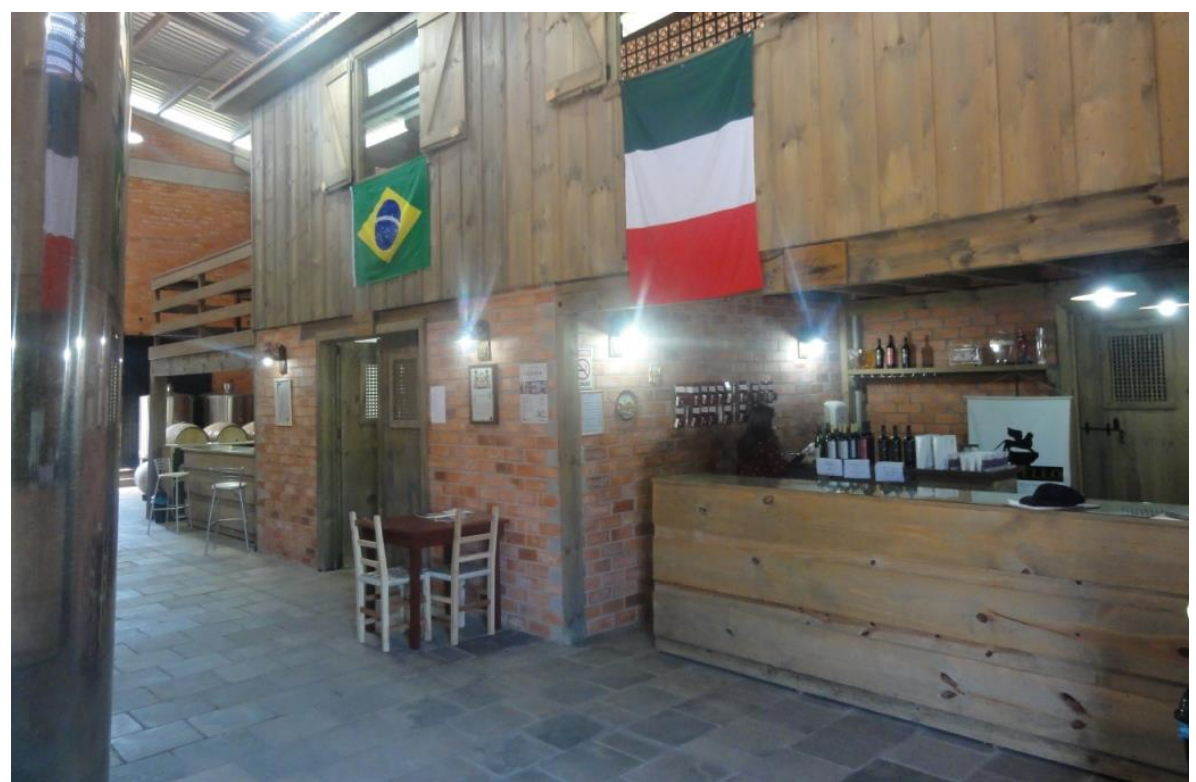

Foto 02: ornamentação em verde, amarelo, branco e vermelho.

Fonte: acervo do autor (2014)

Da mesma forma que é possível notar a forte relação Brasil-Itália com o uso de suas bandeiras, é possível reafirmar essa relação de demonstração da identificação ítalo-brasileira desta comunidade por meio do sotaque da população, assim como no sutil uso de roupas e adornos, como pode ser observado na foto 03 que evidencia senhores conversando na praça de Bento Gonçalves com roupas de inverno e boinas, típicas de países europeus, com o detalhe para a bandeira do Brasil no casaco do senhor sentado de boina escura.

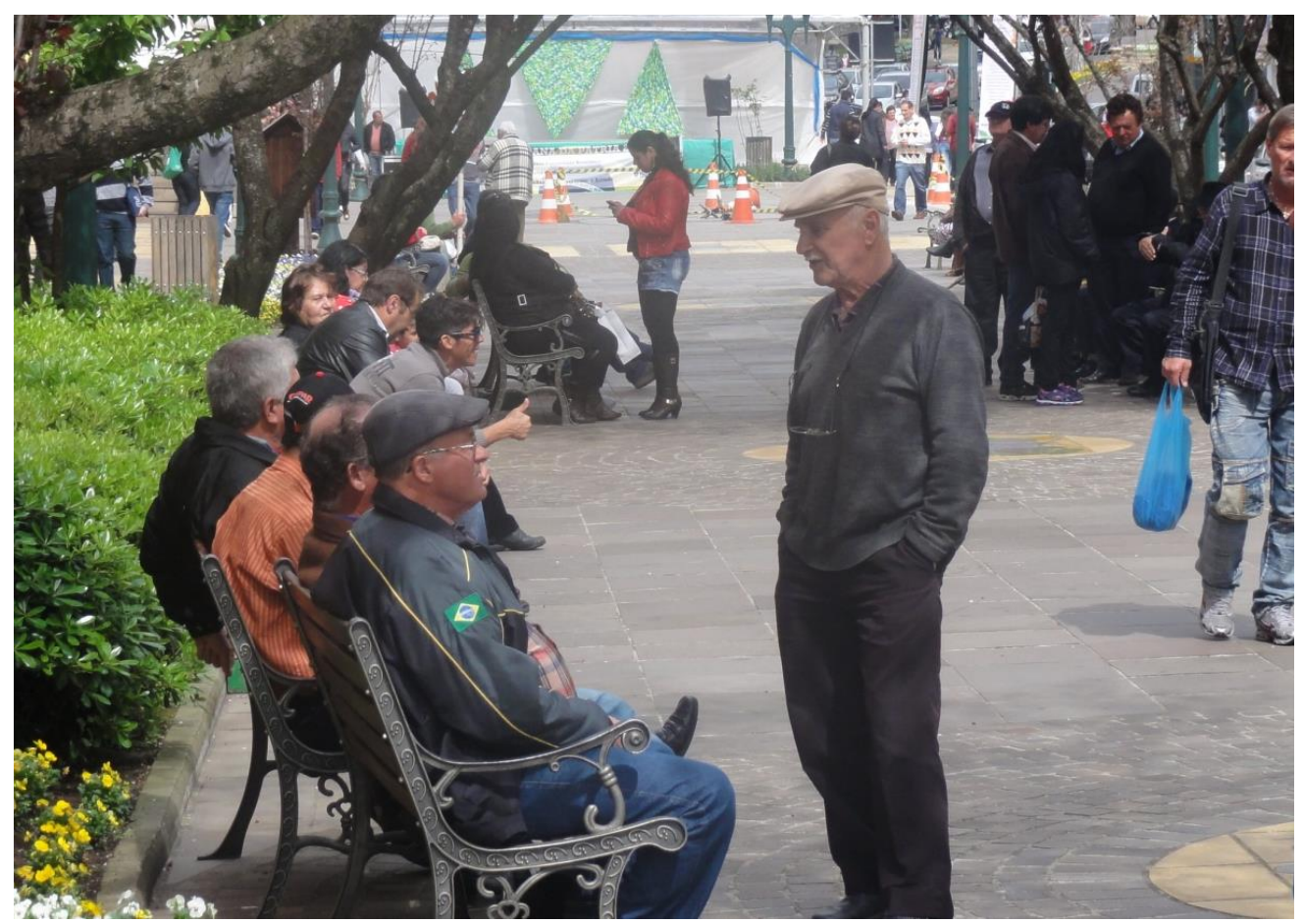

Foto 03: costumes ítalo-brasileiros.

Fonte: acervo do autor (2014) 


\subsubsection{Origem e os imigrantes do Vale dos Vinhedos}

Seria impossível falar sobre as origens do Vale dos Vinhedos sem falar nos imigrantes europeus. Houve uma expressiva imigração de povos europeus que firmaram morada principalmente nos estados do sul do Brasil como nas cidades portuárias. No entanto quando tratamos da região delimitada do Vale dos Vinhedos, existiu uma prevalência dos imigrantes italianos, em sua maioria da região de Vêneto, ao norte da Itália (TONINI; MACKE, 2007).

Muitos autores tratam sobre essa imigração, é possível inferir que as condições dadas às famílias migrantes eram precárias e difíceis, principalmente para crianças mais jovens e mulheres grávidas. As famílias italianas que migravam eram em sua maioria de lavradores e trabalhadores agrícolas com pouco estudo. Zanini (2007) relata que era uma população que habitualmente se vestia e comia mal e não possuíam nenhum prestígio no país que habitava, no entanto, esses trabalhadores acostumados a passar a tantas privações ouviam promessas de uma terra distante e que lá poderiam tornar-se signore- senhores, como um status de respeito e detentor de propriedades e negócios.

Eram famílias de origem rural, paternalistas e religiosas. Essas atribuições foram muito importantes para a tomada de decisão de vir para o Brasil. As famílias ouviam dizer que nessa nova terra seria possível vestir-se com seda e trabalhar pouco, fato este que seria praticamente inalcançável sob a realidade italiana e falta de oportunidades da época. Existia uma impulsão por parte dos homens em tentar a sorte e viver sob outro continente com maiores oportunidades, no entanto, as mulheres não estavam convencidas por esse discurso. Como já foi dito, tratavase de uma sociedade paternalista, onde muitas vezes os homens tomam as decisões e as mulheres eram submetidas às boas ou más decisões dos maridos. Como afirma Zanini (2007), a "autoridade paterna imperante naquelas famílias, a decisão final cabia idealmente ao homem, pai de família" (p. 526).

Um relato que evidencia essa relação assimétrica de tomadores de decisão foi dada por Pozzobon (1997) citado por Zanini (2007), onde afirma que "quantas mulheres com os cabelos desgrenhados increpam os maridos que quiseram dar aquele triste passo" (p. 527). Quanto ao incentivo religioso, a igreja católica teve papel importante na decisão da partida do continente europeu, as autoridades religiosas faziam relatos extremamente positivos sobre a América (ZANINI, 2007).

Uma vez que as famílias italianas chegaram às suas propriedades, elas se deparam com uma realidade bem diferente da qual imaginavam. Em conversa com um morador e trabalhador 
de um dos empreendimentos do Vale dos Vinhedos que prima pelo turismo histórico e cultural foi tratado a maneira como os "colonos" foram recepcionados. Segundo o interlocutor, os imigrantes italianos eram chamados de "colonos". Os imigrantes foram deixados em seus lotes depois de alguns dias de viagem de carro de boi. Ao chegarem em seus lotes, depararam-se com uma floresta densa com terreno acidentado, onde seria necessário ser feito primeiramente o desmatamento para poder cultivar a terra.

Esta densa floresta era formada por uma grande biodiversidade de plantas e animais, fato este que favoreceu a sobrevivência dessas famílias. As araucárias, segundo o interlocutor, tiveram importância ímpar na sobrevivência das famílias nos primeiros meses de habitação pois inicialmente não havia como plantar e pouco se caçava, ficando o pinhão como principal fonte de alimento. As figueiras ou Maria-mole como são conhecidas localmente, são árvores de tronco largo e fácil de ser trabalhada/cavada, foram usadas como abrigo inicialmente. Esses abrigos foram feitos ao perceber que os animais locais habitualmente faziam tocas dentro das árvores para se proteger das intempéries.

Houve também outras relações entre o homem e natureza, só que com a fauna local não foi uma relação tão amistosa. Inicialmente a região era habitada pela espécie Puma concolor, cujo o nome vulgar é Suçuarana ou como são conhecidas localmente por Puma ou Leão-baio. Conta-se que era muito frequente os embates entre homens e pumas, fato este que culminou em algumas mortes de pessoas e principalmente de crianças. Com o desmatamento, ou como é dito "abertura de terras", a caça aos grandes felinos e suas presas, resultou na extinção do puma nesta região.

É interessante notar que muitas das construções sociais que são feitas em relação à imagem negativa de determinados grupos sociais não são frutos de uma "maldade" dos indivíduos, e sim do ímpeto uno da sobrevivência. Esse interlocutor afirma que inicialmente os imigrantes italianos eram vistos como pessoas más, sem piedade e sem asseio com as vestimentas e habitações, pois matavam os pumas, comiam passarinhos e tinham dificuldades para suprir até mesmo suas necessidades mais básicas ou necessidades fisiológicas como alimentação, banho e abrigo.

Passada a fase inicial de descobrimento e estranhamento do novo continente, os italianos começam a trabalhar. $\mathrm{O}$ interlocutor trata que o incentivo para a emigração para o Brasil era dado principalmente para povos que teriam maior autonomia e que já fossem conhecidos pela 
capacidade de produção de suas próprias ferramentas e implementos, segundo o interlocutor, esses incentivos foram oferecidos principalmente para italianos, alemães e russos.

Na obra "Um olhar antropológico sobre fatos e memórias da imigração italiana" de Maria Catarina Chitolina Zanini, a autora acrescenta que os imigrantes italianos detentores de uma rara capacidade de trabalho e tenacidade, eram muito criativos e eram movidos por um espírito atávico e civilizador, sendo estes elementos incontestáveis no progresso dos países que os acolhiam. A autora afirma ainda que esses imigrantes saíram antes que a corrupção e descrença dos centros urbanos chegassem à região rural dos quais são oriundos, portanto é possível inferir que boa parte desses imigrantes vieram com o sentimento que seria possível fazer mudanças, e acreditavam no poder do trabalho em grupo.

É interessante salientar que o posicionamento dado por Zanini (2007) é muito próximo do conceito de "raça antropológica" adotado por Silvio Romero e posteriormente é criticado por Renato Ortiz (2006), onde a "raça antropológica" seria vinculada às questões biológicas, características e qualidades psicossociais natas de determinadas etnias. Durante muito tempo essa concepção determinística sobre os povos e etnias foi aceito pelos cientistas sociais, mas atualmente já caiu em desuso.

Desta maneira, é necessário se fazer uma ressalva quanto às atribuições dadas aos imigrantes italianos, quanto a suas capacidades "raras" de trabalho, espírito coletivo e religioso. Antes de qualquer adjetivo atribuído aos italianos, é importante lembrar que eram uma população de pessoas livres, diferente da força de trabalho usual dos escravos que havia no Brasil anteriormente. É bastante compreensível que o ímpeto que os levavam a trabalhar incessantemente, serem criativos e terem espírito coletivo é fruto principalmente do fato de serem oriundos de uma sociedade de pessoas livres e das condições que foram dadas a elas, e não de um atributo nato daqueles imigrantes.

Com relação à capacidade de trabalhar em grupo, ter espirito coletivo e fortalecer seu capital social, diversos autores tratam, mesmo que indiretamente, da relação gregária dos imigrantes italianos no Brasil. Como já foi dito anteriormente, os imigrantes vieram com suas famílias, que na sua maioria eram oriundas da parte rural da região norte da Itália, da região de Vêneto e sua organização era paternalista e religiosa.

A relação dos imigrantes com a religião era tão forte, que segundo De Boni (1980, apud ZANINI, 2007), não era o sentimento de pátria que fazia os imigrantes se unirem e sim a 
religião. Outros autores tratam da relação dos italianos com a capacidade de trabalhar em conjunto e favorecer o capital social dessas populações.

Sabe-se que existe uma região da Itália, que é conhecida como um dos mais bemsucedidos casos de arranjo produtivo local-APL, onde existe uma forte agregação/interdependência entre as empresas ali localizadas que confere numa considerável vantagem competitiva e desenvolvimento daquelas empresas e daquela região. Trata-se da região do norte da Itália, que é igualmente a da mesma região norte-italiana que os imigrantes italianos vieram.

As autoras Tonini e Macke (2007) em estudo sobre capital social citam um estudo realizado por Putnam (2002) na Itália onde trata sobre a capacidade de determinadas regiões italianas em trabalhar para fins coletivos. Nesse estudo, Putnam confluiu que das 20 regiões analisadas, a Calábria era a região menos "cívica", que possuía o menor número de associações, alto nível de desconfiança e maior nível de preocupação com os interesses individuais frente aos interesses coletivos. Nesse estudo o autor afirma que as regiões do norte da Itália são mais “cívicas" que as comunidades do sul, o que é evidenciado pelo fato de que desde o século XIX já haviam cooperativas formadas por viticultores daquela região.

Esse fragmento que trata sobre a capacidade do indivíduo em dar atenção às questões coletivas frente aos interesses individuais, é bastante pertinente à citação de Zanini (2007), quando a autora afirma que os imigrantes saíram da Itália antes de terem conhecimento dos casos de corrupção de descrença que já eram sentidas e conhecidas pelos italianos das capitais. Segundo essas duas linhas de pensamento, é possível inferir que os imigrantes italianos vieram já com um sentido de coletividade mais bem estruturado e que não havia sido "contaminado" com as ações e descrenças que enfraquecem o coletivo para favorecer um interesse individual. No entanto, não é objetivo deste trabalho afirmar que os imigrantes eram pessoas puras e livres do individualismo, mas que eram pessoas vindas de um contexto onde mesmo havendo pobreza da população, acreditava-se que ações reparatórias desta situação seriam mais exitosas se fossem oriundas de ações de origem coletiva que individual.

Seria possível sustentar a afirmativa anterior, conforme Soares (2004) trata que na chegada dos imigrantes, eles encontraram esperança e terras em abundancia, mas era necessário “começar tudo de novo". O autor cita ainda o caso da família de Amábile Baldissarelli Giordani, que havia ganhado um lote e que nunca havia tido uma propriedade com tal metragem e por isso optou por dividir a propriedade ao meio e comunicar ao governo que não achava justo ter 
tanta terra, dando de graça para outras pessoas que necessitavam de terras. Desta forma, essas terras dadas de "graça" deram origem à linha da Graciema. Segundo o autor, a palavra "Graciema" vem de "dada de graça", e que hoje é o nome de umas das principais áreas do Vale dos Vinhedos.

\subsubsection{Terroir e indicação geográfica no Vale dos Vinhedos}

A relação entre a procedência de bebidas e alimentos com uma noção de qualidade superior de tais produtos já é conhecida de longa data. Estima-se que na Grécia antiga já existia a atenção em adotar mecanismos para demarcar a procedências de seus produtos, como forma de inferir qualidade, principalmente no caso de vinhos. "Registros do século 7 a. C. comprovam que os gregos já identificavam os melhores vinhos com as respectivas denominações geográficas" (GLASS, 2009, p. 16).

Com o passar dos anos, diferentes localidades tornaram-se referência em determinadas atividades e produtos que produziam com qualidade superior às demais localidades. Quando ocorre de um produto apresentar qualidade e/ou tradição de determinado produto ou serviço podem ser atribuídos a sua origem, a Indicação Geográfica - IG surge como fator decisivo para garantir sua proteção e diferenciação no mercado (INPI, 2014).

No Brasil o registro de indicações geográficas foi formalizado pela Lei nº 9.279/LPI, na qual foi delegado ao Instituto Nacional de Propriedade Intelectual (INPI) a competência para estabelecer as condições de registro das indicações geográficas. Segundo a legislação vigente, as IGs podem ocorrer de duas formas: indicação de procedência ou denominação de origem. A Indicação Geográfica delimita a área de produção, restringindo seu uso aos produtores da região (em geral, reunidos em entidades representativas) e onde, mantendo os padrões locais, impede que outras pessoas utilizem o nome da região em produtos ou serviços indevidamente. A IG não tem prazo de validade. Com isso, o interesse nacional por esta certificação é cada vez maior.

Na Indicação de Procedência - IP pode ser dado o nome geográfico de país, cidade, região ou localidade de seu território, que se tenha tornado conhecido como centro de extração, produção ou fabricação de determinado produto ou de prestação de determinado serviço. Já na Denominação de Origem - DO é atribuído o nome geográfico de país, cidade, região ou localidade de seu território, que designe produto ou serviço cujas qualidades ou características 
se devam exclusiva ou essencialmente ao meio geográfico, incluídos fatores naturais e humanos (BRASIL, 1996).

No entanto, conforme afirma Trentini (2009), o legislador não foi inovador ao adotar essa classificação, a autora afirma que a conceituação estabelecida foi congruente com a elaborada pela Organização Mundial da Propriedade Industrial no acordo de Lisboa.

O Acordo de Lisboa, realizado em 1958, foi um dos diversos acordos multinacionais para firmar questões pendentes quanto à formalização de indicação geográfica. Embasou-se nos princípios das denominações de origens - appellations of origin estabelecidos pela Organização Internacional do Vinho - OIV, onde atribui a appellation of origin como o nome geográfico de um país, região ou localidade que serve para designar um produto originário de um determinado local, sua qualidade e características, as quais são, exclusiva e essencialmente, atribuídas ao meio ambiente geográfico, incluindo fatores humanos e naturais (GOLLO, 2006).

Com o intuito de objetivar, Flávia Trentini (2009) resume a função da indicação de procedência como uma forma de identificar e comprovar o território ou local onde o produto é oriundo. Não havendo a necessidade de inferir características específicas ou induzir a uma qualidade superior do produto. Resumidamente, “ é simplesmente uma informação ao público consumidor sobre a procedência do produto, aplicada a quaisquer produtos de um local geográfico" (p. 229).

No entanto, até o atual momento só tratamos das Indicações Geográficas sob a égide dos estudiosos de direito e legisladores, fazendo-se necessário adotar outras óticas sobre o mesmo objeto para ter uma melhor compreensão da complexidade do tema.

É consensual entre os pesquisadores do tema que as indicações geográficas são benéficas aos produtores rurais, principalmente para os pequenos, uma vez que estes não teriam condições de produzir em escala suficientemente grande para baixar os custos de produção individual de forma competitiva ao mercado. Desta forma, os produtores abrangidos por uma indicação geográfica podem dedicar mais atenção em produzir primando pela qualidade do produto ao invés de se preocupar com a quantidade produzida. Desta forma, é possível inferir que as indicações geográficas, não como fim, mas por consequência, tendem a gerar a agregação de valor ao produto, tornando-o diferenciado.

A agregação de valor aos produtos é uma das soluções para incluir, de forma competitiva no mercado, regiões com baixa escala de produção. As indicações geográficas beneficiariam a produção agrícola familiar, favorecendo agricultores 
que produzam em escala reduzida e, em alguns casos, também as famílias rurais à margem do mercado. (CHADDAD, 1996, apud GLASS (2009, p. 12).

É interessante notar que a complexidade das indicações geográficas chegam a transcender aspectos geográficos ou de processamento. Levando esse assunto sob a ótica da complexidade, pois tanto a Indicação de Procedência, mas principalmente Denominação de Origem levam em consideração o todo, o complexo, que é mais que o simples somatório das partes. Até porque, se houvesse, somente, o somatório das partes envolvidas sem suas relações de interdependência, certamente não teríamos o mesmo produto produzido sobre aquele cenário avaliado inicialmente. Ao mesmo tempo que as indicações geográficas levam em consideração aspectos da localidade, natureza, meio ambiente e clima da região, adota-se como variável igualmente importante o fator humano, o saber fazer - savoir faire, a forma e as relações de trabalho.

Da mesma forma que a conceituação sobre indicação geográfica é diversa, para o termo terroir não poderia ser diferente, sendo conceituado desde formas mais objetivas e resumidas, como versões mais completas. De maneira objetiva e prática seriam os atributos diferenciais que um vinho teria de um outro vinho com as mesmas características técnicas, mas que, no entanto, por diversos fatores, ou até mesmo um único fator pode gerar um produto, muitas vezes, completamente diferentes. É o diferencial de cada região. De forma um pouco mais reflexiva, poderíamos pensar no termo terroir como a materialização subjetiva da relação interdependente entre fatores técnicos, ambientais e humanos.

Podemos notar que a conceituação do termo francês dado por Tonietto (2007) é dado de tal forma que congrega tanto a parte técnica como é capaz de expor a complexidade e subjetividade que paira sobre o termo. O autor afirma que "o terroir é revelado, no vinho, pelo homem, pelo saber-fazer local. Se terroir inclui fatores naturais e humanos, ele não pode ser apropriado somente por um clima particular, ou um solo particular, por exemplo. O terroir é mais que isto". O autor prossegue ponderando que deve-se considerar o clima como um fator particular e que explique parcialmente o efeito terroir, mas é enfático quando afirma que "não existe terroir sem o homem".

Da mesma forma, o especialista em vinhos Roberto Rabachino conceitua o terroir como um espaço geográfico delimitado, onde uma comunidade humana construiu no curso da história o saber coletivo intelectual de produção. Em outras palavras, o especialista diz acreditar que o terroir é o conjunto de solo, clima, cepas, conhecimentos dos componentes, técnicas 
agronômicas e enológicas, o todo, que torna seu processo único e irreproduzível (CONAVINHO, 2014).

É oportuno notar a próxima relação entre os conceitos de terroir e Denominação de Origem. Ambos atribuem determinadas qualidades ou características exclusivas advindas das interações da tríade: restrição geográfica; fatores naturais e climáticos e aspectos humanos. De certa forma, não se trata de uma mera coincidência conceitual, pois Tonietto (2007) afirma que o termo terroir está inserido nos pilares da construção do conceito de denominação de origem. $\mathrm{O}$ autor faz algumas críticas ao uso banalizado do termo terroir nos países do novo mundo, pois é corriqueiramente usado com interesse comercial, induzindo a uma qualidade duvidosa dos vinhos.

Desta forma, seria interessante se pudéssemos fundir tanto a visão objetiva e nacionalmente aceita daqueles que tratam sobre as indicações geográficas com a visão subjetiva daqueles que tratam sobre o terroir. Assim seria possível inferir que a formalização de uma indicação geográfica do tipo denominação de origem adotada para regiões vinícolas seria como uma forma de legitimar o termo terroir de uma localidade. Sendo assegurado por lei a conformidade do uso do termo Denominação de Origem, nas entrelinhas terroir, de forma correta e justa para os seus merecedores e sem espaço para induções enganosas.

\subsubsection{Identidade e terroir}

A cultura da uva na região do Vale dos Vinhedos está intimamente relacionada com a cultura dos imigrantes italianos que colonizaram a região. Inicialmente o cultivo dos parreirais estava ligado à fixação desses grupos no país, de maneira que o cultivo da uva e o consumo do vinho representaram um vínculo com sua cultura e memórias do país de origem. A cultura da uva e do vinho nos tempos iniciais era basicamente uma técnica de cultivo e processamento que os imigrantes dominavam e vem sendo transmitida até os dias atuais entre as gerações como uma forma de reafirmar seus signos de identificação.

No livro "A identidade cultural da pós-modernidade", de Stuart Hall (2006), o autor aborda a ideia proposta por Mercer (1990) de que a questão da identidade somente se torna latente quando está em crise. A partir do momento que algo que se presumiria fixo e estável é modificado para uma situação com dúvidas e incertezas. No discorrer do livro, Hall trata da relação temporal e mutável da identidade, apontando que a identidade individual e cultural é tecida com o passar do tempo. $\mathrm{O}$ autor cita o caráter mutante e temporal da identidade a partir 
do momento que cita que não existe uma identidade fixa nas culturas modernas, apoiando-se na própria definição dada sobre sociedades modernas: "As sociedades modernas são, portanto, por definição, sociedade de mudança constante, rápida e permanente. Essa é a principal distinção entre as sociedades tradicionais e as modernas” (HALL, 2006, p. 14).

Stuart Hall trata também sobre as formas que a palavra "identidade" é usada. Uma vez ciente dos critérios da mutabilidade e transitoriedade das culturas modernas, o termo "identidade" corriqueiramente é visto como algo pronto, que foi construído com o passar dos anos, mas encontra-se acabado. $\mathrm{O}$ autor propõe que seria mais oportuno o uso do termo “identificação" por tratar-se de um termo de processo em andamento.

É interessante ponderar o quanto que os fatos passados influenciam os atos atuais e a cultura local. Autores como o próprio Stuart Hall e Lucília Neves Delgado ponderam sobre o tema da cultural local e fatos passados.

Com relação às características de identificação de um grupo e suas memórias, Lucilia Neves Delgado (2005) afirma que as lembranças e memórias de tempos passados são disseminados entre as gerações, de maneira que esse processo de recordar coletivo atua na forma de qualificar sua visão e maneira de vida e que passa a tendência ou mesmo determinar sua representação do presente. Partindo sob essa ótica da autora, é possível inferir que o modo de vida dos tempos passados influenciou os imigrantes, e esses por sua vez perpetuam essa reprodução de modos de vida nas próximas gerações e suas representações no presente, de forma a orientar seu estilo de vida e cultura na região atualmente.

Já Stuart Hall pondera que, da mesma forma que as características de identificação são constantemente feitas e refeitas através de processos inconscientes, há ainda a influência de fatos passados e fatos que os indivíduos não vivenciaram. É possível inferir pelas afirmações do autor que existe uma considerável margem de subjetividade para a adoção dessas características de identificação, pois segundo o autor, "existe sempre algo "imaginário" ou fantasiado sobre sua unidade", segundo ele, a identidade aparece não pela plenitude da identidade que está inerente ao indivíduo, mas pelos fragmentos vazios que são preenchidos a partir de nosso exterior, da maneira que acreditamos ser vistos pelos outros.

Desta forma, é possível inferir que parte das características de identificação é fruto daquilo que a pessoa ou o grupo gostaria de ser reconhecido, e não necessariamente daquilo que de fato é. 
Em estudo realizado por Lavandoski et al. (2012), as autoras abordaram de maneira bastante criteriosa a relação da cultura do vinho como forma sobrevivência e identificação da comunidade do Vale dos Vinhedos. Segundo as autoras, trata-se de uma região que vem se diferenciando das demais regiões turísticas graças às características que compõem o cenário da região vitivinícola que foi colonizada por imigrantes italianos e que deixa à mostra a cultura do povo que a colonizou (LAVANDOSKI et al., 2012).

A vitivinicultura foi um importante meio de sustento das famílias de imigrantes italianos e também uma maneira de desenvolver e promover o crescimento econômico da região e, que na atualidade, a uva e o vinho são elementos de identificação cultural da comunidade perante turistas e visitantes. (LAVANDOSKI et al., 2012, p. 216).

Sendo assim, é possível inferir que parte da identificação daquela localidade está sendo construída com base nas histórias contadas pelos mais velhos, pelo trabalho que se dedicam atualmente, pelas características distintivas que sentem que tem em relação aos outros e algumas outras características que gostariam de ser reconhecidos.

O termo terroir oriundo da língua francesa, já foi traduzido com o significado de território ou territorialidade. Entretanto, o próprio dicionário compacto Le Nouveau Petit Robert, denomina terroir como uma porção limitada de terra considerada do ponto de vista de suas aptidões agrícolas. A consulta ao dicionário, não tem interesse acadêmico à priori, é somente para evidenciar que mesmo obras de literatura que prezam pela objetividade não traduzem o termo a simples palavras, ou desconsideram seu contexto usual.

Sendo assim, existem autores que adotam visões sobre o mesmo objeto sobre diferentes perspectivas. Existem alguns que abordam o viés do terroir mais relacionado às questões humanas, como é o caso da interpretação dada por Barham (2003) que adota o termo relacionando à interação social envolvida pelos produtores e a região, formas e modos tradicionalmente feitos na produção. A autora afirma ainda que seria uma forma de dar a signature, isto é, a assinatura do seu estilo de vinificação ao seu produto. Concordando em parte com a ideia de Barham, anteriormente citada, Tonietto (2007, p. 02) afirma que "não existe terroir sem o homem". Mas vai além da visão focada em fatores humanos. O autor discorre que o terroir é a interação entre a natureza (meio natural) e fatores humanos. Não abrangendo somente aspectos técnicos naturais (clima, solo, relevo, insolação), mas de maneira sinérgica, os fatores humanos da produção, incluindo a escolha das variedades, aspectos agronômicos e formas de elaboração do produto. $\mathrm{O}$ autor resume ainda que: 
Na verdade, o terroir é revelado, no vinho, pelo homem, pelo saber-fazer local. O terroir através dos vinhos se opõe a tudo o que é uniformização, padronização, estandardização e é convergente ao natural, ao que tem origem, ao que é original, ao típico, ao que tem caráter distintivo e ao que é característico (TONIETTO, 2007, p. 1).

Da mesma forma que Tonietto atribui o saber fazer local às características do terroir, Philippe Drugeon (2009) afirma que o savoir-faire na produção vinícola são todas as competências/capacidades advindas da experiência, mas poderiam ser igualmente ensinadas em um curso técnico de vinificação. É, portanto, a capacidade de tanto racionalizar, sentir, ver o que está sendo feito e conseguir “prever” os frutos dessas ações (DRUGEON, 2009). No entanto devemos observar que tal afirmação de Drugeon se restringe somente ao "saber-fazer" e não ao conceito de terroir, desta forma é razoável pensarmos que o conhecimento para determinadas ações e intervenções humanas na vinificação possa ter também esse caráter técnico e objetivo.

Os símbolos que conferem identificação a determinados grupos são múltiplos em formatos e meios, podendo ser desde bandeiras, hinos, danças, armas e até mesmo bebidas e alimentos. A historiadora e arqueóloga Marina Regis Cavicchioli descreve em seu artigo "O terroir e a identidade cultural" que:

o motivo pelo qual podemos compreender o tratamento dado pela resistência francesa aos vinhos durante a Segunda Guerra Mundial. As garrafas foram um tesouro bem protegido e escondido dos alemães. Obviamente o sentido de preservação não consistia apenas em conservar um bem material, mas o símbolo de uma identidade, de um orgulho nacional. Não o entregar era, em certa medida, poupar a própria alma dos franceses, ou ao menos daqueles grupos que se vinculavam culturalmente aos terroirs (CAVIOCCHIOLI, 2006).

Corroborando com a afirmação de Cavivhioli, o professor Vander Valduga descreve que o vinho está numa categoria simbólica diferente da maioria dos bens de consumo, pois é um produto que contém uma "embalagem cultural dotada de uma carga simbólica, características que dificilmente poderia ser percebidos e agregados a outros produtos". (VALDUGA, 2008, p. 07).

É possível notar que existe uma íntima relação entre o conceito de terroir e identidade. Mas essa identidade seria somente a identidade atribuída ao produto, como a "assinatura" 
descrita por Elizabeth Barham (2003), ou seria no sentido de afirmação de identidade dos produtores, com suas tradições, maneiras e estilos de vida, como apontado por Lucilia Neves Delgado (2005)?

Apesar das duas autoras analisarem objetos diferentes, seria difícil colocá-los em choque, pois os discursos de ambas são consonantes, como trataremos adiante. É igualmente importante tratar sobre as relações entre a formação da identidade e a noção de terroir, pois da mesma forma que Tonietto (2007) descreve sobre o terroir, Lavandoski et al.(2012) descrevem sobre a formação e manutenção da identidade da população do Vale dos Vinhedos.

\begin{abstract}
Pode-se afirmar que a identidade é contrária e resiste ao processo de homogeneização produzido pela globalização, visto que está alicerçada nas diferenças e particularidades das culturas locais. Para que uma região construa uma identidade, é fundamental que se volte para o passado, dando ênfase à aceitação coletiva dos mais diferentes aspectos existentes na mesma. (LAVANDOSKI et al., 2012, p. 04).
\end{abstract}

Da mesma maneira que os autores anteriormente citados tem linhas de pensamento paralelos, é interessante acrescentar mais um conceito para formar uma miscelânea de autores e conceitos de diferentes nações. O termo kultur da língua alemã, segundo Elias (1994) pode ser traduzido para o termo cultura, mas de maneira bastante específica. $\mathrm{O}$ autor descreve que o termo kultur tem o significado de identidade e pertencimento de um grupo, reflete a consciência de um grupo que busca encontrar incessantemente suas fronteiras e identidade comum frente às diferenças de outros grupos. $\mathrm{O}$ autor faz a pergunta que fortalece a busca por essa representação “Qual é, realmente, nossa identidade?” Já o termo kultiviert, que seria uma derivação do termo kultur, refere-se à forma de conduta das pessoas, principalmente buscando encontrar unicidade na qualidade social das pessoas, suas habitações, suas maneiras e hábitos de fala e costumes.

Desta forma, fazendo uma relação entre Delgado, Barham, Tonietto e Elias, é possível inferir que as características de identificação dos vinhos de uma região é o seu terroir e, de forma análoga, o terroir de uma comunidade são suas características identitárias (kultur) (DAHER, 2013).

Valduga (2008) atenta ainda que devemos ter uma especial atenção ao usar o termo terroir e identidade, pois como cita o autor, existe uma banalização no uso desses termos com a intenção de inferir algum tipo diferenciado de agregação de valor ao produto, como uma forma 
mercadológica somente, desvinculando aspectos históricos que são inerentes dos termos. Podendo assim gerar um discurso vazio que foi apropriado pelos jargões do marketing.

Lembrando o que já foi conceituado por Tonietto, o terroir é basicamente o somatório de todas as características que podem diferenciar o produto (aspectos tangíveis e intangíveis, objetivos e subjetivos), no caso o vinho. No entanto, diferente das Indicações Geográficas (IGs), que são marcos com restrições geográficas com intuito de garantir a procedência de determinados produtos e não necessariamente a qualidade destes produtos, as indicações geográficas tem cunho de preservação mercadológica local. Não se trata necessariamente de uma forma de agregação de valor, mas sim de segregação de produtos e marcas. A prova disso pode ser evidenciada no caso do "Champagne" que nada mais é do que o vinho branco espumante produzido na região administrativa de Champagne-Ardenne na França. Uma bebida com as mesmas características que o champagne que foi produzido fora da região demarcada, não pode ser caracterizada como tal. Desta forma toda bebida com as mesmas características do champagne que for produzida fora desta indicação geográfica será denominada de espumante, somente, a não ser que esteja dentro de outra indicação geográfica. A própria região do Vale dos Vinhedos tem uma indicação geográfica, como mostra a figura 02.

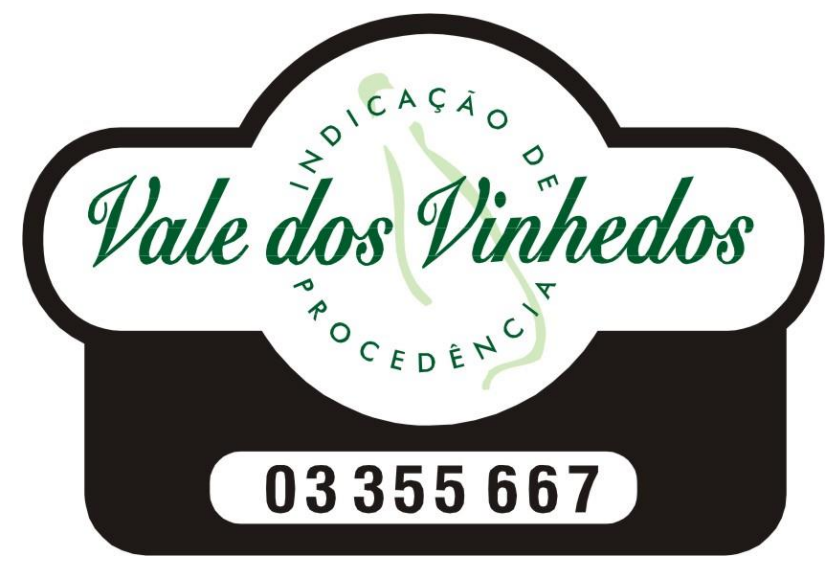

Figura 02: selo de indicação de procedência do Vale dos Vinhedos.

Fonte: Blogspot Vinho Fortaleza.

Cientes do papel da identidade como fator de identificação de um grupo, podemos imaginar que, assim como Stuart Hall prega que a relação de identidade na atualidade é cada vez mais provisória e essas mudanças são cada vez mais rápidas, o processo da globalização tem considerável importância nessa transitoriedade, advinda dos anos da informação e acessibilidade facilitada de todas as partes do mundo.

Alguns autores adeptos da linha de pensamento dos "hiperglobalizadores" acreditam que existe a tendência de a globalização gerar a homogeneização das culturas, das necessidades de consumo, dos hábitos sociais e da maioria dos aspectos sociais. No entanto, existe uma outra 
linha de pensamento, denominada de "céticos à globalização", que acreditam que a globalização não é esse fenômeno incontrolável que perpassa por fronteiras nacionais e modifica tudo, eles se apoiam na questão que muitos países fazem acordos de comércio entre um grupo fechado para se proteger do comércio global. Existe ainda uma terceira linha de pensamento que trabalha com a intermediação entre essas duas linhas, são os denominados "transformacionalistas", que pregam que a globalização é um processo dinâmico e aberto, sofre influência e é influenciado, não se trata de um fenômeno de sentido único (GIDDENS, 2008).

Da mesma forma que Giddens trata sobre as diferentes linhas de pensamento, mais especificamente sobre a linha de pensamento dos transformacionistas, Stuart Hall pondera que a globalização pode fortalecer as identidades locais ou a produção de novas identidades, pois como o próprio autor cita "as nações modernas são, todas, hibridas culturais" (HALL,2006, p. 14).

Cientes das ponderações dos autores, torna-se possível analisar a conversa que o enoturista-pesquisador e a pesquisadora Ornella Maiutto tiveram com o produtor Cesar Petrolli da vinícola Barcarola. O produtor Cesar Petrolli afirma que cultura do Vale dos Vinhedos não é a cultura italiana nem a brasileira, mas sim uma mistura de ambas as culturas. Ele cita alguns hábitos que os habitantes do Vale tem, que são notoriamente fruto desta mistura cultural. Segundo o produtor, o hábito de tomar chimarrão e comer churrasco é um hábito adquirido dos "gaúchos", a língua falada é o português do Brasil, mas com sotaque de italiano, o hábito de comer polenta, salame e copa e beber vinho vem da cultura italiana. Cesar havia dito que passou cinco anos morando na Itália fazendo cursos sobre vinhos e voltou para o Brasil. O produtor diz se identificar como "um brasileiro com raízes italianas".

Seria possível notar a questão do hibridismo cultural e as forças da globalização sobre as expressões culturais, assim como Hall e Giddens afirmam. No entanto, em outro momento da conversa com o produtor, ele relatou que durante sua experiência na Itália, as pessoas não o identificavam como brasileiro. Ele explica que em sua família e de muitos da região do Vale, são formadas por pessoas que só tem ligação sanguínea entre pessoas de famílias italianas. Diz que em sua família todos os antepassados são de origem italiana e que ainda não houve miscigenação com pessoas de famílias que não sejam italianas.

É interessante notar que da mesma forma que o produtor fala de seus antepassados todos oriundos de famílias italianas, ele diz que "ainda não houve miscigenação com pessoas" que não fossem de famílias italianas. No entanto, na própria fala do produtor, quando ele fala que "ainda não houve" seria possível inferir que o fato de usar a palavra "ainda" se refere a algo que não aconteceu no passado, mas ainda pode ocorrer. 
No entanto, Hall afirma que a questão de diferenciação cultural por meio de origens étnicas já está ultrapassada na atualidade. Nas palavras do autor:

A Europa ocidental não tem qualquer nação que seja composta de apenas um único povo, uma única cultura ou etnia. As nações modernas são, todas, híbridas culturais. A diferença genética - o último refúgio das ideologias racistas - não pode ser usada para distinguir um povo do outro. A raça é uma categoria discursiva e não uma categoria biológica. Isto é, ela é a categoria organizadora daquelas formas de falar, daqueles sistemas de representação e práticas sociais (HALL, 2006, p. 62).

Desta forma descrita por Hall, pouco importa se houve ou não relacionamentos entre pessoas de famílias que não fossem de origem italiana, pois mesmo que sua carga genética seja toda de origem italiana, certamente haverá mistura de diferentes povos na constituição de seus antepassados e quanto à questão cultural, como o mesmo produtor afirma, "a cultura do Vale é uma cultura de mistura".

Por meio da experiência vivida é possível inferir que a região do Vale dos Vinhedos é mais do que uma região produtora de vinhos, trata-se de uma região onde as tradições dos antepassados e as condições climáticas e geológicas favoreceram para a formação da impressão cultural dessa população. É interessante observar que a região é tão próxima das condições originais dos imigrantes italianos, que culmina no distanciamento das condições usuais das regiões brasileiras, tornado a região tão diferente e interessante para o enoturismo brasileiro.

\subsubsection{Festival Nacional do Vinho Colonial no Vale dos Vinhedos}

O Festival Nacional do Vinho Colonial (Figura 03) é uma iniciativa do Estado com o objetivo de preservar a identidade e a maneira tradicional da elaboração de vinhos, preservando a história, a cultura e o saber local. Trata-se de uma iniciativa de caráter multi-institucional onde a EMATER-RS juntamente com o apoio da Prefeitura Municipal de Bento Gonçalves, Secretaria de Desenvolvimento da Agricultura, Secretaria de Turismo, Instituto Federal do Rio Grande do Sul e Embrapa atuam de forma sinérgica para alcançar os objetivos do projeto (BENTO GONCALVES ${ }^{1}, 2013$ ). 


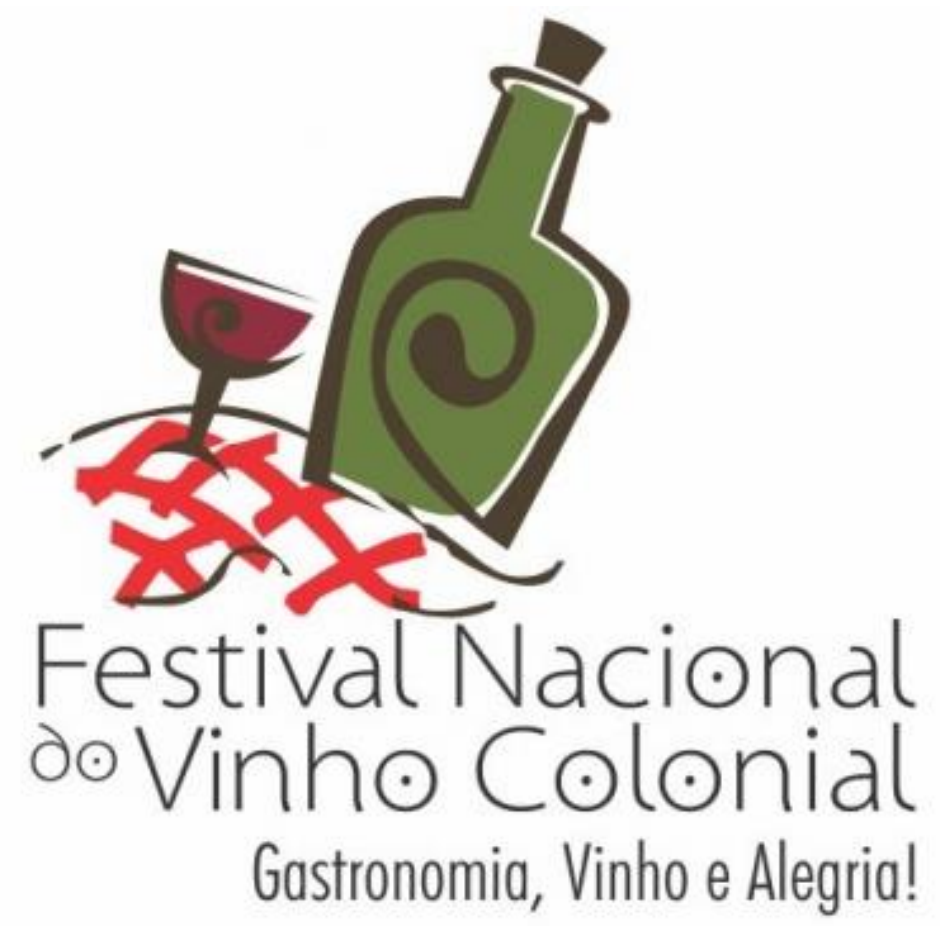

Figura 03: arte do Festival Nacional do Vinho Colonial.

Fonte: Município de Bento Gonçalves

A extensionista Maria de Lourdes Gasparin Pancotte, da EMATER-RS, afirma que "O principal objetivo do projeto é a valorização do vinho colonial que é produzido pelas pequenas famílias. Notamos que hoje, por exemplo, que o vinho colonial é muito prestigiado pelo turista, que procura experimentar produtos artesanais" (BENTO GONÇALVES², 2013). Em conversa ao telefone com a extensionista, no dia 18/07/2014, esta afirmou que além dos objetivos supracitados, são almejados com essas ações o resgate cultural e a geração de renda diversificada dos produtores. Segundo a extensionista, os vinhos coloniais estavam sendo desvalorizados frente aos vinhos finos da região.

O Segundo Festival Nacional do Vinho Colonial ocorreu na região do Vale dos Vinhedos no dia 05 de setembro de 2014, como mostra a foto 04 . O convite foi adquirido de um dos agricultores que expôs seus vinhos no festival. 


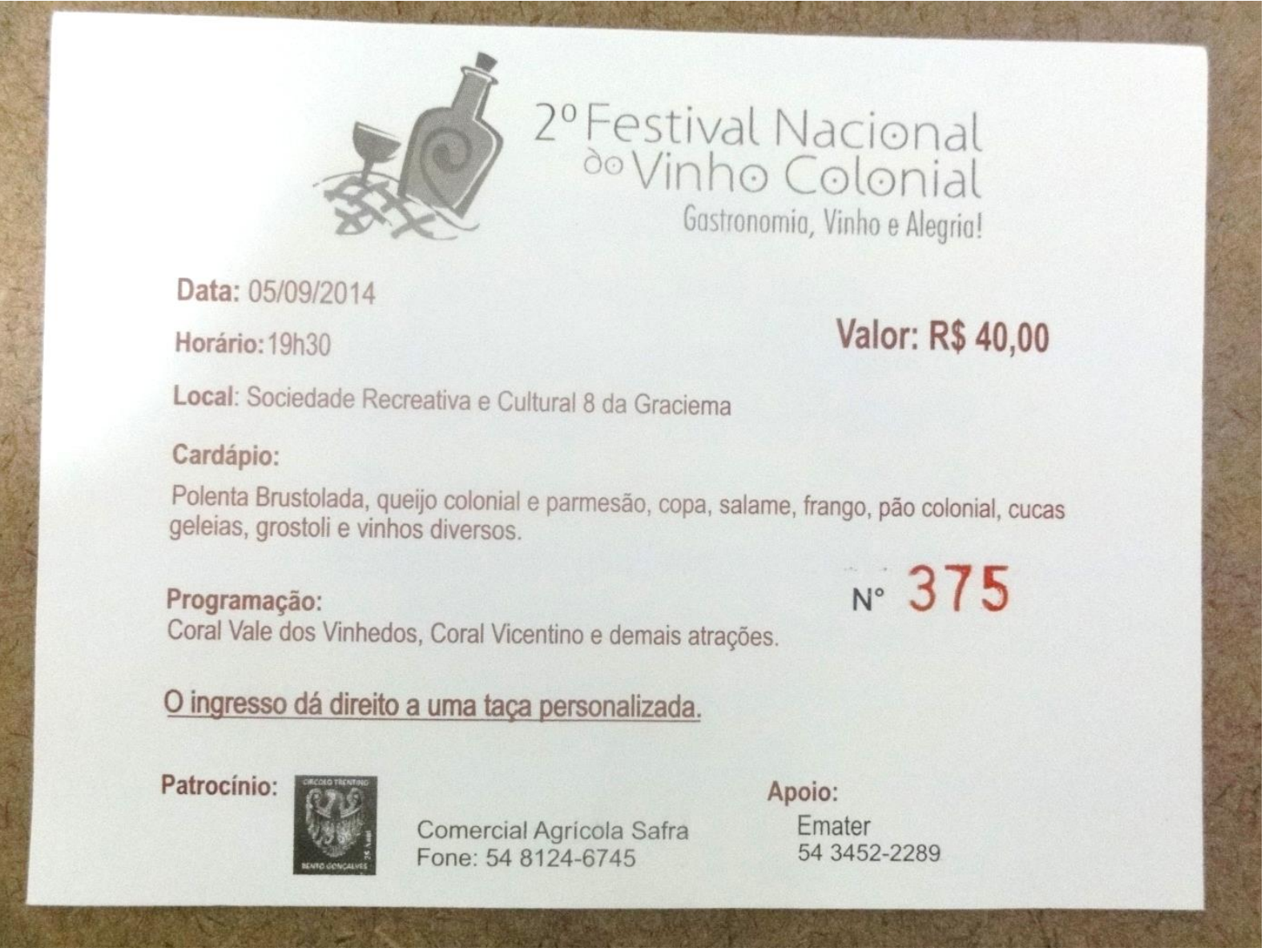

Foto 04: convite para o $2^{\circ}$ Festival Nacional do Vinho Colonial Fonte: acervo do autor (2014)

Posteriormente ao segundo festival nacional do vinho colonial, foi emitida uma nota pela Associação Comunitária do Vale dos Vinhedos que noticiava o sucesso dos objetivos alcançados no evento. Segundo a notícia, o evento conseguiu reunir aproximadamente 400 pessoas no salão 8 da Graciema.

\section{CAPÍTULO 2: METODOLOGIA}

Optou-se pela metodologia qualitativa pois demostrou-se ser a mais apropriada para esse tipo de pesquisa, por tratar-se de um assunto onde há vários fatores objetivos e subjetivos que se relacionam de maneira complexa.

Desta forma, Demo (2000) afirma que a pesquisa qualitativa deve fazer jus à complexidade da realidade, e para que isso ocorra é necessário que a pesquisa qualitativa se submeta à dinâmica complexa da realidade, e não o contrário. 
Foram realizadas visitas e entrevistas em todas as 14 propriedades dos vitivinicultores participantes do segundo Festival nacional de vinho colonial - Vale dos Vinhedos.

Inicialmente foi feito um primeiro contato com os 14 vitivinicultores que estavam expondo seus vinhos no festival. Nesse primeiro contato foi explicando sobre a pesquisa que estava sendo realizada e foi verificada a possibilidades de se fazer uma visita posteriormente para tratar melhor a pesquisa. Todos os agricultores foram solícitos e entregaram seus respectivos cartões com contatos.

Durante as visitas foram realizadas entrevistas abertas, onde haviam perguntas que eram feitas para todos os entrevistados e outras perguntas que eram feitas conforme o diálogo entre os envolvidos. As visitas eram feitas conforme o vitivinicultor tinha preferência, algumas foram feitas dentro de suas respectivas casas, outras dentro dos porões de produção vinícola e outras nos parreirais enquanto os agricultores faziam diversas atividades agrícolas. Em algumas visitas onde a entrevista era feita no campo, os vitivinicultores explicavam com muita propriedade sobre as fases e procedimentos necessários à condução da cultura da uva, método de vinificação, a dinâmica e relações no Vale dos Vinhedos.

Em estudo sobre metodologias científicas realizado por Creswell (2007), o autor aponta que a pesquisa qualitativa ocorre em um cenário natural à pesquisa, onde o pesquisador qualitativo deve ir ao local onde está o participante, pois essa ação permite que o pesquisador observe e que possa desenvolver um nível mais elevado das experiências reais e detalhes dos participantes.

Logo na primeira visita realizada, foi incluído um novo questionamento às perguntas que deveriam ser feitas a todos os produtores. O primeiro entrevistado afirmou que atualmente existe um grande êxodo por parte dos jovens da região e apontou essa ser uma preocupação corriqueira entre os agricultores mais velhos, principalmente pelo fato de não sentirem o envolvimento dos jovens e, consequentemente, desinteresse pela propriedade. A partir dessa afirmação do produtor, acrescentou-se o questionamento sobre quais seriam as possíveis ações que favoreceriam o envolvimento e interesse de permanência dos jovens na propriedade. $\mathrm{O}$ fato de acrescentar questionamentos durante a pesquisa, inicialmente pode ser visto com indiferenças e ressalvas, no entanto John Cresweel (2007) afirma que essas mudanças e acréscimos à pesquisa são desejáveis, uma vez que: 
A pesquisa qualitativa é emergente em vez de estritamente pré-configurada. Diversos aspectos surgem durante um estudo qualitativo. As questões de pesquisa podem mudar e ser refinadas à medida que o pesquisador descobre o que perguntar e para quem fazer as perguntas. (CRESWELL, 2007, p. 186).

Sendo assim, é notório que a cada visita realizada, uma nova visão e interpretação daquele cenário era acrescentada à visão do pesquisador, sendo bastante razoável que suas interpretações fossem acrescentadas de outros aspectos e logo modificadas.

Apoiando a ideia das mudanças ocorridas durante a pesquisa, Cresweel (2007) enfatiza que "as pesquisas qualitativas são fundamentalmente interpretativas" e diz que é impossível evitar as interpretações pessoais nas análises. Por esse motivo, esse tipo de pesquisa se apresentam de forma holística ao invés de microanálises, sendo assim o autor afirma que "quanto mais complexa, interativa e abrangente a narrativa, melhor o estudo qualitativo" (p. 187).

Inicialmente almejou-se identificar e qualificar o pesquisador nesse trabalho. O termo “enoturista-pesquisador" surgiu em um devaneio, de forma espontânea e sem grandes preocupações metodológicas. Durante alguns momentos iniciais da pesquisa cogitou-se não usar o termo, no entanto, o uso do termo "enoturista-pesquisador" se mostrou oportuno apoiado sobre a seguinte citação:

O pesquisador qualitativo reflete sistematicamente sobre quem é ele na investigação e é sensível à sua biografia pessoal e à maneira como ela molda o estudo. Essa introspecção e esse reconhecimento de vieses, valores e interesses tipifica a pesquisa qualitativa atualmente. $\mathrm{O}$ eu pessoal torna-se inseparável do eu pesquisador. Isso também representa honestidade e abertura para pesquisa, reconhecendo que toda a investigação é carregada de valores (MERTENS, 2003, apud CRESWELL, 2007, p. 187).

As visitas eram feitas de forma que o "entrevistado" se sentisse o mais confortável possível, sendo realizadas sem uma notória formalidade ou rigidez na sequência e frequência dos questionamentos. Objetivava-se que as entrevistas se tornassem mais próximas de conversas sobre assuntos que envolviam a produção do vinho colonial e o enoturismo que uma relação de perguntas e respostas pré-estabelecidas. As visitas tinham duração média de duas horas. As visitas feitas no campo normalmente eram as mais longas, pois era notório que o 
produtor não estava abdicando de suas atividades para conversar. Outro fator que tornava as visitas realizadas no campo mais duradouras e mais produtivas era a aparente simpatia conquistada pelo enoturista-pesquisador, uma vez que era possível conversar mais e com maior aprofundamento sobre os assuntos abordados. Sobre as intenções do enoturista-pesquisador e a metodologia aplicada, John Creswell (2007) tem um posicionamento que apoia a opção metodológica adotada, uma vez que "os pesquisadores qualitativos buscam o envolvimento dos participantes na sua coleta de dados e tentam estabelecer harmonia e credibilidade com as pessoas no estudo" (p. 186). O metodólogo aponta ainda que os pesquisadores qualitativos não devem perturbar o local e o participante mais do que o necessário.

Como objetivava tratar sobre vinho colonial, expectativas de melhorias e posicionamento do Estado, cada entrevista desencadeava numa conversa diferente das demais. Esse foi o motivo principal para que fosse feita visitas a todos os produtores. Foi notório que as respostas dadas às perguntas pré-estabelecidas se repetiam, mas o diálogo travado a partir dessas perguntas tornava cada visita única.

Optou-se por fazer um estudo de caso, pois existe literatura suficiente sobre a relação vinhos e colonização do Vale dos Vinhedos. Sobre o tema do enoturismo existem muitas publicações, principalmente no exterior, e algumas obras focadas sobre o enoturismo no Vale dos Vinhedos, mas até o momento (2015) nada foi publicado sobre o enoturismo de vinhos coloniais realizado no Vale dos Vinhedos sob a ótica dos produtores coloniais sobre a lei do vinho colonial.

A coleta dos dados deu-se na forma de entrevistas. Por meio de entrevistas é possível ter acesso às visões e opiniões dos participantes (CRESWEEL, 2007). Durante a pesquisa, optou-se por usar a expressão "visita" ao invés de entrevista. O primeiro motivo é que a ideia de ser entrevistado poderia gerar um certo desconforto aos produtores, ainda mais por estarem produzindo informalmente. Outro motivo é que o termo "visita" é usado corriqueiramente entre os extensionistas que tem contato frequente com os produtores. Em boa parte das visitas realizadas, o enoturista-pesquisador sentia que era tratado muito mais como um convidado do que como um entrevistador, pois em muitas das visitas eram feitos relatos que iam muito além das questões de pesquisa, obteve-se relatos em diversas formas, desde relatos confidenciais até críticas feitas abertamente aos donos de grandes "cantinas". É possível notar que, tais relatos só foram obtidos depois de um considerável tempo de conversa de forma que todos os envolvidos se sentissem livres e confortáveis para tratar dos assuntos com o mínimo de restrições e formalidade. 
Dias antes da viagem ao campo de pesquisa, foi ponderado sobre o uso de gravador de áudio nas visitas. Objetivando uma maior "entrega" e maior informalidade durante as visitas, optou-se por usar o gravador de áudio somente nas entrevistas mais formais como a entrevista realizada no gabinete do Deputado Pépe Vargas e com a socióloga e Extensionista Maria de Lourdes Gasparin Pancotte, com seus respectivos consentimentos.

Nas visitas feitas aos produtores foi usado o mínimo de material de pesquisa. Foi usado somente uma prancheta com papel e lápis para anotações e câmera fotográfica. Durante a visita eram feitas anotações pontuais, entre uma visita e outra era feita uma descrição mais apurada sobre a visita realizada e no final do dia eram passadas todas as informações, dados e observações feitas individualmente sobre cada visita. Foi feito um diário de pesquisa para que pudesse ser descrito o máximo possível de informações obtidas, mesmo que não necessariamente quando realizando as visitas.

\subsection{FOTOETNOGRAFIA}

Foi feito um ensaio etnográfico durante o festival nacional do vinho colonial. Por tratarse de um festival onde o vinho colonial é o principal atrativo, justifica-se a experiência da antropologia visual já que esse festival não se resume em apenas um objeto, o vinho colonial, mas todos os fatores que influenciam o fenômeno da produção do vinho aos modos coloniais.

Como a fotoetnografia é bastante usada em pesquisas de campo onde são estudados grupos da sociedade, suas características antropológicas, sociais e culturais (BONI e MORESCHI, 2007), desta forma, pode-se deduzir que o uso desta metodologia seria apropriada para o evento do Festival Nacional do Vinho Colonial, pois o festival como disse a socióloga e extensionista Maria de Lourdes Gasparin, é um evento onde almejasse resgatar a produção do vinho colonial como forma de produção cultural e afirmação das tradições locais.

A etnografia do festival foi feita por meio de duas óticas presentes, a primeira foi feita sob a perspectiva do enoturista-pesquisador e a segunda pela perspectiva de um dos filhos dos produtores de vinho colonial. O enoturista-pesquisador e o filho do produtor permaneceram durante todo o festival com uma câmera cada um para fotografar aquilo que consideravam mais importante.

No estudo etnográfico realizado por Luiz Eduardo Achutti (1997), este cita a passagem do pensador Bourdieu (1985), onde afirma que aquilo que cada grupo social elege para 
fotografar é o que considera digno de ser solenizado. O filho do produtor que se interessou em participar do estudo, senhor Tiago Crestani, foi informado que se tratava de uma pesquisa, e que a intenção seria que ele tirasse fotos daquilo que ele julgasse ser mais importante e memorável do festival. Corroborando com as exposições anteriores, Achutti (2004) ressalta a importância de deixar clara a finalidade do material fotoetnográfico para os envolvidos na pesquisa, e aponta que deve haver um planejamento de como executar tais fotografias.

A escolha do senhor Tiago Crestani para participar do ensaio fotoetnográfico deu-se por vários critérios: primeiramente por já conhecer o enoturista-pesquisador e se interessar pela pesquisa; ser filho do agricultor Jandir Crestani, que estava expondo no festival pelo segundo ano; ser conhecedor da cultura local e da importância do festival do vinho colonial para aquela comunidade e ter facilidade para manusear a câmera fotográfica. Boni e Moreschi (2007) apontam que a adoção de determinados critérios corresponde à credibilidade científica e seriedade no resultado final. Os autores afirmam que:

Deve-se levar em conta a importância do conhecimento pessoal do fotógrafo a respeito de antropologia ou, no sentido inverso, do pesquisador sobre as técnicas fotográficas. Do contrário, em ambos os casos podem haver distorções no objetivo da pesquisa e coleta de materiais (BONI E MORESCHI, 2007, p. 139).

No dia posterior ao festival as fotos de cada câmera foram identificadas para posterior análise do material. 


\section{CAPÍTULO 3: ANÁLISE DO ESTUDO DE CASO OBSERVADO}

\subsection{FOTOETNOGRAFIA NO FESTIVAL NACIONAL DO VINHO COLONIAL}

Durante o festival foi feita uma coleta de campo usando o método da fotoetnografia, onde tanto o enoturista-pesquisador como um produtor captaram as imagens que consideraram mais importantes. Será iniciada a exposição fotoetnográfica com as dez fotografias feitas sob a ótica do enoturista-pesquisador.

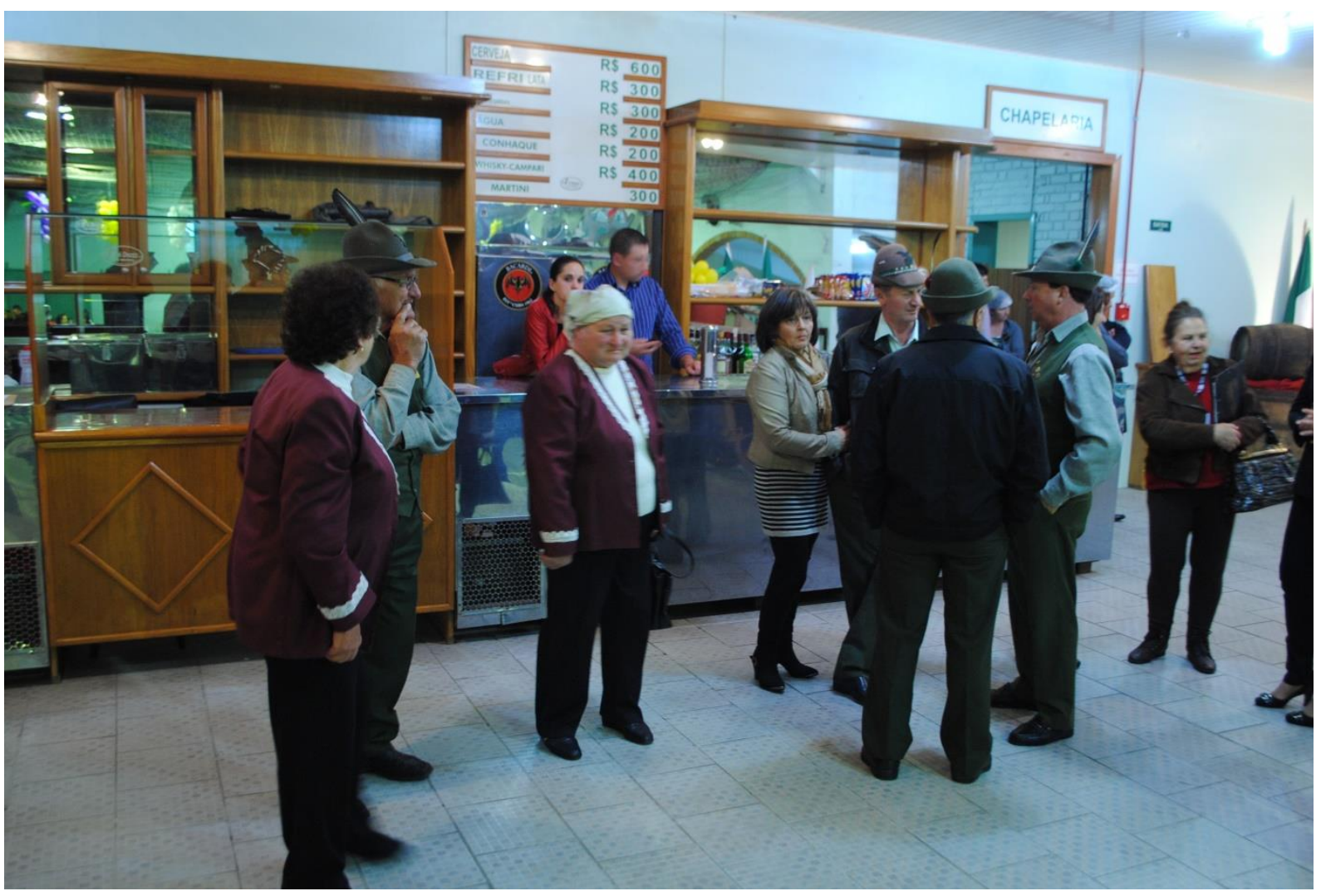

Foto 05: chapelaria

Fonte: acervo do autor (2014)

$\mathrm{Na}$ chapelaria, logo na entrada do salão, é possível observar várias pessoas com trajes típicos tiroleses, foi possível notar que somente os senhores e senhoras de idade mais avançada estavam trajados à tirolesa. Esta foto foi tirada logo nos primeiros minutos da festa, onde a maioria dos presentes eram de pessoas de idade mais avançada, ao passo que com o passar do tempo pessoas de outras idades foram chegando. Ao final da festa a maioria das pessoas de mais idade já haviam indo embora.

Quanto ao fato da pontualidade dos mais experientes, seria possível inferir que pelo fato de a festa movimentar toda a comunidade, os mais idosos trataram do festival do vinho colonial 
como o evento do dia, vestindo suas roupas mais tradicionais e possivelmente aguardando atentamente ao horário para ir para a confraternização.

Os filhos e netos desses senhores não trajavam roupas típicas tirolesas. A primeira e segunda geração depois desses senhores tipicamente trajados usavam roupas usuais de suas respectivas idades.

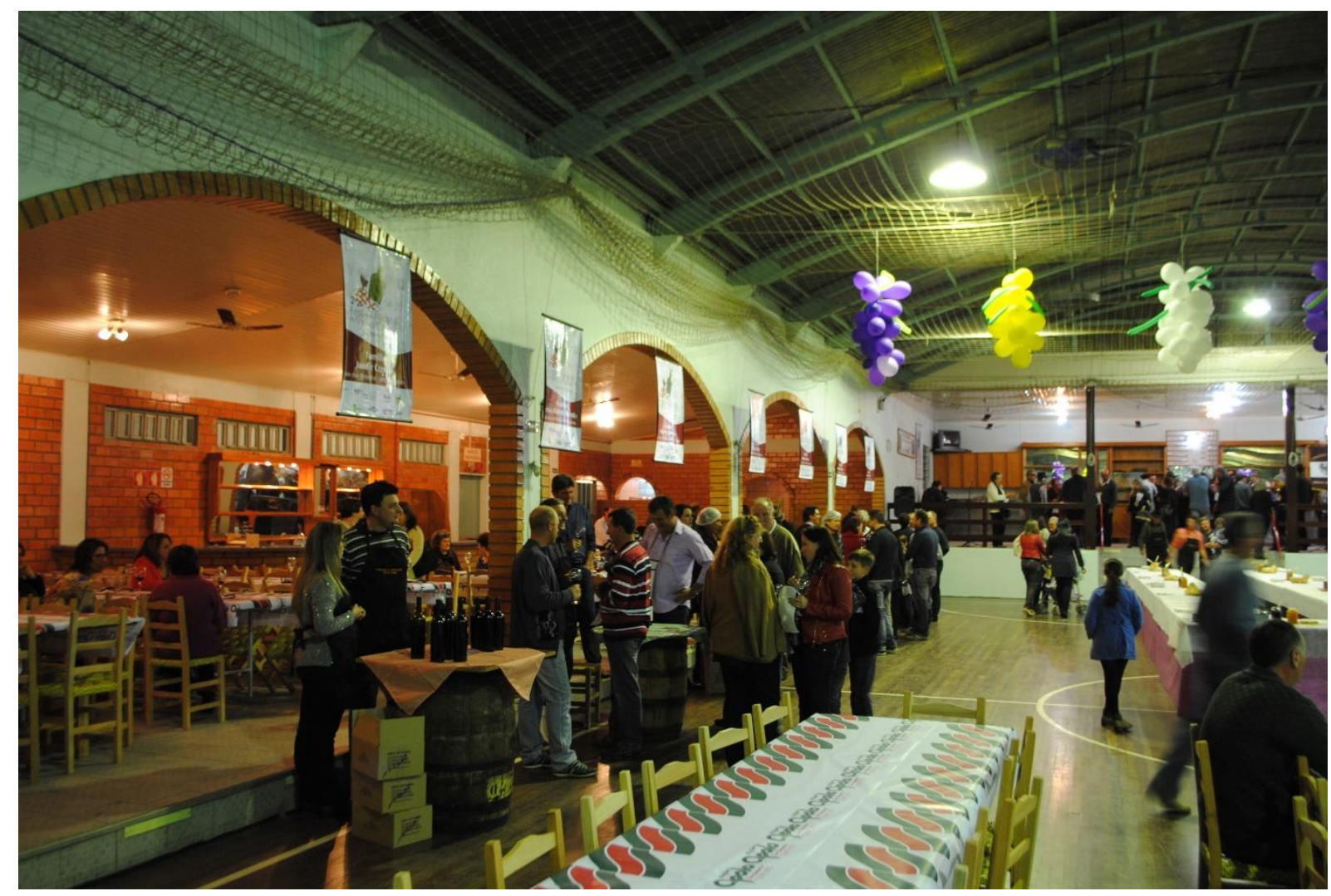

Foto 06: lateral do salão

Fonte: acervo do autor (2014)

Esta foto foi tirada passados alguns minutos do início da festa. É possível observar que o salão ainda estava vazio se comparado com o transcorrer da festa. Cada um dos produtores de vinho colonial que tiveram seus vinhos classificados pelos técnicos da Emater tinham uma mesa de barril antigo e um banner para expor seus vinhos e sucos coloniais.

Neste ângulo é possível ver o produtor Tiago Crestani junto com sua namorada, logo no primeiro barril. As mesas foram acomodadas de maneira a formar longas mesas e foram forradas com papel do mercado local. Foram feitos arranjos de balão que simulavam diferentes colorações de uvas. Neste ângulo é possível observar que o salão do festival é também usado como ambiente para jogar futebol de salão, como pode ser visto nas marcas do chão. 


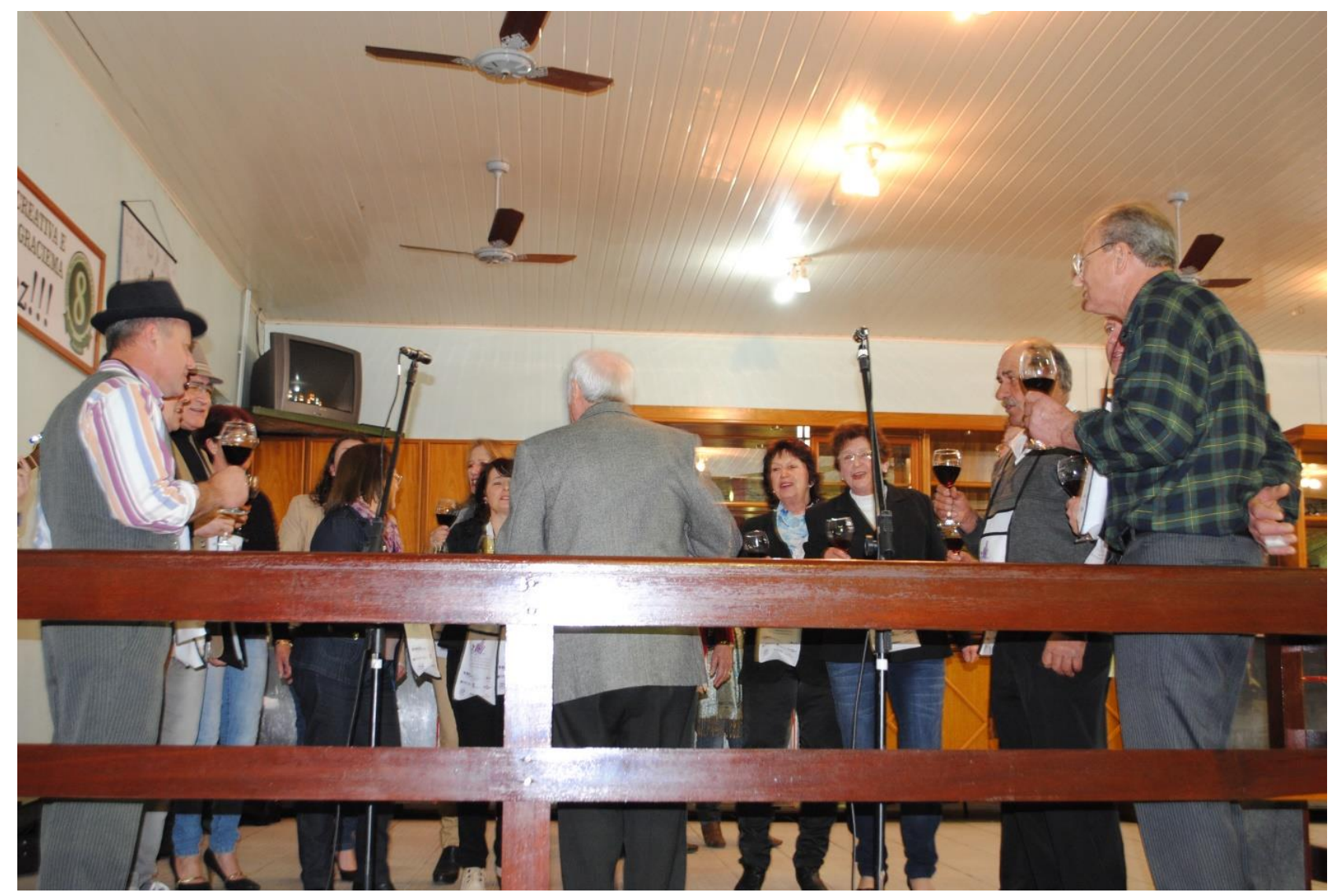

Foto 07: coral do vinho

Fonte: acervo do autor (2014)

A foto do coral do vinho foi feita com o intuito de mostrar como os produtores e frequentadores da festa mantém viva a tradição e a cultura do vinho. Podemos ver que a maioria dos coristas aparentemente já passaram dos 50 anos de idade, todos com suas taças de vinho a mão estavam cantando músicas italianas.

Vale a pena atentar para o detalhe da mão do produtor Jandir Crestani, com camisa quadriculada, que estava com algum ferimento no dedo, que possivelmente o adquiriu em seu trabalho no campo. É interessante notar a postura do produtor ao posicionar a mão ferida para trás como uma possível forma de expressar que seu ferimento não é um fator limitante naquele momento, e que a circunstância presente o faz literalmente dar as costas às dores do trabalho e aproveitar os frutos dele. 


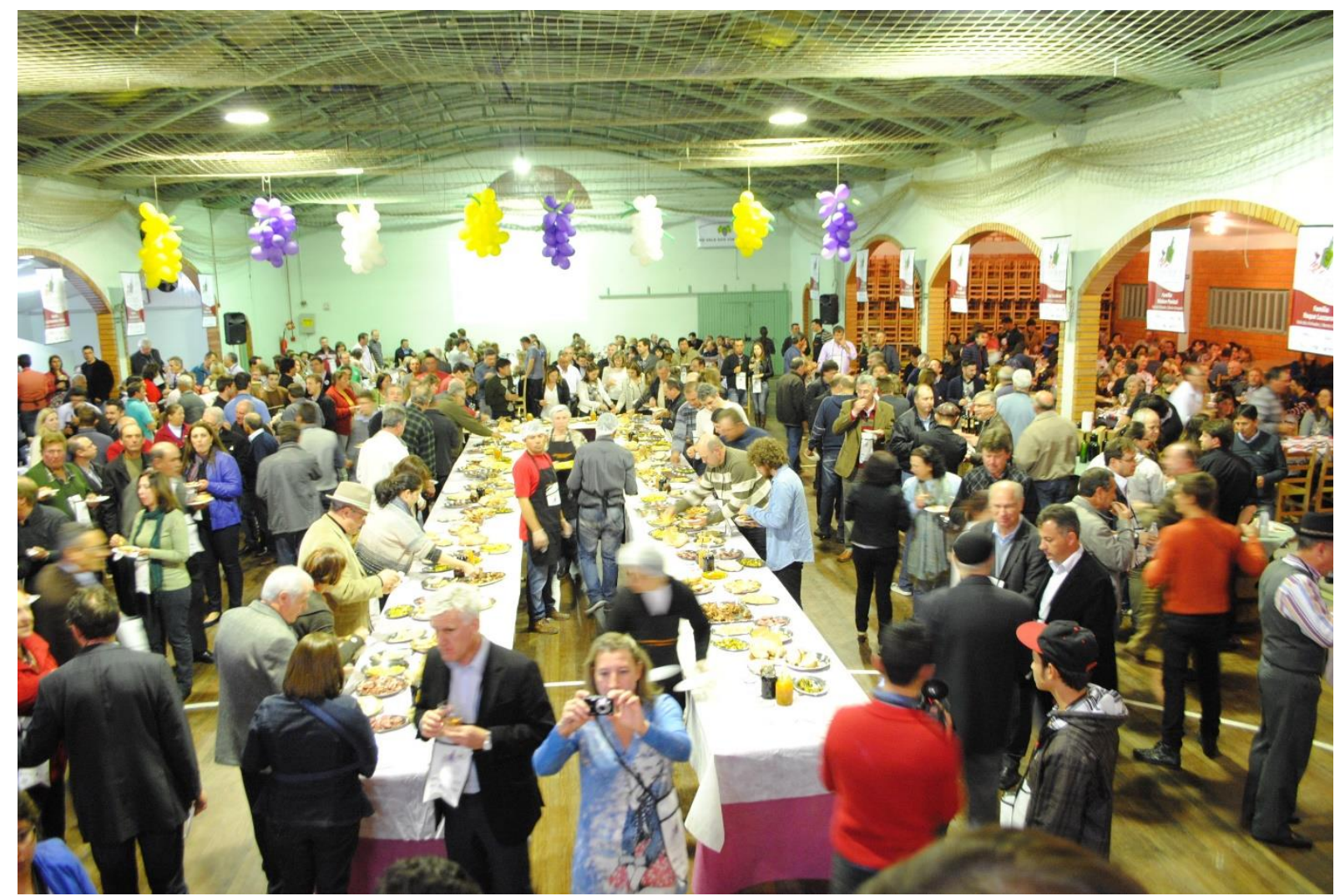

Foto 08: Segundo Festival Nacional do Vinho Colonial

Fonte: acervo do autor (2014)

A foto 08 foi tirada para evidenciar a quantidade de pessoas presentes no festival. Possivelmente este foi o momento de lotação máxima do evento. É possível notar nessa foto que, mesmo com a grande mesa fartamente posta, a atenção da maioria dos presentes ainda são os vinhos e sucos coloniais. É notório que a maioria dos presentes estão envolta ou perto dos locais onde estão sendo servidos os vinhos coloniais pelos produtores. 


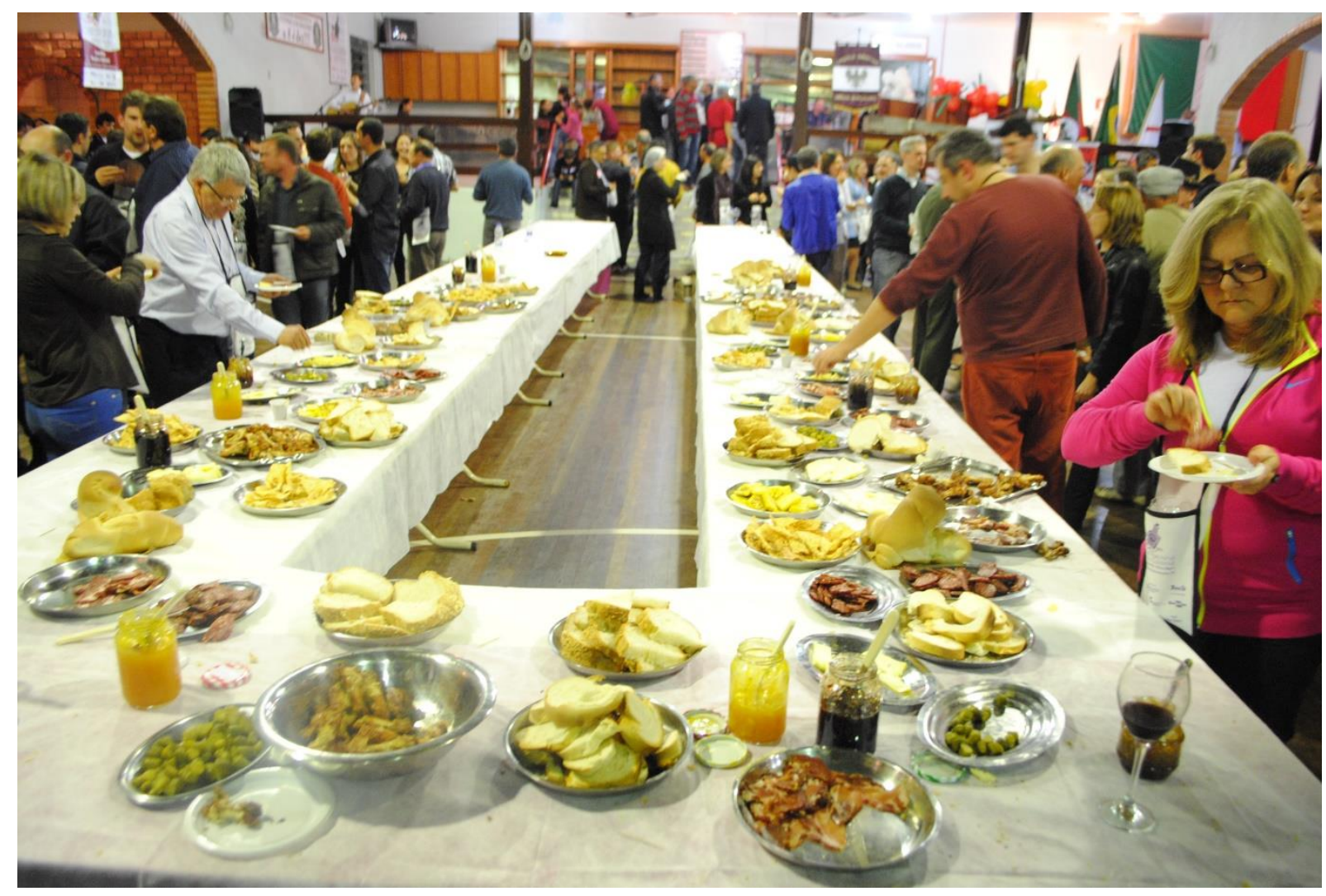

Foto 09: mesa farta

Fonte: acervo do autor (2014)

Já na foto 09 é possível ver a fartura da mesa com comidas típicas daquela comunidade. Pela foto é possível notar que foi servido pão caseiro, copa e salame, geleia de uva e physalis, galeto, polenta frita e assada, queijos, picles e batata frita. Nesta imagem é possível visualizar que o "porta-taça" dado aos convidados foi bastante útil, pois como pode ser visto tanto a senhora à direita como o senhor à esquerda estão usando seus "portas-taça", de modo que podem ficar com as duas mãos livres para comer e se servir. Em conversa com o produtor José Milani, este disse que o "guarda taça" foi uma alternativa pensada pelos organizadores depois da primeira edição do festival, pois notaram a dificuldade dos presentes ao manusear a taça e se alimentar. 


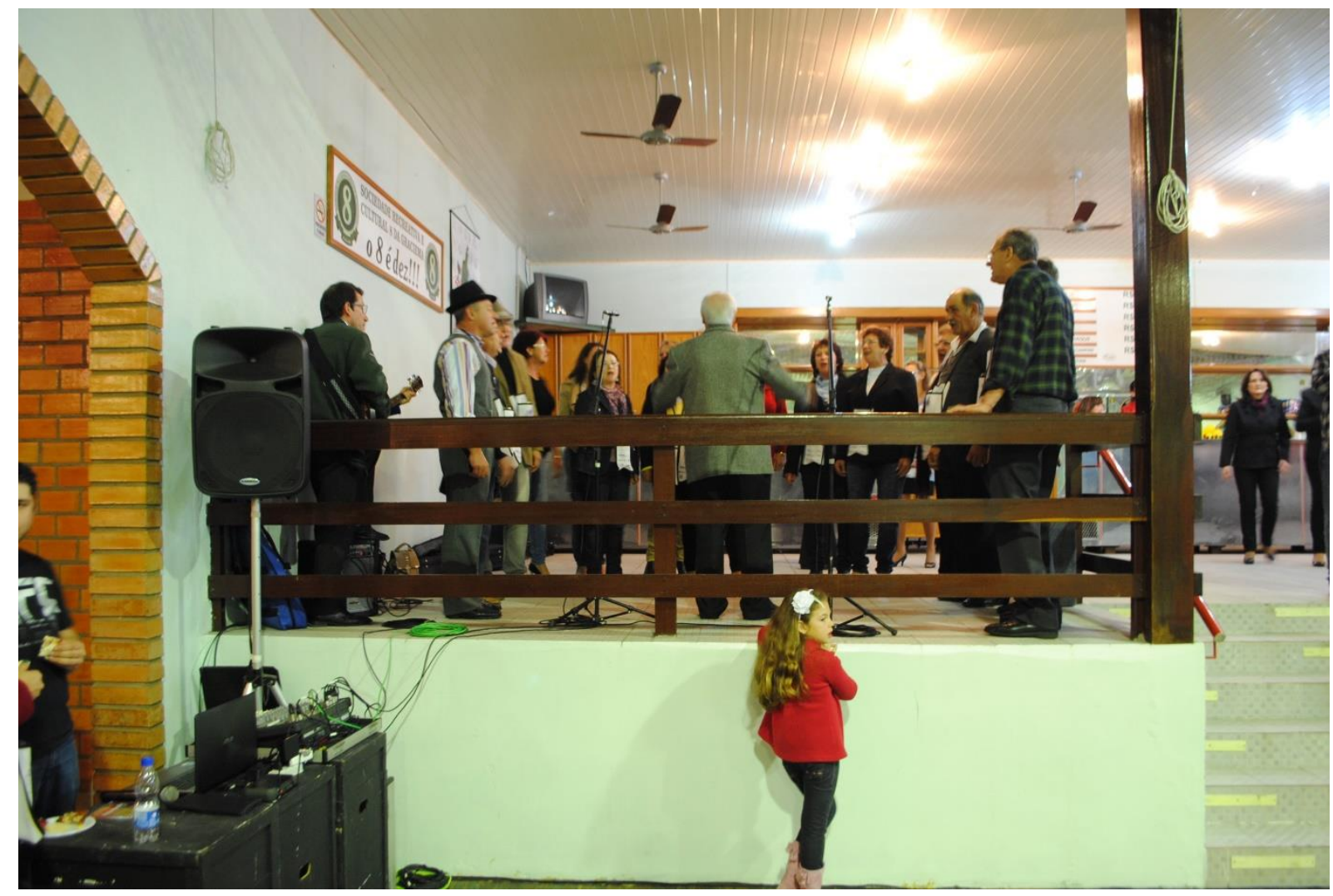

Foto 10: menina sentindo a música

Fonte: acervo do autor (2014)

Tanto a foto 10 como a foto 11 foram tiradas para demostrar algumas das formas que as crianças tem acesso e são influenciadas pela cultura local e tradições daquela comunidade. $\mathrm{Na}$ fotografia acima, é possível perceber a menina que, entre uma brincadeira e outra, sempre ao som de música italiana, parou por algum tempo para observar e ouvir o coral de músicas tradicionais. Em umas das músicas cantadas pelos coristas chamou a atenção do enoturistapesquisador a letra da música "La bella polenta” que ensina como deve ser feita a polenta desde a semeadura até o modo de comer. Segundo a música: "Quando si mangia la bella polenta, La bella polenta si mangia così, Si pianta così, la cresce così, Fiorisce così, si smissia così, si taia così, si gusta così, si mangia così...”. 


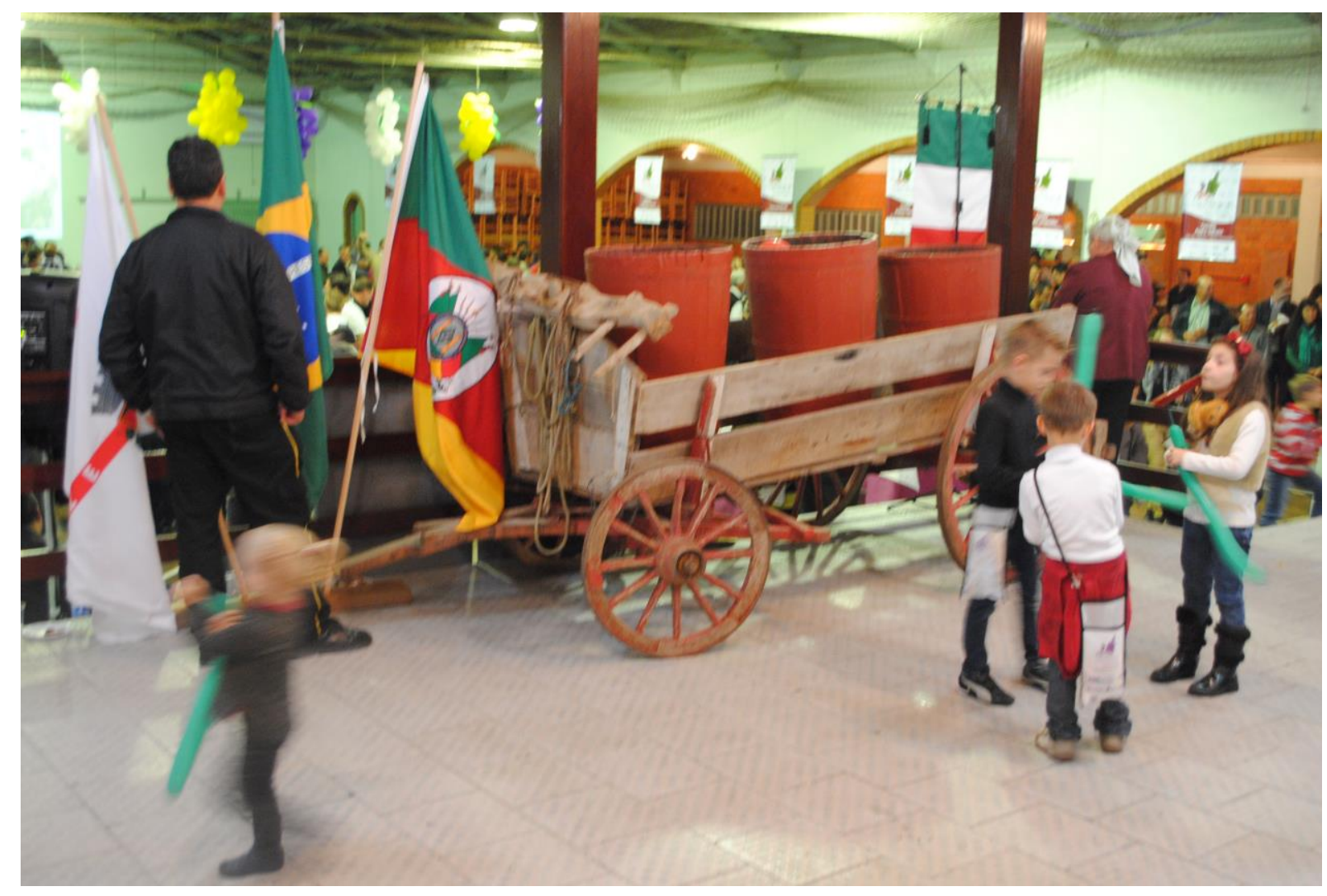

Foto 11: crianças brincando em meio aos símbolos e signos da tradição

Fonte: acervo do autor (2014)

O escritor Goethe afirma que a juventude é a embriaguez sem vinho. Esse fato foi notado durante o festival. Se por um lado os adultos bebiam vinho e tornavam-se mais alegres, as crianças são alegres pela idade e alegravam o ambiente. Chamou a atenção do enoturistapesquisador a quantidade de crianças presentes no festival do vinho colonial, fato este que não é concebido em festivais de outras bebidas. É interessante analisar a presença das crianças no festival de vinho colonial por vários aspectos, se por um lado os pais acreditam que o festival do vinho colonial não é caracterizado como um ambiente impróprio para as crianças possivelmente pelo fato do vinho fazer parte da vida daquela comunidade, e existem ainda aqueles que consideram que o vinho, principalmente o vinho colonial, deve ser tratado como alimento, por outro sabe-se que as crianças tendem a imitar os adultos. Na foto 11 podemos ver o garoto de camisa branca imitando os adultos com o "porta-taça" vazio sobre os ombros.

É interessante notar que desde a infância as crianças daquela comunidade já são influenciadas e introduzidas aos signos da cultura local. Se analisarmos superficialmente a cena, podemos rapidamente notar arranjos de balões no formato de cachos de uvas, o que possivelmente irá resultar que essas crianças sintam mais familiaridade com as uvas que outras 
frutas. No entanto, se observarmos de maneira mais atenciosa, podemos notar que essas crianças estão envoltas de vários signos: haviam balões da cor e formato de cachos de uvas, balões com as cores da bandeira do estado do Rio Grande do Sul e da bandeira italiana. É possível observar as bandeiras do município de Bento Gonçalves, do Brasil e do Rio Grande do Sul. Mais à direita da foto é possível ver uma bandeira da Itália ao lado de uma senhora vestida com as roupas tradicionais de tirolesa. Podemos observar também um carro de boi e as cordas, ambos instrumentos frequentemente usados pelos colonos no passado, o carro de boi tem uma longa história do Rio Grande do Sul, desde a utilização do carro de boi na guerra dos farrapos por Giuseppe Garibaldi e como o meio de transporte usado na chegada e trabalho dos colonos italianos; já as cordas são signos do trabalho no campo, ainda muito usado nas regiões ganadeiras do sul. Sobre o carro de boi, havia três jarros remetendo ao período da colheita das uvas ou Vindima. Como se já não fosse uma alta carga de signos da cultura local, as crianças brincavam o tempo todo ao som de músicas tradicionais cantadas em italiano.

Desta forma exposta,é possível dizer que a presença das crianças no festival do vinho colonial é algo bastante positivo para a perpetuação da cultura local e formação da identidade daquela comunidade.

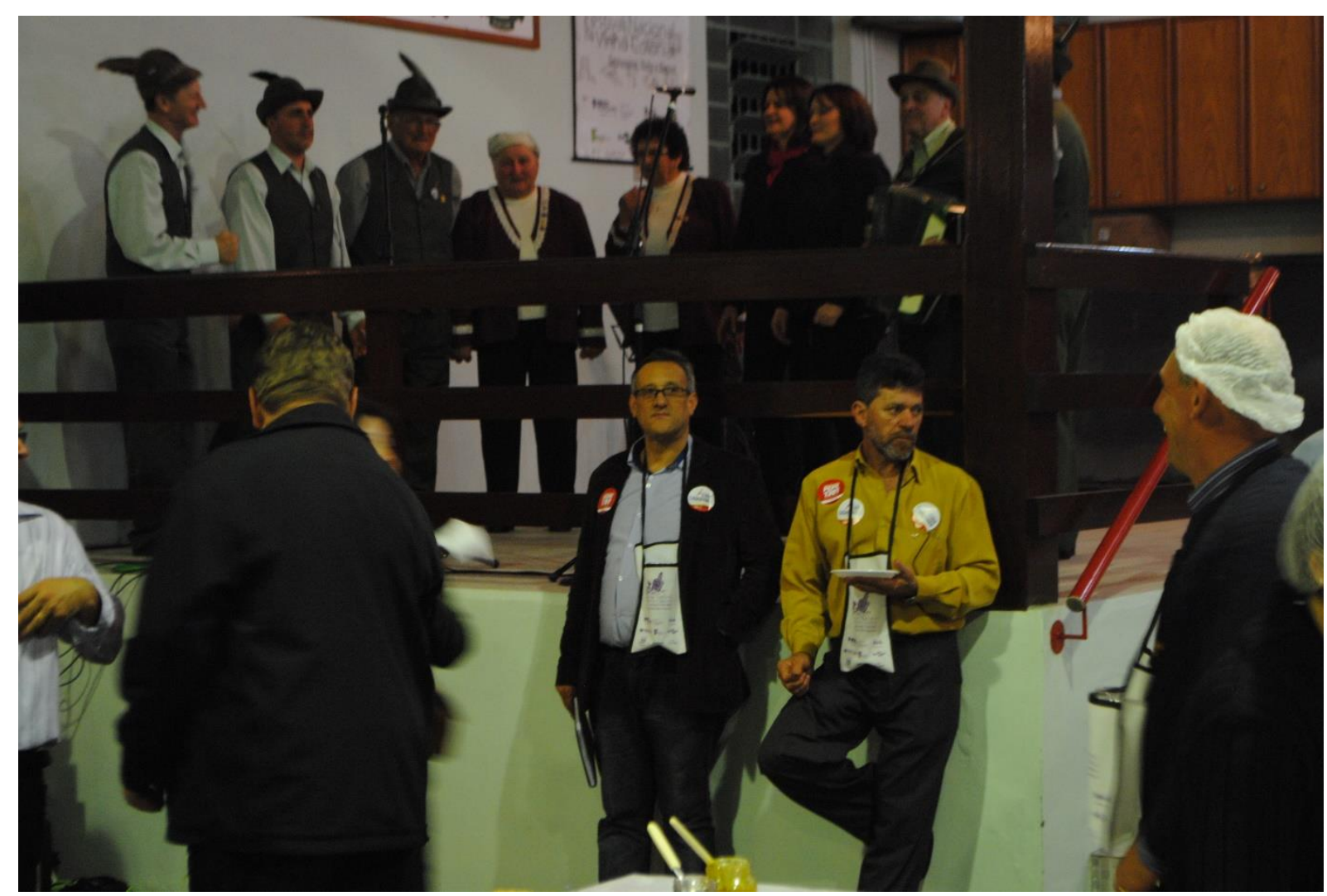

Foto 12: interesses político partidário

Fonte: acervo do autor (2014) 
Houve um rápido discurso de um deputado do estado que entrou com seus apoiadores no festival. Segundo o produtor Mateus Dalla Corte, esses apoiadores políticos da foto não são da região do Vale. Segundo a afirmação do produtor e ao analisar a fotografia é possível inferir que os apoiadores políticos em foco não são integrantes daquela comunidade, pois não estão interagindo com os presentes e aparentemente não estão se sentindo integrantes ou pertencentes daquele local. Outro detalhe que poderia indicar a sensação do não pertencimento ao ambiente seria o descaso de um deles ao colocar o pé na parede do salão.

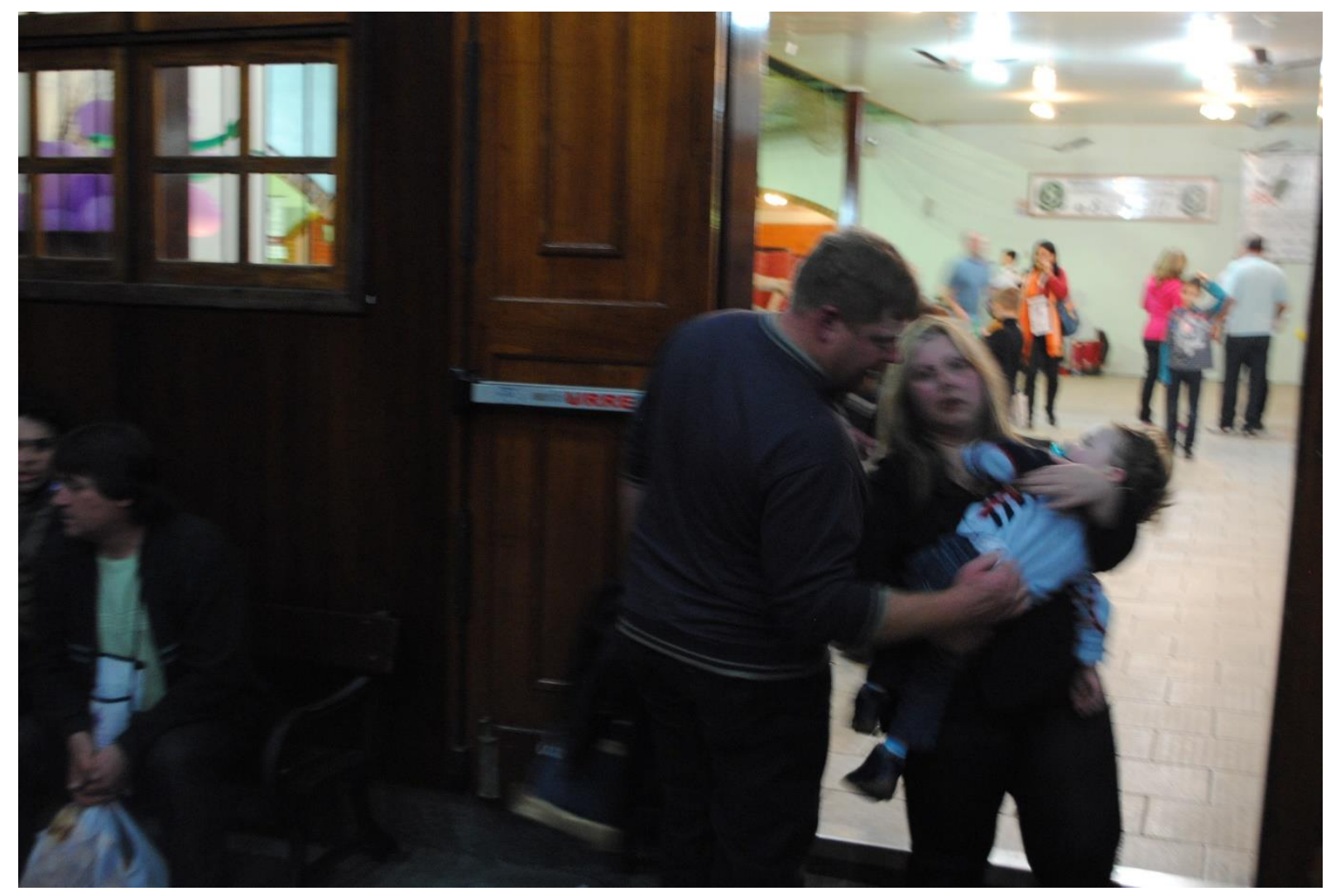

Foto 13: ao cair da noite

Fonte: acervo do autor (2014)

No decorrer da festa é possível observar a presença de alguns papeis que numa visão rápida pode passar desapercebida. As mulheres no Vale dos Vinhedos, assim como na maioria dos ambientes rurais, tem seus papeis subjugados em relação às funções dos homens em nossa sociedade. No entanto, nessa foto pode-se observar a função fulcral da mulher em literalmente dar o apoio necessário e oportuno à família na escolha da hora de ir para casa. Se por um lado a criança teve suas energias consumidas pela "embriaguez sem vinho" da juventude, seu marido apresenta-se com o rosto corado não pelo mesmo motivo do filho. 


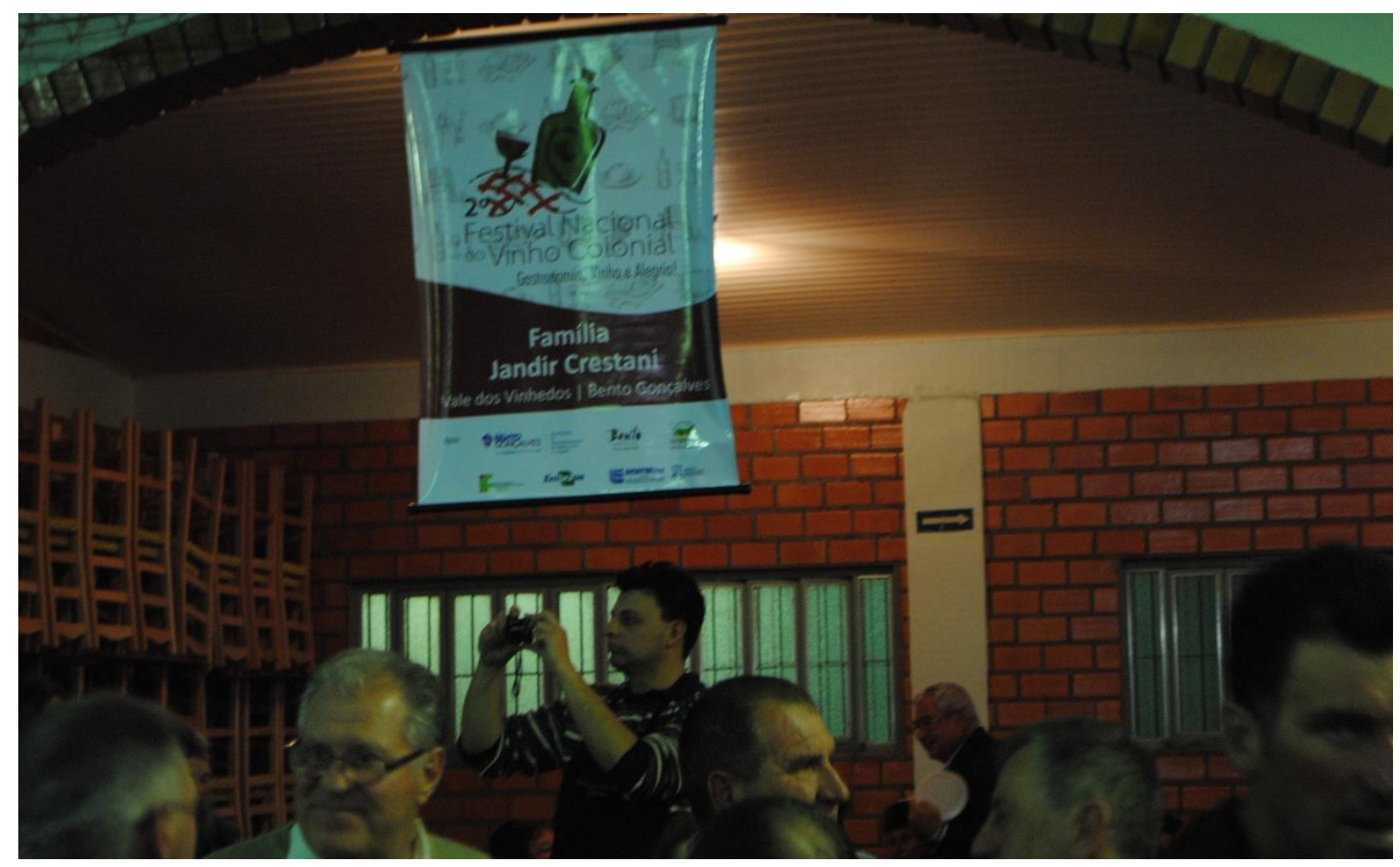

Foto 14: Tiago Crestani

Fonte: acervo do autor (2014)

Tiago Crestani é o filho do produtor Jandir Crestani que fez as fotos sob seu olhar do festival. As próximas dez fotografias foram feitas sob a ótica de Tiago Crestani.

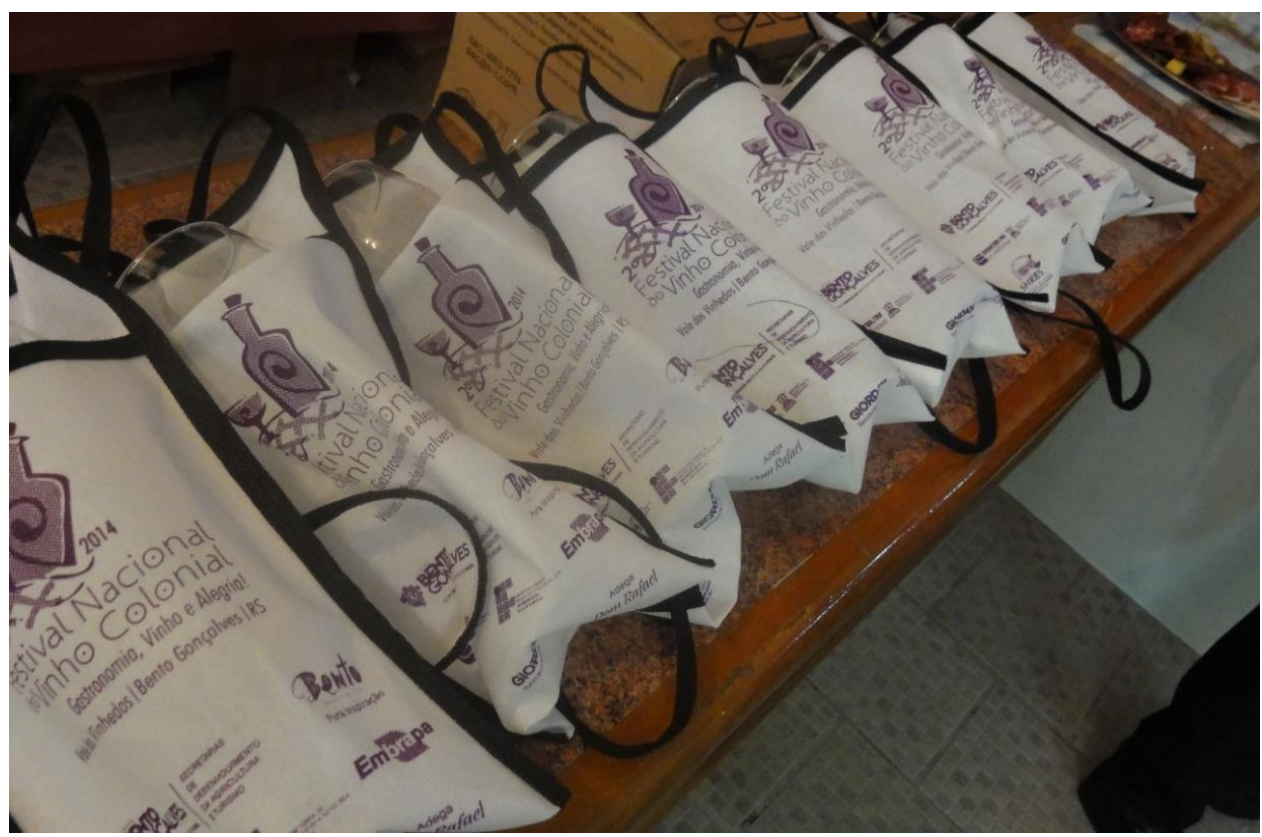

Foto 15: taças e "porta-taças"

Fonte: acervo do autor (2014) 
Logo na entrada do galpão os convidados retiravam seus kits com porta taças e taças. Quando o enoturista-pesquisador chegou ao festival se deparou com a mesa repleta de brindes, mas não havia dado a atenção necessária. Posteriormente ao festival em conversa com os produtores, foi explicado por alguns produtores da inovação, como eles mesmos tratam, o fato de o evento deste ano ter o porta-taça. Como já foi dito anteriormente, o porta-taça foi uma necessidade sentida pelos produtores e frequentadores na primeira edição do festival e foi implementada na sua segunda edição. Como Tiago Crestani sabia desta demanda, fotografou a inovação deste festival.

É interessante notar que da mesma forma que alguns produtores buscam por inovações no fabrico de vinho, os produtores que organizaram o festival buscaram fazer algumas inovações na forma de melhor atender às demandas de seus convidados no festival de vinho colonial.

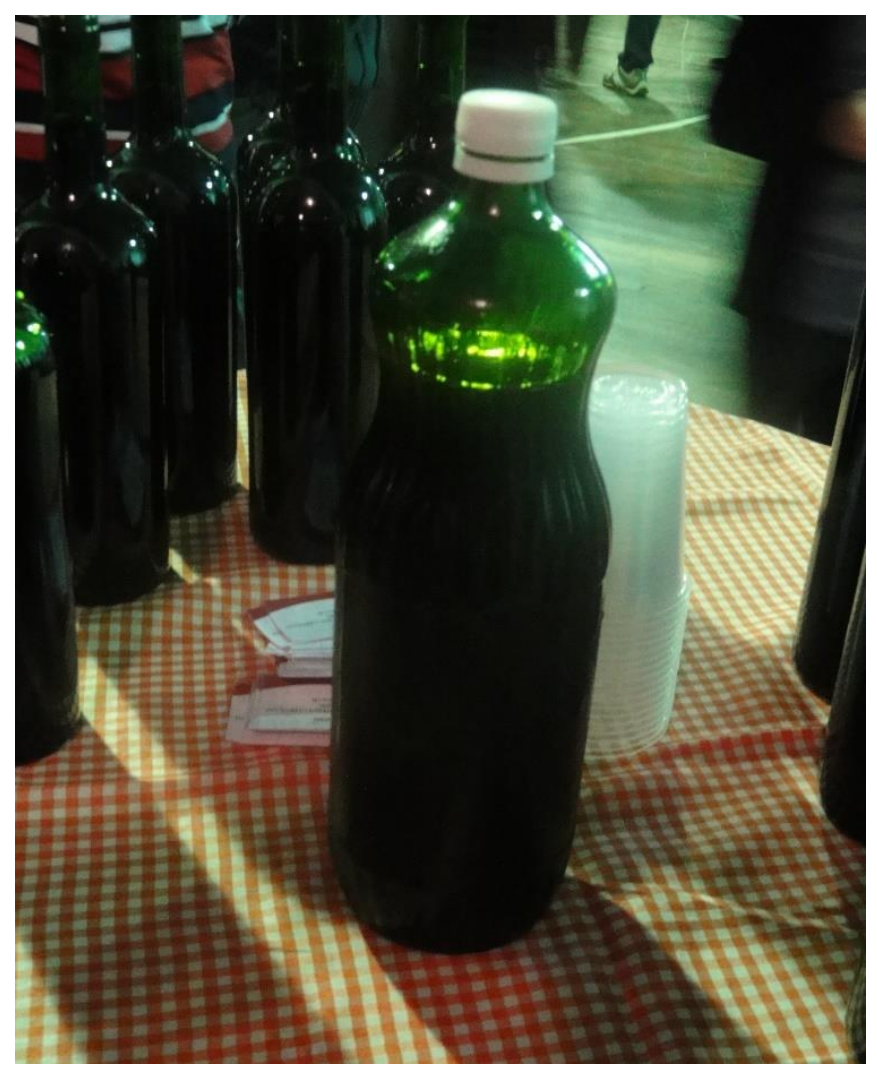

Foto 16: suco colonial

Fonte: acervo do autor (2014)

O festival retratado é do vinho colonial, mas os sucos coloniais também são peças igualmente fundamentais no festival. O suco de uva colonial é consumido em quantidades parecidas com a dos vinhos no festival. Ao observar essa fotografia feita pelo produtor Tiago Crestani pode parecer uma simples garrafa de suco colonial sob um olhar de alguém que não conhece a produção da família Crestani, no entanto com a experiência vivida ao fazer o estudo 
de campo, o enoturista-pesquisador pode notar que os sucos coloniais produzidos pela família Crestani são mais saborosos que os demais sucos produzidos na região, lembrando que as preferências gustativas são bastante individuais. Em conversa com a senhora Vilma Crestani, que cuida da pousada que o enoturista-pesquisador esteve durante a pesquisa de campo, ela disse que muitos turistas que se hospedam no local querem levar algumas garrafas do suco colonial. Ela afirma que vende algumas garrafas para os turistas consumirem em casa, mas diz que o principal intuito da produção de sucos coloniais é servi-los para os turistas durante sua estada.

Diante dessas informações seria possível inferir que naquela garrafa de suco colonial existe um discurso de tradição da produção, atenção ao turista e inovação nos meios de obtenção de receitas alternativas, que no caso da família Crestani é a pousada, que era considerada a atividade alternativa e hoje é a principal fonte de renda da propriedade. Pode-se dizer que pelo fato do suco colonial servido ser reconhecido pelos turistas como um produto de alta qualidade, e parte dessa mudança de atividade alternativa se tornar atividade principal, é mérito do trabalho de elaboração do suco colonial produzido pela família Crestani.

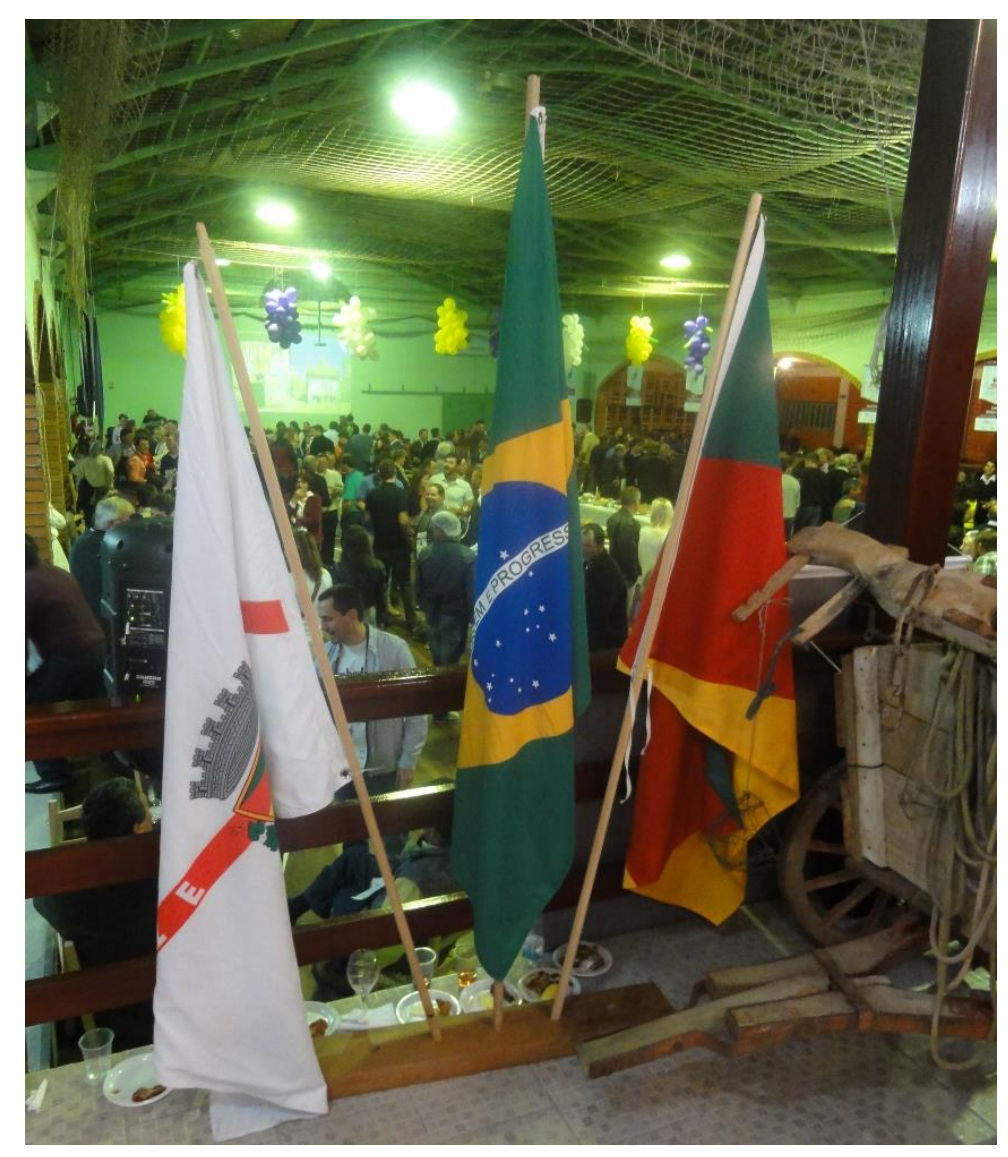

Foto 17: bandeiras

Fonte: acervo do autor (2014) 
As bandeiras são signos reconhecidos como formas de expressar a identidade de um povo, no caso da foto acima podemos ver que Tiago Crestani colocou vários símbolos de identidade no primeiro plano e a população como plano de funda da fotografia.

Em conversa com alguns dos organizadores do festival foi dito que a maioria dos frequentadores do primeiro festival do vinho colonial eram de pessoas da própria comunidade. Os convites são vendidos pelas mãos dos próprios produtores participantes do festival, apesar de ser possível comprar os convites na hora do festival na entrada, mas o fato da maior parte da venda dos convites estarem atreladas aos produtores é um argumento válido para provar que a maioria dos presentes são daquela comunidade, ao passo que seria possível inferir que aqueles símbolos identitários em primeiro plano da foto representam, pelo menos a maior parte daquela comunidade no plano de fundo da foto.

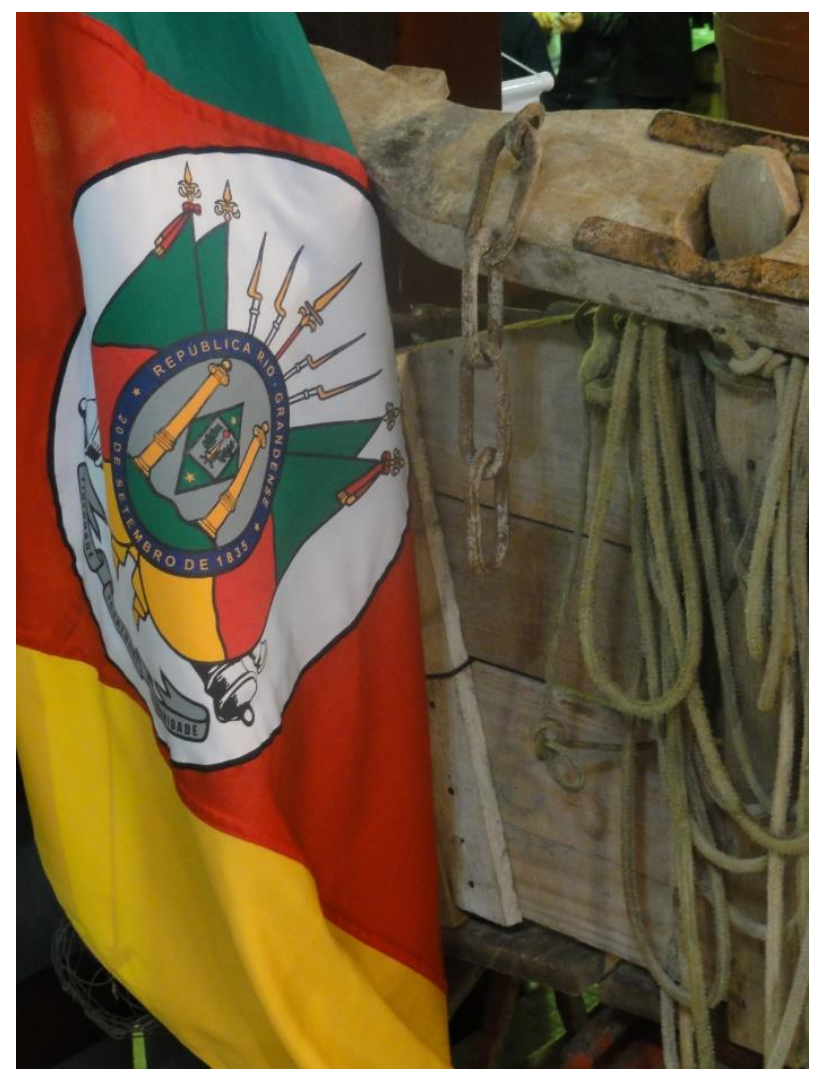

Foto 18: marcas do Rio Grande do Sul

Fonte: acervo do autor (2014)

Nesta fotografia é possível ver que o produtor teve a atenção para colocar alguns símbolos que representam não só aquela localidade, mas boa parte do estado do Rio Grande do Sul. Nesta foto é possível ver a bandeira do estado gaúcho com suas cores e armas características ao lado do carro de boi com suas cordas e correntes que são característicos de 
regiões agrárias demostrando a forte relação que o Rio Grande do Sul tem com as atividades agrárias.

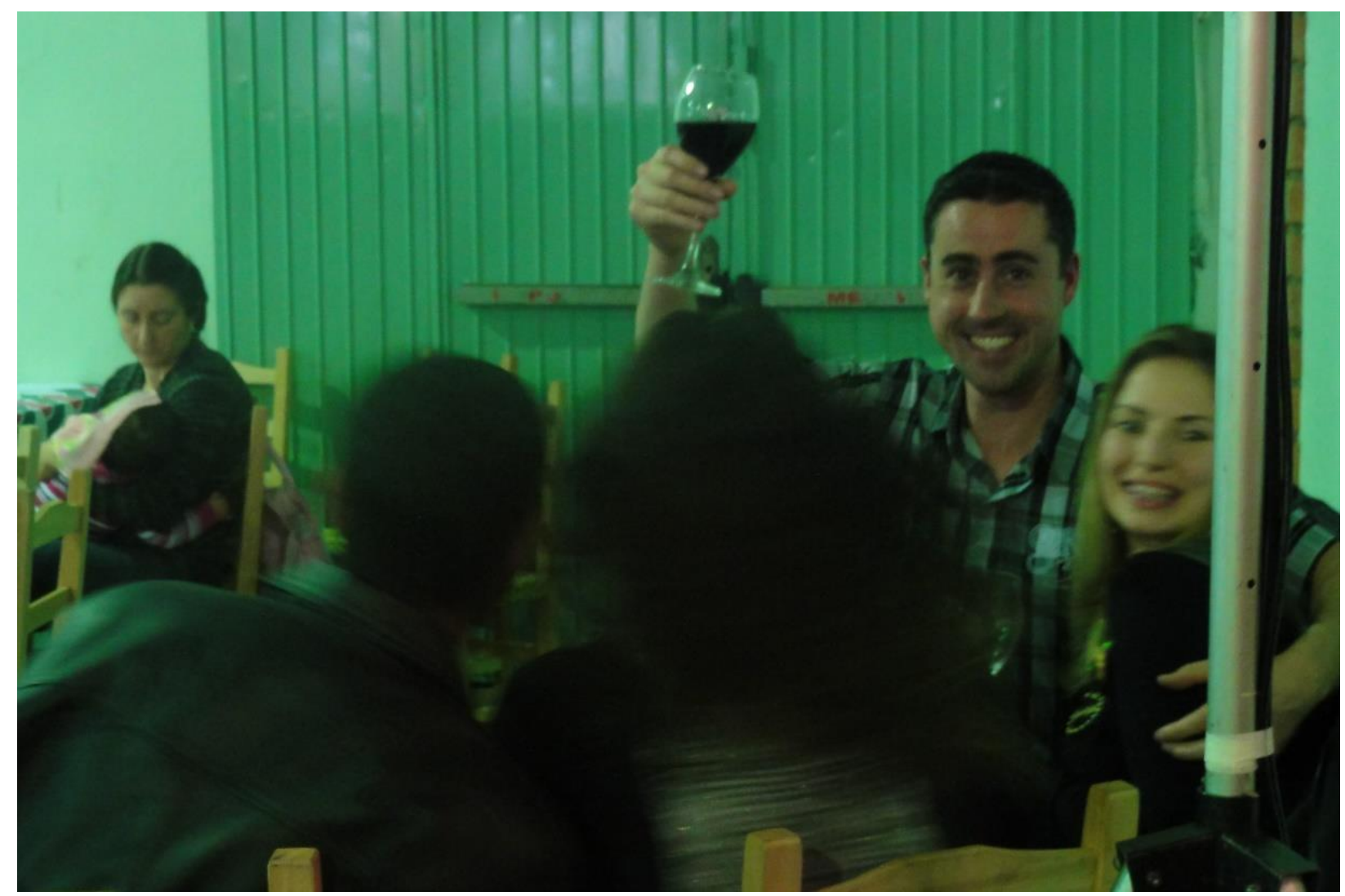

Foto 19: vinho nos ciclos

Fonte: acervo do autor (2014)

Nesta foto podemos observar que o festival de vinho colonial é um ambiente onde é possível encontra pessoas em diversas fases da vida, se de um lado o jovem casal faz um brinde e pousa para o fotógrafo, do outro lado da foto podemos ver uma outra fase da vida onde uma mulher acalenta uma criança no colo. 


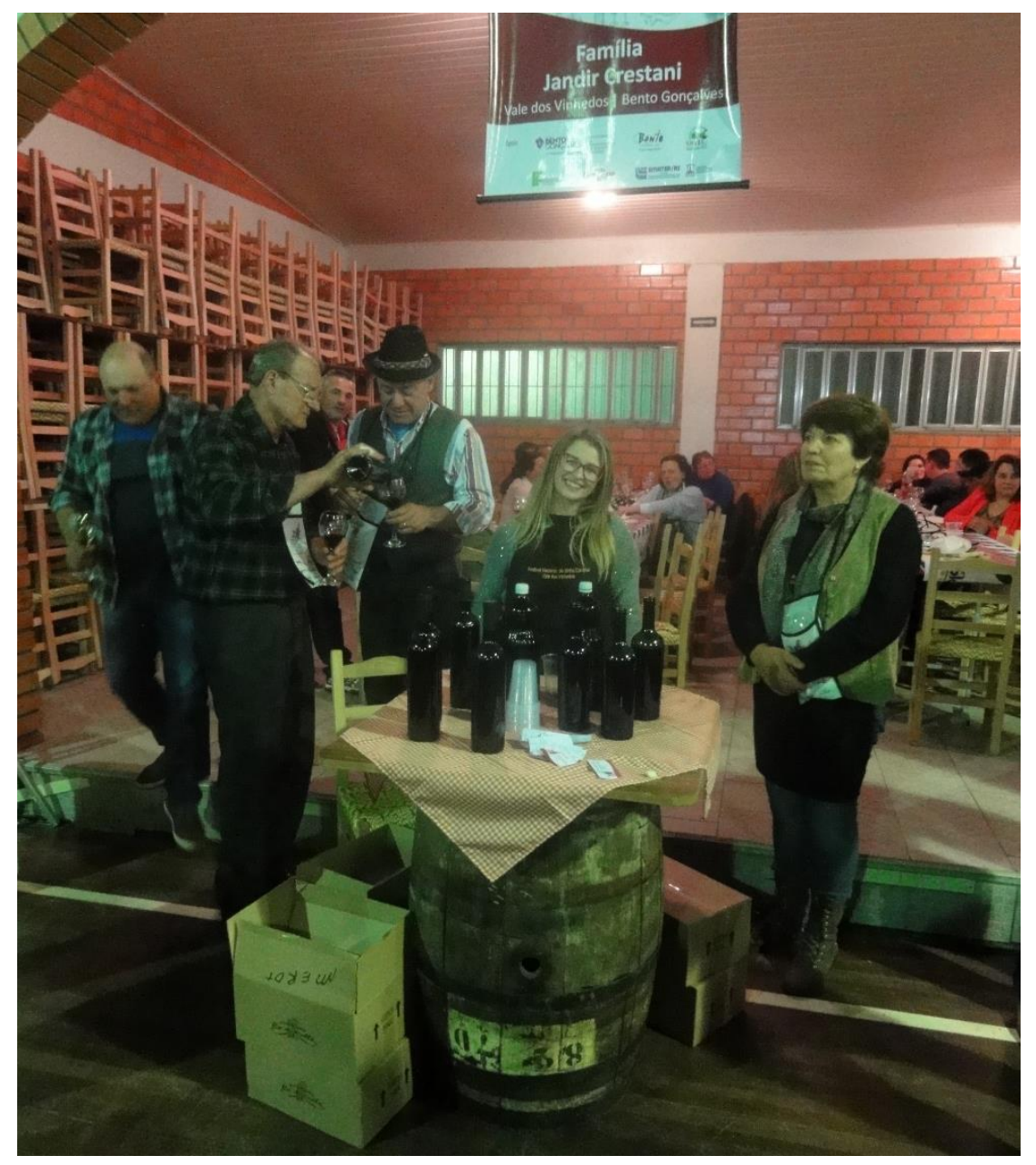

Foto 20: namorada e família

Fonte: acervo do autor (2014)

Nesta foto podemos ver o espaço de exposição dos produtos da família Crestani. O senhor Jandir Crestani servindo vinho ao seu amigo que está vestido com a roupa típica do tirol, a namorada de Tiago Crestani pousando para a foto e vestindo o avental do festival do vinho colonial e a senhora Vilma Crestani observando as imagens do Vale dos Vinhedos que eram projetadas na parede e usando o guarda-taça do festival. 


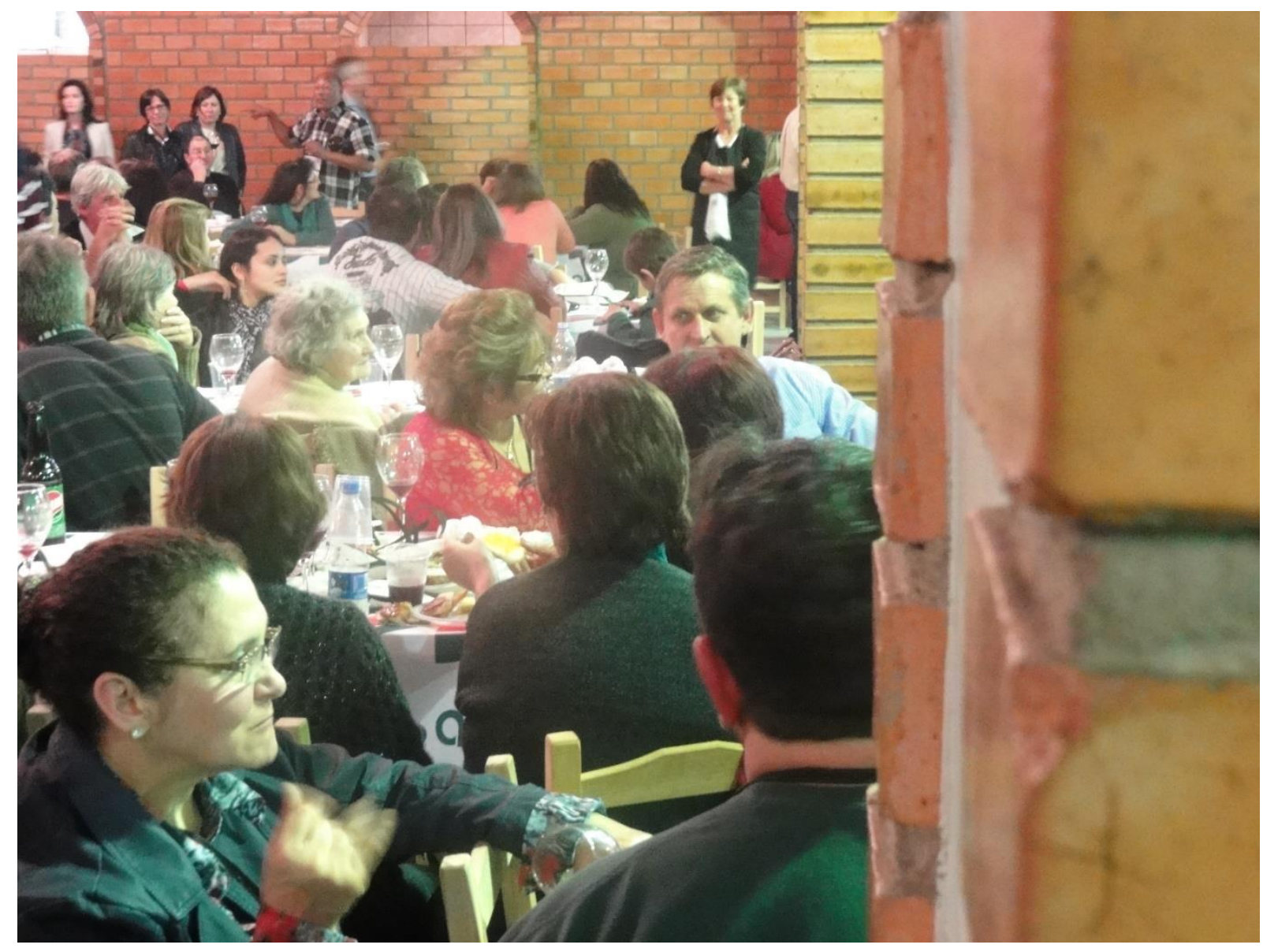

Foto 21: visão interna

Fonte: acervo do autor (2014)

Esta é a visão interna da lateral do galpão. É possível ver nessa fotografia pessoas com diferentes idades, com destaque para a senhora no centro. É possível também identificar algumas pessoas que foram visitadas, como o Pai do produtor Maikon Panizzi de cabelos brancos e se encontra sentado na frente dos técnicos da Emater que estão em pé. É interessante notar que todas as taças que estão sobre as mesas estão vazias, inclusive a taça na frente da senhora de mais idade, demostrando que o vinho colonial é consumido por todas as idades adultas durante as refeições. 


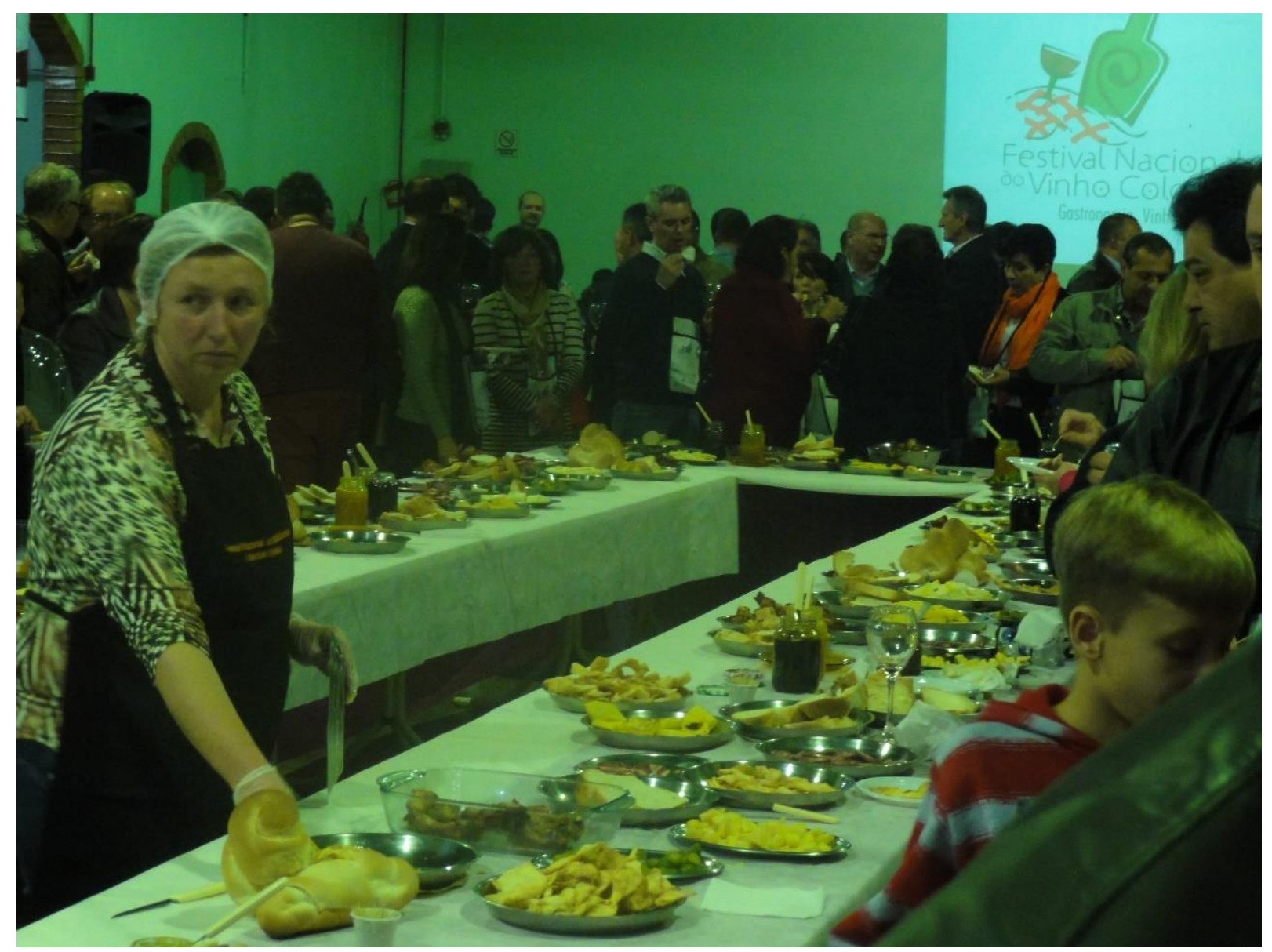

Foto 22: constante fartura na mesa

Fonte: acervo do autor (2014)

A mesa farta e a reposição constante de alimentos chamou a atenção tanto do enoturistapesquisador como do fotógrafo local. É possível notar nessa foto a atenção dada ao manusear os alimentos, pois a senhora que está somente repondo os alimentos está vestida com luvas, touca e avental. Pode-se observar a atenção no rosto da senhora que parece estar observando os próximos pratos que serão repostos.

Oportunamente é possível ver projetado a arte do festival do vinho com o slogan do evento: "FESTINAL NACIONAL DO VINHO COLONIAL: Gastronomia, vinho e alegria" no fundo da foto. É bastante razoável notar que tanto a gastronomia, como vinho e a alegria estão presentes na sequência de fotos que buscam representar o que realmente foi vivenciado no festival. 


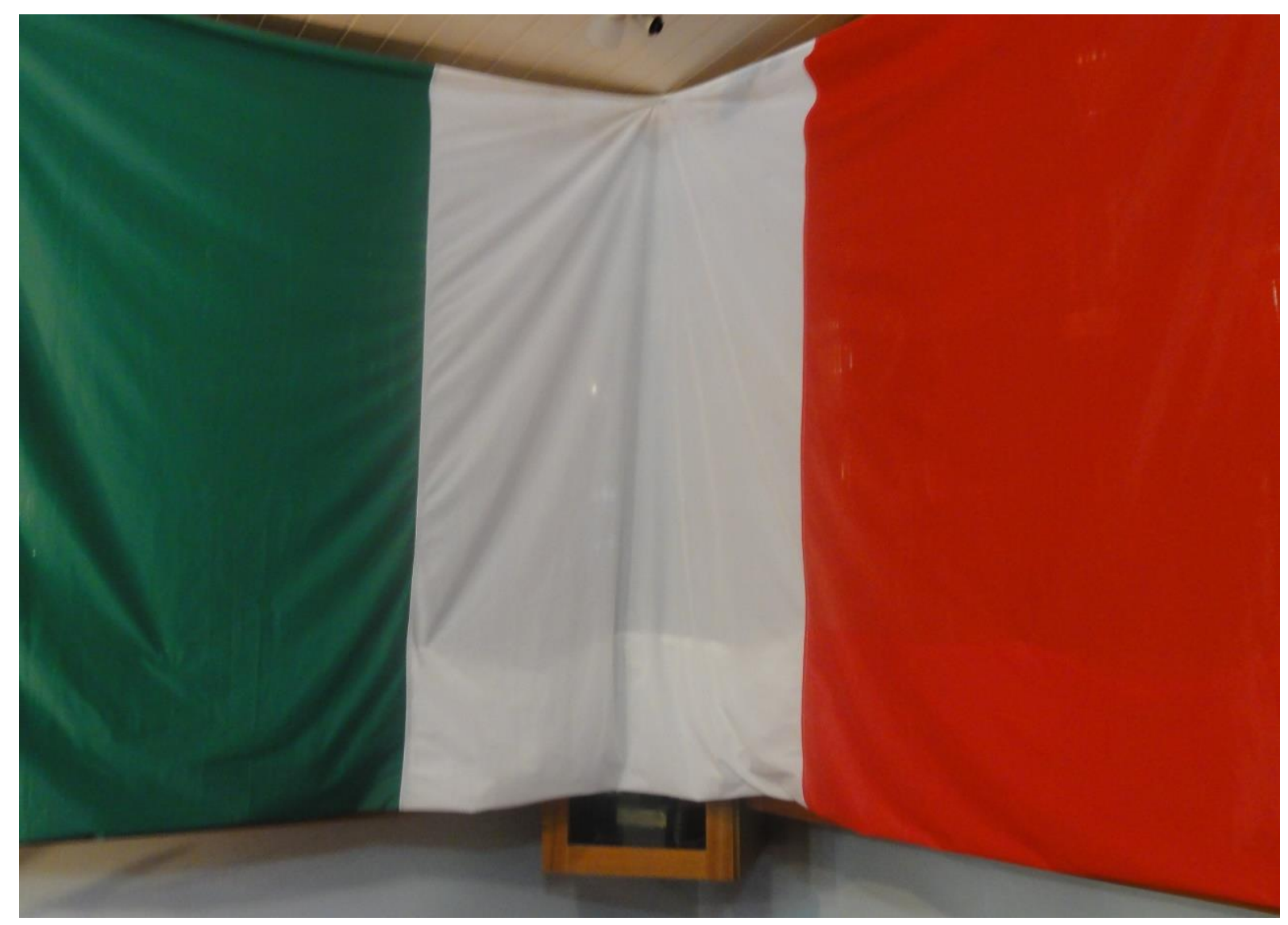

Foto 23: Itália

Fonte: acervo do autor (2014)

Logo na entrada do galpão havia uma grande bandeira italiana medindo aproximadamente 1,50 x 2,5m. No pavilhão havia mais duas outras bandeiras da Itália, uma ao lado do carro de boi e outra no espaço de fomento ao restauro dos casarões do Vale dos Vinhedos. Havia também uma flâmula da região de Trento. Ao todo temos uma relação de quatro bandeiras italianas para uma bandeira do Brasil, uma do Rio Grande do Sul e uma da cidade de Bento Gonçalves.

Diante deste fato seria possível inferir que aquela comunidade tem uma forte ligação e identificação com o país de seus descendentes. É importante observar que a arte feita para o festival do vinho colonial tem as mesmas cores da bandeira da Itália. 


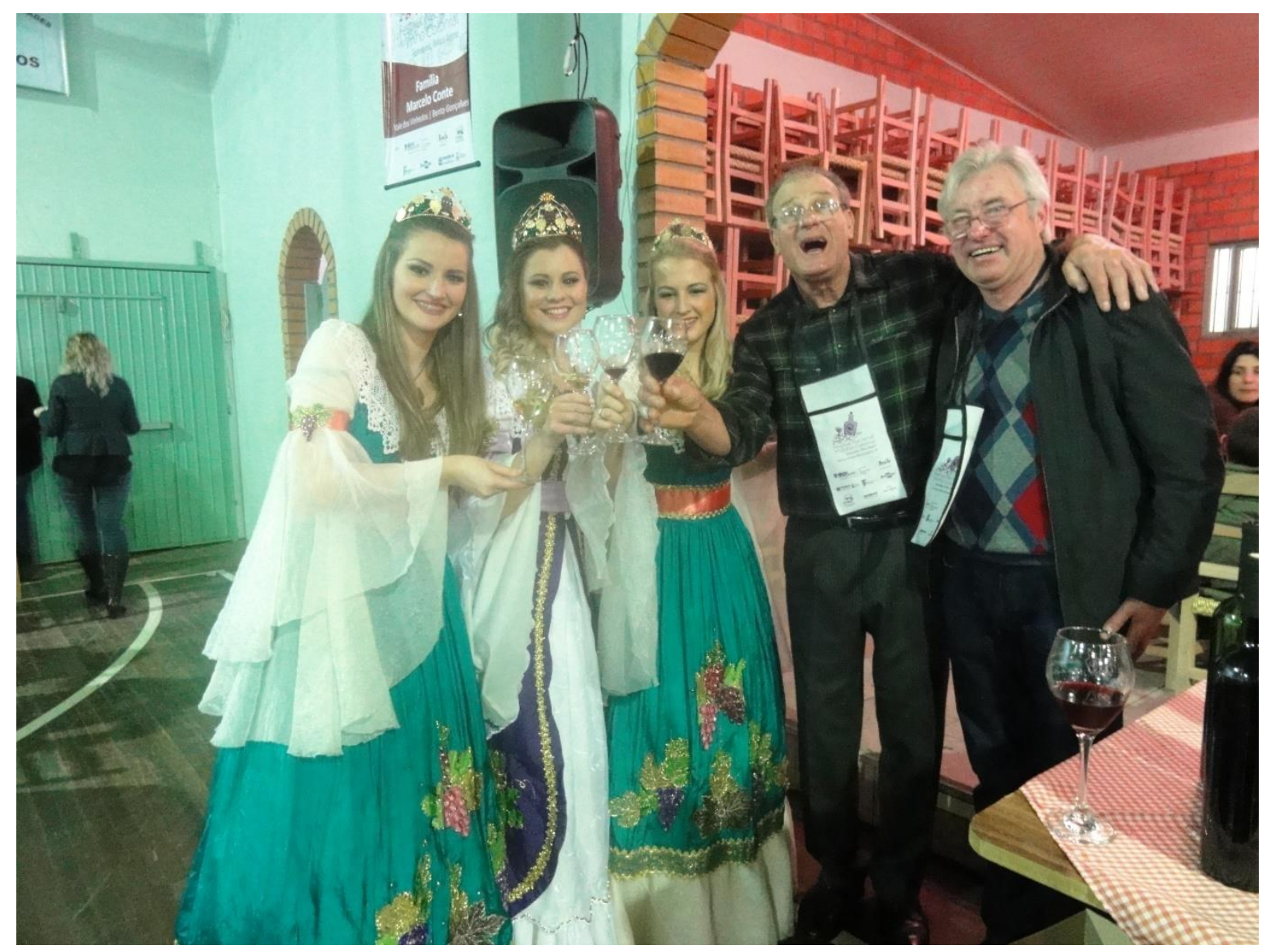

Foto 24: alegria

Fonte: acervo do autor (2014)

A descontração e alegria do produtor Jandir Crestani acompanhado de seu amigo e das princesas e rainha da uva que foram fotografados por Tiago Crestani.

Anualmente são escolhidas duas princesas e uma rainha da uva. Posteriormente ao festival em conversa com alguns produtores fui informado que o concurso de rainha e princesas são avaliados outros aspectos além da questão estética das jovens. Alguns dizem que é avaliado se a candidata sabe "falar bem" e "sabe se comportar", citando o caso de Vanessa Crestani, filha do produtor Jandir Crestani que já foi rainha da uva no ano de 2012.

No entanto, conversando com outros produtores, eles diziam que o concurso de rainha e princesas da uva é ponderado também alguns interesses sociais com o intuito de dar evidência para algumas jovens da comunidade.

Ao analisar as fotografias fica evidente como os olhares sobre um mesmo evento podem ser tão diferentes. É notório que as fotografias feitas sob a perspectiva do enoturista-pesquisador 
mostram informações de aspecto macro, típico de alguém que não pertence àquela comunidade e acaba por deixar-se levar pela perspectiva superficial de alguém que não vivencia e frequenta aquele evento, atentando para aquilo que lhe causa estranhamento como os trajes típicos, coral de músicas italianas, crianças brincando em meio as signos e tradições locais, pessoas que com o consumo do vinho passam a falar italiano, a forma de exposição de cada produtor, a presença de todas as faixas etárias interagindo constantemente entre elas, a abastança de alimentos e vinhos e as formas de perpetuação das tradições.

Já as fotografias feitas por Tiago Crestani que mora na comunidade e conhece de perto toda a movimentação para a elaboração do festival teve outra perspectiva do evento. As fotos feitas por Tiago são dotadas de um discurso que só foi possível compreendê-las depois dos dias de convívio com os produtores e habitantes locais. Em algumas fotos como a das bandeiras e dos signos de identidade locais, foi possível compreender suas mensagens logo no dia posterior, quando Tiago devolveu a segunda máquina fotográfica, mas fotografias como do guarda-taça e da garrafa de suco são fotografias que possivelmente outra pessoa tão próxima do evento e da família Crestani pudesse facilmente ler melhor a imagem, mas essa leitura só foi possível após o convívio e muita conversa com os produtores da região.

\subsection{DESCRIÇÃO DO $2^{\circ}$ FESTIVAL NACIONAL DO VINHO COLONIAL}

O Segundo Festival Nacional do Vinho Colonial foi realizado no "Salão do 8 da Graciema" localizado uma região central do Vale dos Vinhedos e de fácil acesso. Logo na entrada, onde normalmente existem seguranças uniformizados, haviam pessoas da comunidade executando o ofício de receber as pessoas que já tinham o convite ou de conduzi-las ao caixa para comprar os convites.

Dentro do salão fui convidado a retirar minha taça e o porta-taça que foi oferecido como lembrança do evento, numa mesa ao lado da porta, como mostra a foto 42. No dia seguinte à festa fiquei sabendo que os últimos convidados que entraram na festa não receberam a taça do festival. Os produtores e organizadores do festival atribuíram ao fato de algumas pessoas terem entrado no festival sem terem comprado suas entradas, pois estariam à trabalho acompanhando alguns políticos que estavam presentes. Os organizadores disseram que não haveria problema algum em deixar essas pessoas entrarem, mas segundo a conversa que presenciei entre os produtores que ajudaram na organização: “a gente esperava que eles não fossem abusar. Era fotógrafo, assessores, apoiadores de campanha.... Daí criava um clima chato de ficar barrando 
essas pessoas. Entrou um monte de pessoas sem pagar e ainda pegaram as taças que seriam das pessoas que chegaram mais tarde.”

Ficou claro que havia a presença de alguns políticos, pois na hora que estava tirando uma foto de um programa de apoio ao restauro aos casarões do Vale dos Vinhedos (Foto 25), o enoturista-pesquisador foi solicitado por um dos organizadores, de maneira discreta, que tirasse a foto do prefeito com os banners do programa, como pode ser visto na foto 26 . Durante a festa foi feito um rápido pronunciamento por parte de um candidato que ao final de sua fala de aproximadamente três minutos não houve aplauso ou qualquer demonstração de apoio dos presentes. Haviam pessoas entregando material de propaganda política do lado de fora no salão (Foto 27) e alguns apoiadores dos candidatos que estavam usando adesivos e usufruindo da entrada grátis no evento com as taças e apoio de taças do evento, como foi apontado pelos organizadores e pode ser visto na foto 12 .

No dia seguinte fui informado que agentes do departamento de trânsito da região chegaram a passar no festival do vinho colonial, quando questionados por um dos organizadores se haveria blitz da lei seca os agentes disseram que pelo o que estavam vendo, as pessoas estavam todas sob controle e que não havia necessidade. Um dos organizadores perguntou se os agentes aceitariam uma taça de vinho colonial, eles agradeceram, mas aceitaram um copo de suco colonial.

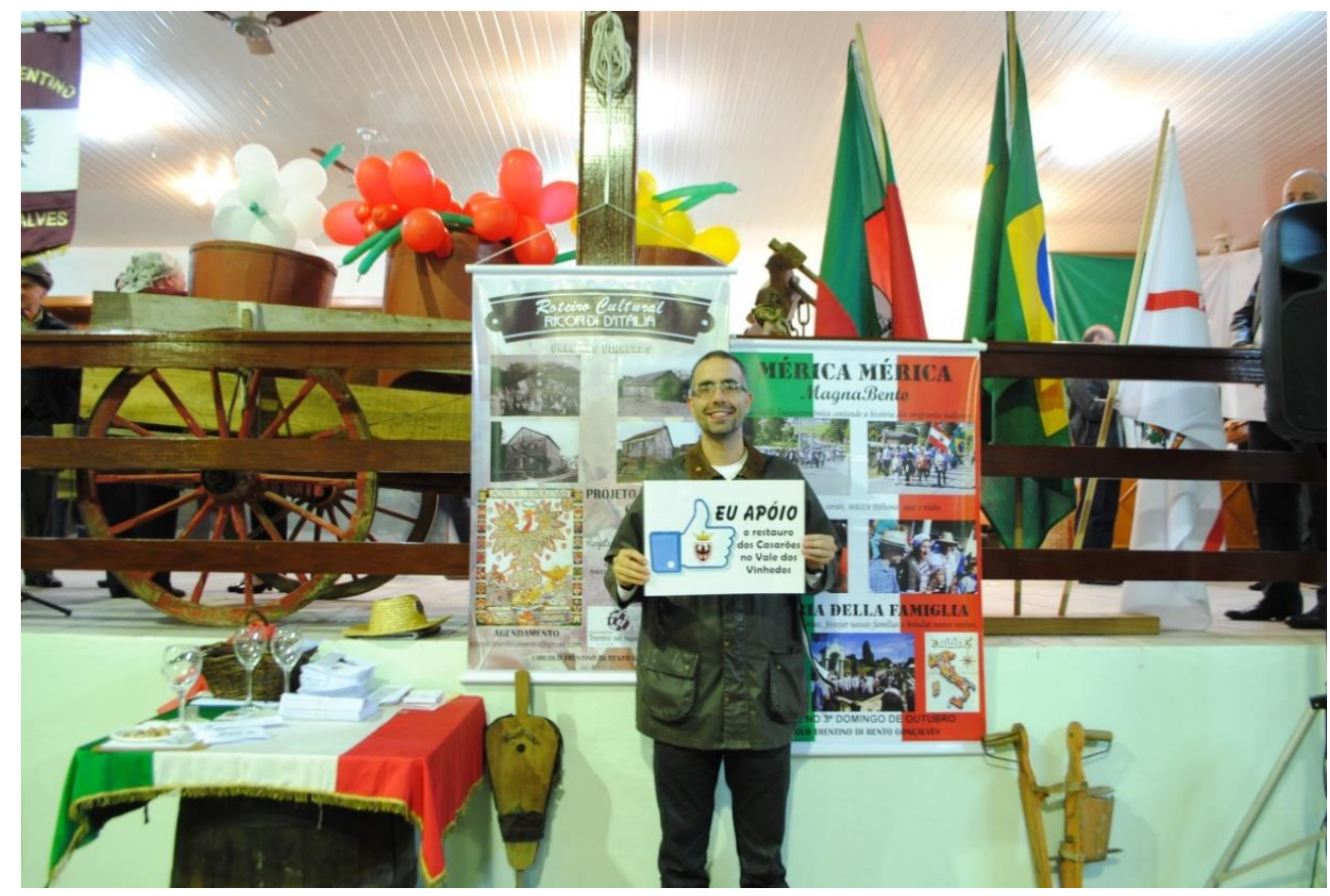

Foto 25: Enoturista-pesquisador apoiando o restauro de casarões do Vale dos Vinhedos Fonte: acervo do autor (2014) 


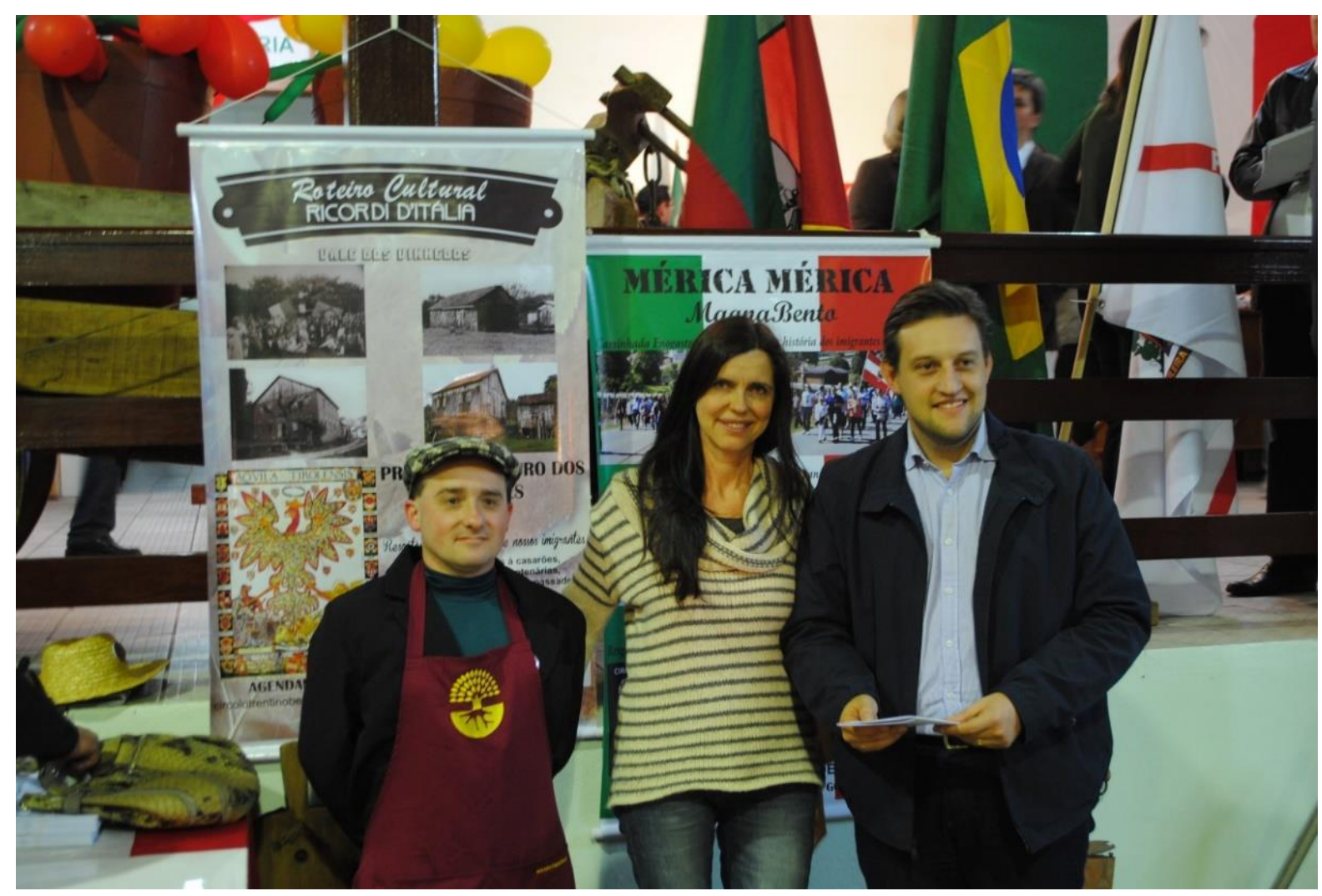

Foto 26: Sandro Giordani e prefeito de Bento Gonçalves apoiando a causa cultural do Vale dos Vinhedos. Fonte: acervo do autor (2014)

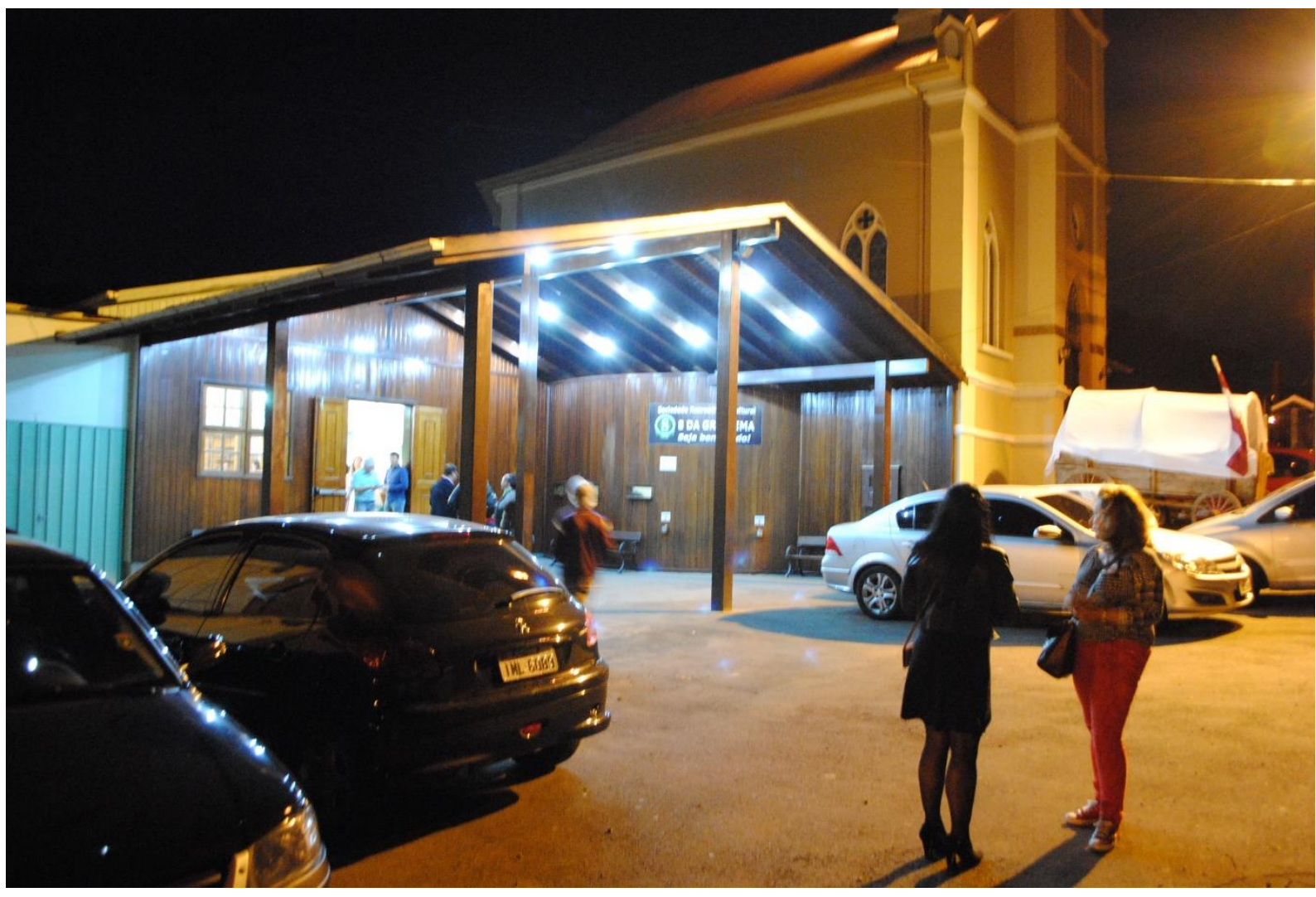

Foto 27: entrega de material eleitoral na frente do salão

Fonte: acervo do autor (2014) 
Logo no início do festival, observou-se que haviam algumas pessoas vestidas com trajes típicos. Algumas senhoras com vestidos e lenços na cabeça e senhores com roupas e chapéus característicos da região do Tirol. A região do Tirol é uma região que abrange parte da Áustria e região norte da Itália. A região do Tirol ao norte da Itália é justamente a região autônoma Trentino-Aldo Ágide (Trentino-Südtirol) de onde são oriundos a maioria dos descendentes de italianos do Vale dos Vinhedos. Ao analisar as fotos feitas tanto pelo enoturista-pesquisador, como pelo produtor Tiago Crestani, notou-se que somente um objeto foi fotografado por ambas as óticas, que foi a flâmula do Circolo Trentino (Foto 28).

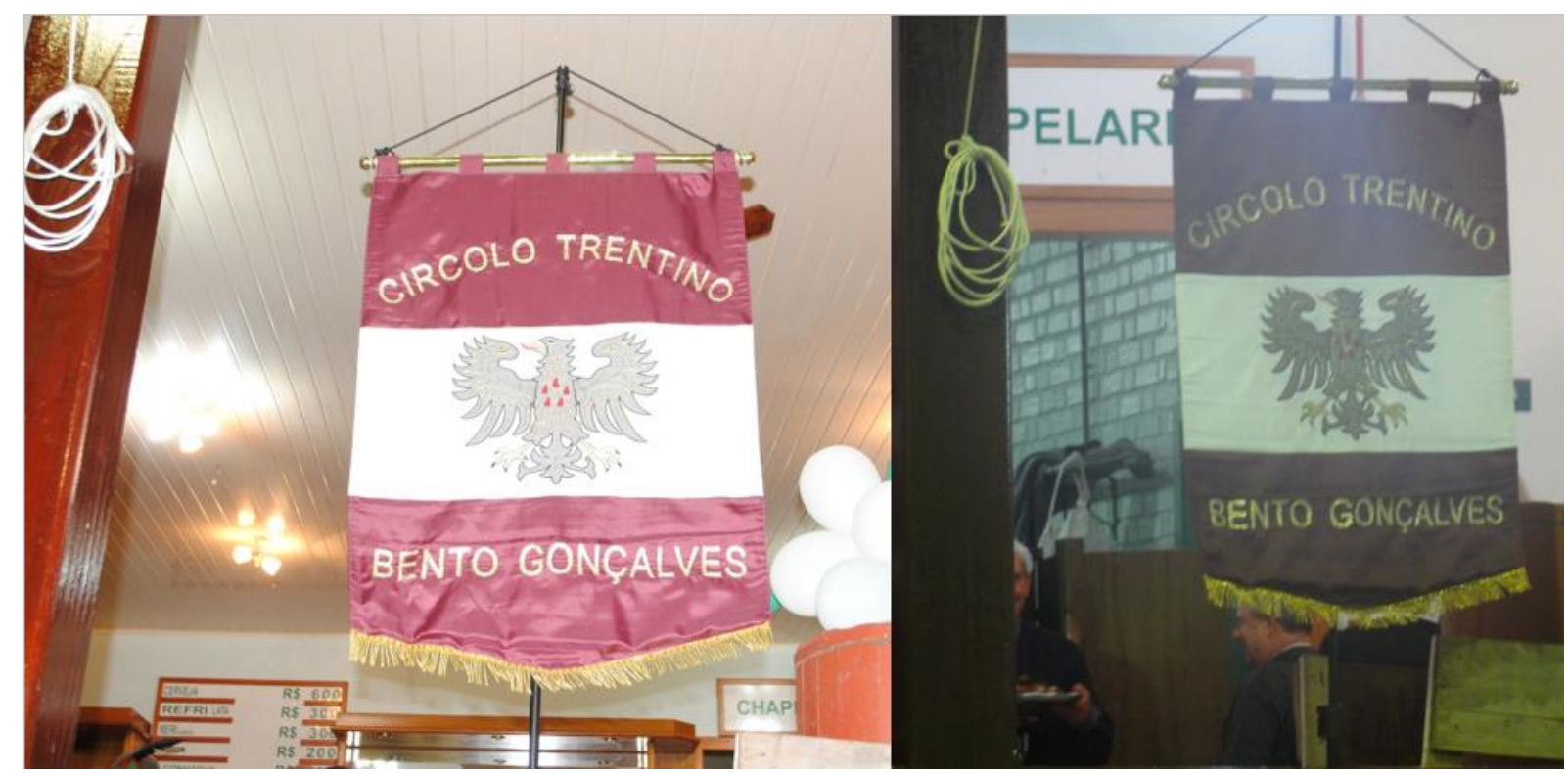

Foto 28: Circolo Trentino: foto do enoturista-pesquisador e produtor, respectivamente.

Fonte: acervo do autor (2014)

É notório que a comunidade da região do Vale dos Vinhedos é muito ligada à cultura italiana, o coral que se apresentou com taças de vinho a mão, como mostra na foto 07 , cantava músicas na língua italiana e algumas em dialeto trentino. Uma observação muito interessante feita com o passar do tempo no festival foi que as pessoas depois de terem bebido algumas taças de vinho começaram a falar em italiano. No início da festa não se ouvia ninguém falando em italiano, com o decorrer da festa as pessoas ali presentes tomando vinho colonial, comendo comidas típicas das colônias, ouvindo e cantando músicas italianas deixavam transparecer suas raízes italianas e frequentemente ouvia-se pessoas conversando em italiano ou bradando junto com o coral. 
Mesmo em se tratando do festival do vinho colonial, haviam muitas crianças e adolescentes na festa. O público mais jovem usufruía do suco colonial (Foto 16), a mesa farta (Fotos 09 e 22), com as apresentações de música e coral (07 e 10) e com a presença de outras crianças (Foto 11).

\subsection{LEI DOS VINHOS ARTESANAIS: ANÁLISE DAS DIFERENÇAS ENTRE A} PROPOSTA DE LEI E A LEI APROVADA, ANALISE DAS NOTAS DE VETOS DO MINISTÉRIO DA FAZENDA

É importante conceituar qual o significado e restrições adotadas para o uso do termo vinho colonial. Iniciando com a conceituação dada pela lei ${ }^{\circ} 12.959 / 2014$, é possível verificar que a legislação traça rumos gerais sobre o que seria caracterizado como vinho colonial. A lei trata que o vinho colonial é o vinho produzido por agricultor familiar ou empreendedor familiar rural, elaborado de acordo com as características culturais, históricas e sociais da vitivinicultura desenvolvida por aqueles que estejam submetidos à Política Nacional da Agricultura Familiar e Empreendimentos Familiares Rurais, desde que observados alguns requisitos e limites estabelecidos como:

$\S 1$ o v vinho produzido deve ser elaborado com o mínimo de $70 \%$ (setenta por cento) de uvas colhidas no imóvel rural do agricultor familiar e na quantidade máxima de 20.0001 (vinte mil litros) anuais.

§ 20 A elaboração, a padronização e o envasilhamento do vinho produzido deve ser feito exclusivamente no imóvel rural do agricultor, adotando-se os preceitos das Boas Práticas de Fabricação e sob a supervisão de responsável técnico habilitado.

§ 3o A comercialização do vinho deverá ser realizada diretamente com o consumidor final, na sede do imóvel rural onde foi produzido, em estabelecimento mantido por associação ou cooperativa de produtores rurais ou em feiras da agricultura familiar.

Desta forma, a lei não conceitua o que vem a ser um vinho colonial, mas faz restrições do que poderia ser enquadrado como vinho colonial. Fazendo restrições de ordem qualitativa e quantitativa como pela quantidade de litros produzidos, porcentagem mínima de uvas oriundas da propriedade, o agricultor deve estar dentro dos parâmetros adotados pela agricultura familiar e a forma de produção deve respeitar as características culturais, históricas, sociais da vitivinicultura. 
Em conversa como Gerson Luís Ben, chefe do gabinete do deputado Pepe Vargas, que propôs a lei, o mesmo foi questionado quanto às características dos vinhos coloniais. Inicialmente foi perguntado se os vinhos caracterizados como vinhos coloniais seriam necessariamente vinhos de variedades americanas. Gerson afirmou que não necessariamente, apesar da maior parte dos vinhos produzidos e comercializados informalmente serem vinhos oriundos de variedades americanas. O mais importante segundo o chefe de gabinete seria a forma de produção.

Seguindo ainda pela linha dos relatos presenciados, na visita enoturística à vinícola Torcello, o proprietário Rogério Valduga fez uma afirmação muito interessante sob o ponto de vista da enocultura brasileira. Segundo Rogério, foram as importações de vinhos estrangeiros que fizeram com que a enocultura brasileira se desenvolvesse para o que é atualmente. Rogério afirma que os vinhos importados de qualidade acabaram gerando um padrão de consumo de vinho mais exigente, obrigando os produtores de vinhos nacionais a produzirem vinhos com uvas europeias e a produzirem vinhos secos. Concluindo o relato, Rogério afirma que se não fosse pelo gosto adquirido pelos vinhos importados o brasileiro ainda estaria tomando vinhos de variedade americanas.

Já Vander Valduga faz alguns questionamentos sobre o que vem a ser um vinho típico da região, qual vinho é produzido pelos nativos e consumido por eles? Partindo por essas questões, é oportuno analisar a constituição dessa região e seus habitantes. Na pesquisa realizada por Valduga (2008), ele afirma que a região da Serra Gaúcha onde está localizado o Vale dos Vinhedos, trata-se de uma região habitada por muitos descendentes de imigrantes italianos, e juntamente com outras formas de expressão cultural, o hábito de cultivar uvas e beber vinho é representativo por quase toda a totalidade dessas famílias que produzem seu próprio vinho. Devemos levar em consideração que os agricultores rurais, ao produzirem os vinhos para seu consumo, produzem vinhos comuns, mais leves para o cotidiano. E a partir dessa linha de pensamento, o autor afirma que o vinho típico produzido e consumido pelos habitantes da Serra Gaúcha é o vinho de variedades americanas.

Levando em consideração os depoimentos de todos os produtores visitados que afirmam que os vinhos secos produzidos pelas grandes vinícolas no Vale dos Vinhedos não representam os vinhos dos colonos e descendestes italianos, somado ainda as citações de Rogério e Vander Valduga (2008) além dos estudos sobre o Vale dos Vinhedos e viticultura no Brasil, é possível inferir que os vinhos que representam aquela população e que alegravam as mesas das refeições 
da colônia e que são consumidos cotidianamente pelos produtores coloniais são os vinhos de produção colonial.

Sendo assim, conceitua-se o termo "vinho colonial" para esse trabalho o vinho que é elaborado sob a dinâmica dos produtores coloniais, não havendo restrições de variedades, apesar da maior parte dos vinhos coloniais serem oriundos de uvas de variedades américas. Não se faz restrições dos recipientes onde são acondicionados os vinhos, apesar da maioria dos produtores produzirem seus vinhos com barris de madeira. A única restrição adotada será a limitação de volume de vinho produzido de 20.000 litros/ano, conforme adotado na lei do vinho colonial.

A lei dos vinhos coloniais foi aprovada a partir do projeto de lei $n^{\circ} 2.693$ de 2011 , proposta pelo Deputado e atual ministro do Desenvolvimento Agrário, Pépe Vargas. No entanto, o projeto de lei sofreu vetos parciais, de maneira que será possível observar as diferenças entre diversos aspectos da proposta de lei e a forma que a lei foi aprovada.

\begin{tabular}{|l|l|l|}
\hline \multicolumn{1}{|c|}{ Proposta de lei } & & \multicolumn{1}{|c|}{ Lei nº 12.959 (aprovada) } \\
\hline Produção máxima de até 25.000 litros/ano. & $\neq$ & Produção máxima de até 20.000 litros/ano. \\
\hline Produzido por Agricultor Familiar. & $=$ & Produzido por Agricultor Familiar. \\
\hline $\begin{array}{l}\text { Produção de acordo com as características e } \\
\text { peculiaridades culturais, históricas e de cunho } \\
\text { social da agricultura familiar. }\end{array}$ & $=$ & $\begin{array}{l}\text { Produção de acordo com as características culturais, } \\
\text { históricas e sociais da vitivinicultura desenvolvida } \\
\text { por aquele que atenda às condições da Lei } \\
n^{\circ} 11.326 / 2006 \text { (Lei da Agricultura Familiar). }\end{array}$ \\
\hline $\begin{array}{l}\text { A Elaboração, a padronização e o } \\
\text { envasilhamento do vinho produzido deve ser } \\
\text { feito exclusivamente no imóvel rural do } \\
\text { agricultor familiar, adotando-se os preceitos } \\
\text { das Boas Práticas de Fabricação e sob a } \\
\text { supervisão de responsável técnico habilitado. }\end{array}$ & $=$ & $\begin{array}{l}\text { A Elaboração, a padronização e o envasilhamento do } \\
\text { vinho produzido deve ser feito exclusivamente no } \\
\text { imóvel rural do agricultor familiar, adotando-se os } \\
\text { preceitos das Boas Práticas de Fabricação e sob a } \\
\text { supervisão de responsável técnico habilitado. }\end{array}$ \\
\hline $\begin{array}{l}\text { A comercialização deve ser restrita à } \\
\text { propriedade rural familiar, ou estabelecimento } \\
\text { mantido por associação de produtores, sendo } \\
\text { permitida apenas a venda ao consumidor final. }\end{array}$ & $\begin{array}{l}\text { A comercialização do vinho produzido por agricultor } \\
\text { familiar ou empreendedor familiar rural deverá ser } \\
\text { realizada diretamente com o consumidor final, na } \\
\text { sede do imóvel rural onde foi produzido, em } \\
\text { estabelecimento mantido por associação ou }\end{array}$ \\
\hline
\end{tabular}




\begin{tabular}{|c|c|c|}
\hline & & $\begin{array}{l}\text { cooperativa de produtores rurais ou em feiras da } \\
\text { agricultura familiar. }\end{array}$ \\
\hline $\begin{array}{l}\text { "A proposição intenta que a comercialização } \\
\text { do vinho colonial seja feita por meio de nota } \\
\text { do talão do produtor rural" incidindo apenas } \\
2,5 \% \text { de imposto. }\end{array}$ & $\neq$ & (VETADO) \\
\hline $\begin{array}{l}\text { Parâmetros de Rotulagem: denominação de } \\
\text { vinho colonial, sua origem (nome do produtor } \\
\text { e da propriedade), n }{ }^{\circ} \text { de Declaração de } \\
\text { Aptidão ao Programa de Fortalecimento da } \\
\text { Agricultura Familiar (Pronaf) e informações } \\
\text { sobre as características do produto. }\end{array}$ & $=$ & $\begin{array}{l}\text { Parâmetros de Rotulagem: } \\
\text { I - a denominação de "vinho produzido por agricultor } \\
\text { familiar ou empreendedor familiar rural", "vinho } \\
\text { colonial" ou "produto colonial"; } \\
\text { II - a indicação do agricultor familiar ou } \\
\text { empreendedor familiar rural, com endereço do } \\
\text { imóvel rural onde foi produzido; } \\
\text { III - o número da Declaração de Aptidão ao Pronaf } \\
\text { fornecida por entidade autorizada pelo Ministério do } \\
\text { Desenvolvimento Agrário - MDA; } \\
\text { IV - outras informações exigidas ou autorizadas } \\
\text { nesta Lei e em seus regulamentos. }\end{array}$ \\
\hline $\begin{array}{l}\text { Desobriga os agricultores familiares que } \\
\text { produzem até } 2.000 \text { litros/ano de vinho para } \\
\text { consumo próprio, de cumprirem as exigências } \\
\text { acima. }\end{array}$ & $\neq$ & (VETADO) \\
\hline
\end{tabular}

Quadro 01: diferenças entre a proposta e lei aprovada

Posteriormente, obteve-se a nota técnica que embasou o veto do projeto de lei no ministério da fazenda. A nota técnica justifica o veto da impossibilidade da comercialização com o talão do produtor fiscal pois, segundo a análise:

a comercialização por meio da emissão da nota do talão do produtor rural, negligencia o fato do produtor rural pessoa física fabricante do vinho colonial deve atender também aos dispositivos constantes da legislação do Imposto sobre Produtos Industrializados (IPI), dentre eles os que tratam da obrigatoriedade de emissão de nota fiscal. 
É interessante observar que a aprovação da comercialização com a emissão da nota do talão do produtor rural esbarrou numa premissa tributária de âmbito nacional que é a taxação do Imposto de Produto Industrializado (IPI). A taxação do IPI não caberia aos vinhos coloniais uma vez que não são produtos industrializados. Os vinhos coloniais são produtos artesanais que haveria a possibilidade de fazer a comercialização direta entre produtor agrícola e consumidor final, justamente, dispensando a dinâmica vigente da industrialização. Seria possível questionar o veto, uma vez que os vinhos coloniais são produzidos de maneira colonial ou artesanal. Conforme a descrição da lei, o vinho colonial "é a bebida elaborada de acordo com as características culturais, históricas e sociais da vitivinicultura desenvolvida...”

\subsection{O LEGADO DO TRABALHO COLONIAL}

As videiras americanas, Vitis labrusca e Vitis bourquina, são agronomicamente mais resistentes que as videiras europeias Vitis vinífera (SELDON, 2001). As variedades americanas são plantas mais rústicas e apresentam maior resistência contra doenças, principalmente doenças fúngicas e viróticas. Segundo Pebayle (1973), os colonos escolheram variedades rústicas de origem americana e simultaneamente bem adaptadas às condições climáticas da região e resistentes a "Philloxera", doença que acabou com boa parte de vinhedos europeus. O autor cita ainda que inicialmente foram plantadas muitas videiras americanas da variedade Isabel e Herbemont e algumas variedades híbridas europeias, principalmente de origem italiana como Moscatel, Barbera, Peverella e Trebiano, no entanto, existe um dissenso quanto à afirmação da preferência dada por uvas italianas, pois outros autores comungam da ideia de que as uvas plantadas pelos colonos italianos foram obtidas por meio de troca entre colonos alemães, pois as mudas trazidas pelos italianos secaram ou foram mal acomodadas durante a viagem (DE BONI E COSTA, 1979, apud VALDUGA, 2007) e Dalcin (2008).

Inicialmente os viticultores da região não tinham interesse em cultivar as videiras europeias, pois as videiras americanas propiciavam alto rendimento e exigem menos cuidados que as variedades europeias, também chamadas de variedades finas.

Basicamente todas as videiras europeias comerciais no mundo são enxertadas sobre cavalos de videiras americanas pelo fato de serem mais resistentes e rústicas. Pode parecer estranho para algumas pessoas que desconhecem algumas técnicas agronômicas, mas a enxertia é uma técnica antiga e muito eficaz, onde almeja-se obter qualidades de espécies distintas sob uma mesma planta. No caso, as videiras europeias que tem como qualidade a produção de frutos 
com maior concentração de açúcares e a videira americana que tem como qualidade sua rusticidade e resistência às doenças de solo. Segundo Pebayle (1973), trata-se de uma prática que "mostra bem que os colonos aprenderam a conhecer a e conciliar as diferentes qualidades de suas linhagens". É importante ressaltar que essa técnica não tem nenhuma relação com a técnicas de modificação genética para produção de plantas transgênicas.

Basicamente a enxertia da videira é feita da seguinte forma: Como a espécie que tem maior interesse pelas partes inferiores é a videira americana, secciona-se a parte superior do caule e faz-se um corte dividindo a parte inferior do caule corte em duas partes. Depois é feito um corte em "V" no galho da videira europeia, que tem interesse por sua parte superior. O corte feito no galho da videira europeia deve ter a mesma espessura do caule da videira americana. O corte do galho da videira europeia é colocado por dentro e em contato com o corte feito no caule na videira americana e são fixados um sobre o outro, como mostra a figura 04. Como a videira americana e europeia são espécies botanicamente próximas, do mesmo gênero, essas espécies compartilham de dimensões e enzimas similares que torna possível essa relação simbiótica. A parte inferior da planta continuará com as características de resistência da videira americana e a parte superior da planta com as características dos frutos da videira europeia.

Esse processo é feito em cada videira na maioria dos parreirais de produção comercial de uvas europeias. Já produtores de uvas americanas não necessitam de fazer a enxertia.

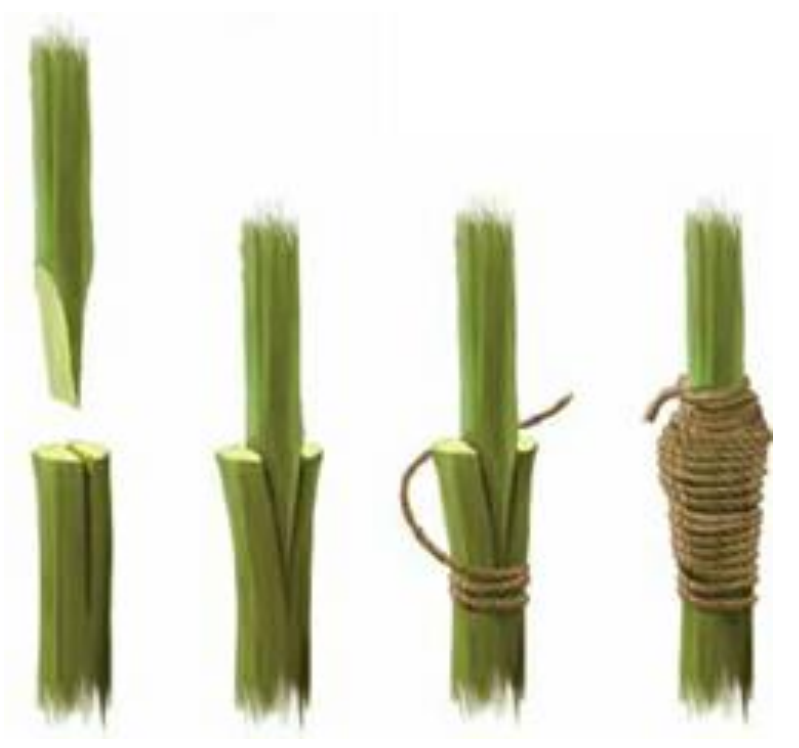

Figura 04: enxertia de videiras

Fonte: blogspot.sereisumasocarne.com.br 
O autor Raymond Pebayle (1973) cita que é comum ver enxertos sendo feitos de maneira totalmente empírica, principalmente quando existe a troca entre vizinhos de porta enxerto (cavalo) e enxertos. O autor afirma ainda que o enxerto em "fenda completa", como é demostrada na imagem anterior, é feito junto ao solo, sobre tronco de dois anos que são em seguida recobertos com terra para proteger do "ardor do sol".

Essa forma de enxertia retratada pelo autor não é amplamente utilizada atualmente, pelo fato de aumentar possíveis contaminações fúngicas e bacterianas, no entanto, essa técnica foi observada pelo enoturista-pesquisador durante o período das visitas, como pode ser visto nas fotografias a seguir.

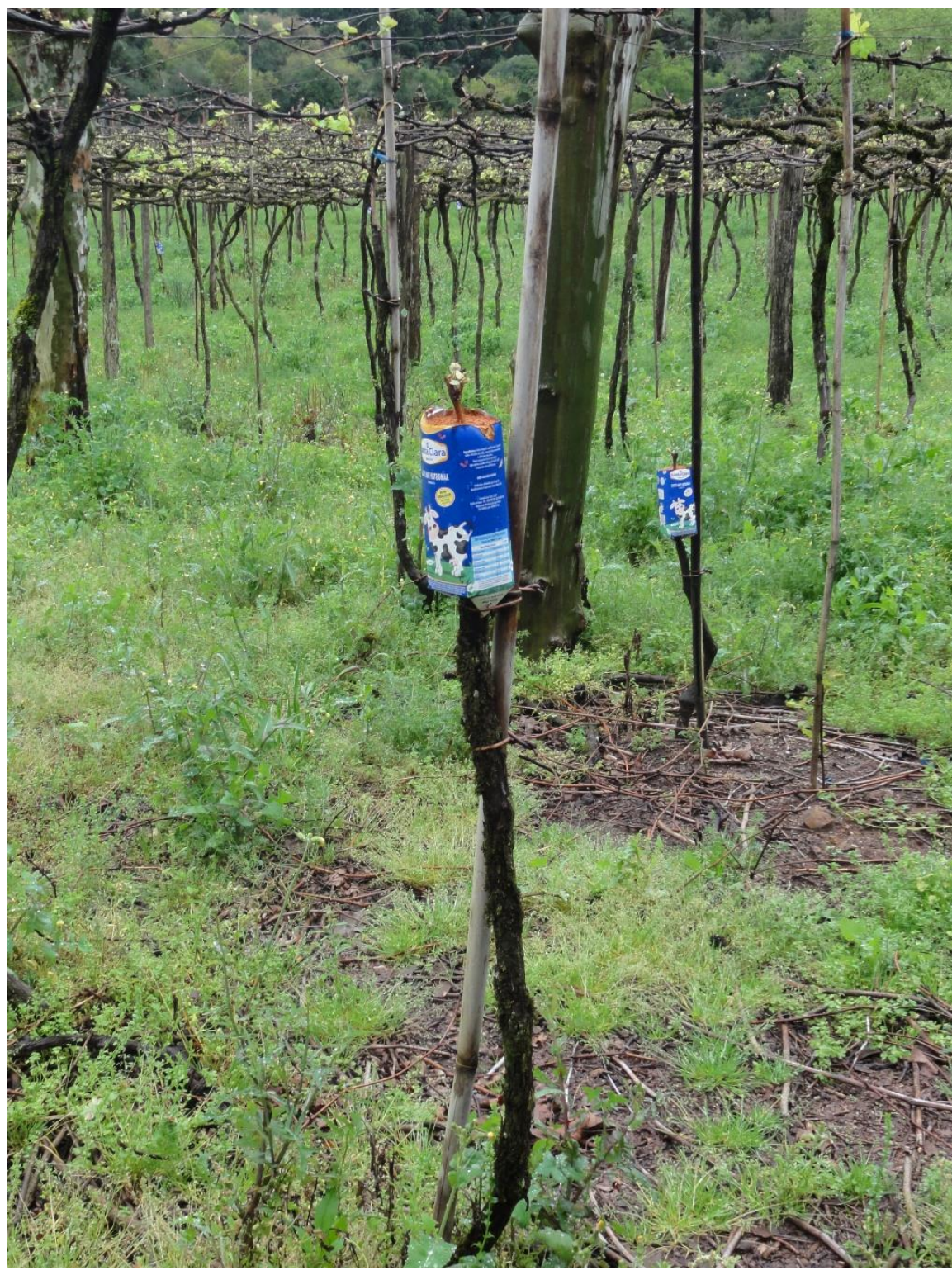

Foto 29: enxertias em fenda completa envoltas de solo em campo no Vale dos Vinhedos Fonte: acervo do autor (2014) 


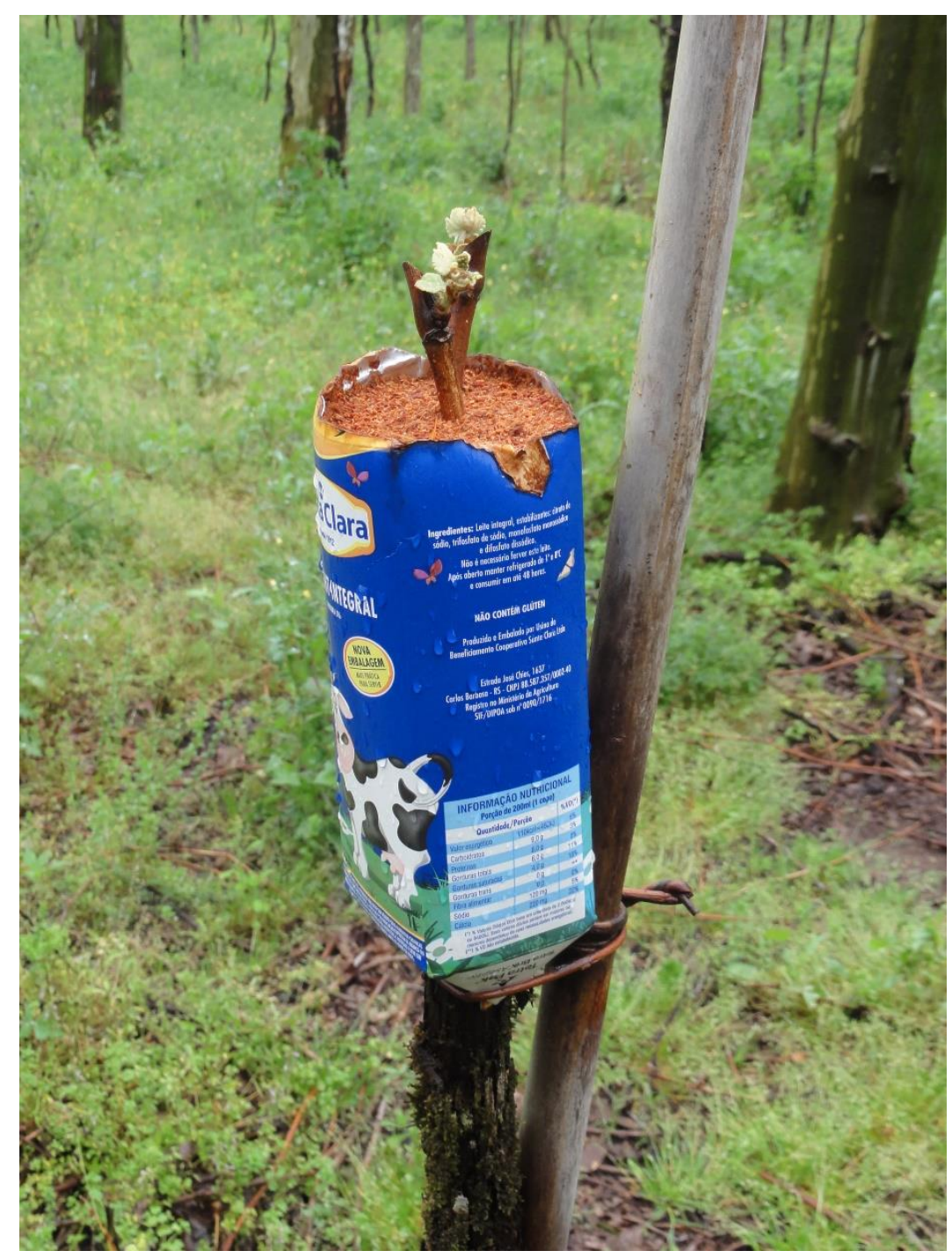

Foto 30: detalhe da enxertia realizada conforme citação de Pébayle (1973).

Fonte: acervo do autor (2014)

As videiras americanas são espécies que tendem a vegetar mais, produzir maior quantidade de frutos e serem menos exigentes nutricionalmente, no entanto o fato de ter uma maior produtividade acaba por diminuir a concentração de açúcares e a qualidade do sumo dessas uvas.

Pebayle (1973) cita que as variedades "Isabel e Hebemont, são realmente, videiras vigorosas que suportam podas muito prolongadas". O autor atenta ainda para "uma arte bem mediterrânea" de condução dos vinhedos que pode ser feita de maneira bem original, substituindo os pilares laterais das linhas por rochas talhadas (Foto 31) ou plantações de plátano - Platanus sp. (Foto 32). O autor cita ainda que os plátanos "absorvem literalmente os arames 
amarrados em seus troncos" (Foto 33), e essas técnicas são feitas principalmente onde o solo é pouco profundo para fixar os esticadores de arame e foram observadas na atualidade.

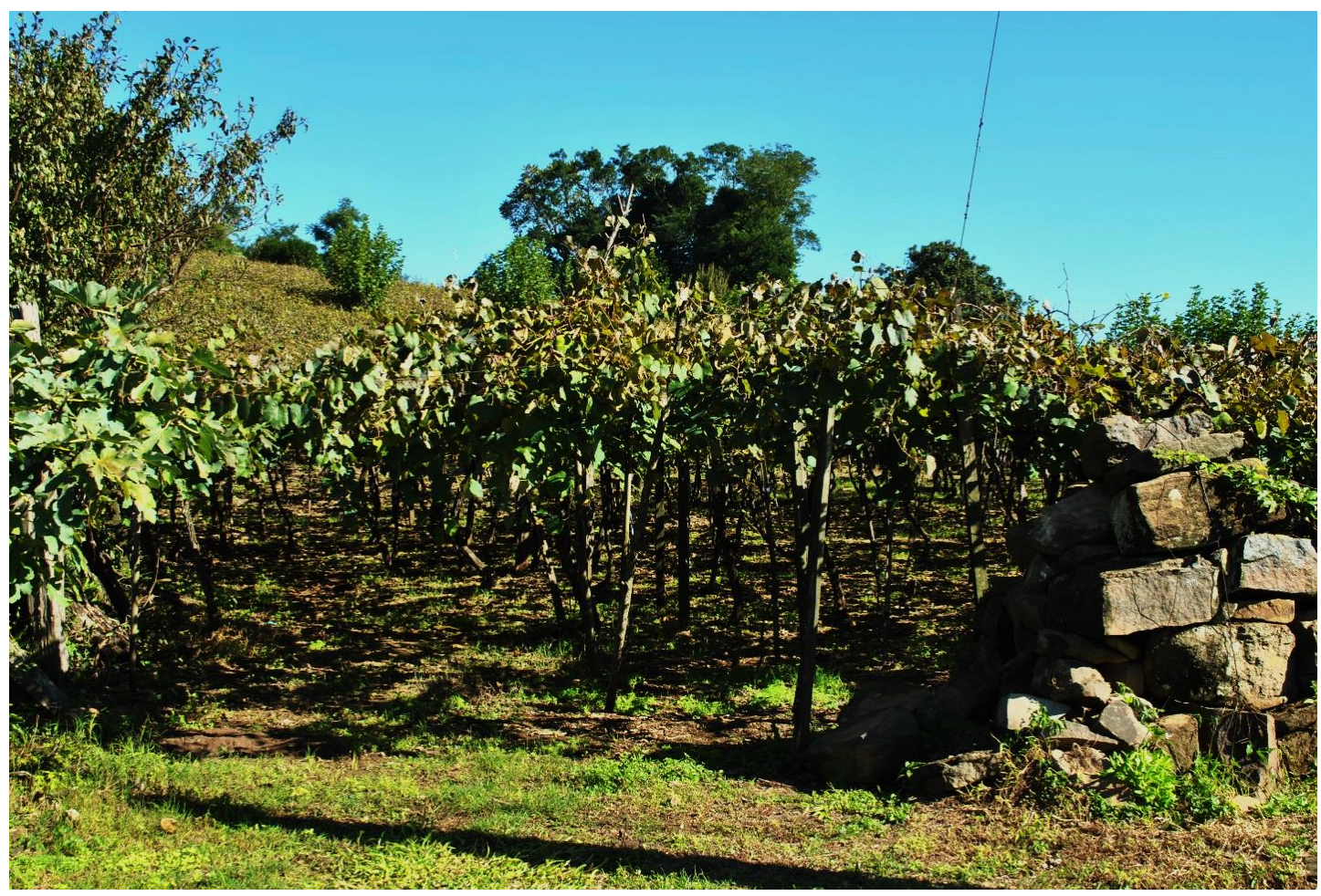

Foto 31: pilares de amarração feitos de rochas basálticas talhadas

Fonte: acervo do autor (2014)

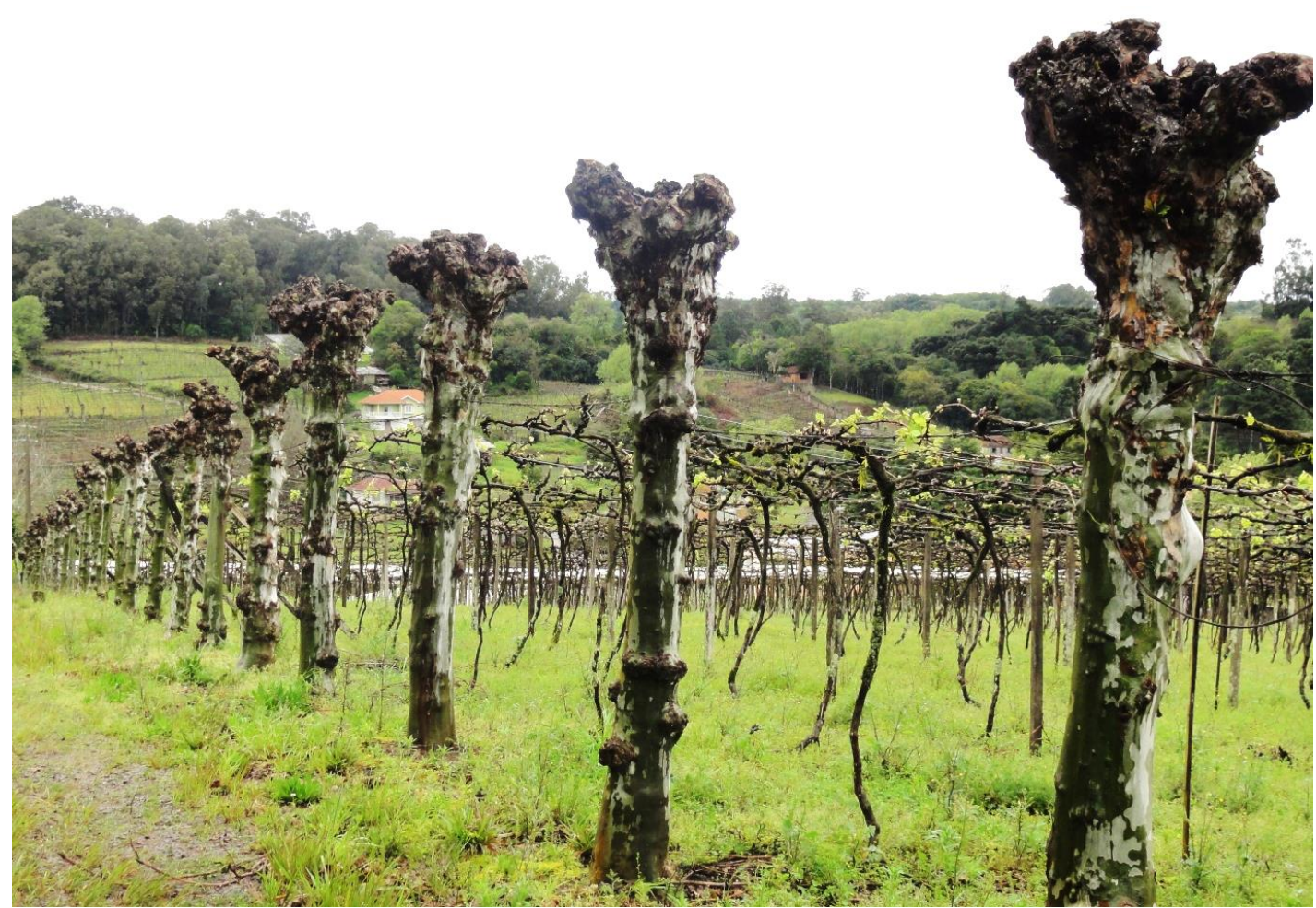

Foto 32: Plátanos sendo usados como pilares de amarração em solos rasos

Fonte: acervo do autor (2014) 


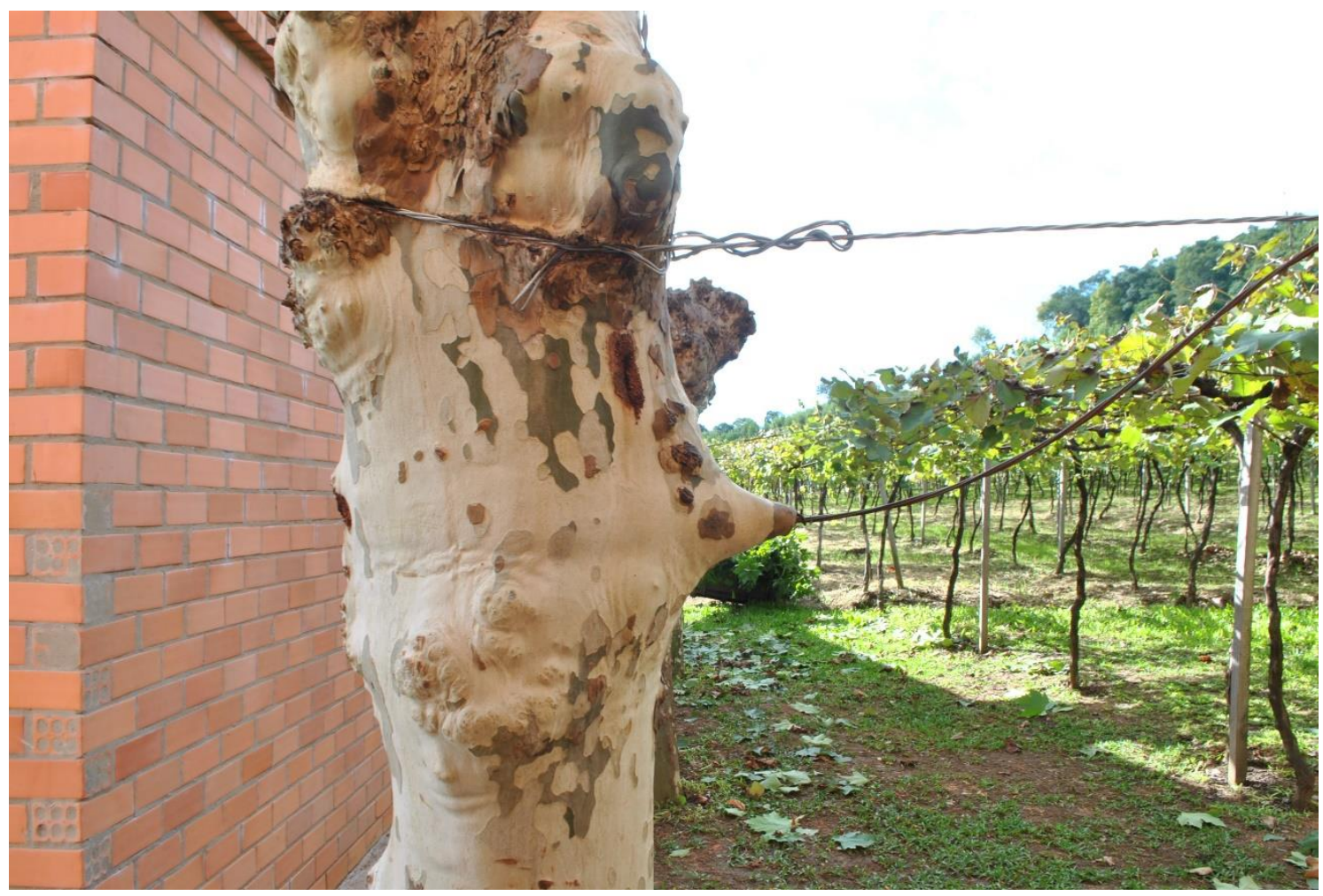

Foto 33: Plátano usado como pilar que "absorveu" o arame

Fonte: acervo do autor (2014)

Os plátanos têm função múltipla no Vale dos Vinhedos, segundo os produtores, além da contenção e sustentação dos parreirais os plátanos são podados anualmente e seus ramos podados servem tanto para adubar o solo como para alimentar os fornos de pedra. O discurso do produtores confirma a teoria da "prática de cobertura morta" do solo, onde o autor Raymond Pebayle (1973) afirma que a forma de condução dos parreirais feito pelos colonos "é muito ligada à terra" quando no inverno espalhasse sobre o solo do parreiral ramos e outras formas de cobertura vegetal, podendo ainda acrescentar "borra de uva", palhas de outras culturas e esterco para fazer o que os colonos atribuem de "engorda da terra", que segundo o autor, essa prática agrícola seria para "restituir ao solo uma parte de sua riqueza original", fato este que podemos notar na foto 34, que mostra as podas de plátanos esperando suas múltiplas destinações. 


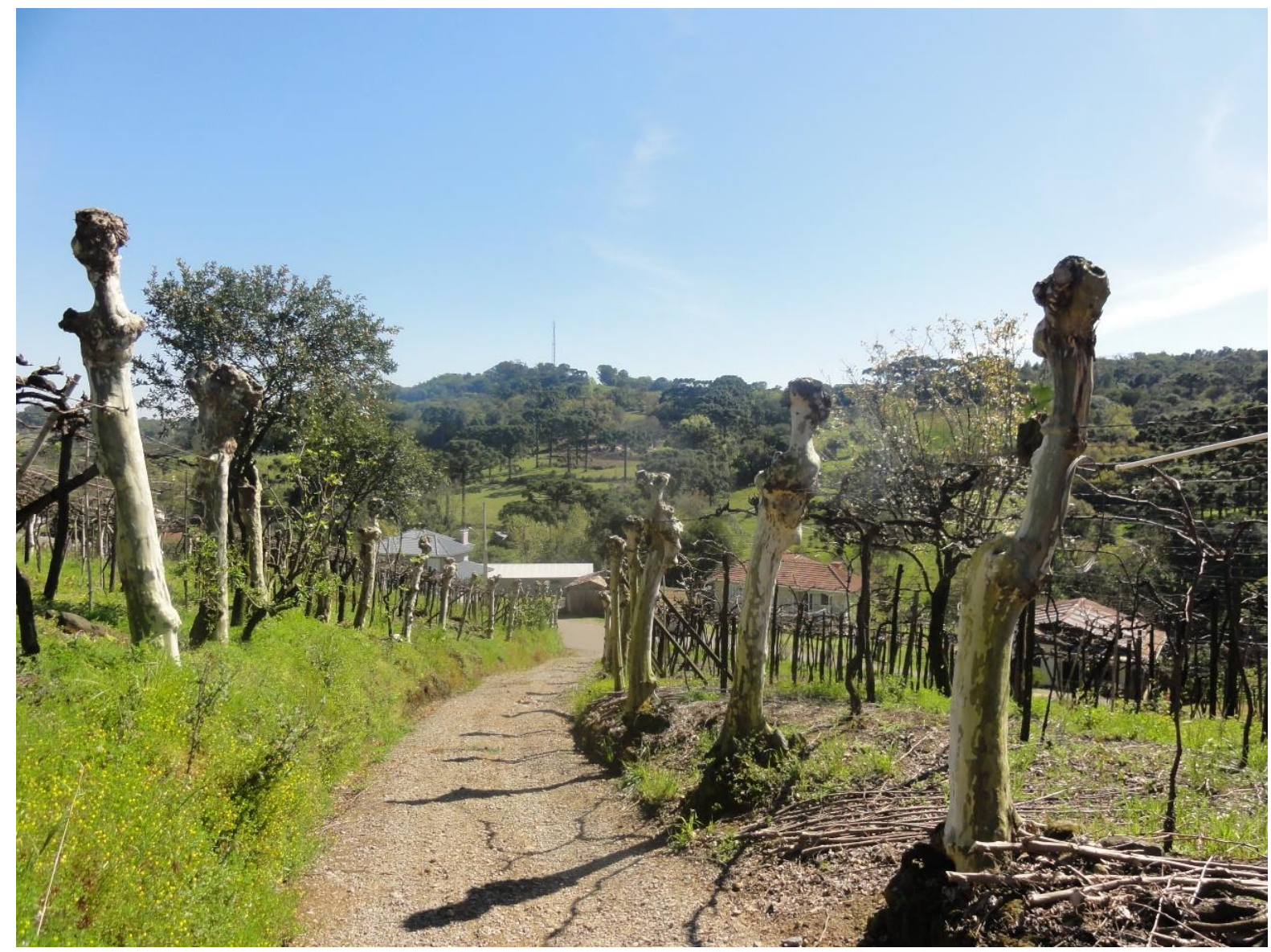

Foto 34: Plátanos podados e podas sobre o solo aguardando destinação dada pelos produtores

Fonte: acervo do autor (2014)

Ainda dentro da forma de produção colonial dos vinhos no Vale dos Vinhedos, outra planta que se mostra de grande importância na produção e condução dos vinhedos é o vime Salix sp.. Trata-se de um arbusto conhecido pelos moradores da região, mas pouco conhecido pelos enoturistas e população em geral. $\mathrm{O}$ vime é uma espécie arbustiva que produz ramos longos, finos e maleáveis em abundância. Os ramos de vime são usados para produção de artesanato, principalmente no fabrico do cesto de vime, que segundo Dalcin (2008) é uma técnica oriunda do norte da Itália e é presente em toda a colônias italiana.

No entanto, a função que o vime tem juntamente com as uvas e os plátanos na produção de vinhos vai além dos artesanatos possíveis. Na verdade, seu uso na viticultura é dotado de características artesanais. O vime é usado no campo principalmente para condução dos parreirais depois de ser submetido a um tratamento de imersão por até 12 dias em água, que deixa seus ramos ainda mais maleáveis. 
Os produtores juntam um feixe de vime e amarra na cintura, como mostra a foto 35 . Após fixado o feixe de vime à cintura o produtor inicia o "amarramento do parreiral". Como os ramos de vime tornam-se extremamente maleáveis e resistentes a tração, o agricultor amarra as brotações da videira junto ao arame e faz uma poda na ponta na ponta da brotação.

Alguns segundos após a poda, é possível ver e sentir o fenômeno que os produtores chamam de "choro da videira" como mostra a foto 36.

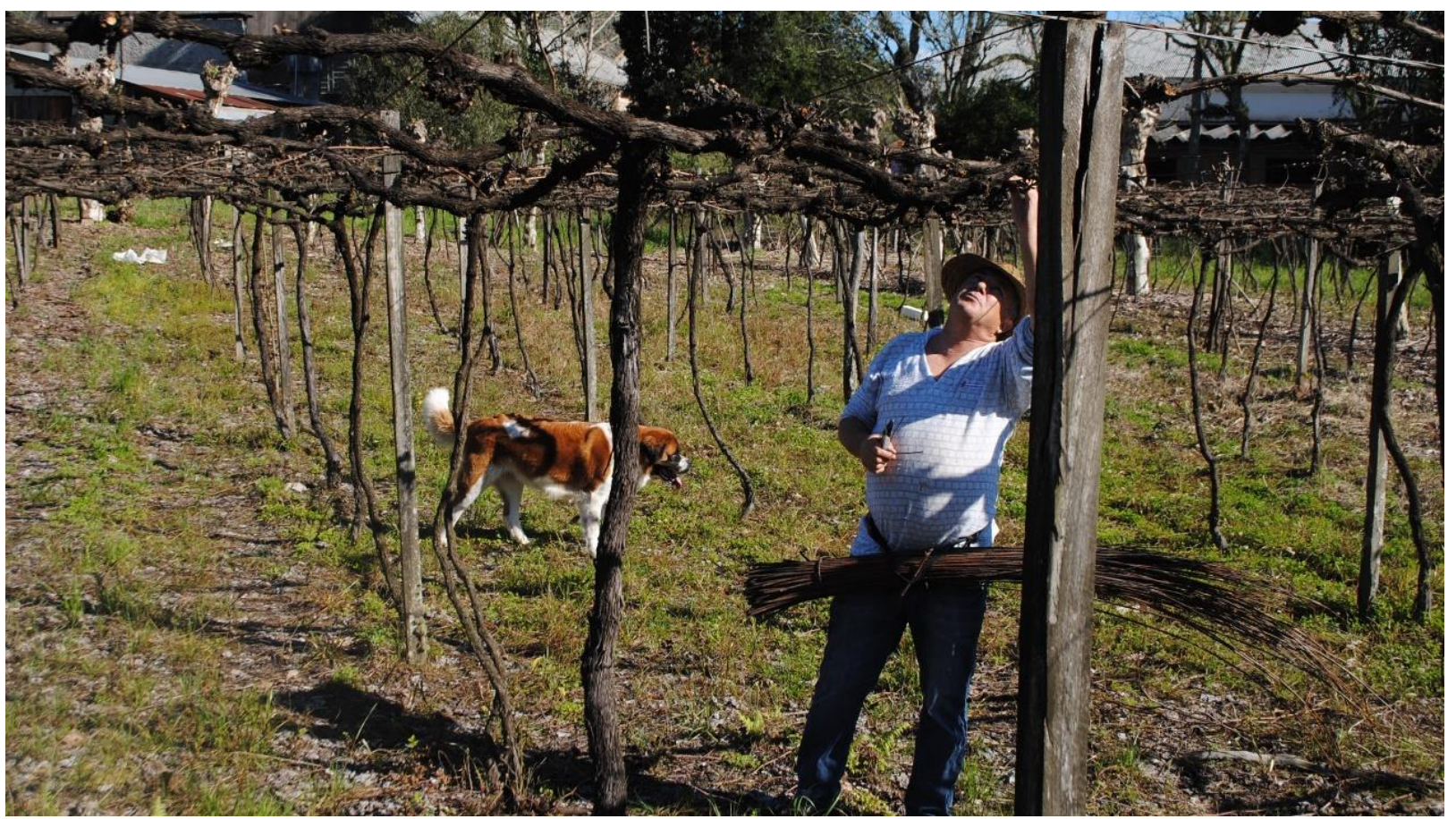

Foto 35: forma tradicional de "amarrar o parreiral" com vime

Fonte: acervo do autor (2014) 


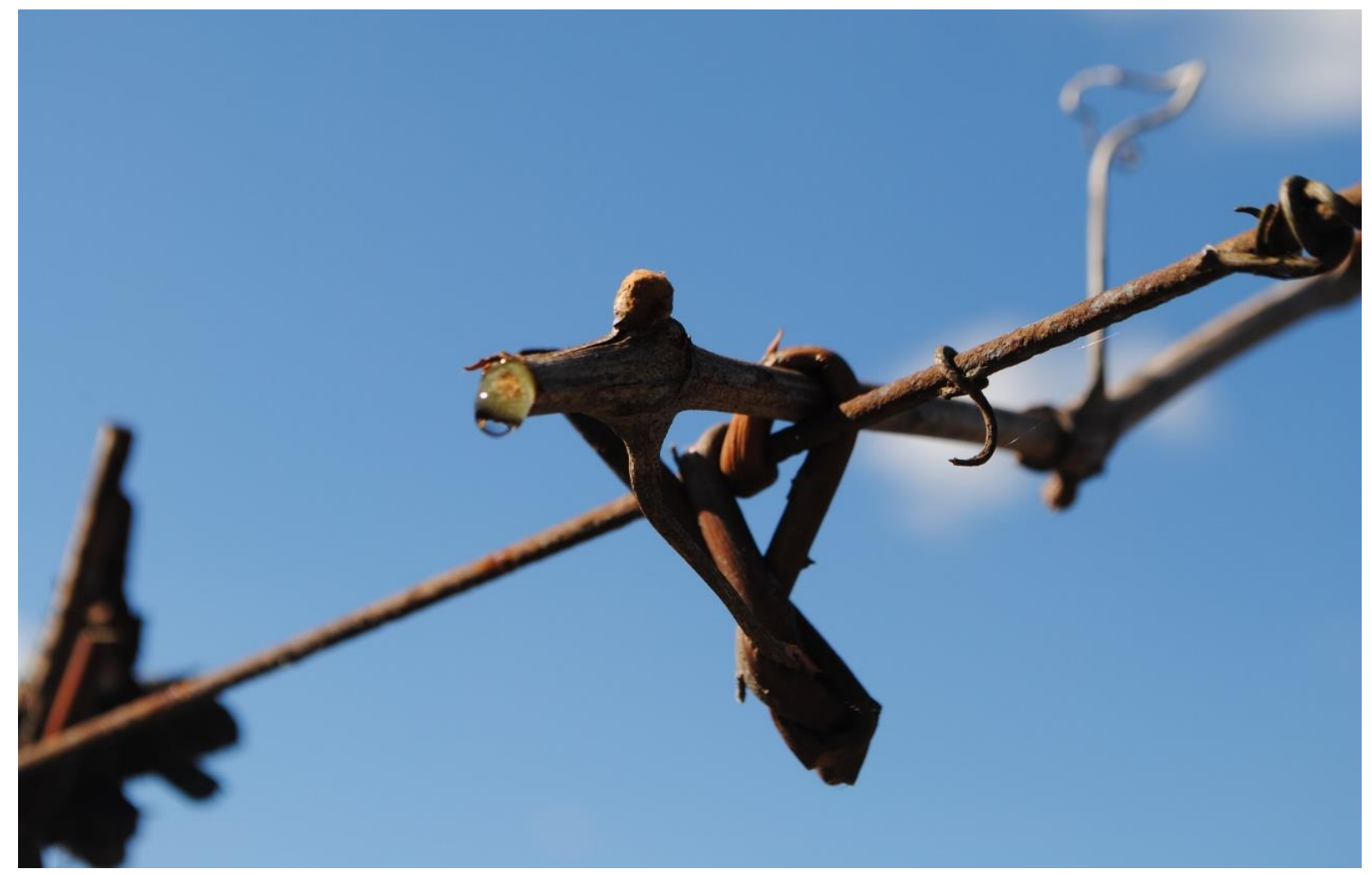

Foto 36: detalhe do "choro da videira" após ser fixada com vime e podada

Fonte: acervo do autor (2014)

Após o período das podas, amarras e condução do parreiral, vem o momento dos cuidados fitossanitários. Como é dito à moda colonial, seriam os cuidados com as doenças do parreiral. Neste ponto temos uma grande divergência entre os próprios produtores coloniais e entre os acadêmicos não é diferente. As discordâncias acadêmicas são tantas, principalmente no ramo das ciências agrárias, que por muitas vezes tendem a se tornar paradigmas, e não caberia discorrer sobre essas infinitas percepções neste trabalho.

Pode-se dizer que os cuidados fitossanitários feitos nos parreirais coloniais são feitos com cautela. Atualmente os produtores da região tem conhecimento dos perigos e malefícios dos agrotóxicos usados. Alguns usam preventivamente e outros usam somente quando a doença já está presente. É notório que, atualmente, todos os produtores tomam os devidos cuidados com a manipulação e tempo de carência do agrotóxico.

A Embrapa - Empresa Brasileira de Pesquisa Agropecuária (2003) conceitua o tempo de carência como o intervalo de tempo entre a última aplicação e a colheita. Trata-se de uma medida necessária para que o alimento colhido não possua resíduos de agrotóxicos em níveis superiores ao limite máximo permitido pelo Ministério da Saúde. Atentando ainda que a 
comercialização de produtos agrícolas contendo resíduo de agrotóxico superior ao limite máximo fixado pelo Ministério da Saúde é ilegal.

Mas nem sempre foi assim, o produtor Jandir Crestani afirma que o uso de agrotóxicos foi incentivado e algumas vezes feito de forma enganosa há alguns anos atrás. Segundo o produtor, inicialmente os agrotóxicos eram usados e aplicados sem nenhuma preocupação, lembra que em tempos anteriores aplicava simultaneamente agrotóxicos e fumava, fazia a aplicação de agrotóxicos e depois não lavava a mão antes de beber água ou de se alimentar. Algum tempo depois, houve um trabalho dos técnicos da Emater e Embrapa "contraindicando" o uso de agrotóxicos desnecessariamente. O produtor cita ainda que após esse trabalho de conscientização do uso dos agrotóxicos as empresas de agrotóxicos diziam que se tratava de "remédios agrícolas" para atenuar o termo agrotóxico.

O produtor lembra ainda, que houve duas mortes de pessoas próximas, oriundas do uso dessas substâncias. Atualmente o produtor diz que prefere não usar agrotóxicos para o controle de plantas que nascem espontaneamente em seu parreiral. Segundo ele os técnicos da Emater indicam que os produtores mantenham os solos sempre cobertos com plantas forrageiras, ou material orgânico. O produtor faz consórcio com animais para adubar o solo e manter as ervas espontâneas sob controle, como fica demonstrado na foto 37.

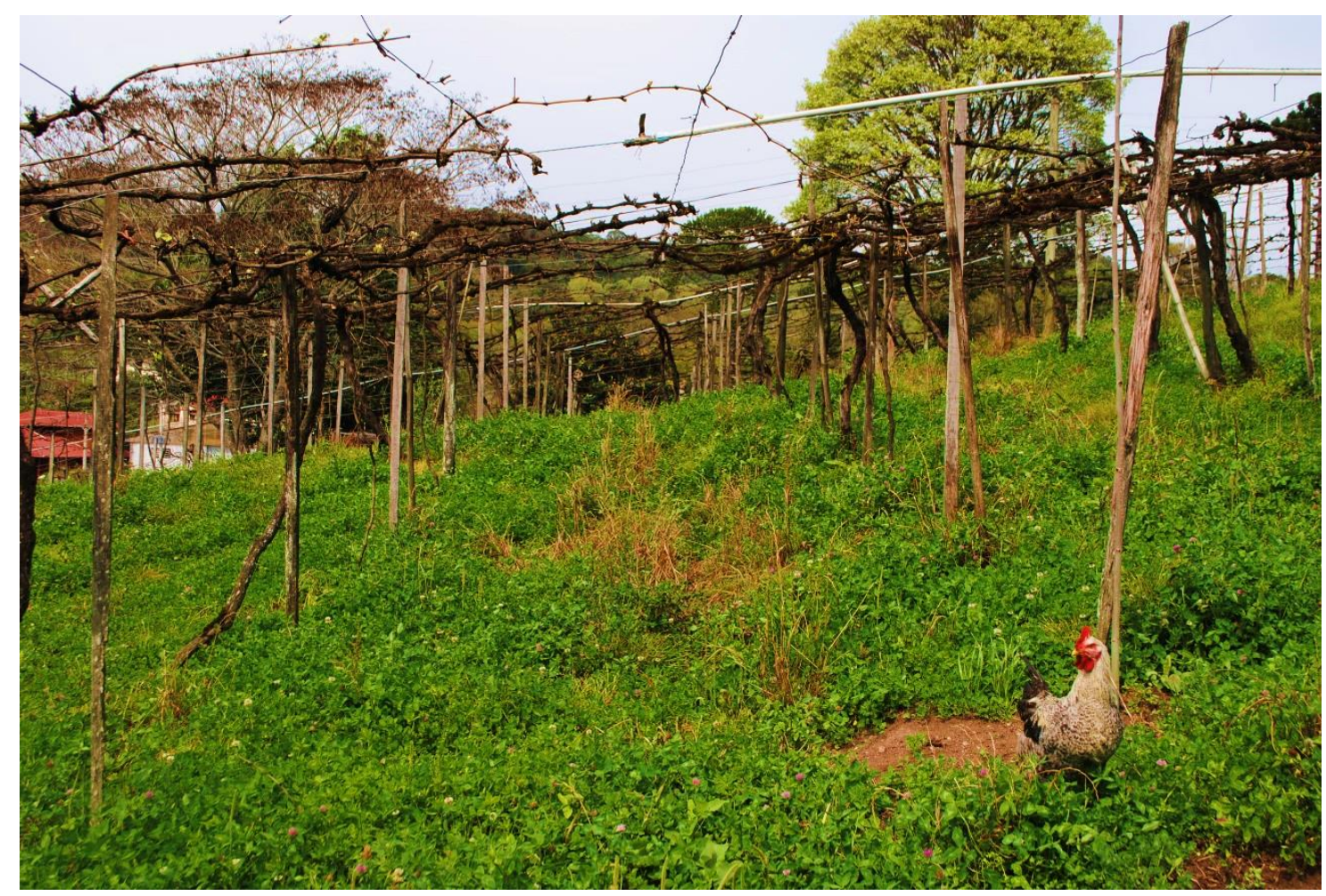

Foto 37: atualmente o produtor Jandir Crestani mantém a forração do solo no parreiral

Fonte: acervo do autor (2014) 
Da mesma forma que alguns produtores optam por não usar agrotóxicos, outros usam com parcimônia. Alguns produtores usam uma técnica bastante antiga e conhecida mundialmente na preservação dos vinhedos. Trata-se do plantio de roseiras - Rosa sp. principalmente nas pontas das linhas de produção, como mostra a foto 38 .

Segundo as explicações de vários produtores, as roseiras são atacadas primeiro que as videiras, servindo além da ornamentação do parreiral, mas também como um indicador da sanidade do parreiral. Os produtores dizem que quando algum patógeno é verificado nas roseiras, ainda é possível fazer a prevenção nos parreirais sem que eles tenham nenhum dano causado.

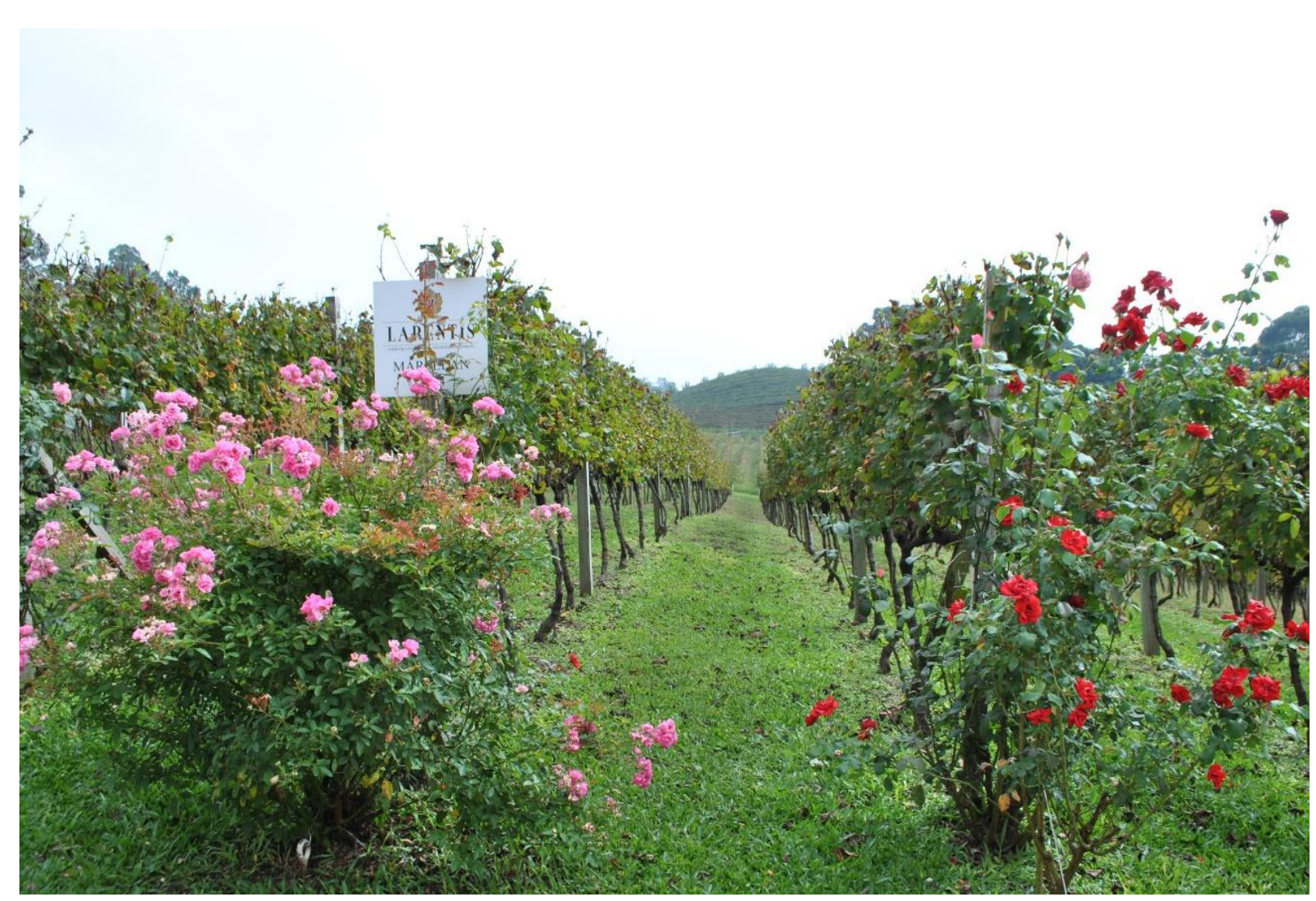

Foto 38: plantio de roseiras nos parreirais como forma de indicadores de fitopatologias

Fonte: acervo do autor (2014)

A questão do uso de agrotóxicos deve ser tratada com muita cautela, principalmente pelos produtores coloniais. Os produtores dizem que apesar de não gostarem de usar os agrotóxicos, se sentem "reféns" do uso e dos preços cobrados. O produtor Carlos Alberto cita que os custos com agrotóxicos são altíssimos e diz que sua produção é dependente do uso desses produtos, diz ainda que o motivo desses preços serem tão altos no Brasil é devido a alta taxação 
tributária pois os mesmos produtos vendidos no Uruguai é vendido por aproximadamente metade do preço comercializado no Brasil. O produtor relata que já foi algumas vezes ao Uruguai para comprar esses produtos, no entanto foi apreendido por comprar 20 litros de agrotóxico e foi obrigado a pagar uma multa de $\mathrm{R} \$ 26.000,00$.

O produtor diz que da forma como as leis são feitas obriga os produtores, "que são pessoas boas" à permanecerem fora da lei, como é o caso da compra de insumos agrícolas em outros países e a comercialização dos vinhos coloniais.

A aplicação dos agrotóxicos na região pode ser feita de várias formas, as duas formas mais usuais são por meio de bombas costais (Figura 05) ou de forma mecanizada (Foto 39). A aplicação com bombas costais é mais usada para pequenas áreas, tem a vantagem de poder ser feita uma aplicação mais localizada, gerando menor consumo dos produtos, no entanto é uma forma de aplicação que aumenta as chances de intoxicação do aplicador por aplicar os produtos na sua frente, já a aplicação mecanizada é feita de maneira generalizada em áreas maiores, tem a vantagens de manter o aplicador mais distante dos produtos que são pulverizados na parte de trás do maquinário, no entanto tem a desvantagem de tender a se perder parte da aplicação pela deriva do vento, como pode ser visto na foto 40, onde mostra a nuvem de agrotóxico que é facilmente levado pelo vento. Quando a foto 40 foi tirada era notório o cheiro de agrotóxico que o vento trazia do parreiral, caracterizando assim um problema deste modo de aplicação em regiões onde existem outras culturas, pessoas e outros animais próximos.

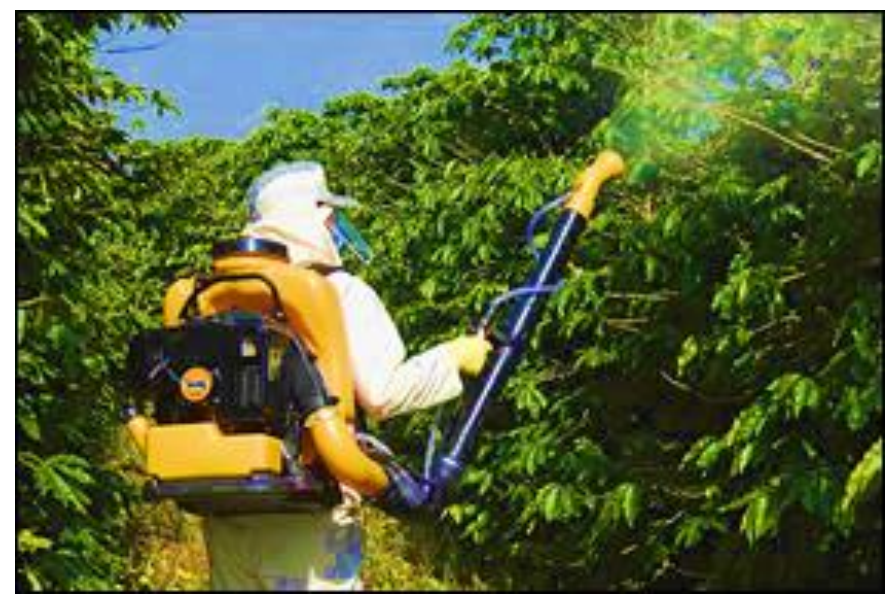

Figura 05: aplicação feita com bomba costal

Fonte: Portal Guaranyind.com.br 


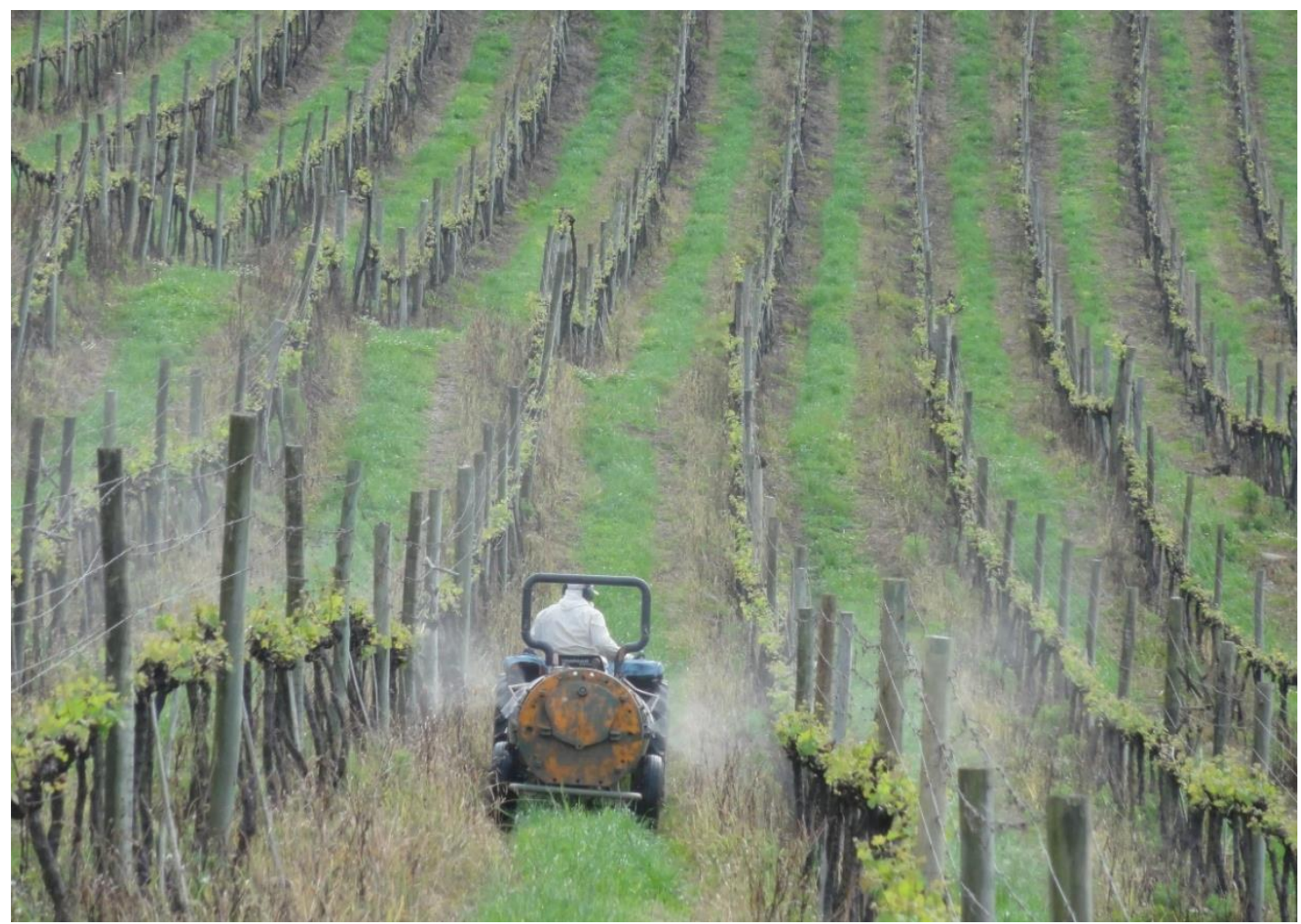

Foto 39: Aplicação mecanizada de agrotóxicos nos vinhedos

Fonte: acervo do autor (2014)

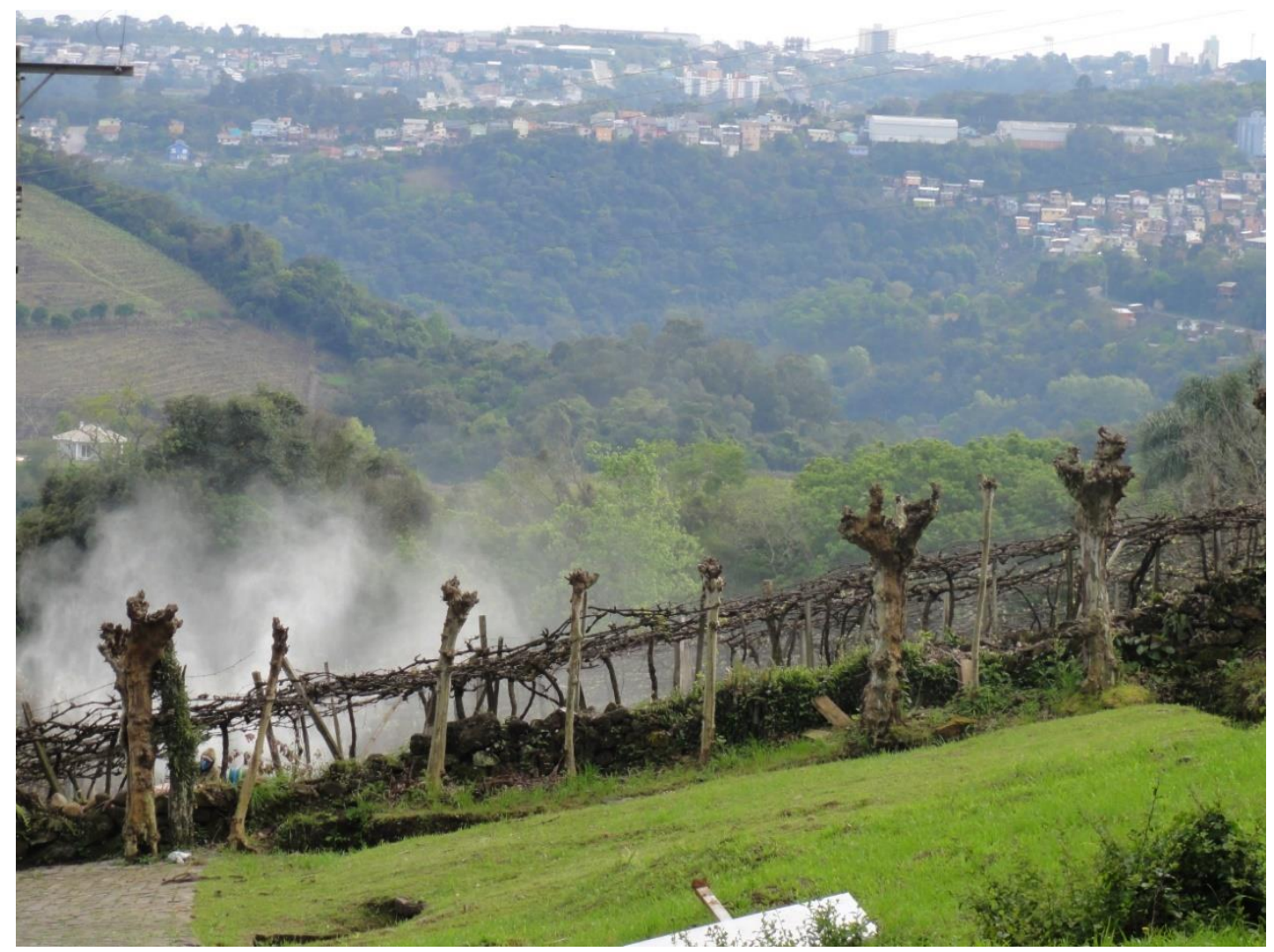

Foto 40: nuvem de agrotóxico à deriva do vento no Vale dos Vinhedos

Fonte: acervo do autor (2014) 
Outra forma bastante diversa na produção dos vinhos coloniais é forma de acomodação dos vinhos ou crianza como dizem em dialeto italiano. Alguns produtores acomodam seus vinhos em barris de madeira, como é caracterizado de maneira mais tradicional.

Muitos produtores mantém seus barris de madeira na propriedade mesmo que já tenham comprado outros recipientes de outros materiais.

É interessante notar que a cultura é de fato mutável, citando o feito do produtor Maikon Panizzi que optou por permanecer com os barris de madeira tradicionais, mas gostaria de inovar na apresentação dos barris. Desta forma, pintou os barris com tinta branca a base de água com corante vermelho, no entanto não obteve a coloração que almejava inicialmente (Foto 41), como cita o vitivinicultor. Quando questionado se tem vontade de mudar a cor dos barris, ele afirma que não era essa cor que pensou inicialmente, mas agora que está feito vai deixar. Como o produtor diz "é bom que fica diferente de todas as vinícolas"

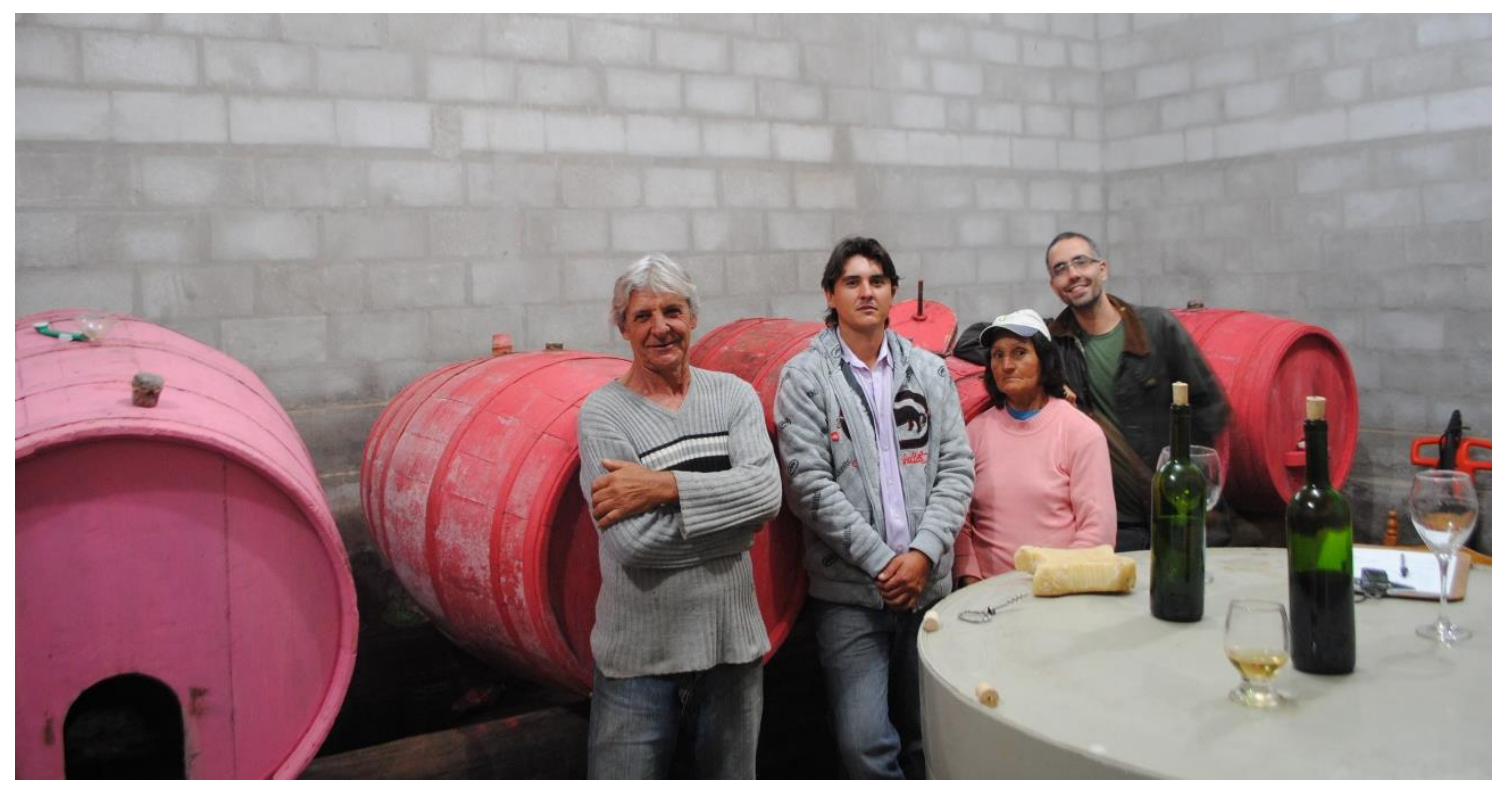

Foto 41: Tradição e modernidade nos barris (Produtor Maikon Panizzi entre seus pais e o enoturista-pesquisador). Fonte: acervo do autor (2014)

Alguns produtores investiram em equipamentos mais novos como mostra a foto 42 , onde o produtor Vitório Somensi trabalha com recipientes de plástico. Segundo o produtor, os barris de plástico são bons pois não dão cheiro nem gosto ao vinho ou suco, além de ser muito mais fácil de limpar e fazer os procedimentos enológicos. 


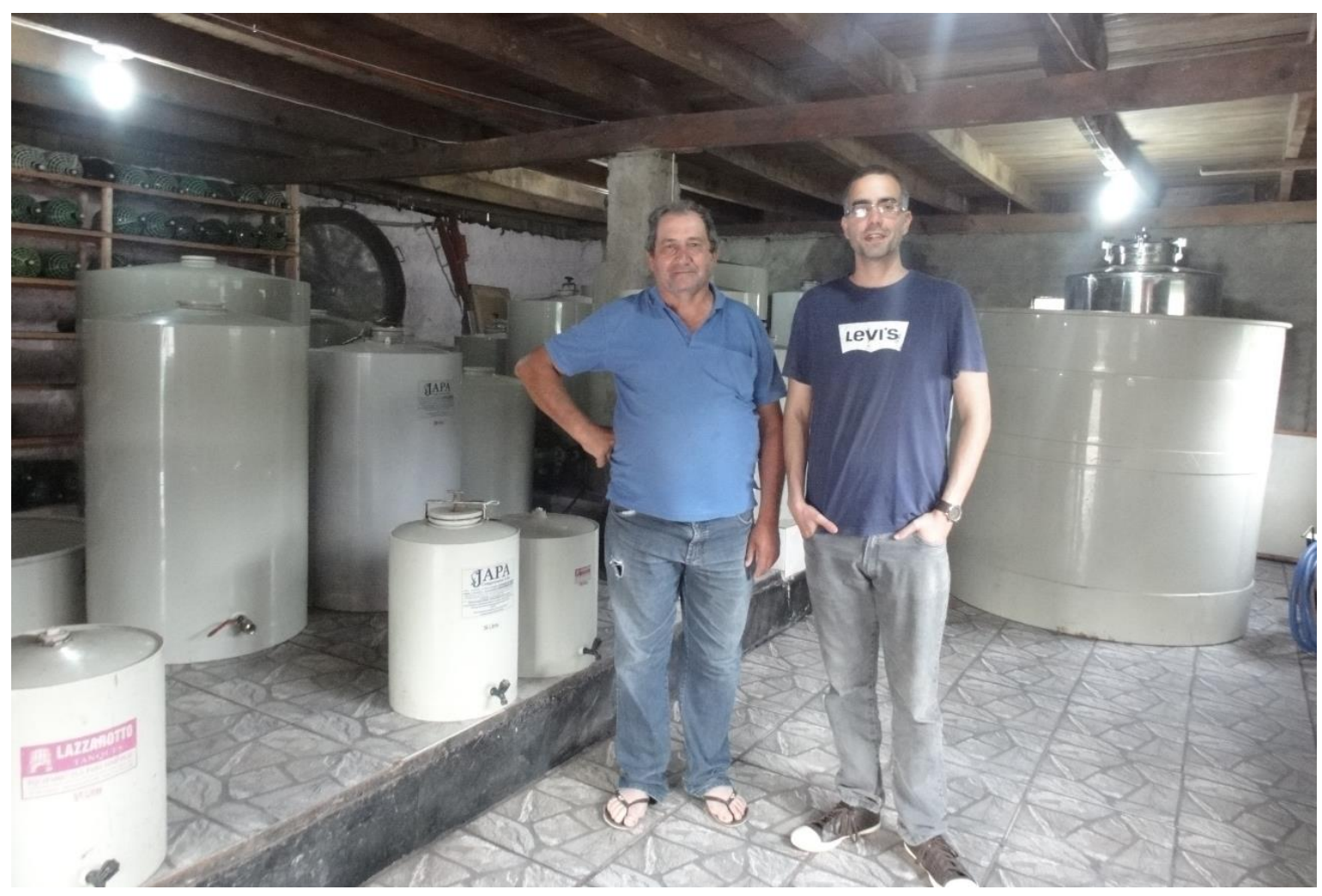

Foto 42: produtor Vitório Somensi e seus novos barris de plástico

Fonte: acervo do autor (2014)

No entanto, outros produtores coloniais optam por investir mais e adquirir pipas de inox. Como é o caso do senhor Todeschini (Foto 43), que já teve uma produção consideravelmente alta e dos irmãos Batisttello (Foto 44) que dizem estar investindo em pipas de inox e outros equipamentos pois pretendem formalizar a produção.

Os Irmãos Batisttello dizem que as pipas de inox tem soldas especiais que fazem uma grande diferença na higienização das pipas. As pipas de inox são as mais recomendadas enologicamente, pois é o material que permite um maior controle das variações de temperatura, diminui significantemente a contaminação e não passa gosto nem cheiro para os vinhos e sucos. 


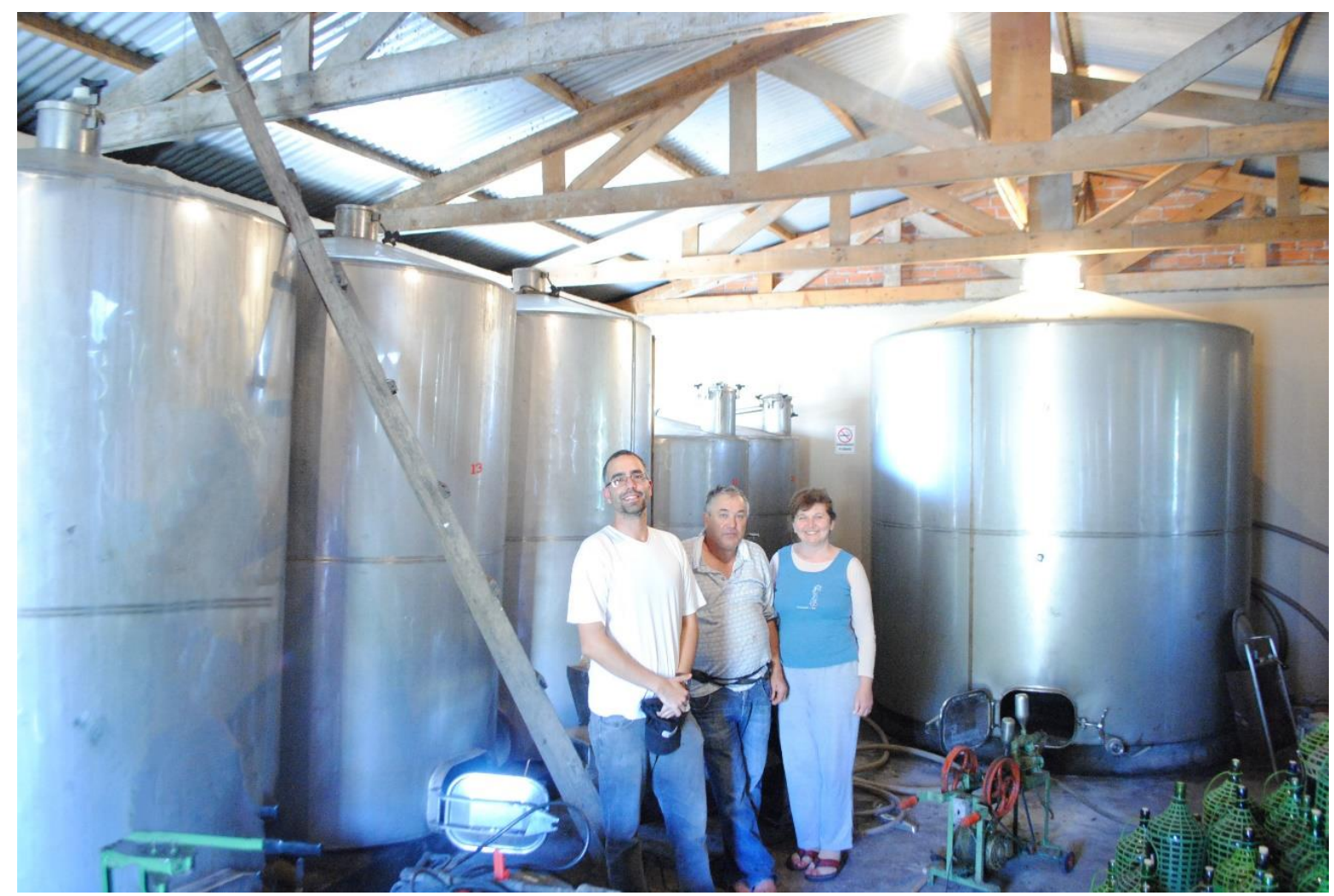

Foto 43: Enoturista-pesquisador e o casal Rui e Aide Todeschini com suas pipas de inox

Fonte: acervo do autor (2014)

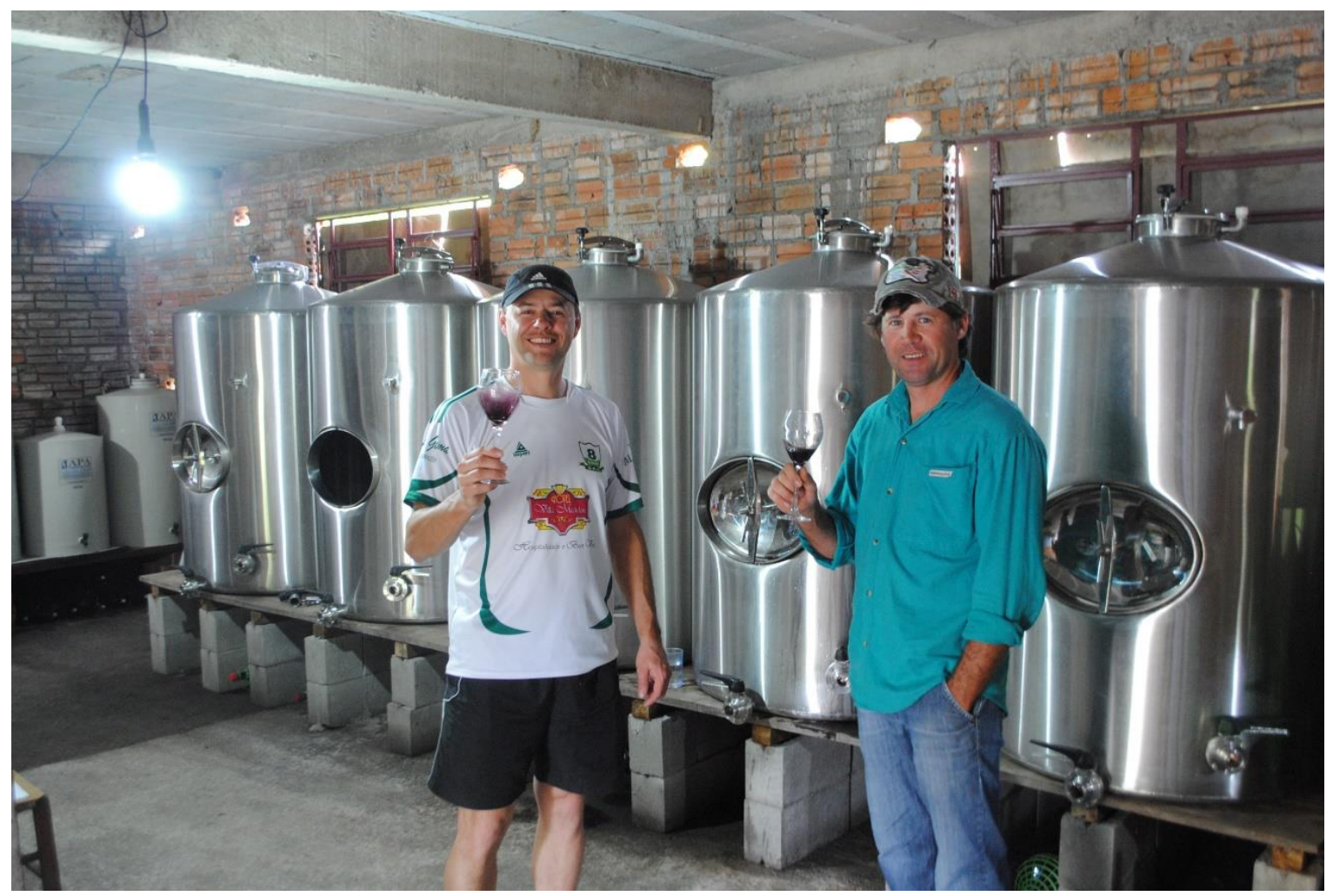

Foto 44: Mateus e Marcelo Batisttello exibindo seus vinhos recém tirados das pipas de inox

Fonte: acervo do autor (2014) 
Foi observado que o procedimento de lavagem dos barris é uma tarefa muito trabalhosa e que deve ser feita com muito cuidado. Tanto nas produções coloniais como nas grandes vinícolas industriais, existe uma grande atenção na hora da lavagem dos barris, pois trata-se de uma tarefa que se mal planejada e mal executada pode causar morte do operador (Foto 45). Por ser caracterizada como um trabalho em ambiente confinado devem-se tomar todas as medidas de segurança estipuladas na Norma Regulamentadora $n^{\circ} 33$, exigindo o acompanhamento de um Engenheiro de Segurança do Trabalho, isto é, nas vinícolas que já estão produzindo legalmente. Já nas vinícolas de produção informal, a lavagem é feita da mesma maneira como é feita a produção, informalmente, mas segundo os produtores, não há histórico de ocorrência de acidentes na região.

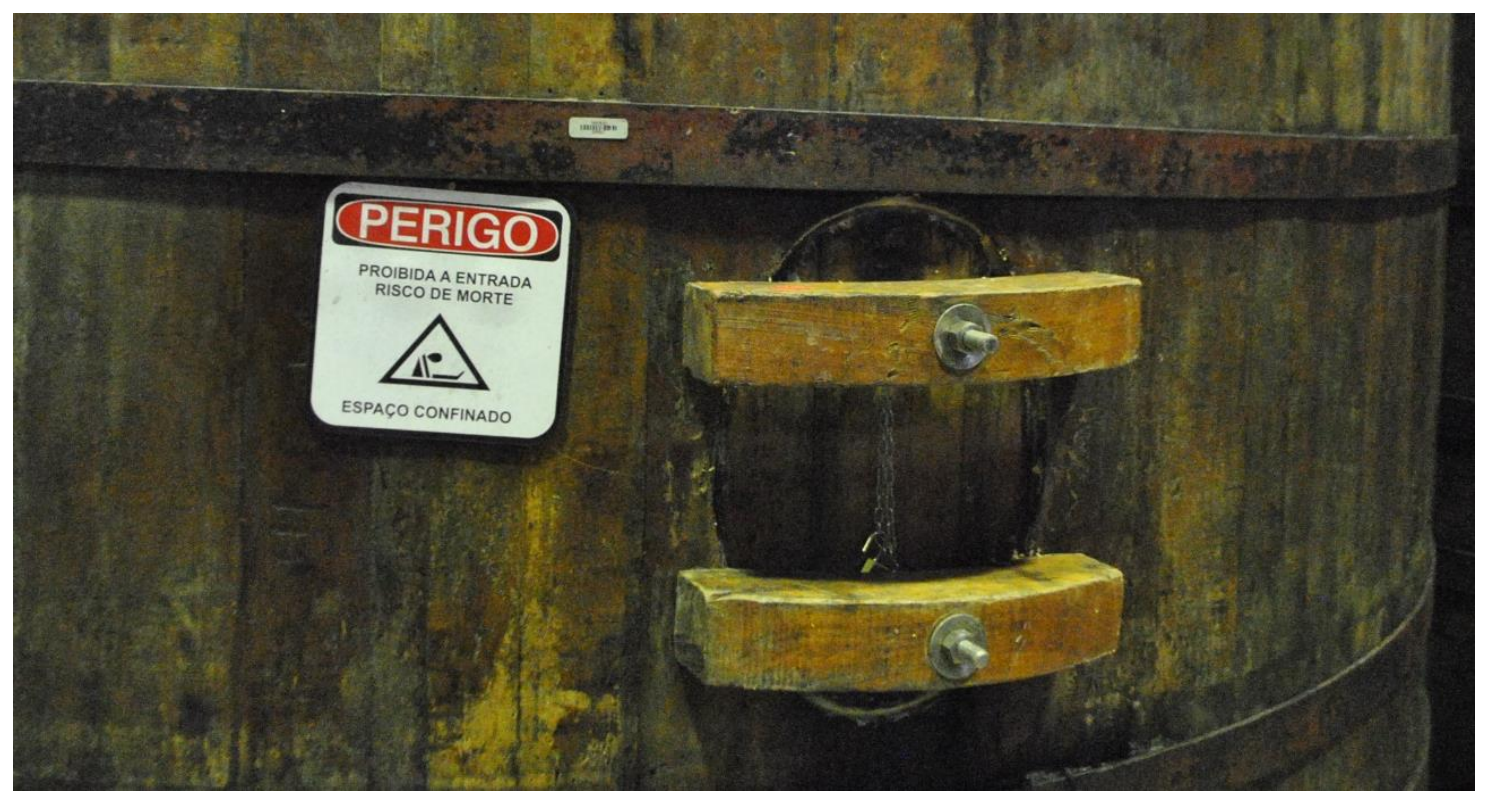

Foto 45: placa de notificação da vinícola Miolo. PERIGO: Proibida a entrada. Risco de Morte. ESPAÇO CONFINADO. Fonte: acervo do autor (2014)

Mesmo sabendo que a produção de vinho colonial não segue os mesmos ritos e procedimentos que as indústrias vinícolas, quando questionados sobre a possibilidade de riscos à saúde, todos os produtores coloniais consultados são unanimes e enfáticos ao dizer que o vinho colonial não coloca em risco a saúde de quem bebe. A esposa de um dos produtores diz que atesta que o vinho colonial não faz mal à saúde, pois os produtores são os principais consumidores, e certamente não iriam produzir nem consumir algo que fizesse mal para a própria família.

A Senhora explica que os produtores são os que consomem a maior parte do vinho produzido, estimando que em sua casa mais de 1.000 litros de vinho colonial sejam consumidos 
por ano. Segundo ela, o produtor toma todos os cuidados necessários para a produção do vinho, pois "em primeiro lugar vem o consumo próprio e da família e depois o vinho para vender."

A afirmação da produtora é reforçada por todos os produtores, até mesmo por aqueles que não tem o hábito de beber vinho frequentemente. Muitos produtores enfatizam que o vinho colonial não faze mal à saúde de quem bebe, dizem até que o vinho colonial é mais saudável que os vinhos das grandes cantinas.

\subsection{O TRABALHO DO COLONO COMO FORMA DE RESISTÊNCIA}

Inicialmente devemos lembrar que a perspectiva do trabalho árduo na própria terra para os imigrantes italianos não era vista como algo negativo ou penoso, mas sim como a realização de um sonho distante e que só foi possível de ser realizado em outro continente. Foi exatamente a possibilidade de trabalhar de sol a sol em sua própria terra que impulsionou tantas famílias italianas a saírem do continente europeu e se lançarem em navios lotados de italianos guiados pela mesma pulsão. Esse é somente um dos motivos que explica a ligação que o colono tem com o trabalho agrícola.

No entanto esses imigrantes trouxeram muito mais que roupas, ferramentas e suas malas. Trouxeram suas raízes, sua cultura, seus hábitos alimentares e modo de trabalho. É sabido que os imigrantes italianos eram dotados de um senso de coletividade bastante representativo, que foi se atenuando com o passar dos anos e gerações. No entanto, o senso de coletividade ainda pode ser visto em seus hábitos de trabalho e congregações.

O trabalho na terra é a principal forma de sustento dos produtores, que assim o fazem desde os tempos antigos dos imigrantes. Como é bastante dito entre os colonos da atualidade: "O Brasil precisava de braços para a agricultura" e é isso que os motiva a continuar na produção agrícola. Trabalhar com a agricultura e criação de animais é inerente a sobrevivência desses produtores.

O produtor José Milani diz que é por meio do seu trabalho na propriedade que ele viabiliza a fartura e diversidade de alimentação da sua família. O produtor cita que não teria condição de comprar carne para a alimentação cotidiana se dependesse somente da compra da carne em mercados. O colono diz que o modo de produção de alimentos coloniais é muito mais antigo que a forma como a indústria de alimentos faz hoje. O produtor afirma não ter dúvida que os alimentos coloniais são mais saudáveis que os alimentos industrializados. A produção 
de alimentos coloniais ocorre de forma bastante natural e despretensiosa, exatamente da mesma forma com que as passadas gerações faziam. Como é de costume, faz-se o pão colonial no forno à lenha, do leite é possível fazer o queijo, a coalhada e requeijão, da uva é possível fazer consumo do vinho e da geleia e das suas criações de animais é possível fazer o consumo diário de carnes, ovos, salsichas, salames, copas e mais uma infinidade de alimentos sob vários tipos de tratamentos.

A comercialização de produtos coloniais ocorre para o produtor José Milani de uma forma bastante natural, ele diz que normalmente vende uvas de mesa e usa o talão do produtor rural (Foto 46), no entanto quando o consumidor se depara com algumas garrafas de vinho colonial, um pão colonial ou alguns defumados, ele pergunta se estão à venda, e é assim que são vendidos os produtos coloniais. O produtor atenta ainda que algumas pessoas chegam a bater na sua porta ou o abordá-lo no campo pedindo por informação sobre onde seria possível comprar determinados produtos coloniais.

Todos os produtores dizem que da forma que a lei foi aprovada, com os vetos na possibilidade de vender os vinhos coloniais através do talão do produtor rural, eles simplesmente vão continuar a produzir e comercializar na mesma forma que sempre fizeram, ou seja, da mesma forma que era feito por seus antepassados. É notório que comercialização informal de vinhos coloniais é incômoda, mas não é o suficiente para imobilizar ou desarticular os produtores.

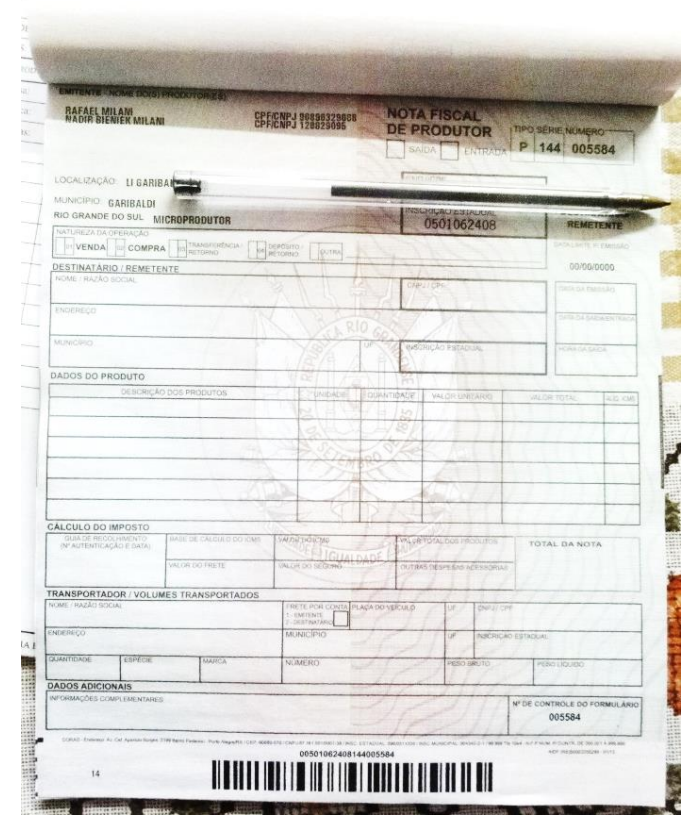

Foto 46: Talão do Produtor Rural

Fonte: acervo do autor (2014) 
Todos os produtores visitados dizem que vão continuar vendendo seus produtos informalmente, pois, segundo eles, é preferível correr o risco de uma punição que parar a produção. No entanto, não se sentem à vontade em colocar anúncios em frente às propriedades, pois acreditam que seria chamar muito a atenção da fiscalização. $O$ único produtor que colocou placa indicando o comércio de vinhos coloniais foi o produtor Roque Lazzarotto, como mostra a figura 47.

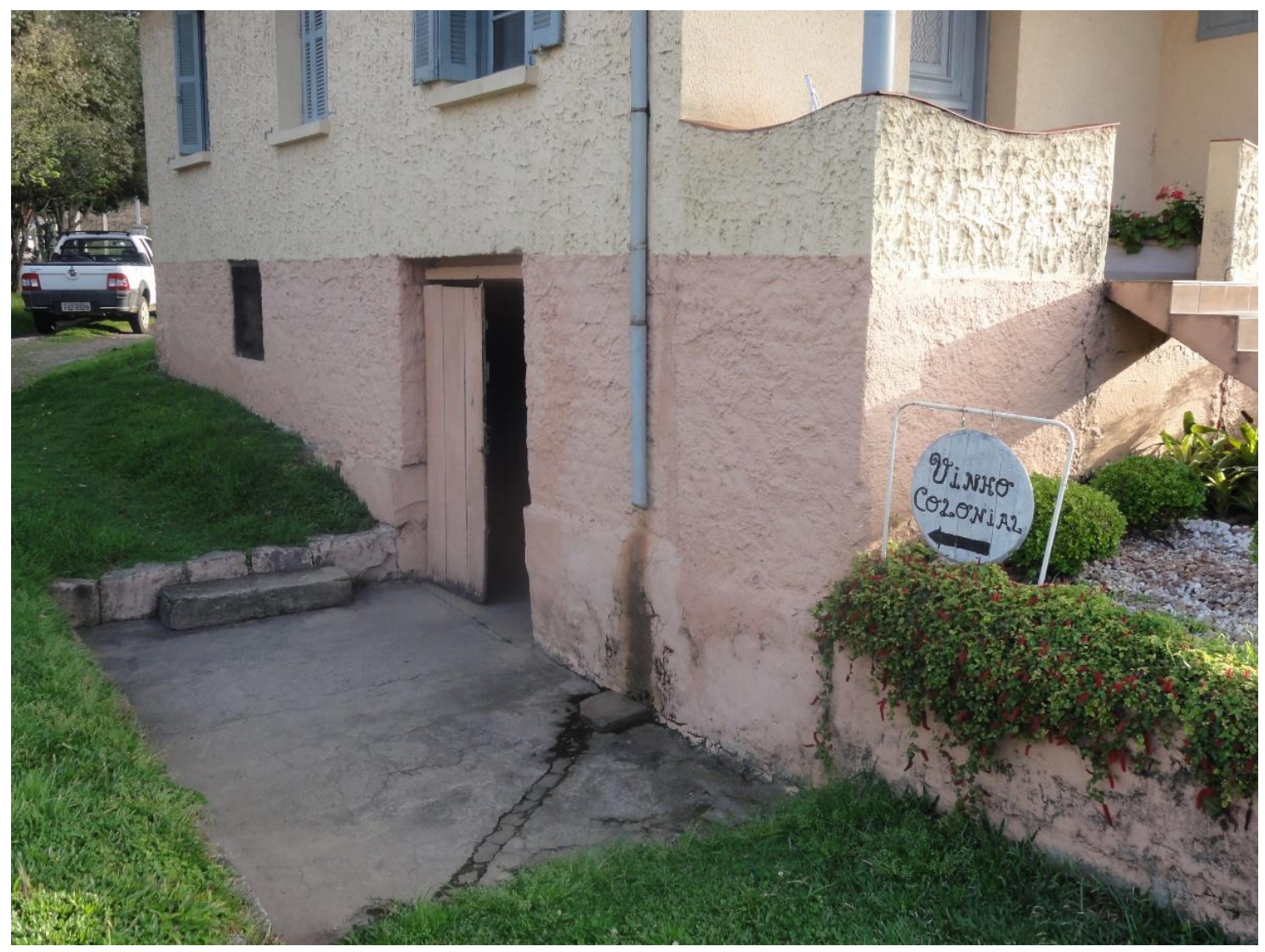

Foto 47: discreta placa indicando o comércio de vinho colonial

Fonte: acervo do autor (2014)

Em conversa com o produtor José Milani ele citou o caso de cidade mineira onde foi feita uma lei que proibia as pessoas no perímetro urbano de criar galinhas. Segundo ele, houve uma insatisfação generalizada daquela população que se uniu e foi fazer protesto até os legisladores vetarem essa lei. Quando questionado se ocorresse algo parecido qual seria sua reação, ele foi bem enfático e disse que iria fazer a mesma coisa que a população mineira fez. Segundo ele, as leis não podem ser feitas sem conhecimento de causa e efeito da realidade.

É possível pensar que a forma de produção de alimentos coloniais é, de certa forma, um tipo de produção regido aos moldes de produção do período pré-revolução industrial, uma vez 
que tem pouca ou nenhuma interferência das indústrias, utiliza a força de trabalho do trabalhador para o trabalhador e a troca ou comercialização desses produtos é feita sem a intervenção direta do Estado e, como consequência, não há a arrecadação de impostos sobre essas mercadorias. É interessante pensar que mesmo produzindo os vinhos coloniais ou outros alimentos coloniais, o produtor rompe, pelo menos em parte, com a dinâmica da exploração do trabalho do agricultor pela indústria.

Os produtores se comportam de forma dúbia com relação ao trabalho para a indústria. Além de receberem um preço abaixo do estipulado pela CONAB - Companhia Nacional de Abastecimento, um outro fator que desmotiva os viticultores é o tempo que as indústrias demoram para pagar os agricultores. Segundo os produtores consultados, o tempo em média é de 8 meses, no entanto, alguns afirmam ter recebido com um ano de atraso.

Mesmo com essas condições adversas os viticultores continuam "entregando" uvas para as indústrias vinícolas, pois é a principal forma de se capitalizarem. No entanto, não “entregam" toda a produção, alguns produtores separam uma parte da propriedade exclusivamente para a produção de vinhos coloniais, onde plantam variedades de uvas que mais agradam o seu gosto, primando pela qualidade ao invés da quantidade.

Todos os produtores de vinho colonial visitados são convictos que o beneficiamento e comercialização de vinho é muito mais interessante que a venda das uvas para as indústrias. $\mathrm{O}$ lado subversivo da produção de vinhos coloniais se dá a partir do momento em que os produtores usam parte do capital recebido das indústrias para produzir e beneficiar seus vinhos. De certa forma, podemos notar que a produção e comercialização do vinho colonial é uma forma de emancipação e autonomia dos viticultores frente à indústria.

É interessante pensar como ocorre essa relação de empoderamento dos agricultores frente ao Estado e a indústria. Se por um lado o agricultor tem seu trabalho subvalorizado pela indústria, a indústria repassa parte do seu lucro sobre o trabalho do agricultor para o Estado na forma de impostos. A partir do momento que o vitivinicultor colonial começa a vender seus vinhos coloniais para o consumidor final, cria-se um novo fluxo de capital que não passa nem pela indústria nem pelo Estado diretamente, gerando assim a capitalização, e consequentemente o fortalecimento dos produtores, uma vez que nessa transação não foi alimentada a dinâmica onde a indústria explora o produtor e o Estado fatura da indústria.

A partir da constatação anterior, é possível remeter à frase de Henry David Thoreau do seu livro sobre desobediência civil onde afirma que " a grande maioria dos homens serve ao 
Estado desse modo, não como homens, mas como máquinas, com seus próprios corpos”. (THOREAU, 1997). Sendo assim exposto, é compreensível que nem a indústria, tampouco o Estado tenha interesse nesse tipo de produção, uma vez que só os produtores de vinhos coloniais são empoderados nessa relação.

\subsection{A LEI DOS VINHOS COLONIAIS, O ENOTURISMO E O VALE DOS VINHEDOS SOB A ÓTICA DOS PRODUTORES COLONIAIS}

Uma das possíveis formas de avaliar a efetividade de uma lei é buscar saber qual avaliação que os principais envolvidos fazem sobre ela. Segundo essa forma de avaliação sobre a lei dos vinhos coloniais, foi observado que a lei dos vinhos coloniais teve uma baixa eficiência, pois notou-se uma aceitação nula por parte dos produtores da região do Vale dos Vinhedos.

Em todas as visitas realizadas, foi unânime entre os produtores a opinião de que a lei dos vinhos coloniais é desinteressante e inviável da forma como foi aprovada. Segundo o produtor José Milani, a lei dos vinhos coloniais, da forma como foi aprovada, "foi um verdadeiro balde de água fria”.

Alguns produtores, de maneira bastante humilde, apontaram possíveis melhorias e falhas na formulação e aprovação da lei. O produtor Décio Tasca comercializa formalmente sucos e geleias com rótulos e produtos registrados no Ministério de Agricultura, Pecuária e Abastecimento (Figura 06). Segundo o produtor, a grande desaprovação da lei foi devido a questões tributárias. Citando ainda que foi a questão tributária que fez com que ele optasse por suspender a produção de vinhos para o comércio.

O produtor explica que o fato do vinho ser considerado uma bebida alcoólica, impede que o comerciante seja adequando ao sistema de tributação simples. Décio enfatiza e concorda que para haver desenvolvimento deve haver a cobrança de impostos, mas que da forma que o vinho é taxado torna-o muito oneroso em relação a outras bebidas e vinhos de outros países. 


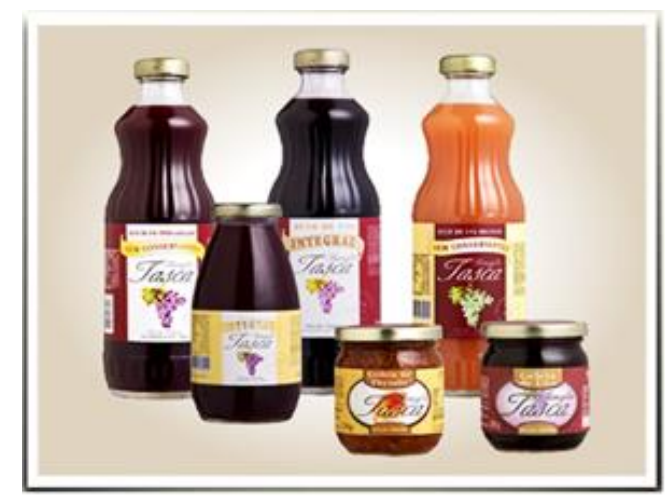

Figura 06: produtos comercializados formalmente pela Famiglia Tasca

Fonte: Portal Guia Mais.com.br

O agricultor Roque Lazzarotto cita que as leis são muito restritivas, pois são feitas de forma que abranjam tanto o pequeno quanto o grande produtor, mas atenta que a dinâmica produtiva de uma é completamente diferente da outra. O produtor afirma que em geral os produtos coloniais são mais saborosos e mais saudáveis que os produtos industrializados. Ele explica que o que faz o produto ficar bom é a maneira como o produtor trabalha, os tratos dos animais e dos tratos culturais.

O produtor se mostrou crítico com as imposições do governo quanto às proibições aos produtos coloniais. Ele afirma que parece ser contraditório o tema do atual governo ser que "Um país rico é país sem miséria", ter políticas contra a fome e ao mesmo tempo ter leis que proíbam a produção e comercialização de alimentos e bebidas coloniais. O vitivinicultor lamenta o fato dos vinhos coloniais não poderem ser enquadrados pelo sistema de imposto Simples.

O produtor Rogério Valduga é o proprietário da menor vinícola do Vale dos Vinhedos, com apenas dois hectares ele produz e comercializa vinhos finos formalmente (Foto 48). $\mathrm{O}$ produtor diz enxergar várias falhas e questões que não ficaram claras na lei dos vinhos coloniais.

O vitivinicultor exemplifica que a lei, da forma como foi aprovada, não é interessante nem para ele nem para os produtores de vinho colonial. Rogério diz que produz 10.0001 de vinho/ano, e que segundo as regras da lei poderia se adequar a ela, mas não vê nenhuma vantagem. Diz que se a lei fosse conforme a proposta, com impostos mais baixos, possibilitando a venda com o talão do produtor rural, poderia ser interessante.

Outro ponto crítico que o produtor aponta sobre a lei é o fato desta restringir o comércio de vinhos coloniais às vendas dentro da propriedade ou em festivais. Ele estima que $30 \%$ dos 
seus vinhos são vendidos na propriedade, $50 \%$ despachados e os outros $20 \%$ são vendidos para lojas locais, o que tornaria inviável sua produção sob a égide da lei. Outras dúvidas que ele apresenta é sobre o selo fiscal, como seria feito? Como seria feito a fiscalização? Quais seriam as exigências mínimas de infraestrutura?

O produtor afirma que uma possível mudança benéfica ao setor seria se os vinhos de maneira geral fossem enquadrados como alimentos, como é feito por toda a Europa, e assim poderiam gozar do mesmo enquadramento do Simples. O agricultor aponta ainda que muitas normas são impostas, mas não tem justificativa, como a necessidade de um pé direito muito alto, a necessidade que pagar o conselho de química no mesmo valor que uma grande vinícola e ser obrigado a pagar um Engenheiro de Segurança do trabalho para supervisionar alguns procedimentos na vinícola.

Ao final da conversa Rogério Valduga cita que somente baixar os impostos não seria a medida correta. Ele argumenta que as lacunas da lei certamente seriam usadas pelas grandes vinícolas de forma oportunista. O produtor afirma que se os impostos fossem atenuados, possivelmente grandes empresas lançariam uma linha de produtos colônias e ele mesmo poderia venderia os $30 \%$ da produção na propriedade com o talão do produtor rural e vender o restante dos vinhos sob seu registro no MAPA.

A análise feita por Rogério Valduga é bastante pertinente, pois mostra que a simples medida demandada pela maioria dos produtores, de baixar os impostos, poderia ser usada pelas grandes empresas, transformado o vinho colonial num nicho de mercado onde as indústrias vinícolas teriam mais vantagens sobre os produtores coloniais. Fato este que, culminaria numa situação onde o Estado iria arrecadar menos das grandes empresas, haveria um aumento da fatia de mercado abrangida pelas grandes vinícolas e consequentemente, a diminuição da participação, representação e capitalização dos pequenos vitivinicultores.

Pensando sobre esse cenário descrito, é possível remeter à frase de George Bernard Shaw que diz que "para todo problema complexo, existe uma solução clara, simples e errada. 


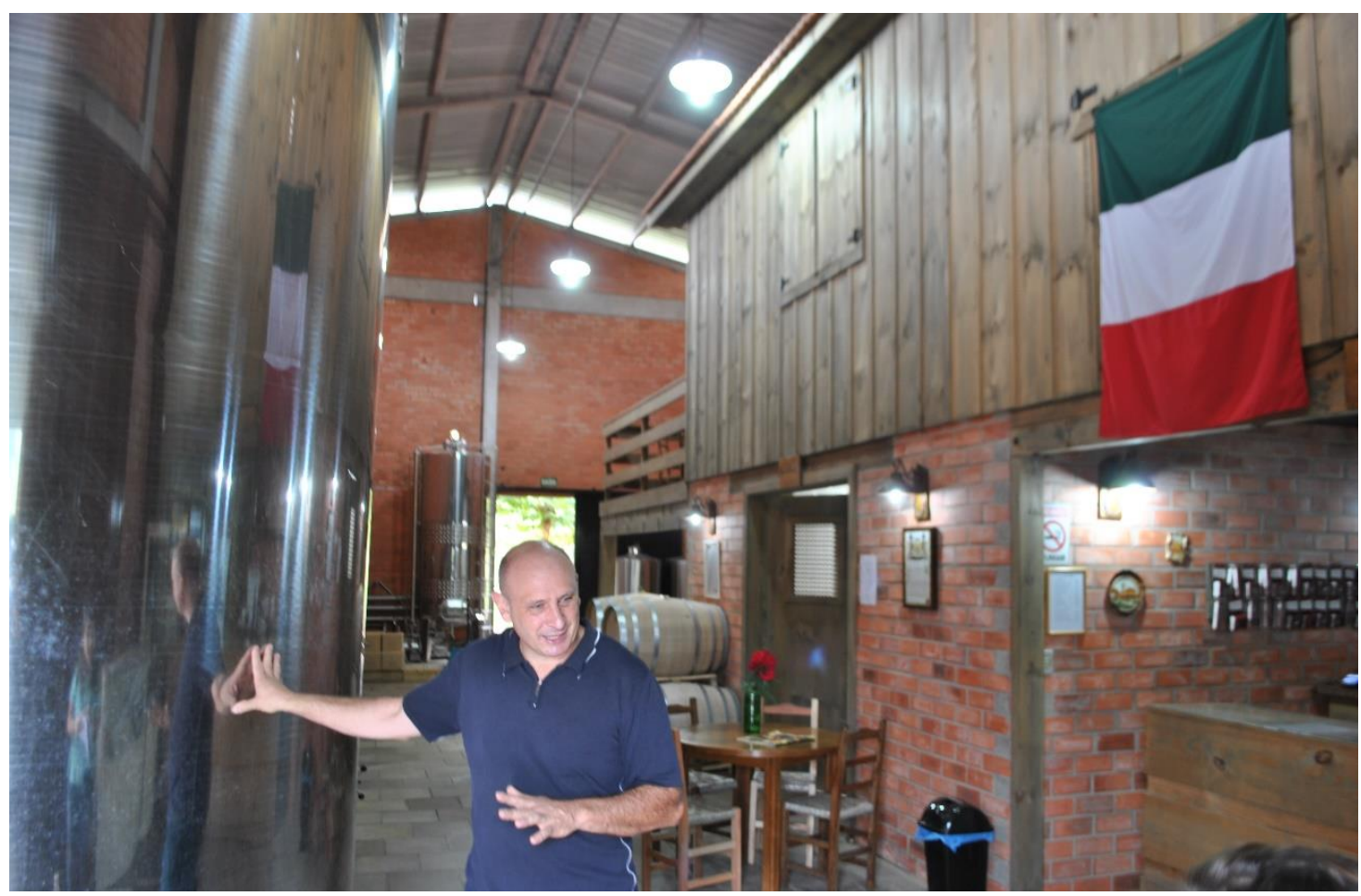

Foto 48: Rogério Valduga dentro da sua vinícola

Fonte: acervo do autor (2014)

Já na visita feita ao produtor Rui Todeschini e sua esposa Aide Todeschini (Foto 43), foram conversados sobre vários assuntos, mas quando o assuntou foi para as intervenções do estado na agricultura o casal afirmou que a agricultura no Brasil é "muito podada", explicando que esse é um dos motivos que tantos jovens da região não permanecerem na terra.

O senhor Rui Todeschini pondera que o vinho colonial deveria ser enquadrado na tributação do sistema Simples e que o Estado deveria fazer uma maior divulgação e valorização dos vinhos nacionais.

Com relação à lei do vinho colonial o produtor afirma, como a maioria dos produtores, que pouco incentivou os produtores, ele cita dois fatores que incentivaram o aumento na produção de vinho colonial: o primeiro é fator foi das industrias vinícolas adotarem um valor muito baixo para o quilo da uva e demorarem para pagar os produtores. O senhor Rui Todeschini diz que a produção de vinho e suco colonial foi a alternativa que os produtores encontraram para não ficarem tão dependentes da indústria. O segundo fator que o agricultor cita ter incentivado o aumento da produção dos vinhos coloniais foi o festival do vinho colonial, pois sente que o festival chama a atenção dos turistas para o vinho colonial e para a região. 
É possível inferir sobre os dois fatores que incentivaram o aumento da produção do vinho colonial, segundo o senhor Rui Todeschini que, o primeiro fator ocorreu segundo o princípio da "produção de vinho colonial como desobediência civil" onde os produtores se sentem explorados pelas indústrias, que subvalorizam o trabalho dos agricultores e o fazem de forma concedida pelo Estado, já que é a Conab que estipula os preços mínimos. O outro fator apontado pelo vitivinicultor é o festival do vinho colonial que foi uma ação feita em conjunto com várias instituições do Estado que atuam de forma local e não com grande abrangência como é feito pela lei do vinho colonial que é em âmbito nacional.

Essas possíveis interpretações feitas a partir do comentário do senhor Rui Todeschini são somadas à fala que o agricultor fez quando já estávamos em campo. Enquanto o produtor amarrava as parreiras, ele explicava seu ponto de vista sobre vários assuntos. Segundo o agricultor, "O problema do Brasil é que é um país muito grande e muito diverso, uma ação que dá certo num estado pode não dar certo em outro. Então se uma lei é feita para todo o país, algumas partes vão se encaixar outras não. A ações bem feitas são todas feitas localmente".

O Produtor Mateus Dalla Corte com 25 anos (Foto 49) é o produtor mais jovem visitado, sendo notório que ele tem uma visão otimista da lei dos vinhos coloniais. Segundo Mateus, a lei não está interessante para os produtores mas acredita que vai melhorar a questão do veto dado por parte do Ministério da Fazenda. Mateus diz que para ajudar no desenvolvimento local seria importante que fosse resolvida a questão do veto referente aos impostos cobrados e que os produtores pudessem vender com o talão de produtor rural. 


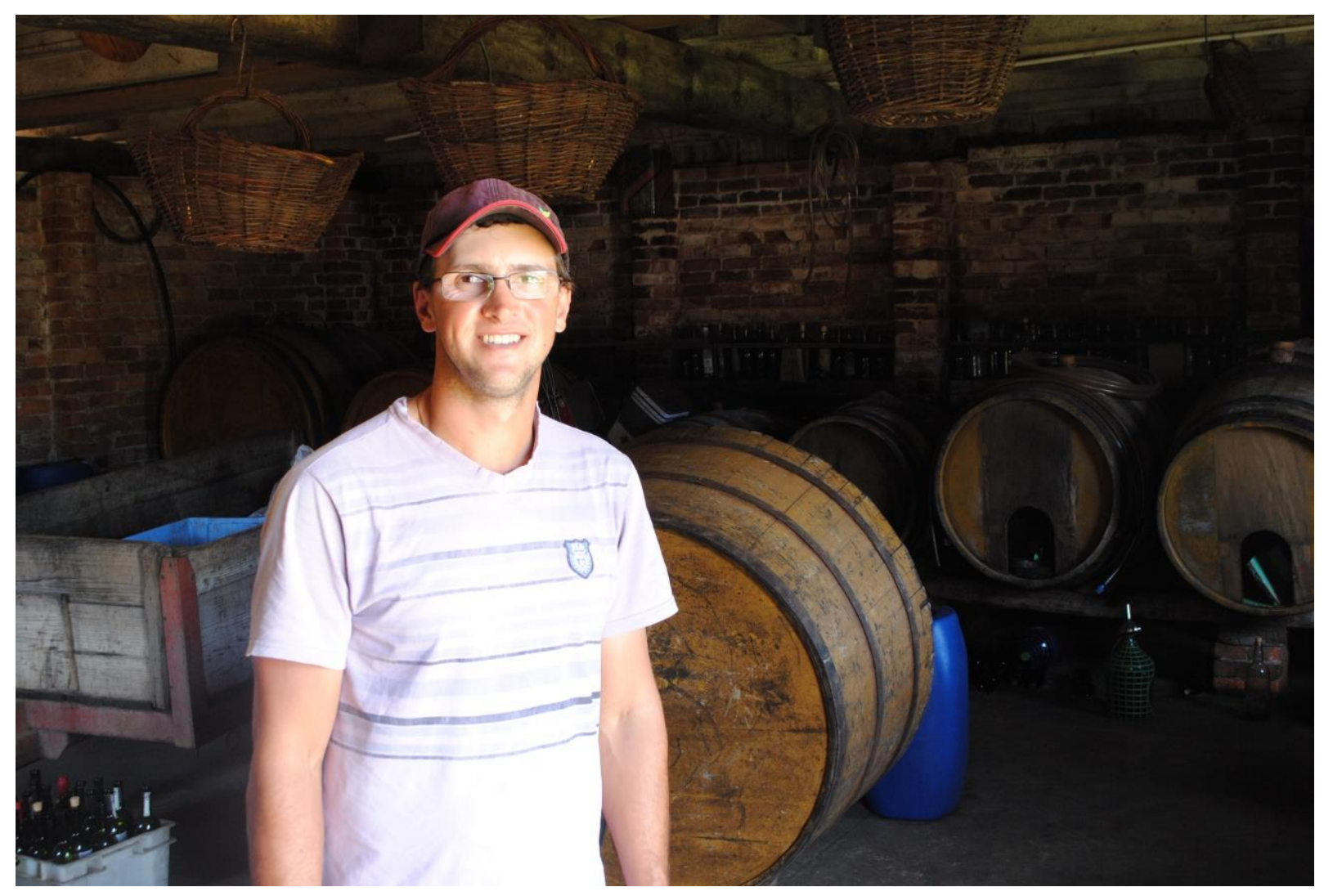

Foto 49: Mateus Dalla Corte, o produtor mais jovem em seu porão de vinhos

A visita planejada para ser feita aos produtores Zelavir Giordani e Genuíno Pastório se transformou numa produtiva conversa de almoço (Foto 50). Havia agendado com os dois produtores de ir até suas propriedades, no entanto como uma ótima surpresa, ambos os produtores foram ao encontro do enoturista-pesquisador que estava almoçando no restaurante Don Giordani, do filho do senhor Zelavir Giordani. Diferentemente das visitas realizadas com os outros produtores, nessa conversa acabamos nos atendo somente ao assunto dos vinhos.

Os produtores disseram que da forma que a lei foi aprovada nenhum produtor vai aderir, mas dizem que não cabe culpar a Presidenta Dilma, mas sim os responsáveis pelo veto. No entanto eles falaram que não caberia ficar pensando em quais forças poderiam ser contrárias à aprovação na íntegra da proposta da lei. Segundo eles poderiam haver muitos motivos e envolvidos.

O senhor Genuíno afirmou que a ganância por impostos por parte do Estado é o que faz como que eles acabem por produzir informalmente. Eles dizem que não gostam de estar produzindo fora da lei ou ilegalmente. Os produtores afirmam que a produção do vinho colonial já é uma realidade na região e no País. Dizem ainda, que os produtores não vão parar de produzir 
e eventualmente vender seus vinhos, mas gostariam de produzir legalmente, dentro da lei, no entanto, da forma como a lei está, ela é inviável.

Os produtores dizem que a ganância do governo em cobrar impostos é cega, pois se fosse possível comercializar com o "talão do produtor $\mathrm{n}^{\circ} 15$ " a maioria dos produtores iriam aderir à lei e iriam contribuir com os impostos e todos sairiam ganhando. Do contrário, com os impostos pesando sobre o produtor, não se faz acordo e continuamos a produzir informalmente.

O senhor Zelavir Giordani aponta que enquanto não for "um bom acordo" para os dois lados, os produtores irão continuar fazendo como sempre fizeram até hoje.

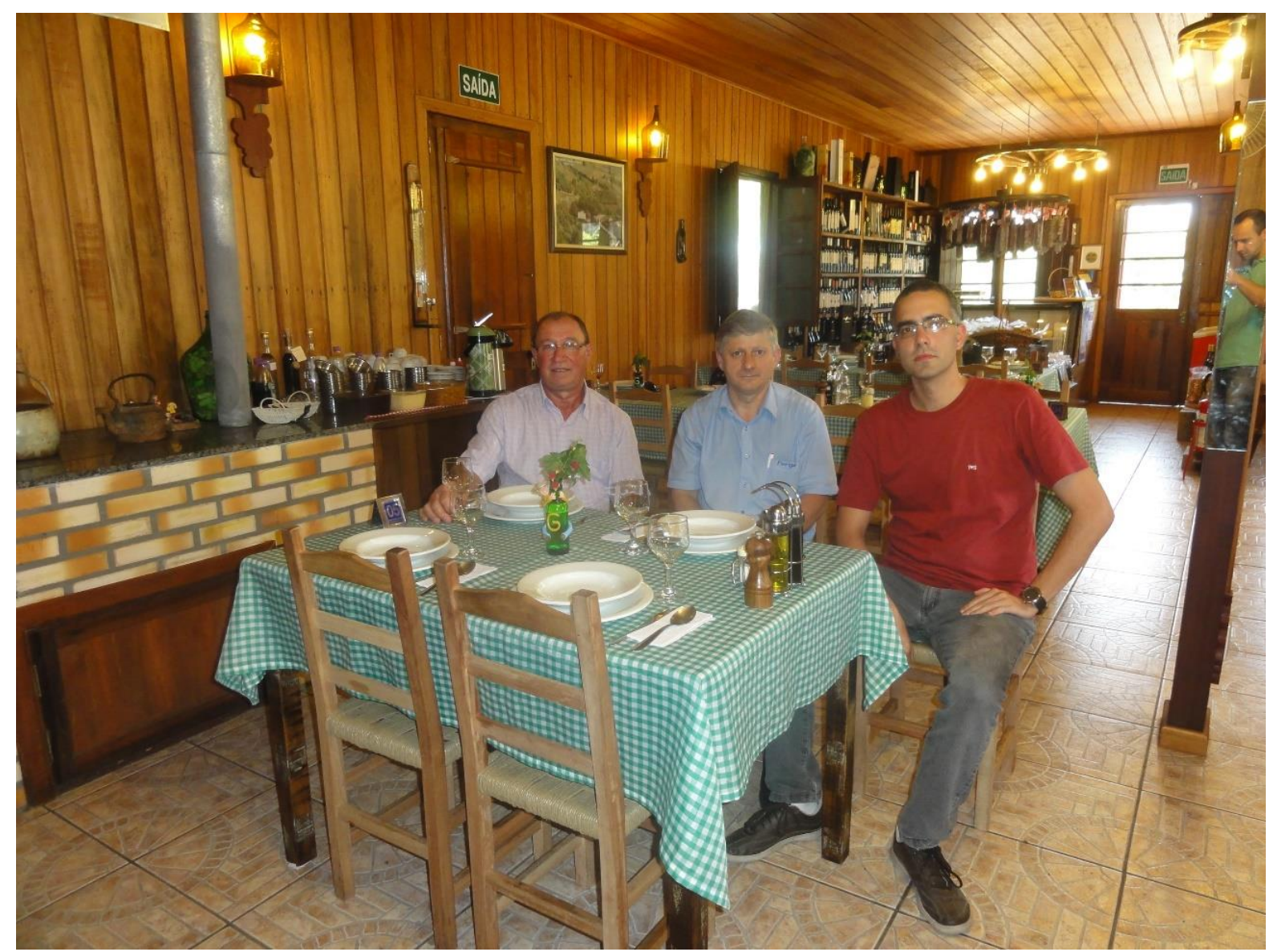

Foto 50: produtor Zelavir Giordani, Genuíno Pastório e o enoturista-pesquisador no Restaurante Don Giordani. Fonte: acervo do autor (2014)

A visita feita à propriedade do Produtor Carlos Alberto Batisttello foi feita no campo, com o produtor podando o parreiral junto com o produtor Marcos Patucci, como pode ser visto na foto 51. O agricultor Carlos Alberto fala que no Brasil os impostos dificultam a vida dos trabalhadores e pequenos empreendedores. O trabalhador explica que a tributação no Brasil é tão alta que faz com que um agrotóxico de uma empresa multinacional no Uruguai tenha o custo 
de $50 \%$ do valor do mesmo produto no Brasil, induzindo muitos produtores a fazer compras no exterior. O produtor diz admitir que é importante que se pague impostos para o desenvolvimento do país, mas questiona se é justo que um agricultor que compre 20 litros de insumos para sua produção em outro país acabe sendo preso e multado em $\mathrm{R} \$ 26.000,00$, com tem conhecimento de casos próximos na região. Ele diz que se a tributação não fosse tão alta sobre as indústrias os produtos certamente seriam mais acessíveis aos produtores.

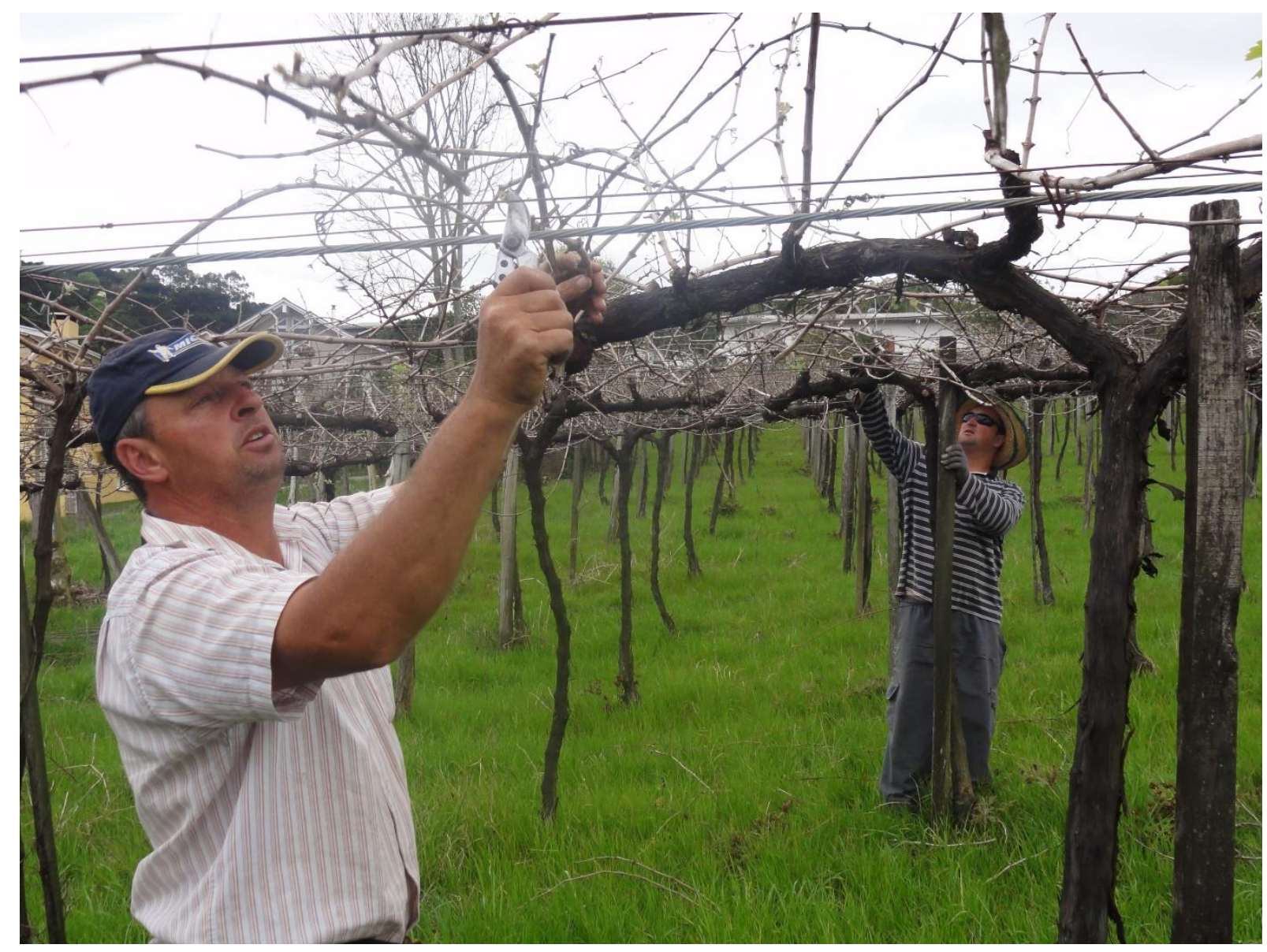

Foto 51: Carlos Alberto Batisttello e Marcos Patucci podando o parreiral

Fonte: acervo do autor (2014)

$\mathrm{Na}$ visita feita à propriedade de Luís Batisttello e Filhos, fui recebido pelos filhos Mateus e Marcelo Batisttello (Foto 44) que foram muito simpáticos com a pesquisa realizada, eles disseram, como todos os outros produtores coloniais, que a lei acabou que não os ajudou, mas dizem que estão produzindo vinho colonial inicialmente, mais dizem ter vontade de oficializar a produção pois estão investindo e trabalhando para se possível a alguns anos se tornarem uma vinícola formal e a partir de então passarão à produzir pagando toda tarifa incidente sobre os vinhos das vinícolas. 
A visita ao produtor Pedro Valiatti ficou acordada de ser feita às 16:00 horas, no entanto o enoturista-pesquisador chegou na propriedade do senhor Pedro Valiatti com antecedência de meia hora e deparou-se com a nobre cena do produtor Pedro Valiatti lavrando com seu filho Mauro Valiatti, como mostra a foto 52.

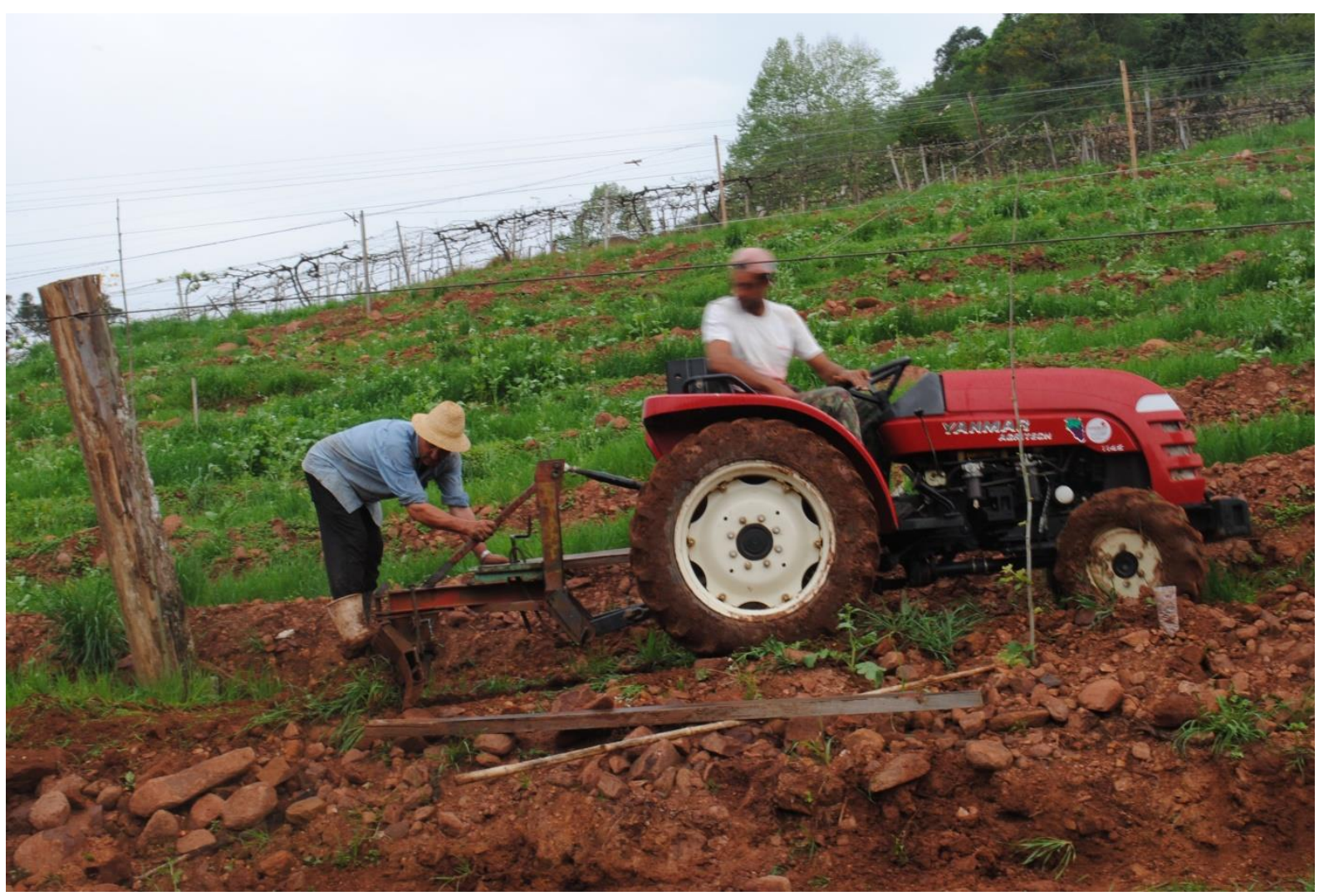

Foto 52: Pedro e Mauro Valiatti, Pai e filho lavrando o solo

Fonte: acervo do autor (2014)

Nessa visita conversamos bastante sobre o vinho colonial e produtor Pedro Valiatti criticou a forma como a lei foi feita, segundo o produtor os 20.000 litros adotados pela lei é uma quantidade muito alta para produtores coloniais. A Senhora Lurdes, esposa no agricultor, ponderou que seria mais interessante se o valor máximo de produção fosse de 10.000 litros e a questão da venda com o talão do produtor rural fosse aprovada. Segundo a produtora, essa seria uma medida que ajudaria os pequenos produtores que realmente necessitam de apoio.

Toda a família Valiatti concorda quando o vitivinicultor Pedro Valiatti afirma que o vinho colonial não faz mal para a saúde, até por que são os produtores os principais bebedores desses vinhos, e normalmente os produtores tem uma vida longa e saudável acrescenta Mateus Valiatti. A senhora Lurdes estima que aproximadamente 1.000 litros de vinho são bebidos em 
sua casa entre alimentação diária e eventuais visitas, volume esse que representa um terço de sua produção anual.

O Senhor Pedro Valiatti confirma que o vinho colonial é uma bebida de tradição e cita que "só produz vinho quem bebe vinho, pois do contrário não iria produzir. Para produzir vinho tem que ser apaixonado pelo vinho".

Eles cogitam a possibilidade de que se os impostos não fossem tão altos, possivelmente as indústrias que compram suas uvas, remunerassem melhor os produtores pela venda de suas uvas. A visita à Família Valiatti foi a propriedade de mais difícil acesso das visitas feitas. O Produtor Pedro Valiatti foi o primeiro produtor que afirmou que sabe da importância do enoturismo na região, mas diz não estar interessando em investir no enoturismo, justificando seu desinteresse pelo fato de sua propriedade ser longe da rota turística do Vale dos Vinhedos.

O enoturista-pesquisador tirou uma foto com a família Valiatti ao final da visita quando todos os integrantes da família estavam presentes, como mostra a foto 53.

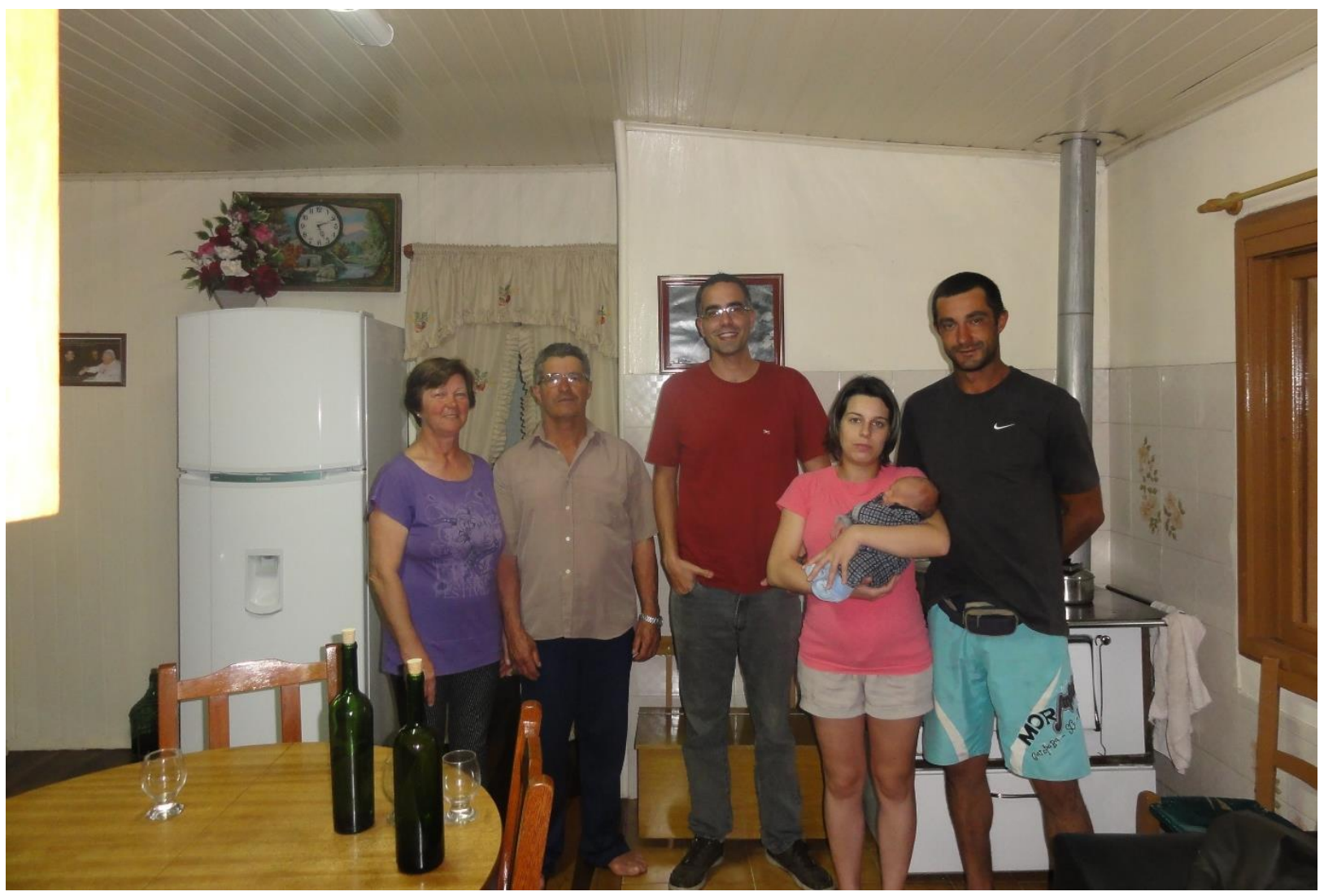

Foto 53: família Valiatti (Lurdes, Pedro, Camila segurando Pedro Henrique e Mauro) com enoturista-pesquisador. Fonte: acervo do autor (2014) 
Na Visita realizada à propriedade do produtor José Milani, ele apontou que vem acompanhado desde o início o trabalho que a Emater vem fazendo sobre os vinhos coloniais na região. O produtor diz que a Emater vem trabalhando com os produtores por 3 ou 4 anos o tema do vinho colonial como uma forma de resgate de tradições. Ele confirma a fala da socióloga Maria de Lurdes, que o trabalho da Emater se deu desde no início tratando sobre a conscientização dos produtores sobre a importância de resgatar e fortalecer o tradicional ofício da vinificação de vinhos coloniais, depois passaram para uma segunda etapa onde eram abordados aspectos referentes à cultura e condução das videiras viníferas. Após essas duas etapas, no terceiro ano foi abordado temas relacionados a técnicas enológicas e de vinificação.

O produtor José Milani aparenta ter algum destaque entre os produtores da região, pois frequentemente era referenciado por outros produtores com um entendedor do assunto.

A conversa com o produtor José Milani foi muito produtiva, o agricultor tem uma visão bastante positiva do futuro da lei do vinho colonial, ele afirma que de fato da forma que a lei está não é interessante para os produtores. Como ele mesmo diz "a aprovação da lei foi um verdadeiro balde de água fria", mas acredita "que o veto será revisto e aprovado". O produtor diz que já havia dito nas reuniões realizadas para discutir a lei dos vinhos coloniais que 20.000 litros é um volume muito alto, diz que para ser realmente um pequeno produtor deveria ser uns 10 ou 15.0001 .

O produtor pensa que seria melhor aprovar a lei com o limite de 10.000 litros/ano com a possibilidade de comercializar com o "Talão do produtor $\mathrm{n}^{\circ} 15$ ". Após essa afirmação o agricultor mostrou como é um talão do produtor rural (Foto 46). O agricultor critica também o fato de a lei autorizar a pessoa a poder comprar 30\% da produção. Diz que "não deveria ser assim".

José Milani revelou que já foi em várias reuniões da Aprovale e diz que os donos das grandes vinícolas são mal vistos pelos pequenos produtores, pois inicialmente tratavam com os pequenos produtores que plantassem uvas de determinadas variedades pois iriam comprá-las no futuro, no entanto, depois de alguns anos passaram a oferecer valores muito baixos, isto é, quando ofereciam a intenção de compra. Essa afirmação já havia sido feita pelo senhor Henrique da Famiglia Tasca.

O produtor José Milani diz que a Aprovale não é favorável à produção de vinhos coloniais. Ele explica que a Aprovale é constituída pelos produtores da região que já estão 
comercializando seus produtos e serviços de maneira regular, mas o que ocorre, segundo o produtor, é que a Aprovale é regida por duas ou três empresas que são as maiores vinícolas da região. O agricultor conclui dizendo que os "grandes cantineiros" do vale são contra a aprovação da lei e cita que um dos membros da Aprovale ficou irritado ao receber o convite do primeiro Festival do vinho colonial, pois dizia que só no Brasil é possível fazer um festival da ilegalidade.

$\mathrm{O}$ agricultor afirma que tem interesse em explorar o enoturismo, mas pondera sobre o desenvolvimento do enoturismo na região, segundo o ele " $O$ turismo não se faz com uma ou duas empresas, mas sim com toda a comunidade". Ele explica que só com o envolvimento de toda a comunidade geraria melhorias para a região, pois assim a população passaria a investir mais e passariam a pintar e cuidar melhor da área externa de suas casas e casarões para a região ficar mais bonita e melhor cuidada. O produtor reitera que "O turismo quer atrações, e os produtos coloniais são outros tipos de atrações que a região pede".

O produtor diz ter interesse em investir no enoturismo, mas para isso é necessário que a lei seja revista e aprovada. Mesmo na informalidade, os produtos coloniais são produzidos para a subsistência, mas quando os turistas chegam demandando por produtos coloniais, os produtores acabam vendendo pois é uma renda a mais. Segundo José Milani, “muitas pessoas saem perguntando pelas casas até encontrarem alguém que esteja vendendo e normalmente quando compram já voltam direto no produtor".

No final da visita fez questão de mostrar sua área de vinificação que é no porão do casarão antigo. O produtor lamenta não poder dar mais atenção para o casarão, ele diz que deixar aquela casa se desfazer seria um "pecado", pois além de ser muito bonita, tem um valor sentimental por ela, pois foi naquela casa que ele e seu pai nasceram (Foto 54). 


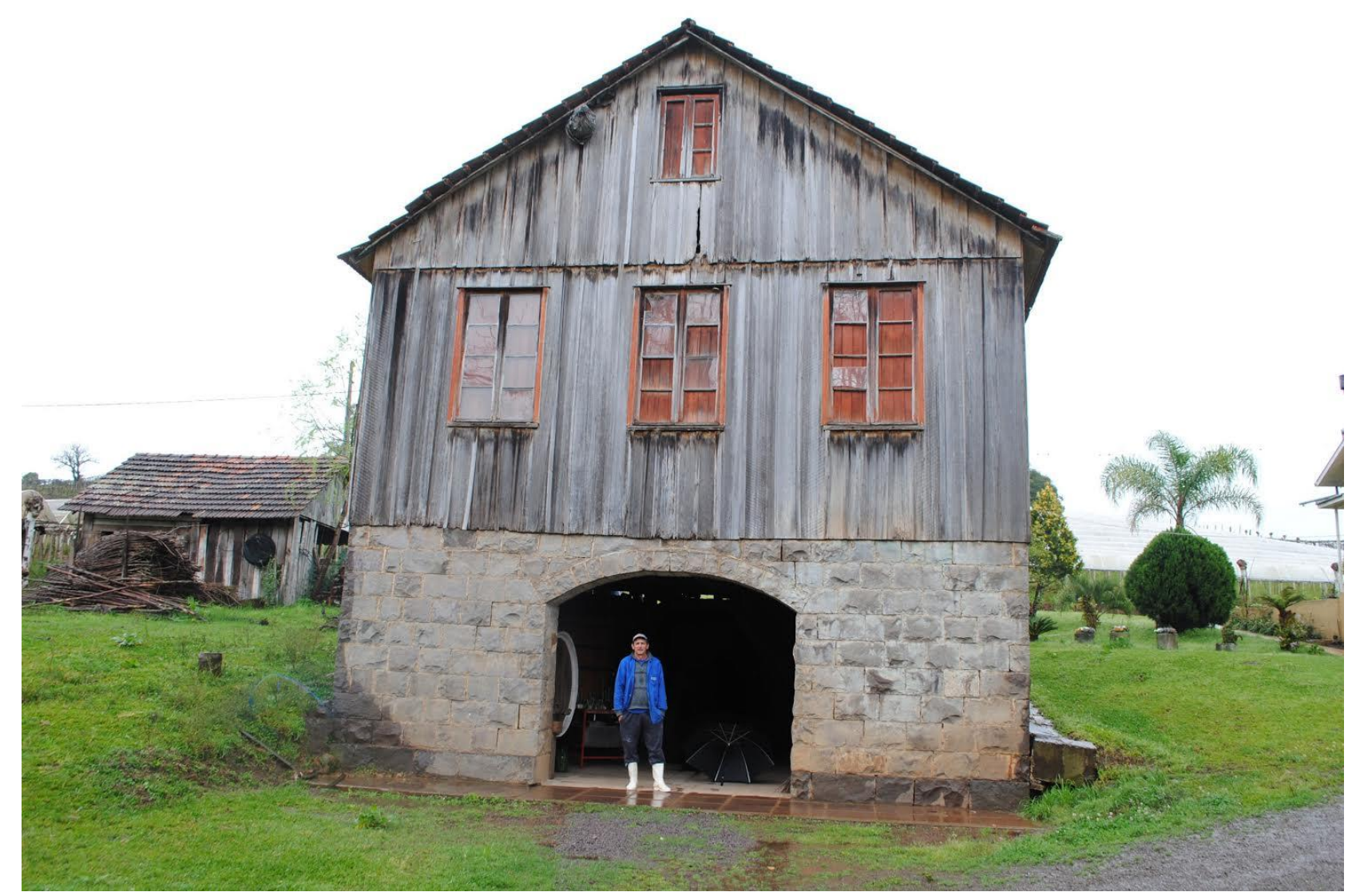

Foto 54: José Milani em seu porão de fabrico de vinhos coloniais

Fonte: acervo do autor (2014)

O último produtor a ser visitado foi o produtor Vitório Somensi. Essa última visita foi feita na companhia do Senhor Sandro Giordani e da pesquisadora italiana Ornella Maiutto. Durante o caminho da propriedade do senhor Vitório Somensi, o senhor Sandro Giordani havia dito que existe uma parceria de produção entre o produtor Vitório e Jaime Zandonai como fica evidente no banner do festival do vinho colonial do ano passado na foto 55 . 


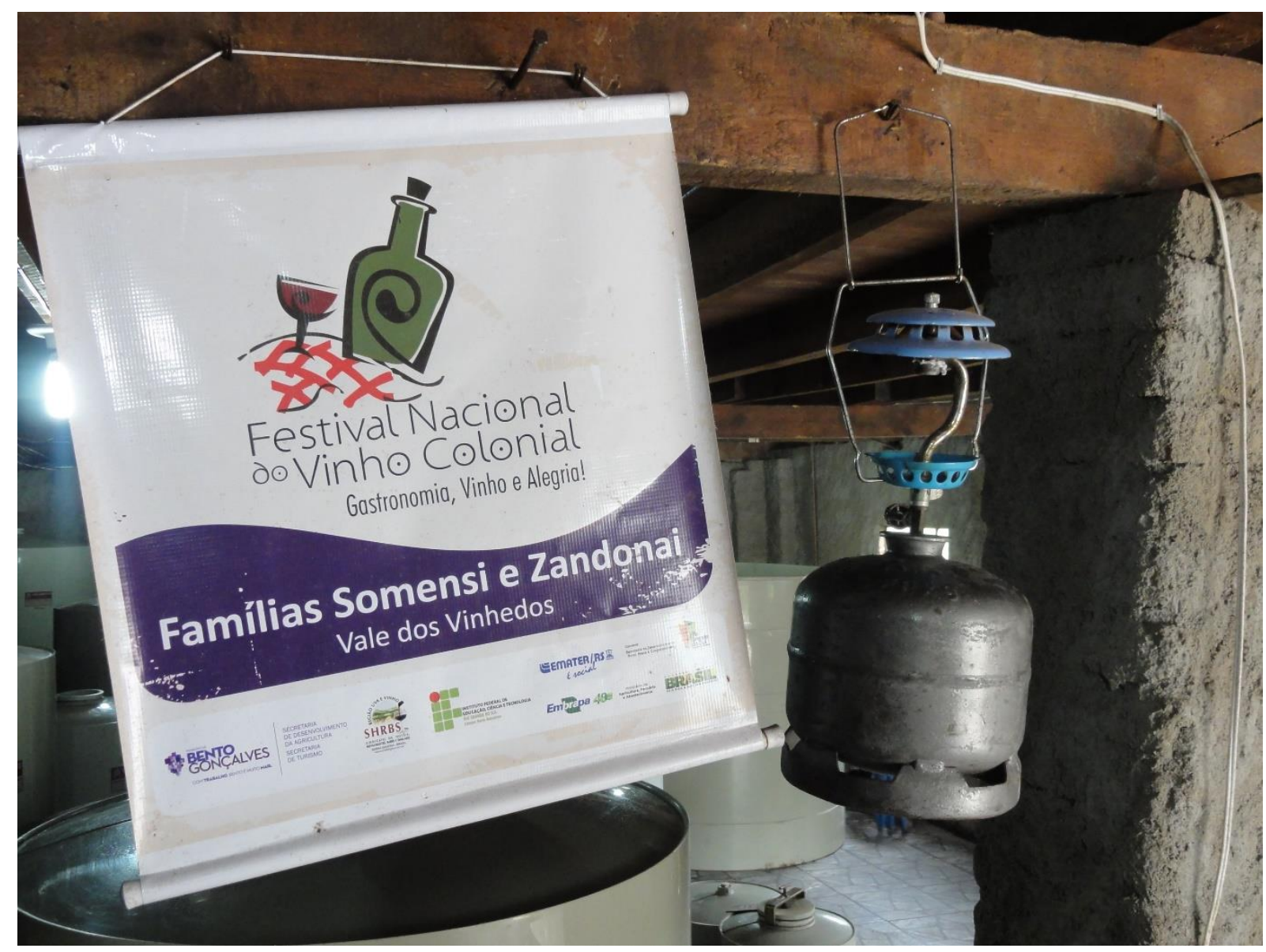

Foto 55: banner das Famílias Somensi e Zandonai no primeiro festival nacional do vinho colonial. Fonte: acervo do autor (2014)

Na visita à propriedade o senhor Vitório Somensi explicou que aquela produção era conjunta com o senhor Jaime Zandonai e outros amigos. $\mathrm{O}$ agricultor disse que frequentemente o Senhor Jaime vai até a propriedade com seu amigo enólogo e lá fazem diversos testes na elaboração dos vinhos. Isso talvez explique o motivo de haver tantos recipientes para acomodar vinho de menor volume, conforme mostrado na foto 42. O senhor Vitório tem sua opinião concordante com a maioria dos produtores visitados, quando diz que a coisa que mais ajudaria os produtores seria rever o veto dos impostos, no entanto é franco ao dizer que não tem interesse em investir no enoturismo. Ele explica que sua propriedade é distante e de difícil acesso, mas acredita que o enoturismo seja boa alternativa para os outros produtores de vinhos coloniais. $\mathrm{O}$ agricultor cita que a região tem vários pontos turísticos e foi nos mostrar a paisagem com a queda d’água, como mostra a foto 56. 


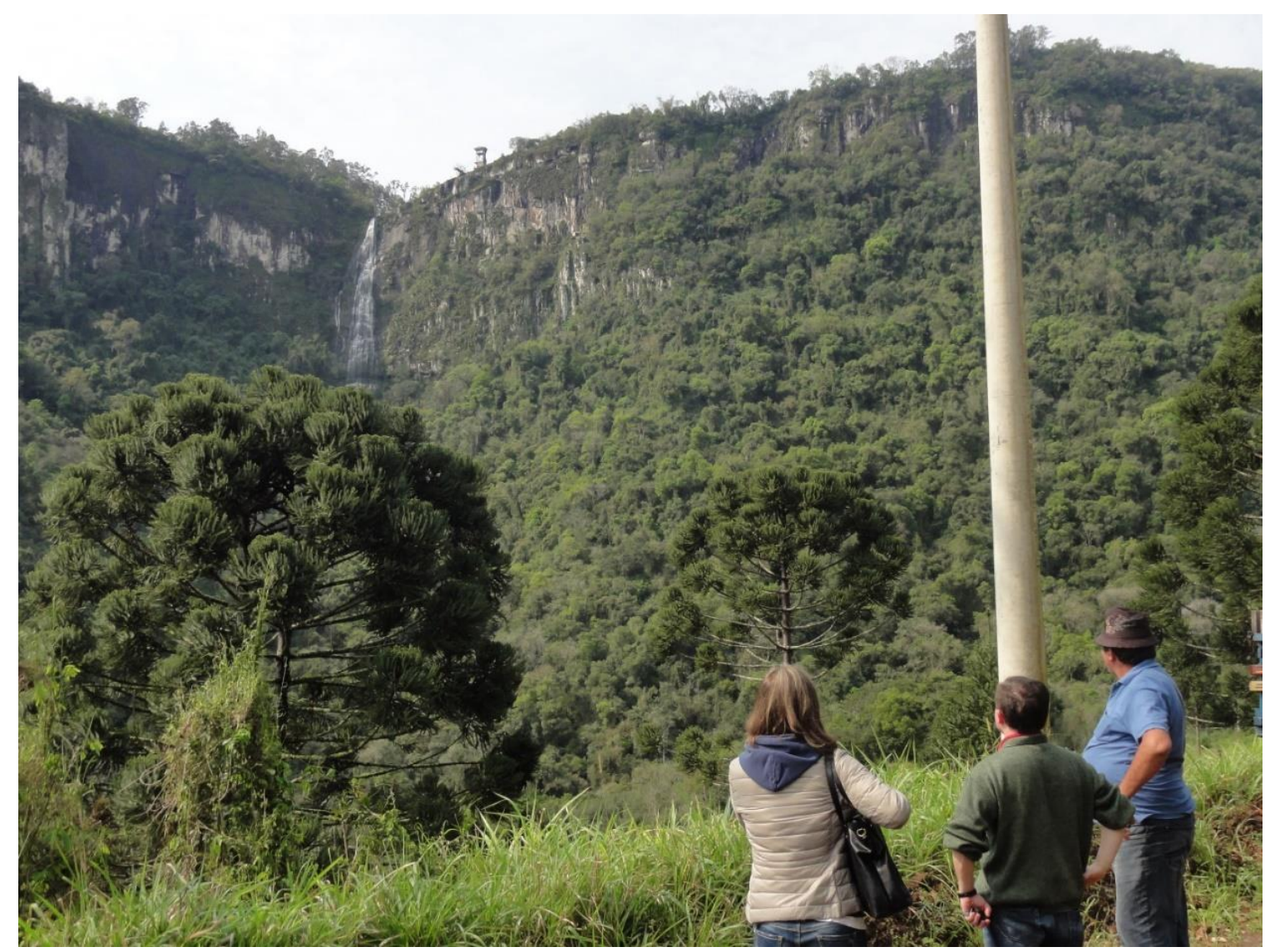

Foto 56: Ornella Maiutto, Sandro Giordani e Vitório Somensi observando a paisagem

Fonte: acervo do autor (2014)

\subsection{PARAlElo ENTRE O LIVRO "COLONOS DO VINHO" DE JOSÉ VICENTE} TAVARES DOS SANTOS E O OBSERVADO NAS VISITAS AOS PRODUTORES DE VINHO COLONIAL DA REGIÃO DO VALE DOS VINHEDOS

No livro Colonos do Vinho, Santos (1984) trata de maneira fulcral a subordinação do trabalho camponês ao capital. Durante a leitura do livro foi possível notar várias semelhanças e diferenças entre o estudo realizado durante os anos de 1972 e 1973 na mesma região do presente trabalho.

Logo no início do livro já foi possível notar a primeira similaridade entre as pesquisas que foi a opção da metodologia de pesquisa de campo. $\mathrm{O}$ autor aponta que fez entrevistas informais com os produtores e extensionistas e estudiosos dos assuntos relacionados. As entrevistas informais foram igualmente feitas no atual estudo com o mesmo objetivo de dar liberdade aos produtores, de maneira que encarassem a entrevista ou visita como uma conversa e não como uma entrevista com perguntas direcionadas. 
É interessante a forma com que José dos Santos aborda a informalidade, quase nata dos produtores de vinho colonial. Ele aponta que além da produção informal dos vinhos coloniais, existe uma não subordinação do trabalho do camponês à indústria; outro aspecto que demonstra a posição subversiva dos colonos é o fato de falarem em italiano ou no dialeto falado no norte da Itália.

Em conversa com uma professora da região, esta havia dito que durante alguns anos os imigrantes em geral foram proibidos de falar qualquer língua que não fosse o português. $\mathrm{O}$ autor cita que após o período da Segunda Guerra Mundial, o então presidente Getúlio Vargas, com o “espírito nacionalista” proibiu o uso público de outras línguas, e foi a partir de então que se concretizou o bilinguismo da região, onde dependendo da formalidade era usada uma ou outra língua.

O autor divide com o leitor a experiência que teve durante sua pesquisa, de travar alguns diálogos no dialeto norte italiano que aprendeu a falar com os colonos. O enoturista-pesquisador teve experiência parecida quando estava acompanhando a pesquisadora Ornella Maiutto à vinícola Barcarola e o senhor Cesar Petrolli, com o intuito de fazer com que a pesquisadora italiana se sentisse mais à vontade, iniciou um diálogo em italiano. O diálogo foi travado entre Ornella, Cesar Petrolli, Sandro Giordani e o enoturista-pesquisador.

O livro aborda o tema da imigração de agricultores para substituir a mão de obra de escravos. Inicialmente o autor cita que a vinda de imigrantes para o Brasil não foi uma estratégia política sem atritos ou consensual entre os grandes interessados na questão agrária.

A conjuntura econômica favorecia o Rio Grande do Sul a opção pela colonização e a tendência a substituir a escravatura e a monocultura ganadeira pelo braço livre, a pequena propriedade e a agricultura, se não para substituir inteiramente a criação de gado, que era a base da economia da Província, ao menos para completar uma economia com a outra. (AZEVEDO, 1975 apud SANTOS ,1984, p. 14).

O autor cita ainda que o movimento pró imigração e colonização era advindo de um "pensamento inovador no seio das classes dominantes, opondo-se ao pensamento conservador dos proprietários de escravos e charqueadas do sul do Estado" (p. 14). Contribuindo com as afirmações anteriores, a veterinária Martina Bastos havia explicado em uma conversa na Feira Agropecuária Expointer sobre as diferenças que ocorrem dentro do Rio Grande do Sul sobre o tamanho médio das propriedades no estado. Segundo ela, a região mais a oeste do estado foi 
colonizada basicamente por portugueses e espanhóis, já as regiões centro e nordeste por italianos, alemães e poloneses. Ela cita que, dependendo do tipo de colonização da região, existem variações das culturas das regiões, explicando que em regiões de colonização portuguesa e espanhola tendem a gerar latifúndios com monoculturas ou pecuária ao passo que regiões colonizadas por povos italianos, alemães e poloneses tendem à produção diversificada sob agricultura familiar em pequenas propriedades.

É interessante notar que a explicação da veterinária é consoante com a fala do autor, onde a região sul do estado, adotada pelo autor, é a mesma região oeste do estado tratada pela veterinária e, não por acaso, é na região Nordeste do estado que existe a Embrapa Uva e vinho na cidade de Bento Gonçalves e na região sul/oeste do estado está sediada a Embrapa Pecuária Sul na cidade de Bajé (EMBRAPA, 2014).

Voltando para os destaques feito no livro sobre a questão da imigração, o autor cita que as ações do Estado em favor da imigração e colonização desses imigrantes eram não somente para resolver o problema da mão de obra escassa naquela época, como almejava-se por uma renovação das práticas de trabalho no Brasil e “esperava-se a libertação do espírito criador de trabalho, milagre que só o imigrante, isto é, o braço estrangeiro livre, proprietário, e não peado pelas velhas formas de produção" (p.14).

O autor acrescenta ainda que parte do pensamento das classes dominantes determinavam que "a colonização deveria ser feita por braços livres e brancos, cristalizando também na província a ideologia do "branqueamento" do país" (p. 15).

Se por um lado alguns pensadores da época acreditavam na colonização de áreas inabitadas, o autor cita que havia pressão por partes dos interesses dos grandes produtores de café, leite e laranja para que esses imigrantes viessem simplesmente para substituir a mão de obra escrava.

É interessante observar a similaridade atribuída aos produtores coloniais dada neste estudo de caso e no livro "Colonos do Vinho". Como já foi apresentado a ideia que o trabalho dos produtores coloniais é uma forma de produção pré-revolução industrial, pois tende a romper, pelo menos em parte, com a dinâmica da exploração do trabalho dos agricultores pela indústria, o autor cita em seu livro que os produtores coloniais são personagens não especificamente capitalistas, pois não trabalham na terra em troca de salários, tem autonomia sobre os fatores de produção e não são considerados como um dos fatores/insumos para que haja produção, pelo contrário, produzem mercadorias e são criadores de trabalho excedente. 
Outra realidade que pôde ser vista entre os agricultores coloniais do Vale dos Vinhedos e que foi retratada no livro foi a questão do trabalho acessório. Trabalho acessório como é definido no livro, é quando o produtor trabalha fora da sua propriedade assumindo a forma de trabalhador assalariado, podendo ser tanto em outras propriedades rurais ou em obras de construção civil.

Foi observado a transformação da força de trabalho colonial em trabalho acessório com o produtor Maikon Panizzi, que no final da visita disse que se houvesse necessidade de tirar alguma dúvida que estava à disposição de ajudar, mas sugeriu que ligasse sempre no final do dia pois naquele período estava trabalhando como pedreiro. Confirmando assim que a transformação de trabalho colonial em trabalho acessório ainda é usual entre os produtores de vinhos coloniais, tal qual abordado no livro.

Uma questão apontada pelo livro que se mostra diferente na atualidade da região do Vale dos Vinhedos é referente ao uso de agrotóxicos e mecanização. Primeiramente, quanto ao que se refere ao uso de agrotóxicos, infere-se que a Emater regional teve um papel fundamental na mudança da cultura e forma de produção atual. O livro trata da maneira como os produtores enxergam o uso dos agrotóxicos como uma maneira de tornar o trabalho no campo mais fácil. Alguns relatos dos produtores do livro deixam claro que o uso de herbicidas para conter as "plantas daninhas" é visto com muita simpatia pelos produtores da época, principalmente pelo fato de diminuir consideravelmente o trabalho da capina dessas ervas que nasciam no parreiral.

Conversando com os produtores de hoje, eles falam do trabalho da Emater em desestimular o uso daqueles herbicidas que já foram até incentivados por técnicos da mesma empresa e outros técnicos no passado. O produtor Jandir Crestani diz que foi estranho para ele aceitar que o parreiral estaria bem cuidado mesmo com "os matos crescendo". A Emater faz um trabalho de mudança de consciência dos produtores, demostrando que um parreiral bem conduzido deve permanecer com o solo sempre coberto por material vegetal, ao contrário do que era concebido anteriormente.

Da mesma forma que houve diferenças nas relações com o uso de agrotóxicos, nota-se diferenças no uso de maquinário entre os colonos. Mesmo não sendo uma região onde os solos são facilmente mecanizados, atualmente os produtores contam com pequenos implementos agrícolas que já ajudam bastante na lavra. O fato dos produtores atuais contarem com a ajuda de mecanização agrícola é bastante compreensível e não causa espanto, principalmente por 
esses mecanismos atualmente terem um preço mais acessível que anteriormente e os produtores contarem com linhas de crédito no Banco do Brasil para aquisição de equipamentos agrícolas.

Já o uso de adubos orgânicos permanece idênticos à forma como era feita nos anos de 1972 e 1973, quando foi realizada a pesquisa do livro. O autor usa o testemunho do colono ao explicar as vantagens do adubo orgânico: "Que aquilo é o melhor adubo que existe. E é melhor porque tem duas vantage. Porque é o melhor adubo e melhor herbicida. No mesmo tempo, aduba a parera e segura a parera limpa" (p. 58). Neste fragmento deixa claro as vantagens do uso de adubos orgânicos advindos das mais variadas formas e acessíveis aos colonos. Em visita à propriedade do produtor Mateus Dalla Corte, este explicou as mesmas vantagens apontadas pelo entrevistado do livro e ainda ressaltou que nada se perde na produção. Quando as podas do plátano estão sobre o solo, podem virar adubo ou lenha para a aquecer a casa.

O produtor Mateus Dalla Corte acrescenta outros dois pontos consoantes com o livro, o primeiro é que o produtor diz usar o mato que cresce ao lado de sua propriedade como material orgânico para fazer a cobertura do solo que atuará com as mesmas vantagens que o colono entrevistado no livro cita. A segunda observação que o produtor faz é com relação ao vime. Mateus Dalla Corte diz que as áreas com vegetações não plantadas são ainda muito importantes para o colono, pois é destas áreas que eles retiram o vime que usam para múltiplas funções.

Existe um capítulo do livro colonos do vinho que trata sobre "A Jornada de trabalho", nesse fragmento do livro é tratado como é árduo o trabalho no parreiral. O autor evidencia esse fato na fala do colono:

"a vida na colônia é braba; e se a gente non trabalha non tem nada. Tem que trabalha pra vive. Non é manso non trabalha... A roça é uma vida tristeza. Non é vida boa a roça, non. Quando que é noite, a gente tá cansado que non dá nem pra dormi. Com a enxada, todo dia" (SANTOS, 1984, p. 61).

É bastante compreensível que o trabalho rural seja cansativo, no entanto o fragmento acima vem se somar ao que já foi dito sobre o legado do trabalho colonial, e explica em parte um dos motivos do atual êxodo rural dos mais jovens. Ao final do livro existem alguns trechos em que os colonos dizem não ter interesse em trabalhar na cidade, principalmente pelo fato de perder sua autonomia como pode ser visto no fragmento seguinte:

"Porque se for pra sai da colônia e í pra cidade trabalha, é melhor que fica na colônia. Í pra cidade trabalha de empregado, a gente tem que tá na hora certa de manhã, de meio dia e de noite. Em veiz aqui non. Se eu quero começa trabalha 
oito hora, começo; quero descansá o dia, descanso. Ninguém manda em mim” (SANTOS, 1984, p. 156).

A partir desse fragmento, o autor define que nesse caso "o trabalho assalariado é a negação dessa autonomia" é também possível propor sobre essa fala que da mesma forma que o produtor não quer perder sua autonomia, ele não quer se submeter à exploração da produção industrial. Sendo assim, é possível propor mais um argumento que o trabalho dos produtores de vinhos coloniais é realizado sob um modo de produção pré-revolução industrial.

Sobre a dinâmica que os colonos comercializam primeiro seus produtos e compram outros produtos com o dinheiro das vendas, o autor trata que essa dinâmica de capital se dá sob o ciclo "mercadoria-capital-mercadoria", como ele trata como circulação simples de mercadorias, uma vez que a mercadoria é retirada da esfera da circulação e entra para a esfera do consumo individual. $\mathrm{O}$ autor afirma que os produtores coloniais compram somente aquilo que não produzem, ao passo que todos os produtos que produzem são primeiramente voltados para a subsistência e o excedente é comercializado. É a partir desse raciocínio que José dos Santos propõem que a economia camponesa ocorre de duas formas: produção de meio de vida e produção de mercadorias.

A forma de produção de meios de vida é basicamente a forma que foi exposta anteriormente, onde os produtores coloniais produzem uma gama de produtos e consomem de todas essas variedades. A relação dos agricultores consumirem todas as qualidades de produtos produzidos por eles pode parecer óbvia sob um olhar distante da agricultura atual, no entanto, com a tendência da produção sob monocultura especializada, o que é o mais usual na atualidade, é o agricultor produzir produtos que não são consumidos por ele e sim produtos que são tratados como mercadoria. É a partir dessa transação que o agricultor pode comprar aquilo que consome, caracterizando assim a forma de produção de mercadorias. O livro trata que os produtores de vinho colonial usavam as duas maneiras que produção, tanto a maneira de produção de meio de vida como a produção de mercadorias.

A afirmação anterior permanece atual, o relato dado pelo produtor José Milani pode confirmar essa realidade. $\mathrm{O}$ agricultor diz que a propriedade é a principal fonte de alimentos para a família. Ele acrescenta ainda que não teria condição de comprar carne suficiente para alimentar sua família de dez pessoas, pois o preço é muito alto e "o rendimento da carne é baixo", por isso tem criação de animais além da lavoura. Da mesma forma que o agricultor produz vários tipos de alimentos para subsistência da família, ele produz uvas de mesa, que até 
poderiam ser consumidas pela família do agricultor, mas a função principal dessa atividade é a comercialização dessas mercadorias e capitalização. Desta forma, fica assim proposto que aquelas ponderações feitas pelo autor no ano de 1972 sobre as duas formas de produção dos produtores de vinhos colônias continuam vigentes.

Assim como a lei do vinho colonial foi aprovada sem a aprovação dos vitivinicultores coloniais, e estes acabaram optando pela produção informal, houve no passado uma situação parecida. Em 1929 foi fundado o Sindicato Vitivinícola Rio-grandense LTDA, que era mais conhecido pelos envolvidos como "Sindicato do vinho". Basicamente o objetivo do sindicato do vinho era defender os interesses dos viticultores, atuando de forma a centralizar as atividades vitivinícolas como comercialização e fabricação. Uma das técnicas adotadas para controlar a fabricação seria a obrigatoriedade da venda exclusivamente para o sindicato que iria "standadizar" (padronizar) a produção dos vinhos do Rio Grande do Sul, "promovendo uma industrialização racional" incentivando "a reforma das instalações existentes e realização de novas e modernas, e instalando um laboratório de analyses".

O sindicato tinha um acordo com o governo do estado, que fixaria um preço mínimo interessante para os produtores, mas por outro lado o Estado fiscalizaria a produção das propriedades integradas ao sindicato, ficando obrigadas a aderir aos parâmetros exigidos pela fiscalização. As exigências da fiscalização obrigavam que os produtores cumprissem as mesmas questões que o sindicato incentivava. Uma das reivindicações do sindicato e exigência do Estado era o fim das cantinas nos porões das casas, fato esse que desagradou muitos produtores coloniais, como mostra o fragmento do livro:

\footnotetext{
"Depois pra fazê a cantina, meu pai lá, tinha casa em cima, embaixo tinha cantina, né. Enton o sindicato non queria mais moradia em cima do vinho. Pura cantina queria. Tem a pipa e a gente mora em cima, non podia mais fazê vinho. Ele feiz isso pra gente pegá e vendê a uva. Enton, começô a vendê uva" (SANTOS, 1984, p. 82).
}

O autor do livro tem uma visão bastante crítica sobre essas exigências do sindicato e suas consequências. $\mathrm{O}$ autor afirma que a intenção em padronizar a produção de vinho e centralizar as atividades vitivinícolas seria de construir uma indústria capitalista de vinicultura, que até então, era dominada pelo artesanato doméstico ou pelos pequenos comerciantes. O autor fala ainda que a obrigatoriedade de venda exclusiva dos associados para o sindicato e a proibição do fabrico de vinhos nos porões das casas são ações que culminam em "solapar as condições básicas do artesanato doméstico dos vinhos". Na pesquisa de campo realizada foi 
possível notar que os produtores de vinho em geral da região, são avessos à padronização dos vinhos. O enoturista-pesquisador ouviu de vários produtores a expressão "vinho coca-cola" quando se referiam de alguns vinhos chilenos que são industrializados e padronizados em demasia. Com relação aos porões de produção de vinhos, é notório que os produtores que tem suas cantinas sob suas casas tratam delas com muita atenção e orgulho. Muitos produtores visitados que ainda tem cantina sob a casa citam, até com certo orgulho, que em tempos passados foi proibido que houvesse cantinas em baixo das casas.

O autor trata da relação camponês-indústria como "a relação fundamental do camponês com o mercado capitalista". Essa questão ocorre quando o agricultor vende suas uvas para a indústria, e desta forma tem seu trabalho explorado pela indústria. As estratégias de dominação da indústria que o autor elenca são as mesmas queixas que os produtores atuais fazem, como o fato de as indústrias pagarem pouco, na maioria das vezes valores inferiores ao valor mínimo estipulado pela Conab; os acordos de exclusividade com as indústrias, ficando impossibilitados de vender uvas para outras entidades que não a acordada; o tempo que os produtores demoram para receber a remuneração da venda da uva, esse ponto será detalhado posteriormente pois além de ser criticado no livro, é unânime entre todos os produtores atuais; pelo critério subjetivo de avaliação, classificação e consequentemente a remuneração pelas uvas; e finalmente na forma de pressionar os produtores a "entregar as uvas" e não reclamarem dos preços.

A questão do Cooperativismo, apesar de ser tratado consensualmente como algo que traz benefícios aos cooperados, quando se trata de cooperativas no segmento vitivinícola deve ser tratado com muita cautela, principalmente na região do Vale dos Vinhedos. No livro dos colonos do vinho, o autor aponta que as cooperativas vinícolas da região trabalham sob a mesma dinâmica das empresas privadas, tanto na questão da compra das uvas como na questão da tendência ao oligopsônio, que é quando existe um único comprador para vários produtores/fornecedores. $\mathrm{O}$ autor demonstra a afirmação sobre o pequeno número de compradores de uva quando afirma que $68 \%$ da uva vinificada era vendida para cinco cooperativas, dentre essas, duas cooperativas detinham mais de $50 \%$ das uvas vinificadas no estado gaúcho no ano de 1972, demostrando que o produtor tinha dificuldades para vender suas uvas até mesmo para as cooperativas. $\mathrm{O}$ autor aponta que a partir do momento que a cooperativa compra a uva do produtor, ela está compactuando com a exploração do trabalho do camponês e competindo com a fabricação do vinho artesanal. Conforme as palavras do autor "Tudo leva a concluir que as Cooperativas realizaram, tal como as empresas, o processo de destruir a fabricação doméstica do vinho e de construir a indústria do vinho na região" (p. 117). 
$\mathrm{Na}$ atualidade os produtores passam por uma situação parecida, no entanto, talvez um pouco mais crítica. No passado havia algumas indústrias e cooperativas que compravam as uvas dos produtores. Atualmente existe uma grande empresa, a Tecnovin, que de certa forma, compra as uvas de todos os pequenos produtores da região.

A antiga Cooperativa Aurora se extinguiu deixando um saldo devedor para que os cooperados honrassem a dívida. Os produtores dizem que, nos últimos anos da cooperativa Aurora quase todos que eram associados, e todos os associados "herdaram a dívida" da cooperativa. O produtor Pedro Valiatti confirma que "herdou" uma dívida de $\mathrm{R} \$ 80.000,00$ que vem pagando até hoje. Sendo assim, pode-se inferir que a situação dos produtores do Vale dos Vinhedos no tocante à venda das uvas e assistência de cooperativas está mais frágil atualmente que no passado, em 1973, quando analisado por José Vicente dos Santos.

Com relação às questões de convívio entre os habitantes da região do Vale dos Vinhedos, podem ser vistas algumas similaridades entre a atualidade e o período de análise do livro. No livro o autor cita que as relações entre os habitantes eram feitas de maneira bastante horizontal e sem grandes distinções sociais entre os habitantes da região. O autor explica que isso se dava principalmente por serem em sua maioria proprietários de pequenas propriedades, serem descendentes de imigrantes italianos e as famílias se conhecerem.

Pode-se notar que, de maneira geral, as relações entre os habitantes da região mantiveram-se parecidas, pois em conversa com o produtor Cesar Petrolli, um dos donos da vinícola Barcarola, este havia dito que ainda hoje os habitantes da região do Vale dos Vinhedos se conhecem, pois as famílias dos imigrantes acabaram se misturando.

Com relação às festividades tratadas no livro, é possível ver algumas semelhanças nas festividades realizadas na atualidade, como foi o caso presenciado do festival do vinho colonial. O autor cita que em períodos que a parreira demanda menos atenção são realizadas as festividades dos colonos. Os Serões são as festas feitas pelos colonos que normalmente ocorrem das vinte até as vinte e três horas, onde são feitos filós. Segundo o autor, filó é a reunião dos produtores onde "contam estórias, falam de negócios da uva e do vinho, às vezes cantam músicas tradicionais dos imigrantes italianos, sempre falando em dialeto de Vêneto".

Durante o festival do vinho colonial, foram observadas as mesmas práticas sociais descritas pelo autor. O festival teve sua realização para o início do mês de setembro, período marcado pelo fim do período das podas e amarração das videiras. No festival do vinho colonial, apesar de não ser o foco do evento, notou-se que os produtores se agrupavam para fazer o filó 
da mesma forma descrita por Santos e a música italiana era cantada pelo coral de produtores e pelos frequentadores. Com relação às pessoas conversarem no dialeto de Vêneto, foi percebido que com o passar da festa, algumas pessoas começaram a falar em outra língua, que o enoturistapesquisador identificou como italiano.

A proximidade entre o Serão de antigamente e o festival do vinho colonial ocorre até mesmo no horário de realização, como foi dito anteriormente pelo autor, os serões tinham início às $20 \mathrm{H}$ e terminavam às $23 \mathrm{H}$. Por sua vez, o festival teve seu início programado para as 19:30 $\mathrm{H}$, como pode ser visto na foto do convite do festival, e teve seu final próximo da meia noite.

A facilidade que os colonos tem para se agrupar vai muito além dos motivos de festividades. $\mathrm{O}$ autor trata que os colonos tem o hábito de se juntarem para fazer os mais variados tipos de trabalho, desde ajudar outros colonos em tarefas que demandam mais braços, como se organizarem para pleitear e negociar com o Estado. Segundo as palavras do autor, "a consciência política entre os camponeses oscila entre uma expectativa da ação paternalista por parte do Estado e a emergência de uma consciência sindical” (p. 165). O autor cita a frase de um colono onde mostra a legitimidade que o Estado tem para ele: "Pra mim o governo é uma coisa muito importante, pra nois, ele ajuda o produtor em muita coisa" (p 167). Se por um lado o colono na época da pesquisa do livro esperava e demandava a intervenção do Estado, atualmente os produtores coloniais tem muita descrença com as ações do Estado. Na atual pesquisa feita com os produtores coloniais da região do Vale dos Vinhedos, era muito frequente ouvir críticas às ações do governo e suas intervenções, principalmente na questão tributária.

Aparentemente de maneira contraditória, os colonos da atualidade se mostraram unidos, pois ainda mantém algumas das reuniões tradicionais de produtores. Os produtores se uniram e dividiram tarefas para antes e depois da realização do festival do vinho colonial. No dia posterior ao festival, o enoturista-pesquisador foi junto com um dos produtores para ajudar a limpar o galpão onde foi realizado o evento.

É notório que os produtores se comunicam frequentemente, mas em conversa com alguns produtores, eles alegaram que uma ação da comunidade que poderia melhorar a realidade não só dos produtores coloniais, mas de todos os habitantes da região seria que a comunidade fosse mais unida. $\mathrm{O}$ produtor Rui Todeschini afirma que se a comunidade fosse mais unida, $\mathrm{o}$ Vale seria bem melhor. 
Com relação à presença e função do estado, foi possível notar similaridades e diferenças com o descrito no texto. $\mathrm{O}$ autor cita que alguns produtores apoiaram a intervenção do Estado na vitivinicultura, nas palavras do agricultor entrevistado:

“Este governo aqui endireitô muito. Obrigô a cantina, foi lá, non dexava mais fazê vinho com água. Se comprava vinho com água, ele soltava fora na estrada com caminhon carregado. Se tinha água, enton ele obrigô a fazê vinho com uva, non com água"(SANTOS, 1984, p. 166).

Mais de trinta anos se passaram e as críticas dos produtores ainda são muito parecidas, como é o caso da crítica feita pelo produtor Maikon Panizzi, que cita que algumas cantinas industriais e até alguns produtores de vinho colonial colocam água no vinho. Ele explica que colocam água no vinho tanto com o intuito de render mais, como para manter as pipas sempre cheias, pois as pipas/barris de madeira inevitavelmente acabam absorvendo parte do vinho.

Com ar de descontração, o produtor Maikon Panizzi afirmou que "antigamente Jesus transformou água em vinho, hoje em dia tem gente transformando o vinho em água!”. Da mesma forma que o produtor Maikon Panizzi cobrou a presença do Estado na Viticultura, o produtor Mateus Dalla Corte disse que algumas das grandes vinícolas usam a indicação geográfica do Vale dos Vinhedos em toda sua produção, no entanto muitos dos outros campos de produção de uvas são fora e às vezes bem distantes do Vale. Mateus afirma que isso deveria ser fiscalizado e isso não deveria ser permitido.

O autor trata que os colonos aprenderam que só tem força para cobrar algo do Estado ou da indústria coletivamente. No período da pesquisa do livro, os produtores encontravam nos sindicatos a forma de se unirem para ter tal força. $\mathrm{O}$ autor evidencia que inicialmente os pleitos dos produtores coloniais estavam mais ligados às questões mais imediatas à vida dos produtores. No entanto, o autor pondera que essa força coletiva dos colonos pode gerar o desenvolvimento de processos com a presença de novas formas de participação política dos camponeses na sociedade capitalista.

Desta forma exposta pelo autor, é possível inferir que o embrião da lei dos vinhos coloniais é uma das formas de aumentar a participação política da causa camponesa em nossa sociedade capitalista, conforme afirmação anterior do autor.

Outra ponderação possível de ser feita a partir da leitura e interpretação do livro, somado com a atual experiência com os vitivinicultores coloniais do Vale dos Vinhedos, é o fato que a fabricação de vinho colonial pelos agricultores é antes de tudo uma ação de resistência. Trata- 
se de um movimento de resistência cultural e de afirmação da identidade daquela comunidade, um movimento de resistência à exploração do trabalho do agricultor pela indústria e uma forma de resistência à contribuição e subordinação ao Estado.

Da maneira que o livro e os agricultores visitados expõem suas ideias e intenções, é possível confirmar a hipótese dada neste trabalho que os trabalhadores coloniais trabalham de tal forma que rompem, pelo menos em parte com a dinâmica capitalista, como trata o autor José Vicente dos Santos, ou como foi sugerido pelo enoturista-pesquisador, exercem seu trabalho de maneira pré-revolução industrial. É importante atentar que não é intenção deste trabalho criticar a dinâmica capitalista ou pós-industrial, mas, somente, demostrar que ainda existem algumas formas de resistência a tais dinâmicas.

Da forma que o agricultor colonial trabalha e faz seus vinhos é possível atestar sua condição de resistente a tais dinâmicas, no entanto, é possível inferir que tal resistência não perdurará por muito tempo, pois a questão fulcral da resistência do trabalho colonial está na forma como o colono trabalha.

Na pesquisa de campo ficou claro que os produtores coloniais estão diminuindo, pois na fala da maioria dos vitivinicultores coloniais: "os jovens não querem continuar o trabalho sob a parreira".

No entanto, as perspectivas sobre a região do Vale dos Vinhedos e a produção de vinhos coloniais não é consensual entre os produtores. Se por um lado temos produtores mais velhos e descrentes com o futuro da produção de vinhos coloniais e com o futuro da região do Vale dos Vinhedos, temos todos os jovens produtores, que de fato são poucos, bastante confiantes e otimistas sobre os mesmos aspectos.

\section{CAPÍTULO 4: CONSIDERAÇÕES FINAIS SOBRE A PESQUISA}

Pelas visitas feitas com os produtores de vinho colonial que estavam expondo no segundo festival do vinho colonial no Vale dos Vinhedos, foi possível identificar aspectos que até então a literatura pouco tratava. No entanto, isso não significa dizer que tais afirmações sejam inéditas, até porque tais novos aspectos são ponderações do senso comum entre os produtores de vinho colonial, só até então pouco abordada nos estudos daquela região.

Todos os produtores de vinho colonial entrevistados tem conhecimento da importância do turismo para a região, mesmo não sendo unânime a intenção de investir no enoturismo. A 
maioria dos produtores entrevistados disseram que tem interesse em investir no turismo da propriedade. Somente dois produtores, dos 14 produtores entrevistados, alegaram não ter interesse em investir no enoturismo colonial em suas propriedades.

Como todos os produtores de vinho colonial vendem a maior parte da sua produção de uvas para a indústria de vinhos e sucos e a menor parcela é reservada para a fabricação de vinhos coloniais, quando questionados quais seriam as ações que ajudariam os produtores da região, dentre as várias ações citadas por cada produtor, a questão de melhor remunerar os produtores pela venda das uvas é consensual. Os produtores consideram que melhorar a remuneração das uvas não está somente atrelado ao aumento do valor pago pela uva, mas também ao fato do longo período entre a entrega da uva e o pagamento referente à venda.

Outra questão consensual entre os produtores é que a lei do vinho colonial, da forma como foi aprovada, com a taxação de imposto igualitária com os vinhos comerciais, não ajudou em nada os produtores. Os produtores disseram estar decepcionados, como na fala de um dos produtores, foi "um verdadeiro balde de água fria". Os produtores não se sentiram representados nem apoiados pela forma como a lei foi aprovada. Basicamente o discurso de todos os produtores girava em torno de que se a lei não os apoia em nenhum aspecto, então eles irão continuar a produzir e comercializar seus vinhos coloniais da mesma forma que era feita antes da aprovação da lei. Segundo informações dos próprios produtores e técnicos da Emater local, nenhum produtor aderiu à lei dos vinhos coloniais.

Quando questionados sobre quais seriam as ações que poderiam resolver o entrave da alta taxação de impostos sobre o vinho colonial, a resposta dada pela maioria dos produtores de vinho colonial era a mesma: reformular a lei que impossibilita o comércio dos vinhos com o talão do produtor rural.

Os produtores coloniais apontaram uma possível mudança da lei, que segundos eles, geraria de fato benefícios para os pequenos produtores coloniais. Parte dos produtores apoiam a ideia de que o limite de 20.000 litros estipulados pela lei fosse baixado para 10.000 litros de vinhos colonial e que esse volume fosse permitido a comercialização por meio do talão do produtor rural. A maioria dos produtores visitados disseram produzir uma quantidade bem inferior ao limite adotado em lei. O volume de vinho produzido pelos produtores visitados varia de 2.000 a 20.000 litros, obtendo uma média de produção de aproximadamente 9.500 litros de vinho por ano. 
O êxodo rural dos jovens é uma realidade nacional e na região do Vale dos Vinhedos, pelo que foi observado, não é diferente. A grande maioria dos produtores de vinhos coloniais já passam dos 50 anos de idade e se preocupam com o futuro da propriedade, dos filhos e do Vale dos Vinhedos. Se por um lado os produtores mais velhos tem um grande apego pela terra, como afirmou um dos produtores, os filhos desses produtores não tem o mesmo apego pela propriedade e pelo trabalho na terra. A socióloga e extensionista da Emater, cita que essa realidade já preocupa a região e cita alguns casos conhecidos da região onde alguns filhos já sinalizaram ter interesse em permanecer com os trabalhos na propriedade, mas esses jovens são a exceção. Vários produtores entrevistados disseram que estão preocupados com o futuro da região, pois assim como os seus filhos, os filhos dos seus vizinhos também não tem interesse em permanecer com a propriedade e com os trabalhos rurais.

É notório que os produtores mais jovens tem uma visão diferente dos mais velhos, e acreditam que o Vale dos Vinhedos e os vinhos coloniais tendem a se desenvolver ainda mais. Todos os produtores jovens disseram ter interesse em investir no enoturismo colonial. É interessante notar que os jovens vitivinicultores coloniais buscam alternativas para poder se diferenciar e desenvolver o enoturismo colonial. As estratégias são diversas, desde a construção de cantinas novas e pintura de barris de vinho, produção de uvas europeias e a confecção de um mapa do enoturismo colonial na região do Vale dos Vinhedos.

Foi possível observar que o enoturismo colonial é oficialmente inexistente, existindo apenas sob a condição da informalidade. O vinho colonial é uma realidade onde todos da região tem conhecimento da existência, já o enoturismo colonial é ainda desconhecido pelos próprios habitantes da região, demostrando que o enoturismo colonial é ainda mais informal e desconhecido que a própria produção e comercialização informal de vinhos coloniais.

O cenário do vinho colonial no Vale dos Vinhedos merece atenção pois, mesmo que os produtores mais velhos vendam suas propriedades para os jovens produtores de vinho colonial, ainda assim haverá uma diminuição da elaboração e oferta dos vinhos coloniais. Como todos os produtores de vinho colonial vendem a maior parte de sua produção de uvas para a indústria e uma pequena parte é reservada para o fabrico do vinho artesanal, caso o jovem produtor tenha uma maior área, a tendência será dele continuar a vender a maior parte de sua produção e guardar aproximadamente a mesma quantidade que reservava antes de ter sua área ampliada.

Nota-se que a produção de vinho colonial é diretamente relacionada com o número de produtores e não com a área cultivada. É possível notar isso pois os pequenos produtores tem 
uma capacidade limitada de equipamentos para a elaboração do vinho; a reserva feita à priori é relacionada com o número de pessoas da família que irão beber o vinho, que nessas condições se mantem constantes. É bastante razoável pensar que quanto maior se tornarem as propriedades, menos produtores haverão na região, logo, menos vinhos coloniais serão produzidos e mais uvas serão vendidas para as indústrias.

Outro fator que demostra a importância do vinho colonial, principalmente para os estudiosos, é a questão da parcial resistência à exploração dos vitivinicultores pela Indústria e pelo Estado, fazendo assim uma forma de produção aos modos pré-revolução industrial ou, como o autor Vicente Tavares descreve, personagens não especificamente capitalistas.

Desta forma, é possível considerar que a produção e comercialização do vinho colonial é mais do que um fato muito importante, é uma realidade, para os vitivinicultores da região, pois, o vinho colonial atua para aquela comunidade como forma de identificação, expressão cultural, valorização histórica e resistência social. Já o enoturismo colonial, apesar de ser feito em caráter totalmente informal e tímido, pode apresentar-se como uma confirmação e legitimação de todos os aspectos abordados pelo vinho colonial.

\section{REFERÊNCIAS BIBLIOGRÁFICAS}

ACHUTTI, Luiz Eduardo. Fotoetnografia: Um estudo de antropologia visual sobre cotidiano, lixo e trabalho em uma vila popular na cidade de Porto Alegre. Editora TOMO: Porto Alegre, 1996.

ADEGABRASIL. Curso de Vinho para hot Site do Clube do Vinho. modulo 5/Abril de 2011. Disponível em: <http://www.adegabrasil.com/adega/clube/pdf/modulo5.pdf >. Acesso em: 23 de agosto de 2014.

AGROSTAT. Ministério da agricultura pecuária e abastecimento. Disponível em: <www.mapa.gov.br>. Acesso em: 03 de agosto de 2014. 
APROVAlE: Portal da Associação dos Produtores de vinhos finos do Vale dos Vinhedos

http://www.valedosvinhedos.com.br/vale/conteudo.php?view=98\&idpai=132\#null $>$. Acesso em: 28/05/2015.

BARHAM, Elizabeth. Translating terroir: the global challenge of French AOC labeling. USA Journal of Rural Studies 127-138. Department of Rural Sociology, University of Missouri, Sociology Building, Columbia, 2003.

BENTO GONÇALVES': Município de Bento Gonçalves/FESTIVAL NACIONAL

DO VINHO COLONIAL. Disponível em: <http://www.bentogoncalves.rs.gov.br/acidade/feiras-e-eventos/festival-nacional-do-vinho-colonial-gastronomia-vinho-e-alegria-2> Acesso em: 07 de jul de 2014.

BENTO GONÇALVES²: Município de Bento Gonçalves/VINHOS COLONIAIS. Disponível em: <http://www.bentogoncalves.rs.gov.br/noticia/vinhos-coloniais-sao-avaliadospor-enologos> Acesso em: 22 de jul de 2014.

BRASIL. Lei $n^{\circ}$ 12.959/2014 (Lei dos vinhos coloniais). Disponível em: <http://www.planalto.gov.br/ccivil_03/_Ato2011-2014/2014/Lei/L12959.htm>. Acesso em: 25 de jun de 2014

BRASIL. Lei $\mathbf{n}^{\circ}$ 9.279/1996 (Lei de Propriedade Intelectual). Disponível em: <http://www.planalto.gov.br/ccivil_03/leis/19279.htm> Acesso em: 25 de fev de 2014.

BRASIL. Mensagem de veto da lei $n^{\circ}$ 12.959/2014. Disponível em: http://www.planalto.gov.br/ccivil_03/_Ato2011-2014/2014/Msg/VEP-45.htm acesso em 25 de jun de 2014.

BLOGSPOT. O cultivo e enxertia da videira: disponível em: <http://sereisumasocarne.blogspot.com.br/2012/06/o-cultivo-e-o-enxerto-na-videira.html>. Acesso em: 21 de agosto de 2014.

BONI, P. C.; MORESCHI, B. M. Fotoetnografia: a importância da fotografia para o resgate etnográfico. Doc On-line, n.3, p. 137-157, dez. 2007.

BRUNCH, KELLY. Análise da tributação incidente na cadeia produtiva do vinho brasileiro. XLIII CONGRESSO DA SOBER- Sociedade Brasileira de Economia e Sociologia Rural. São Paulo, 2005.

CARRARO, Miguel: HISTÓRIA DO ENOTURISMO NA SERRA GAÚCHA: Análise dos municípios de Bento Gonçalves, Caxias do Sul, Flores da Cunha, Garibaldi e 
Veranópolis - 1910 a 1995. FACULDADE DE INTEGRAÇÃO DO ENSINO SUPERIOR DO CONE SUL - FISUL. Garibaldi, 2008.

CAVICCHIOLI, Marina. O terroir e a identidade cultural. Terroir, vinho e identidade: uma equação que tem tudo a ver com a diversidade cultural da humanidade. Revista Adega, $10^{\circ}$ edição, 2006.

CEREJA, Lis. Para entender de vinhos. Editora Saraiva, 2010.

CONAVINHO -Congresso Nacional de Apreciadores de Vinhos. Disponível em: www.conavinho.com.br. Acesso do dia 04 de agosto até 15 de agosto de 2014.

CRESWEEL, John W. Projeto de Pesquisa: métodos qualitativos, quantitativos e misto. Tradução Luciana de Oliveira da Rocha. $2^{\circ}$ Edição, Porto Alegre: Editora Artmed, 2007.

DAHER, Thiago Gabriel. A Importância da Historia Oral para o enoturismo, Anais do I Simpósio de Metodologia da História e IX Encontro Regional Centro-Oeste da Associação Brasileira de História Oral: a polissemia nas cidades, História Oral centro oeste, 2013.

DALCIN, Maria Stefani. Vale dos Vinhedos: História e vida. Bento Gonçalves; Gráfica Pallotti, 2008.

DALLANHOL, Eliza; TONINI, Hernanda. Enoturismo -Série Turismo. São Paulo: Editora Aleph, 2012.

DELGADO, Lucilia. História oral: memória, tempo, identidades. Belo Horizonte, 2010 .

DEMO, Pedro. Metodologia do Conhecimento Científico. $1^{\circ}$ Edição, São Paulo: Atlas, 2000.

DRUGEON, Philippe. Contribution critique à l'étude des saviors et des savoir-faire viticoles liés à la typicité du terroir Chargé de mission en sociologie - Unité Mixte de Recherche Vinitera -Angers, Février. 2009.

ELIAS, Norbert. O processo civilizador. Rio de Janeiro: Jorge Zahar Ed., vol 2, 1994.

EMBRAPA. Embrapa pelo Brasil. Disponível em: https://www.embrapa.br/embrapano-brasil. Acesso em: 28/11/2014.

EMBRAPA. Uva e vinho. Vale dos Vinhedos Disponível em: http://www.cnpuv.embrapa.br/tecnologias/ig/valedosvinhedos.html. Acesso em: 28/05/2015. 
EMBRAPA. Uvas Viníferas para Processamento em Regiões de Clima Temperado. Embrapa Uva e Vinho. Sistema de Produção, 4. ISSN 1678-8761 Versão Eletrônica, Jul./2003.

ENGELS, Friedrich.(1895) A origem da família da propriedade privada e do Estado. $2^{\circ}$ edição, São Paulo: Expressão popular, 2010.

FALCADE, Ivanira. O espaço geográfico e o turismo na Região da Uva e do Vinho no nordeste do Rio Grande do Sul. In: Encontro Estadual de Geografia, 21; Caxias do Sul: EDUCS, 2001. Anais. Caxias do Sul: Educs, 2001.

FLORES, C. et al. Os solos do Vale dos Vinhedos. ISBN 978-85-7035-157-9. Brasília: Embrapa, 2012. 176 p.

GLASS, ROGÉRIO FABRÍCIO. As indicações geográficas como estratégia mercadológica para vinhos. Brasília, DF: Embrapa Informação Tecnológica, 113 p, 2009.

GIDDENS, Anthony. Sociologia. Fundação Calouste Gulbenkian, $6^{\circ}$ edição, 2008.

GOLLO, SILVANA. Inovação e estratégia de cooperação competitiva:estudo de caso da indicação de procedência Vale dos Vinhedos- Serra Gaúcha/RS. Porto Alegre, 2006.

HALL, Stuart. A identidade cultural na pós-modernidade. Tradução Tomaz Tadeu da Silva, Guaracira Lopes Louro - 11 edição, Rio de janeiro: DP\&A, 2006.

INPI- Instituto Nacional de Propriedade Intelectual. Disponível em: <http://www.inpi.gov.br/portal/artigo/guia_basico_indicacao_geografica>. Acesso em: 16 de jan de 2014.

LAVANDOSKI, Joice et al. Uva, vinho e identidade cultural na Serra Gaúcha (RS, Brasil). Revista Brasileira de Pesquisa em Turismo. São Paulo, 6(2), pp. 216-232, mai./ago. 2012.

ORTIZ, Renato. Cultura Brasileira e identidade nacional. $5^{\circ}$ edição, São Paulo, 2006. Pag.31-32.

PEBAYLE, Raymond. Os viticultores do Rio Grande do Sul [Parte 1]. Boletim geográfico do Rio Grande do Sul, n 16, p. 51-64, 1973. 
PORTAL GUARANY. Imagem de atomizador costal. Disponível em: $<$ http://www.guaranyind.com.br/equipamentos/agricultura-e-horticultura/atomizador-costalmotorizado-111/ >. Acesso em: 18 de out de 2014.

ROD PHILLIPS. Uma breve história do vinho; Tradução de Gabriel Máximo $3^{\circ}$ ed. Rio de Janeiro: Record, 2005.

SANTOS, JOSE VICENTE. Colonos do Vinho: Estudo sobre a subordinação do trabalho camponês ao capital. Segunda Edição, editora HUCITEC. São Paulo, 1984.

SELTON, PHILIP, O mais completo guia sobre vinhos. São Paulo: Mandarim, 2001.

SOARES, HIVÂNIA. Vinho e hospitalidade no Vale dos Vinhedos. São Paulo, 2004.

SOUZA, Flávio. Mudança promovida no setor vitivinícola do Rio Grande do Sul pela inserção de profissionais especializados nas áreas de viticultura e enologia. Universidade Federal Rural do Rio de Janeiro- Decanato de pesquisa e pós-graduação em educação agrícola, Rio de Janeiro, 2005.

THOREAU, Henry. A desobediência civil. Porto Alegre, Editora L\&PM, 1997.

TRENTINI, FLAVIA. Denominações de origem: aplicação do princípio do desenvolvimento sustentável na agricultura. USP, São Paulo, 2009.

TONIETTO, Jorge. Experiências de desenvolvimento de indicações geográficas: vinhos da indicação de procedência Vale dos Vinhedos. In valorização de produtos com diferenciação de qualidade e identidade: Indicações Geográficas e certificações para competitividade nos negócios. Brasília, SEBRAE, 2005.

TONIETTO, Jorge. Afinal, o que é Terroir? Flores da Cunha-RS, v. 8, n. 98, p. 08, abr. 2007.

TONINI, Hernanda; MACKE, Janaina. Confiança e Capital Social para o Desenvolvimento de comunidades rurais: Caso da Aprovale-Revista de gestão social e ambiental, 2007.

VALDUGA, Vander. $O$ uso da identidade como estratégia competitiva: $O$ caso da vitivinicultura da região uva e vinho - RS, 2008.

VALDUGA, Vander. Sobre Enocultura. In: Paula Nora; Bianca Pugen. (Org.). Diálogos. $1^{\circ}$ ed.Caxias do Sul: Lorigraf, 2008, v. , p. 65-79 
VALDUGA, Vander. O PROCESSO DE DESENVOLVIMENTO DO ENOTURISMO NO VALE DOS VINHEDOS. Universidade de Caxias do Sul programa de pós-graduação em turismo. Caxias do Sul, 2007.

VINHO FORTALEZA. Imagem de Indicação Geográfica Vale dos Vinhedos: Disponível em: vinhofortaleza.blogspot.com.br. Acesso em: 20/10/2014

ZANINI, Maria Catarina Chitolina. UM OLHAR ANTROPOLÓGICO SOBRE FATOS E MEMÓRIAS DA IMIGRAÇÃO ITALIANA. MANA 13(2): 521-547, 2007

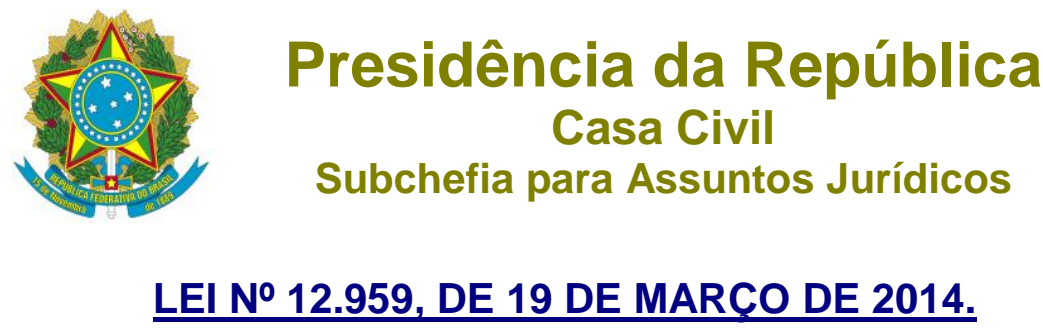

Altera a Lei no 7.678 , de 8 de novembro de 1988, para tipificar o vinho produzido por agricultor familiar ou empreendedor familiar rural, estabelecer requisitos e limites para a sua produção e comercialização e definir diretrizes para o registro e a fiscalização do estabelecimento produtor. 
A PRESIDENTA DA REPÚBLICA Faço saber que o Congresso Nacional decreta e eu sanciono a seguinte Lei: 2o-A:

Art. 10 A Lei no 7.678 , de 8 de novembro de 1988, passa a vigorar acrescida do seguinte art.

"Art. $2^{\circ}$-A. O vinho produzido por agricultor familiar ou empreendedor familiar rural é a bebida elaborada de acordo com as características culturais, históricas e sociais da vitivinicultura desenvolvida por aquele que atenda às condições da Lei no 11.326, de 24 de julho de 2006, observados os requisitos e limites estabelecidos nesta Lei.

$\S 1$ O vinho produzido por agricultor familiar ou empreendedor familiar rural deve ser elaborado com o mínimo de $70 \%$ (setenta por cento) de uvas colhidas no imóvel rural do agricultor familiar e na quantidade máxima de 20.000 I (vinte mil litros) anuais.

§ 2o A elaboração, a padronização e o envasilhamento do vinho produzido por agricultor familiar ou empreendedor familiar rural devem ser feitos exclusivamente no imóvel rural do agricultor familiar, adotando-se os preceitos das Boas Práticas de Fabricação e sob a supervisão de responsável técnico habilitado.

§ 3o A comercialização do vinho produzido por agricultor familiar ou empreendedor familiar rural deverá ser realizada diretamente com o consumidor final, na sede do imóvel rural onde foi produzido, em estabelecimento mantido por associação ou cooperativa de produtores rurais ou em feiras da agricultura familiar.

$\S 4$ - Deverão constar do rótulo do vinho de que trata o caput deste artigo:

I - a denominação de "vinho produzido por agricultor familiar ou empreendedor familiar rural", "vinho colonial" ou "produto colonial";

II - a indicação do agricultor familiar ou empreendedor familiar rural, com endereço do imóvel rural onde foi produzido;

III - o número da Declaração de Aptidão ao Programa de Fortalecimento da Agricultura Familiar - DAP fornecida por entidade autorizada pelo Ministério do Desenvolvimento Agrário MDA;

IV - outras informações exigidas ou autorizadas nesta Lei e em seus regulamentos.

§ 5o (VETADO)."

Art. 2 o $\mathrm{O}$ art. 27 da Lei ำ 7.678, de 8 de novembro de 1988, passa a vigorar acrescido do § 2 , renumerando-se 0 atual parágrafo único para $\S 1$ :

"Art. 27.

$\S 1$ 으

$\S 2^{\circ}$ O registro de estabelecimento produtor de vinho produzido por agricultor familiar ou empreendedor familiar rural fica condicionado a comprovação periódica dos requisitos estabelecidos no art. 2--A desta Lei." (NR) redação:

Art. 3o $O$ art. 43 da Lei o 7.678 , de 8 de novembro de 1988, passa a vigorar com a seguinte 
"Art. 43. O registro do estabelecimento e do produto, a classificação, o controle, a inspeção e a fiscalização do vinho e dos derivados da uva e do vinho sob os aspectos higiênico-sanitários e de qualidade serão executados em conformidade com as normas e prescrições estabelecidas nesta Lei e em seu regulamento.

$\S 10$ As exigências para o registro de estabelecimento produtor de vinho produzido por agricultor famiAliar ou empreendedor familiar rural deverão ser adequadas às dimensões e finalidades do empreendimento, e seus procedimentos deverão ser simplificados.

§ 2ㅇ A inspeção e a fiscalização da elaboração do vinho produzido por agricultor familiar ou empreendedor familiar rural deverão ter natureza prioritariamente orientadora, observando-se o critério de dupla visita para lavratura de autos de infração." (NR)

Art. 4 Esta Lei entra em vigor na data de sua publicação.

Brasília, 19 de março de 2014; 193ㅇ da Independência e 126으 da República.

DILMA ROUSSEFF

Guido Mantega

Neri Geller

Este texto não substitui o publicado no DOU de 20.2.2014

\section{ANEXO B: MENSAGEM DE VETO DADA À LEI}

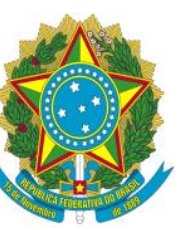

Presidência

da

República

Casa

Civil

Subchefia para Assuntos Jurídicos

MENSAGEM Nº 45, DE 19 DE MARÇO DE 2014.

Senhor Presidente do Senado Federal, 
Comunico a Vossa Excelência que, nos termos do $§ 1^{\circ}$ do art. 66 da Constituição, decidi vetar parcialmente, por contrariedade ao interesse público, o Projeto de Lei ${ }^{\circ} 110$, de $2013\left(\mathrm{n}^{\circ}\right.$ 2.693/11 na Câmara dos Deputados), que “Altera a Lei $\mathrm{n}^{\circ}$ 7.678, de 8 de novembro de 1988, para tipificar o vinho produzido por agricultor familiar ou empreendedor familiar rural, estabelecer requisitos e limites para a sua produção e comercialização e definir diretrizes para o registro e a fiscalização do estabelecimento produtor”.

Ouvido, o Ministério da Fazenda manifestou-se pelo veto ao seguinte dispositivo:

$\S 5^{\circ}$ do art. $2^{\circ}$-A da Lei $n^{\circ} 7.678$, de 8 de novembro de 1988 , inserido pelo art. $1^{\circ}$ do projeto de lei

"§ $5^{\circ}$ A comercialização de vinho colonial será realizada por meio de emissão de nota do talão de produtor rural e exigirá em sua rotulagem a especificação de sua denominação, origem e características do produto."

Razão do veto

“A determinação da comercialização de vinho colonial por meio de nota do talão de produtor rural pode ser interpretada como desobrigação da emissão de nota fiscal, necessária na sistemática de arrecadação do Imposto sobre Produtos Industrializados - IPI.”

Essa, Senhor Presidente, a razão que me levou a vetar o dispositivo acima mencionado do projeto em causa, a qual ora submeto à elevada apreciação dos Senhores Membros do Congresso Nacional.

Este texto não substitui o publicado no DOU de 20.3.2014 